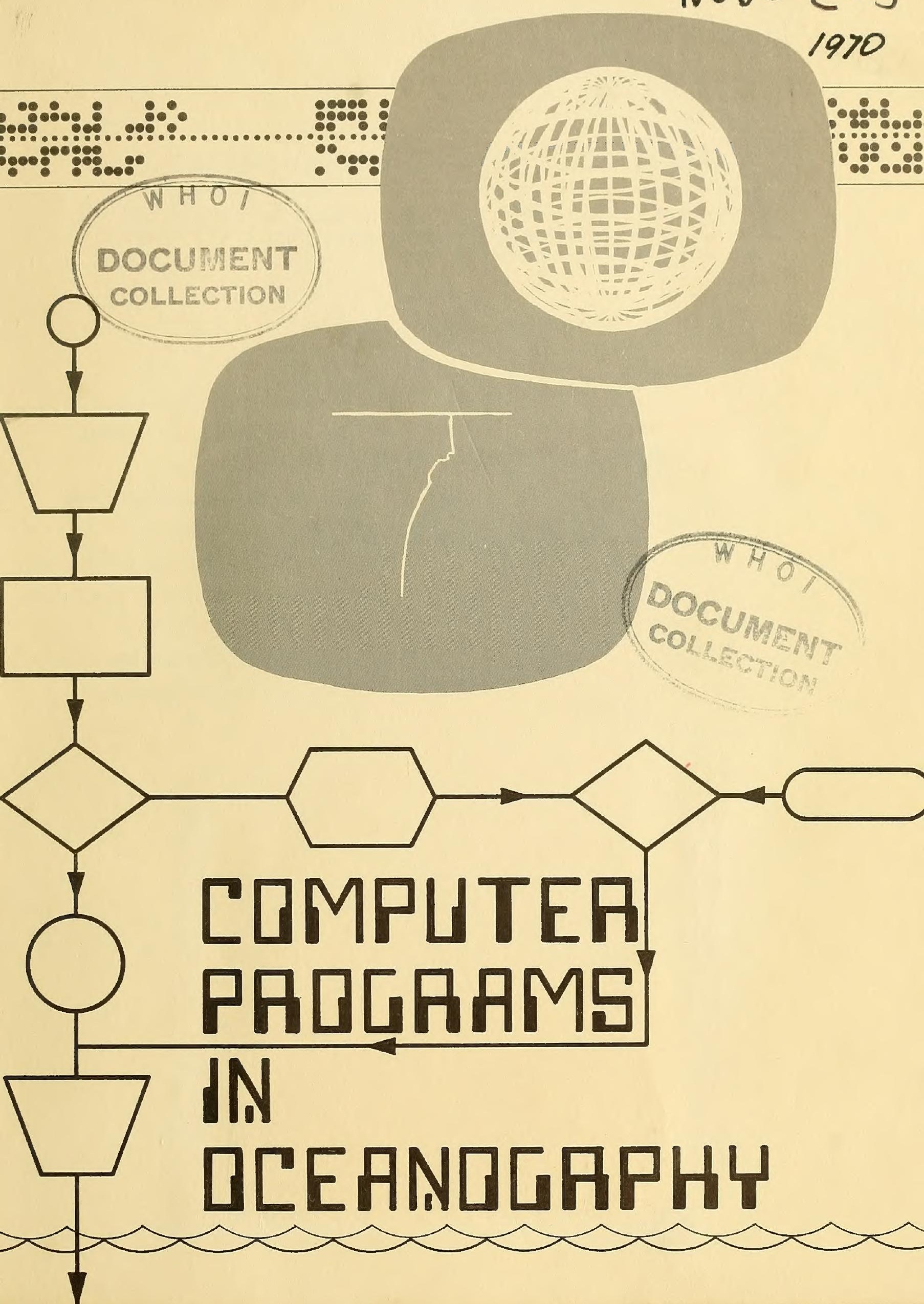


The National Oceanographic Data Center is sponsored by U.S. Government agencies having an interest in the marine environment; it is governed by an Advisory Board composed of representatives of these activities and the National Academy of Sciences. The U.S. Naval Oceanographic Office is assigned responsibility for management of the National Oceanographic Data Center.

The Sponsoring Agencies are:

Atomic Energy Commission

Bureau of Commercial Fisheries

Coast Guard

Coastal Engineering Research Center

Department of the Navy

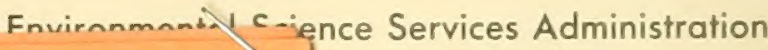

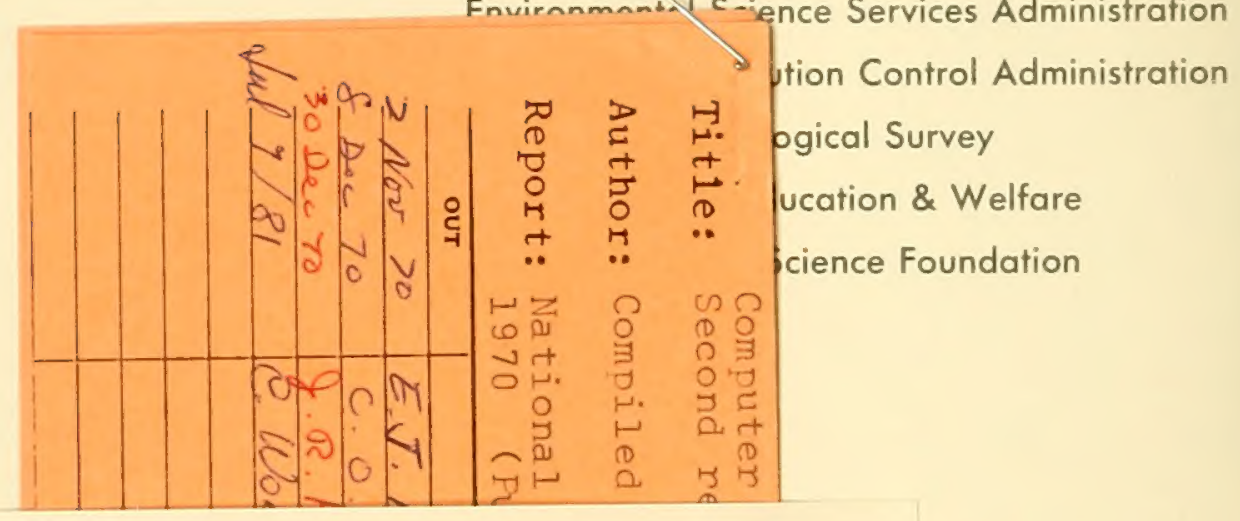


NATIONAL OCEANOGRAPHIC DATA CENTER

CATALOG SERIES

\section{COMPUTER PROGRAMS \\ IN \\ OCEANOGRAPHY}

Compiled by C. DINGER

PUBLICATION C-5

(Second Revision)

1970 


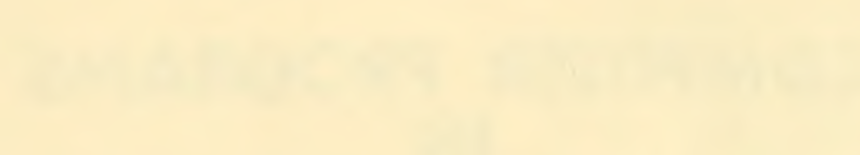
+ 


\section{ACKNOWLEDGMENT}

The cooperation of the individuals and organizations who contributed program abstracts is greatly appreciated. 

This catalog is mainly a compilation of information voluntarily contributed by various individuals and institutions. The National Oceanographic Data Center cannot assume responsibility for the accuracy of the abstracts or the proper functioning of the programs, except for those originated at the Center.

Any information to correct or update the programs in this catalog will be appreciated. 


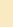


CONTENTS

Introduction. . . . . . . . . . . . . . . 1

Sources of Information. . . . . . . . . . 3

Program Abstracts, by Category. . . . . . . . 5

Biological Oceanography . . . . . . . . 5

Chemical Oceanography . . . . . . . . . 9

Data Reduction. . . . . . . . . . . . 14

Editing and Special Input/Output. . . . . . 21

Geoscience. .. . . . . . . . . . . . 25

Geophysics, Marine. . . . . . . . . 25

Sediment Analysis and Mechanics . . . . 28

Graphical Display . . . . . . . . . . . 33

Mathematics, Applied. . . . . . . . . 45

Curve and Surface Fitting . . . . . . . 45

Mathematical and Statistical Analysis.. . 48

Navigation and Charting ......... . 58

Physical Oceanography . . . . . . . . 666 66

Air-Sea Interaction and Heat Budget . . . 66

Currents and Transfer Processes... . . 68

Ice in the Sea. . . . . . . . . . . 74

Physical Properties: Analyses and

Summaries ........... . . 75

Physical Quantities, Computation of . . . 82

Sound-Ray Path. . . . . . . . . . . 94

Sound-Normal Modes. . . . . . . . . 100

Sound-Speed Computations. . . . . . . . 100

Tides, Astronomical ......... . . . . . . . . . . 103

Waves and Hydromechanics. . . . . . . . 105

Retrieval of Ocean Data......... . . . . . . . . 12

Index by Agency or Institution. . . . . . . . . 115

Index by Programming Language . . . . . . . . . 127

Index by Computer Make and Mode1. . . . . . . . . .135

Computer Program Abstract Form. . . . . . . . . 143 



\section{INTRODUCTION}

This second major revision of the National Oceanographic Data Center's (NODC's) catalog Computer Programs in Oceanography is issued to foster awareness of computer programs related to oceanography and to facilitate their exchange between interested groups.

As in the first revision, the material is arranged under subject headings, with each entry containing the program title, program language, computer system the program is written for, indication whether a copy is on file at NODC, brief program description provided by originator, and name and address of person to contact for further details.

This catalog only begins to reflect the present programs originated by NODC for the new in-house computer. Supplements or revised editions will be issued, and abstracts of NODC's latest programs will be incorporated, as well as contributions from other institutions not received in time for inclusion in this catalog. Also, a revised edition of the NODC publication G-15, User's Guide to NODC's Data Processing Systems, planned for the near future will contain updated computer programming information.

Documentation on file at NODC or assistance in locating a program can be obtained by writing to:

The Director

National Oceanographic Data Center

Washington, D. C. 20390

Contributors of new programs are requested to fill out the abstract form in the back of this catalog and send it to the above address. 
. 
Catalogs of computer programs pertaining to disciplines related to oceanography have been compiled by various organizations. The following is a listing of such publications known to NODC at this time. The Center would appreciate further information about existing computer programs for inclusion in following editions of this catalog.

\section{RESEARCH COMPUTATION CENTER PROGRAM LIBRARY}

A compilation of computer programs written by Naval Research Laboratory personnel. For further information, contact:

Mrs. Janet P. Mason, Code 7813

Mathematics and Information Services Division

Naval Research Laboratory

Washington, D. C. 20390

\section{NATIONAL COMPUTER PROGRAM INDEX}

Includes GOSSIP (Geologically Oriented Scheme for Sharing Information in Programming) and the Rokdoc Package, a library of routines for statistical analysis, summary, and display of data concerning sedimentary rocks. Inquiries should be directed to:

Assistant Librarian

Department of Geology

University of Reading

Whiteknights Park

Reading RGG-2AB

England

COOPERATIVE OCEANOGRAPHIC PROGRAMMING EFFORT (COPE)

A compilation of computer programs in use at the Woods Hole Oceanographic Institution. For further information, contact: 
Editors of COPE

Woods Hole Oceanographic Institution

Woods Hole, Massachusetts 02543

COMPUTER SOFTWARE MANAGEMENT AND INFORMATION CENTER

\section{(COSMIC)}

A catalog of programs generated by the NASA space effort. Many of the programs are of a general nature. For further information, contact:

COSMIC

Computer Center

University of Georgia

Athens, Georgia 30601

\section{NAVAL ORDNANCE LABORATORY LIBRARY \\ OF COMPUTER PROGRAMS}

A catalog of programs in use at the Naval Ordnance Laboratory. For further information, contact:

Mathematics Department

U. S. Naval Ordnance Laboratory

at White Oak

Silver Spring, Maryland 20910

\section{KANSAS GEOLOGICAL SURVEY - COMPUTER CONTRIBUTIONS}

A series of publications devoted to computer programs and examples of problem-solving applications in the earth sciences. For further information, contact:

Dr. Daniel F. Merriam, Editor

Computer Contributions

Kansas Geological Survey

University of Kansas

Lawrence, Kansas 66045 
( COPY ON FILE AT NODC)

COMPUTES THE APPROXIMATE YIELD OF A FISH STOCK PER RECRUITMENT BY EITHER OF TWO METHODS (ARITHMETIC OR EXPONENTIAL APROXIMATIONS), OR THE PROGRAM SIMPLY COMPUTES THE STOCK BIOMASS WHEN THERE IS NO FISHING. OUTPUT-- AN EQUILIBRIUM YIELD MATRIX WITH UP TO 400 ENTRIES CORRESPONDING TO 20 AGES AT ENTRY AND 20 MULTIPLIERS. AUTHORS-- L•V. PIENAAR AND J.A. THOMSON, TECHNICAL REPORT NO. 92 (UNPUBLISHED MANUSCRIPT, NOV 1968). EARLIER VERSION OF PROGRAM WRITTEN BY L. E. GALES, COLLEGE OF FISHERIES, UNIVERSITY OF WASHINGTON. DIRECT INQUIRIES TO -

FISHERIES RESEARCH BOARD OF CANADA BIOLOGICAL STATION NANAIMO, B. C.

\section{CHLOROPHYLL PIGMENT AND CAROTENOID PIGMENT LANGUAGE - FORTRAN II}

( COPY ON FILE AT NODC)

TWO SIMILAR BUT SEPARATE ROUTINES. CALCULATION METHOD BASED ON THE USE OF 1.0 CM. CELLS. DATA CARDS INPUT, OUTPUT IS PRINTED LISTING AND PUNCH CARDS. AUTHOR-- DR. MALCOLM HAIR.

INSTITUTE OF MARINE SCIENCE ADELPHI UNTVERSITY

OAKDALE, LONG ISLAND, N.Y. 11769

\section{COMBINED CHLOROPHYLL AND PRODUCTIVITY}

LANGUAGE - FORTRAN IV

( COPY ON FILE AT NODC) COMPUTER - CDC 6400

COMPUTES ASSIMILATION OF PRODUCTIVITY IN SEA WATER AND COMPUTES THE QUANTITIES OF CHLOROPHYLL A, B, AND C, AND THE AMOUNT OF CAROTENOIDS IN SEA WATER. WRITTEN BY MARSHA WALLIN, NOV 1963. BASED UPON TWO PROGRAMS PREPARED IN 1962 FOR THE IBM 709 BY M.R. RONA. THE CHLOROPHYLL PROGRAM DETERMINES THE AMOUNT OF PLANKTON PIGMENTS USING THE EQUATIONS OF RICHARDS AND THOMPSON. THE PRODUCTIVITY PROGRAM (CARBON 14) DETERMINES THE PRODUCTION OF MARINE PHYTOPLANKTON BY USING NEILSEN.S METHOD. OUTPUT CONSISTS OF BOTH PRINTED MATTER AND OF LIBRARY CARDS. THE LIBRARY CARDS MAY BE USED AS INPUT TO A MULTIPLE REGRESSION PROGRAM TO DERIVE A RELATION BETWEEN PRODUCTIVITY AND CHLOROPHYLL A. FINALLY, A PLOT ROUTINE MAY BE CALLED TO GRAPH ONE OR SEVERAL VARIABLES AS A FUNCTION OF DEPTH, OR TO DISPLAY THE HORIZONTAL DISTRIBUTION OF ANY GIVEN PROPERTY. REVISED IN 1969 FOR THE CDC-6400.

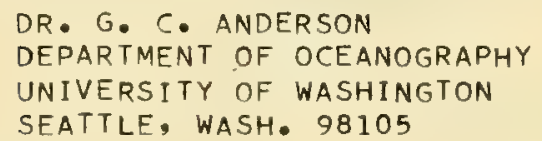

ECOPROD

LANGUAGE - FORTRAN IV

( COPY ON FILE AT NODC) COMPUTER - CDC 6600

COMPUTES GROSS AND NET PRODUCTIVITY, RESPIRATION, P/R RATIO, PHOTOSYNTHETIC QUOTIENT, EFFICIENCY, DIFFUSION COEFFICIENT, GIVEN SUNLIGHT DATA AND DIURNAL MEASURES OF OXYGEN AND/OR CARBON DIOXIDE. CORE STORAGE REQUIRED - 25,000 60-BIT WORDS. AUTHOR-- WILLIAM LONGLEY. 
ICOPY ON FILE AT NODCI

CALCULATES SPECIES DIVERSITY INDEX FOR NUMBERS OF ORGANISMS AND/OR WEIGHT OF ORGANISMS, UTILIZING THE DIVERSITY INDEX EQUATION DERIVED FROM MARGALEF. PROGRAM CALLS SUBROUTINE 'SEASON' WHICH CALCULATES SEASONAL AVERAGES FOR A GIVEN STATION, SEASONAL LIMITS BEING INDICATED BY A CONTROL CARD. THIS SUBROUTINE OUTPUTS MEAN, STANDARD DEVIATION, AND RANGE OF DIVERSITY INDICES FOR EACH SEASONAL GROUP. OTHER DESIRED GROUPINGS MAY BE ENTERED BY A GROUPING CONTROL CARD. CORE STORAGE NECESSARY-- 50,000 60-BIT WORDS. AUTHOR-- A.D. EATON.

WILLIAM LONGLEY

THE UNIVERSITY OF TEXAS

MARINE SCIENCE INSTITUTE

PORT ARANSAS, TEXAS 78373

OXYGEN

LANGUAGE - FORTRAN IV

(COPY ON FILE AT NOOC)

COMPUTER - CDC 6600

DETERMINES PRODUCTIVITY BY OXYGEN DIURNAL CURVE METHOD. INPUT INCLUDES OXYGEN CONCENTRATION AND OXYGEN PROBE PARAMETERS. OUTPUT CONTAINS NET AND GROSS PRODUCTIVITY AND P/R PLUS ORIGINAL DATA. AUTHOR-- WILLIAM LONGLEY.

THE UNIVERSITY OF TEXAS

MARINE SCIENCE INSTITUTE

PORT ARANSAS, TEXAS 78373

MARINE BIOLOGICAL ENVIRONMENTAL SUMMARIES

LANGUAGE - FORTRAN

COMPUTER - IBM 7074

CODED CHARACTERISTICS FOR SPECIFIED LOCALITIES ARE SUMMARIZEO FOR THE FOLLOWING MARINE BIOLOGICAL PHENOMENA-- AMEIENT BACKGROUND NOISE, ATTACHED AND FLOATING MARINE VEGETATION, BIOLUMINESCENCE, AND DANGEROUS MARINE LIFE. CHARACTERISTICS INCLUDE-- HABITAT, PERIOD OF ACTIVITY, FREQUENCY, RANGE OF SOUND, MAXIMUM SOUND PRESSURE LEVEL, AREAL DISTRIBUTION OF MARINE VEGETATION, TYPE AND INTENSITY OF BIOLUMINESCENCE, AND CAUSES AND EFFECTS OF SPECIFIED DANGEROUS MARINE LIFE. AUTHOR-R.M. HOLCOMBE. OS NO. 53338 .

OCEANOGRAPHIC ANALYSIS DIV., CODE 3301

NAVAL OCEANOGRAPHIC OFFICE

SUITLAND, MO. 20390

LENGTH-WEIGHT FREOUENCY

LANGUAGE - FORTRAN IV

COMPUTER - IBM $360 / 65$

CALCULATES LENGTH-WEIGHT FREQUENCY DISTRIBUTION VALJES FROM SKIPJACK CATCH DATA.

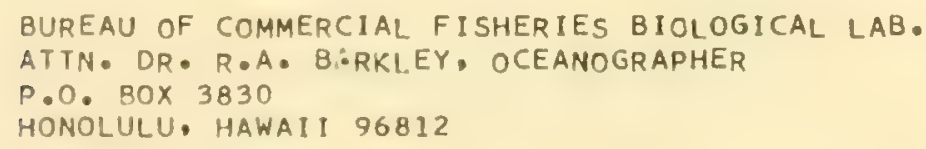

BIODETERIORATION PROJECT

LANGUAGE - AUTOCODER

(COPY ON FILE AT MODC)

COMPUTER - IBM 7074

MONTHLY AND YEARLY SUMMARIES OF THE RESULTS OF FOULING MEASURED ON EXPOSEO AND CONTROL PANELS. OS INO. 52272. AUTHOR-- JUDY YAVNER. 
CONCENTRATIONS PER SQUARE METER OF SURFACE IN THE OCEAN AND LAKES FROM CONCENTRATIONS PER VOLUME (UWMS-1006)

( COPY ON FILE AT NODC)

COMPUTES VARIOUS CHEMICAL AND BIOLOGICAL COMPOUND CONCENTRATIONS AS WELL AS PRODUCTIVITY RATES PER SQUARE METER OF WATER SURFACE, FRCM INTEGRATED VALUES ON IPER VOLUME' BASIS. TEN CONCENTRATIONS AND RATES ARE INTEGRATED OVER UP TO SEVEN PAIRS OF OPTIONAL DEPTH LIMITS. REF. A 31-PAGE REPORT (UWMS-1006, JUN 1966) BY THE DEPARTMENT OF OCEANOGRAPHY, APPLIED MATHEMATICS SECTION. CORE STORAGE NEEDED- 2231 HORDS. SOURCE DECK HAS 771 CARDS.

\author{
H. MACINTOSH, COMPUTER SERVICES \\ DEPARTMENT OF OCEANOGRAPHY \\ UNIVERSITY OF WASHINGTON \\ SEATTLE, WASH. 98105
}

PHYTOPLANKTON NUMBERS, VOLUMES AND SURFACE AREAS BY SPECIES (UWMS-1008 AND UWMS-1009)

\author{
LANGUAGE - FORTRAN IV \\ COMPUTER - IBM 7094-II/ \\ 7040 DCS
}

(COPY ON FILE AT NODC)

TWO PROGRAMS. DIFFERING IN INPUT FORMAT ONLY, COMPUTE CONCENTRATIONS OF CELL NUMBERS, CELL SURFACE AREAS, AND CELL AND PLASMA VOLUMES IN MARINE PHYTOPLANKTON POPULATIONS. ALSO MEAN CELL AREAS, MEAN CELL VOLUMES AND MEAN PLASMA VOLUMES AS WELL AS THE RATIOS CELL AREA TO CELL VOLUME AND CELL AREA TO PLASMA VOLUME ARE COMPUTED OPTIONALLY. THE INPUT QUANTITIES ARE OBTAINED FROM MICROSCOPICAL EXAMINATION OF SEAWATER SAMPLES. A SUBROUTINE COMPUTES THE AREA, VOLUME AND PLASMA VOLUME OF A CELL FROM MEASURED DIMENSIONS OF DIVERSE SPECIES. CORE STORAGE REQUIRED-- 23,836 WORDS FOR MAIN PROGRAM AND SUBROUTINES IN FORTRAN AND MAP. SOURCE DECK HAS 1211 CARDS. REF. A 93 PAGE REPORT-SPECIAL REPORT NO. 38 (M66-41, JULY 1956), BY PAAVO E. KOVALA AND JERRY D. LARRANCE.

H. MACINTOSH, COMPUTER SERVICES

DEPARTMENT OF OCEANOGRAPHY

UNIVERSITY OF WASHINGTON

SEATTLE, WASH. 98105

CALCULATES CHLOROPHYLL USING THE FORMULA OF STRICKLAND IN 'A MANUAL OF SEA WATER ANALYSIS' PP. 110-112. AUTHORS- A.M. SHIPLEY AND D. SACKS.

\author{
UNIVERSITY OF CAPE TOWN \\ OCEANOGRAPHY DEPARTMENT \\ -TTN. MR. A.M. SHIPLEY \\ PRIVATE BAG, RONDEBOSCH, C.P. \\ REPUBLIC OF SOUTH AFRICA
}

\section{PROGRAM REGROUP}

I COPY ON FILE AT NODCI

THE PROGRAM DETERMINES THE NUMBERS OF OCCUROENCES AND JOINT OCCURRENCES OF THE SPECIES IN THE SET OF SAMPLES. IT THEN CALCULATES AN INDEX OF AFFINITY FOR EACH PAIR OF SPECIES. THE SPECIES ARE ORDERED IN TERMS OF THE NUMBERS OF AFFINITIES THEY HAVE AND THIS LIST IS PRINTED ALONG WITH A LIST OF NAMES, CODE NUMBERS AND NUMBERS OF OCCURRENCES. THE PROGRAM THEN DETERMINES THE LARGEST GROUP THAT COULD BE FORMED, TESTS TO SEE WHETHER THAT MANY SPECIES ALL HAVE AFFIMITY WITH EACH OTHER AND, IF THEY DO, PRINTS OUT THE GROUP. IF THEY DO NOT IT 
TRIES THE NEXT SMALLER GROUP. ETC. THOSE SPECIES WHICH HAD AFFINITY ONLY WITH THIS GROUP - ANDIOR EARLIER GROUPS - ARE LISTED. THE RE-

MAINING SPECIES ARE REORDERED AND THE PROCESS CONTINUED UNTIL ALL SPECIES HAVE BEEN PUT EITHER IN GROUPS OR IN THE LIST OF SPECIES WITH AFFINITIES WITH GROUPS. LIMITS-- 200 SPECIES. DIRECT INQUIRIES TO--

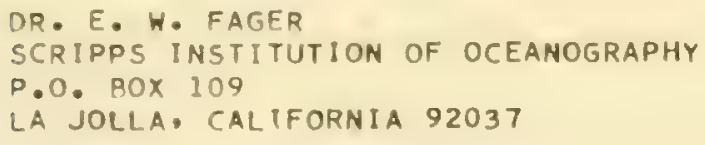

CHLOR

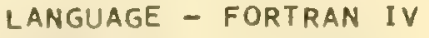

THIS PROGRAM WILL EITHER CALCULATE CHLOROPHYLL A, B, C CONCENTRATIONS IA MICROGRAMS PER LITER OF SEAHATER AND THE CONVERSION FACTORS FOR THE FLUOROMETER USING SPECTROPHOTOMETER READINGS, OR CALCULATE CHLOROPHYLL A AND PHAEOPHYTIN CONCENTRATIONS IN MICROGRAMS PER LITER OF SEAWATER, USING THE FLUOROMETER READINGS. A SIMILAR PROGRAM WAS WRITTEN EARLIER AT S.I.O. FOR THE CDC 1604.

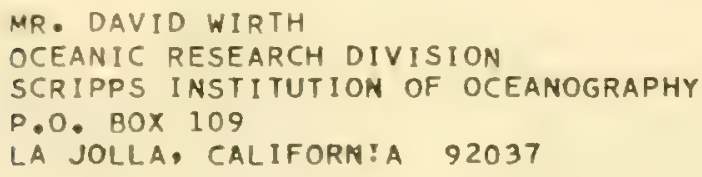

NUTRIENT CHEMISTRY CONCENTRATION

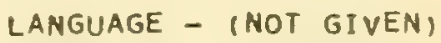

COMPUTES CONCENTRATIONS OF INORGANIC PHOSPHORUS, SILICATE, NITRITE, NITRATE, FROM THE APPROXIMATE RAW DATA.

SCRIPPS INSTITUTION OF OCEANOGRAPHY

LA JOLLA, CALIFORNIA 92037

PRIMARY PRODUCTIVITY

LANGUAGE - (NOT GIVEN)

COMPUTER - CDC 1604

COMPUTES PRIMARY PRODUCTIVITY FROM ACTIVITY OF CARBON, DURATION OF INCUBATION, TYPE OF INCUBATION, SAMPLE ACTIVITY AND DEPTH.

SCRIPPS INSTITUTION OF OCEANOGRAPHY

LA JOLLA, CALIFORNIA 92037

ZOOPLANKTON VOLUME

LANGUAGE - (NOT GIVEN)

COMPUTER - CDC 1604

COMPUTES ZOOPLANKTON VOLUME FROM VARIOUS TYOES OF HAUL.

SCRIPPS INSTITUTION OF OCEANOGRAPHY

LA JOLLA, CALIFORNIA 92037 
THE INPUT CARDS OF THIS PRGGRAM ARE PRE-PUNCHED WITH THE STATION NUMBER, DATE, WIRE LENGTH AND BOTTLE NUMBER, THEN SENT TO THE CHEMISTRY LABORATORY WHERE THE PH VALUE AND THE SALINITY VALUE ARE PUNCHED ON THE CARDS. THE CARDS ARE THEN RETURNED AND PROCESSED THROUGH THE COMPUTER.

\author{
UNIVERSITY OF MIAMI \\ MARINE LABORATORY \\ COMPUTING CENTER \\ 1 RICKENBACKER CAUSEWAY \\ VIRGINIA KEY. MIAMI. FLORIDA
}

SALINITY VALUE CALCULATION

\author{
LANGUAGE - FORTRAN AND \\ FORCOM \\ COMPUTER - IBM 1620
}

THE INPUT CARDS ARE PRE-PUNCHED WITH STATION NUMBER, DATE, WIRE LEMGTH AND BOTTLE NUMBER, THEN SENT TO THE CHEMISTRY LABORATORY WHERE THE $X$ AND Y ARM READINGS ARE PUNCHED. THE CARDS ARE THEN RETURNED AND PROCESSED THROUGH THE COMPUTER. AN 80-80 BOARD ON THE IBM 407 IS USED FOR LISTING THE OUTPUT OF THIS PROGRAM.

\author{
UNIVERSITY OF MIAMI \\ MARINE LABORATORY \\ COMPUTING CENTER \\ 1 RICKENBACKER CAUSEWAY \\ VIRGINIA REY, MIAMI, FLORIDA
}

SPECIAL CHEMISTRY CALCULATIONS

LANGUAGE - FORTRAN IV

COMPUTER - IBM 1130

READS SPECIAL CHEMISTRY (PHOSPHATE, SILICATE, NITRATE, ETC.) RAW DATA CARDS, AND COMPUTES FINAL VALUES, OUTPUT FROM THE PROGRAM-- WORKING RECORD OF THE DATA FILE, FINAL REPORT IN PUBLISHABLE FORM, PLOTS OF ANY VARIABLES VS. DEPTH, PLOTS OF ANY VARIABLE VS. VARIABLE, AND STANDARD OBSERVED CARDS. DOCUMENTATION-- OPERATING INSTRUCTIONS ONLY.

UNIVERSITY OF WASHINGTON

DEPARTMENT OF OCEANOGRAPHY

22A OCEANOGRAPHY TEACHING BLDG.

ATTN. MRS. HELLA MACINTOSH

SEATTLE, WASH. 98105

\title{
WATER CHEMISTRY
}

LANGUAGE - FORTRAN IV
COMPUTER - IBM $360 / 65$

(COPY ON FILE AT. NODC)

CALCULATES THE DIELECTRIC CONSTANT OF WATER 0 TO 360 DEG. C IHATER SATURATED FOR T OVER 100 DEG. C), THE DENSITY OF WATER 10 TO 360 DEG. C). THE EXTENDED DEBYE-HUECKEL ACTIVITY COEFFICIENTS OF CHARGED SPECIES, THE ACTIVITY PRODUCTS FOR 33 HYDROLYSIS REACTIONS INCLUDING OXIDES, HYDROXIDES, CARBONATES, SULFIDES AND SILICATES, THE CONCENTRATIONS AND ACTIVITIES OF 10 ION PAIRS OR COMPLEXES, AND OF 22 AQUEOUS SPECIES, THE OXIDATION POTENTIAL CALIBRATIONS, THE STANDARD STATE OXIDATION POTENTIALS AND EH VALUES AT EQUILIBRIUM FOR 13 REDOX REACTIONS, MOLES AND PPM OF CATIONS AT EQUILIBRIUM WITH 42 SOLIO PHASES AND THE CHEMICAL POTENTIALS FOR EACH OF THE 42 REACTIONS ALONG WITH ACTIVITY PRODUCT/EQUILIBRIUM CONSTANT RATIOS FOR THE HYDROLYSIS REACTIONS. PROGRAM NO. MO101, FEB 1968. 
GIVES OXYGEN IN ML/L, MG/L, AND PERCENT SATURATION. ALSO GIVES APPARENT OXYGEN UTILIZATION, NITROGEN IN ML/L, AND NITROGEN PERCENT SATURATION. THE PROGRAM WILL ACCEPT DATA DERIVED FROM EITHER GAS PARTITIONER OR TITRATION METHODS. OS PROGRAM NO. 59209, 8Y GORDON WILCHER.

OCEAN SURVEYS DIVISION, CODE 9230

NAVAL OCEANOGRAPHIC OFFICE

SUITLAND, MD. 20390

SAL INITY

( COPY ON FILE AT NODC)

CONVERTS READINGS FROM THE SALINOMETER TO SALINITIES, GIVEN THE TEMPERATURE AND CONDUCTIVITY RATIO • TELETYPE I 10 .

COMMANDING OFFICER

U.S. COAST GUARD OCEANOGRAPHIC UNIT

BLDG. I59-E, NAVY YARD ANNEX

WASHINGTON, D. C. 20390

\section{OXYGEN}

(COPY ON FILE AT NODC)

COMPUTES VALUES OF OXYGEN. TELETYPE I/O.

COMMANDING OFFICER

U.S. COAST GUARD OCEANOGRAPHIC UNIT

BLDG. 159-E, NAVY YARD ANNEX

WASHINGTON, D. C. 20390

PHOSPHATE

(COPY ON FILE AT NODC)

COMPUTES PHOSPHATE VALUES. TELETYPE I $/ 0$.

COMMANDING OFFICER

U.S. COAST GUARD OCEANOGRAPHIC UNIT

BLDG. 159-E, NAVY YARD ANNEX

HASHINGTON, D. C. 20390
LANGUAGE - FORTRAN IV

COMPUTER - HONEYWEILL516
LANGUAGE - FORTRAN IV

COMPUTER - HONEYWEILL516

INDUCTIVE SALINOMETER SALINITY CONVERSION

LANGUAGE - PDP 8 FORTRAN

COMPUTER - PDP-5, 85

(COPY ON FILE AT NODC)

ACCEPTS BOTTLE NUMBER, TEMPERATURE OF SAMPLE, AND CONDUCTIVITY RATIO

OF SAMPLE AND OUTPUTS A SALINITY CORRECTED FOR TEMPERATURE AND SHEAR.

COMMANDING OFFICER

U.S. COAST GUARD OCEANOGRAPHIC UNIT

BLDG. 159-E, NAVY YARD ANNEX

WASHINGTON, D. C. 20390

SPECIFIC CONDUCTIVITY WITH PRESSURE EFFECT

LANGUAGE - FORTRAN

COMPUTER - IBM OS/360

( COPY ON FILE AT NODC)

COMPUTES SPECIFIC CONDUCTIVITIES FROM MEASURED VALUES OF RESISTANCE FOR THE ELECTROLYTIC SOLUTION AND THE PRESSURES AT WHICH THE MEASUREMENTS WERE MADE. THE PROGRAM ALSO DETERMINES OTHER USEFUL QUANTITIES NEEDED TO DETERMINE THE EFFECT OF PRESSURE ON THE IONIC CONDUCTANCE THROUGH THE UPPER 2000 METERS OF THE OCEAN'S WATER COLUMN. THE CONDUCTIVITY INCREASE WHICH RESULTS SOLELY FROM SOLUTION CONCENTRATION CHANGES DURING COMPRESSION IS DETERMINED AND FOUND TO BE A SIGNIFICANT 
ERROR SOURCE. REF. THESIS BY MICHAEL E. MAYS (DEC 1968, 89 P).

NAVAL POSTGRADUATE SCHOOL

MONTEREY, CALIFORNIA 93940

SALINITY - CONDUCTIVITY FORMULA

LANGUAGE - FORTRAN

COMPUTER - IBM 7074

EVALUATES A NEWLY DEVELOPED EQUATION RELATING SEA WATER ELECTRICAI. CONDUCTIVITY AND SALINITY. AUTHOR-- W.L. GUIDRY. OS NO. 20184.

COMPUTER DEPARTMENT, CODE 0831

NAVAL OCEANOGRAPHIC OFFICE

SUITLAND, MD. 20390

CHLORINITY - SALINITY

LANGUAGE - FORTRAN II

COMPUTFR - IBM 7094

SUBROUTINE COMPUTES CHLORINITY AND SALINITY FROM MEASUREMENTS OF TEMPERATURE AND CONDUCTIVITY. USES MODIFICATION OF POLLAKIS (1954) EQUA-

TIONS RELATING CONDUCTIVITY, TEMPERATURE, AND CHLORINITY.

MARVEY E. WALTERS

CHESAPEAKE BAY INSTITUTE

THE JOHNS HOPKINS UNIVERSITY

CHARLES AND 34 TH ST.

BALTIMORE, MD. 21218

TOTAL CO(2)

LANGUAGE - FORTRAN II

COMPUTER - IBM 7094

COMPUTES TOTAL CO(2) FROM MEASUREMENTS OF TEMPERATURE, CHLORINITY, PH, AND ALKALINITY. FOLLOWS METHOD OF H.W. HARVEY (1960). LINEAR INTERPOLATION IN TWO VARIABLES IS PERFORMED IN THE TABLES. OUTPUT IS A TABULATION FOR EACH STATION OF DEPTH, INPUT DATA, AND TOTAL CO(2). OPTIONALLY, OFF-LINE CALCOMP PLOTS OF TOTAL CO(2) VS. DEPTH CAN BE PRODUCED. CORE STORAGE NECESSARY- 3430 WORDS PLUS PLOTTER ROUTINES.

HARVEY F. WALTERS

CHESAPEAKE BAY INSTITUTE

THE JOHNS HOPKINS UNIVERSITY

CHARLES AND 34 TH ST.

BALT IMORE, MD. 21218

GAMMA-RAY SPECTRA

LANGUAGE - FORTRAN

COMPUTER - (NOT GIVEN)

(COPY ON FILF. AT NODC)

IDENTIFIES AND MEASURES COMPONENTS IN A MIXTURE OF GAMMA-EMITTING RADIONUCLIDES. THE COMPUTER PROGRAM WILL BE USEFUL IN ANALYZING THE LARGE NUMBER OF LOW ACTIVITY MIXTURES OF RADIONUCLIDES THAT ARE TO BE MADE IN THE PROGRAM TO DETERMINE THE PHYSICAL-CHEMICAL SPECIES OF THE RADIONUCLIDE DEBRIS PRODUCEO BY UNDERWATER NUCLEAR EXPLOSIONS. REF. REPORT TR-67-46, U.S. NAVAL RADIOLOGICAL DEFENSE LABORATORY, BY JAMES F. PESTANER AND DANIEL L. LOVE.

DIVISION OF BIOLOGY AND MEDICINE

U.S. ATOMIC ENERGY COMMISSION

WASHINGTON, D. C. 20545

OPTIMIZATION OF VTE SALINE WATER PLANTS

LANGUAGE - FORTRAN IV

COMPUTER - IBM 7094

ICOPY ON FILF. AT NODC,

PROGRAM AND SURROUTINES TO DEVELOP AN OPTIMUM DESIGN OF A MIMIMUM COST VTF (VERTICAL TUBE EVAPORATOR) FALLING FILM PLANT FOR PRODUCING FRESH WATER FROM SEA WATER. RESEARCH AND DEVELOPMENT PROGRESS REPORT NO. 
404 (FEB $1969,164 \mathrm{P}$ ).

U.S. DEPARTMENT OF THE INTERIOR OFFICE OF SALINE WATER

WASHINGTON, D.C. 20240 
PHYSICAL OCEANOGRAPHY DATA REDUCTION

LANGUAGE - FORTRAN II

DROGRAMS FOR THE CDC 3100

COMPUTER - CDC 3100

( COPY ON FILE AT NODC)

AN OCEANOGRAPHIC DATA PROCESSING SYSTEM DESIGNED TO ACCEPT THE DATA FROM THE ORIGINAL LOG SHEETS. COMPUTES OBSERVED TEMPERATURES AND PRESSURES FROM THERMOMETER READINGS, SALINITIES FROM THE CONDUCTIVITY RATIO READINGS, THE DISSOLVED OXYGEN FROM THE TITRES AND THE REACTIVE SILICA CONCENTRATIONS FROM THE OPTICAL DENSITIES. THE DATA INPUT MAY BE PUNCHED PAPER TAPE FROM THE PDP-8 SYSTEM (B. I COMPUTER NOTE 68-5C) OR PUNCHED CARDS. THE FINAL PROGRAM IN THE SYSTEM COMPUTES DEPTH, POTENTIAL TEMPERATURE, SURFACE DENSITY ANOMALY, POTENTIAL SURFACE DENSITY ANOMALY AND SPECIFIC VOLUME ANOMALY. THE PROGRAM ALSO CAN COMPUTE THE DYNAMIC HEIGHT AND POTENTIAL ENERGY ANOMALY AT GIVEN PRESSURES AND MAY ALSO GIVE A MAGNETIC TAPE OF THE DATA IN CARD IMAGE OF THE CODC FORMAT. CORE STORAGE-- 16K. REF. B. I. COMPUTER NOTE 68-10-C (OCT 1968,280 PAGES), BY R. REINIGER, C.K. ROSS, P. TRITES AND D.J. LAWRENCE.

DIRECTOR

ATLANTIC OCEANOGRAPHIC LABORATORY

BEDFORD INSTITUTE

DARTMOUTH, NOVA SCOTIA, CANADA

\author{
PHYSICAL OCEANOGRAPHY DATA REDUCTION \\ LANGUAGE - PAL III \\ TROGRAMS FOR THE PDP-8
}

(COPY ON FILE AT NODC)

A SYSTEM OF PROGRAMS THAT ACCEPTS RAW DATA AS RECORDED ON DECK SHEETS. CALCULATES THE CORRECTED TEMPERATURES, USES THE HIGHEST ORDER LEAST SQUARES FIT TO OBTAIN THE SMOOTHED PRESSURES, CALCULATES DEPTH, SPECIFIC VOLUME ANOMALY, POTENTIAL TEMPERATURE, AND DENSITY ANOMALIES. ALSO FORMATS RAW CHEMISTRY DATA. INCLUDES A SET OF PLOTTING ROUTINES. CORE STORAGE-- 4K. REF. B.I. COMPUTER NOTE 68-5-C (258 P, MAY 1968), BY C.K. ROSS, R. REINIGER, A.B. GRANT.

DIRECTOR

ATLANTIC OCEANOGRAPHIC LABORATORY BEDFORD INSTITUTE

DARTMOUTH, NOVA SCOTIA, CANADA

STAOAT 2

LANGUAGE - FORTRAN II COMPUTER - GE 225

( COPY ON FILE AT NODC)

A CHAIN OF EIGHT PROGRAMS WHICH REDUCE AND EDIT HYDROGRAPHIC STATION DATA, CALCULATE AND SMOOTH THERMOMETRIC DEPTHS. BASED UPON WOODS HOLE 0.1. PROGRAM IHYLOG' (VERSION FOR GE-225). THE FINAL DATA MAY BE EITHER A PRINTOUT OR NODC FORMAT PUNCHCARDS. REF, BIO COMPUTER NOTE 665-C. AUTHOR-- F.K. KEYTE. ISEE ALSO ION THE FORMULAS FOR CORRECTING REVERSING THERMOMETERS I REF. NO. 64-29, WHOI, BY FREEMAN K. KEYTE.)

BEDFORD INSTITUTE

DARTMOUTH, N.S., CANADA

REDUCTION AND DISPLAY OF DATA ACQUIRED AT SEA

LANGUAGE - FORTRAN II

COMPUTER - IBM 1130

( COPY ON FILE AT NODC)

A SYSTEM OF PROGRAMS (NAVIGATION, GRAVITY, TOPOGRAPHY, MAGNETICS) FOR THE REDUCTION, STORAGE AND DISPLAY OF UNDERWAY DATA ACQUIRED AT SEA. THE COMPUTER INSTALLATION CONSISTS OF AN IBM 1130 AND INCLUDES RANDOM ACCESS DISK CARTRIDGES AND AN ON-LINE CALCOMP 30 IN. PLOTTER. A. IARGE 
NUMBER OF THE PROGRAMS UTILIZE NAVIGATION POINTS TOGETHER WITH RAW DIGITIZED GEOPHYSICAL DATA PRESEISTED AS A TIME SERIES, WHERE THE DIFFERENT DATA MAY BE READ AT UNEQUAL TIME INTERVALS. REF• TECH. REPORT NO. 1 (AUGUST 1969,348 P.) BY MANIK TALWANI.

\author{
LAMONT-DOHERTY GEOLOGICAL OBSERVATORY \\ COLUMBIA UNIVERSITY \\ PALISADES, NEW YORK 10964
}

RICHARDSON CURRENT METER FILM READING

$$
\begin{aligned}
& \text { LANGUAGE - DECAL } \\
& \text { COAPUTER - PDP } 7(9)
\end{aligned}
$$

A SYSTEM OF PROGFAMS UNDER AN ON-LINE TYPEWRITER CONTROL PROGRAM TO AUTOMATICALLY READ DATA (CURRENT SPEED AND DIRECTION), RECORDED ON 16MM FILM, INTO A PDP-7 COMPUTER, USING A PROGRAMMABLE FILM READING DEVICE. DATA OUTPUT IS AVAILABLE IN THE FORM OF NUMERICAL LISTINGS OR IN DIGITAL FORM ON MAGNETIC TAPE. A DIGITAL X-Y PLOTTER MAY ALSO BE USED TO PRODUCE GRAPHS AND HISTOGRAMS OF CURRENT SPEED AND DIRECTION. THE MOST IMPORTANT IN THE SYSTEM OF PROGRAMS IS THE ININEPOINT FILM READER'. THE OTHER PROGRAMS ARE-- 'CHANNEL POSITIONING', 'ENTER CHANNELS', IWRITE DATA', 'GRAPHING!, 'CLEAR NINEPOINT RECORD', 'AUTOMATIC FRAME ADVANCEI, 'LEFT OR RIGHT SCAN', 'ALL CHANNELS ON TOTALS', 'DOT SCANNINGI, 'DIAMOND SCANNERI, 'MICROSCOPE', AND 'TEST SINGLE CHANNEL'. BROCHURE DESCRIBING THE SYSTEM IS AVAILABLE ON REQUEST.

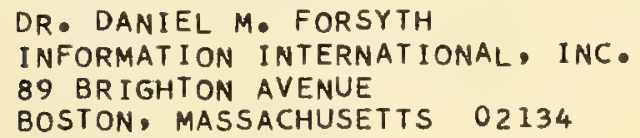

BRAINCON DATA REDUCTION

LANGUAGE - FORTRAN IV

COMPUTER - IBM 1800 SYS

( COPY ON FILE AT NODC)

CONVERTS DATA IN THE FORM OF ANGULAR POSITIONS OF THE ROTOR AND COMPASS ARCS FROM BRAINCOM TYPE 316 CURRENT METERS INTO VALUES OF CURRENT SPEED AND DIRECTION, TILT DIRECTION, N-S AND E-W CURRENT COMPONENTS AND DISPLACEMENTS (IN KILOMETRES) FROM ANY ARBITRARY ORIGEN. DATA IS OUTPUT TO LINEPRINTER WITH COLUMN HEADINGS AND MAGNETIC TAPE WITHOUT HEADINGS. EXECUTION TIME-- OF THE ORDER OF 3 MINS. PER 100 CARDS 12 MINS. FOR ONE DAY OF RECORDI. N.I.O. PROGRAM NO. 17B. AUTHOR-- W. J. GOULD.

MATIONAL INSTITUTE OF OCEANOGRAPHY

WORMLEY, GODALMING, SURREY

ENGLAND

Q FACTORS

LANGUAGE - FORTRAN $V$ COMPUTER - ATLAS I

CALCULATES THE PRESSURE IN DECIBARS FROM THE READING OF T(U)-T(W) GIVEN BY AN UNPROTECTED REVERSING THERMOMETER. THE OUTPUT CONSISTS OF A TABLE OF VALUES OF PRESSURE FOR TEMPERATURES IN STEPS OF 0.1 DEGR C. N.I.O. PROGRAM 63. AUTHOR-- ELIZABETH PALETHORPE. DESCRIBED IN N.I.O. INTERNAL REPORT NO. 7, JAN 1968.

NATIONAL INSTITUTE OF OCEANOGRAPHY WORMLEY, GODALMING, SURREY ENGLAND

NIO PROGRAM 59 - THERMOMETER CORRECTIONȘ FOR DEEP-SEA REVERSING THERMOMETERS
LANGUAGE - CHLF $3 / 4$

COMPUTER - MERCURY

BOTH PROTECTED AND UNPROTECTED THERMOMETERS CAN BE DEALT WITH. CORRECTIONS ARE DEPENDENT ON THE WATER TEMPERATURE, THE AMBIENT TEMPERATURE IN THE LABORATORY, AND THE INDEX ERRORS OF THE THERHOMETERS. AUTHOR-- JAMES CREASE. REF. N.I.O. INTERNAL REPORT NO. NG. 
NATIONAL INSTITUTE OF OCEANOGRAPHY

WORMLEY, GODALMING. SURREY

ENGLAND

DEEP

LANGUAGE - FORTRAN

COMPUTER - HP $2115 \mathrm{~A}$

ICOPY ON FILE AT NODC)

DIGITIZES SALINITY-TEMPERATURE-DEPTH DATA ON LINE USING TIME AS CRI-

TERION FOR SELECTING POINTS. INPUT ARE FREQUENCIES FROM S.T.D. SYSTEM

AND STATION HEADING DATA THROUGH TELETYPE. OUTPUT ON PAPER TAPE HAS

STATION IDENTI:ICATION FIELDS, TIME INTERVAL BETWEEN DATA POINTS, AND

THE S.T.D. DATA - PRESSURE, TEMPERATURE, SALINITY. REF. FRB TECHNICAL

REPORT NO. 152 (DEC 1969 ), BY A. HUYER AND C. A. COLLINS (UNPUB. MS.)

OR. C. A. COLLINS

MARINE SCIENCES BRANCH, DEMR

PACIFIC OCEANOGRAPHIC GROUP

BIOLOGICAL STATION

NANAIMO, B.C., CANADA

\title{
TEHK2 (THERMOMETER CORRECT)
}

LANGUAGE - FORTRAN VI

COMPUTER - IBM 1130

( COPY ON FILE AT NODC)

PURPOSE-- TO CORRECT DEEP-SEA REVERSING THERMOMETERS, TO COMPUTE THERMOMETRIC DEPTHS, TO ALLOW SPURIOUS VALUES TO BE REMOVED FROM THE L-Z

TABLE, TO SMOOTH THE L-Z TABLE, AND TO PUNCH SMOOTHED DEPTH AND OB-

SERVED TEMPERATURE AND SALINITY AND OXYGEN VALUES ONTO CARDS IN CODC FORMAT. PROGRAM AND SUB-PROGRAMS DESCRIBED IN FRB MANUSCRIPT REPORT NO. 1071 (DEC 1969, UNPUBLISHED MANUSCRIPT), BY C. A. COLLINS, R. L. K. TRIPE, AND S. K. WONG. POG HAS TWO OTHER THERMOMETER CORRECTION PROGRAMS - TCHKI USES THE L/Z METHOD, TCHK 3 COMPUTES PRESSURE.

PACIFIC OCEANOGRAPHIC GROUP

BIOLOGICAL STATION

NANAIMO, B.C., CANADA

TEMPERATURE AND DEPTH CALCULATIONS

$\begin{aligned} \text { LANGUAGE - } & \text { FORTRAN AND } \\ & \text { AUTOCODER }\end{aligned}$

COMPUTER - IBM 1620 AND

IBM 1401

(COPY ON FILE AT NODC)

AT PRESENT THERE IS NO PROVISION FOR CALCULATING WIRE ANGLE DEPTH.

DENSITY VALUES USED ARE THOSE FOR THE NORTH ATLANTIC. THE INPUT IS IN

TWO PARTS. FIRST THE THERMOMETER TABLES ARE READ IN, THEN THE DATA

CARDS. THE OUTPUT CARD IS A REPRODUCTION OF THE INPUT DATA CARD, PLUS

ALL NECESSARY CALCULATIONS. AUTHORS-- D.T. EGER, D.L. SHAFFER.

\author{
UNIVERSITY OF MIAMI \\ MARINE LABORATORY \\ COMPUTING CENTER \\ I RICKENBACKER CAUSEWAY \\ VIRGINIA KEY, MIAMI, FLORIDA
}

THERMOMETER CORRECTION

LANGUAGE - FORTRAN IV

COMPUTER - HONEYWEILLI6

(COPY ON FILE AT NODC)

CORRECTS DEEP-SEA REVERSING THERMOMETERS AND CALCULATES THERMOMETRIC DEPTHS, GIVEN THE THERMOMETER CONSTANTS AND THE INDIVIDUAL THERMOMETER READINGS. TELETYPE I/O - HIGH SPEED PAPER TAPE READER DESIRAULE.

COMMANDING OFFICER

U.S. COAST GUARD OCEANOGRAPHIC UNIT

BLDG. 159-E. NAVY YARD ANNEX

WASHINGTON, D. C. 20390 
(COPY ON FILE AT NODC)

CORRECTS DEEP-SEA REVERSING THERMOMETERS, CALCULATES THERMOMETRIC DEPTH. AUTHOR-- LEO M. FLETCHER. THE ORIGINAL VERSION, WITH DOCUMENTATION, WAS WRITTEN IN FORTRAN FOR THE IBM 1620.

CANADIAN OCEANOGRAPHIC DATA CENTRE 615 BOOTH STREET

OTTAWA, CANADA

TWO FIVE (HYDROGRAPHIC DATA REDUCTION)

$$
\begin{aligned}
\text { LANGUAGE - } & \text { FORTRAN } 63, \\
\text { COMPUTER - } & \text { FORTRAN IV } \\
& \text { IBM } 1800
\end{aligned}
$$

PROCESSES RAW DATA TO OBTAIN CORRECTED DEPTH, TEMPERATURE, SALINITY, AND OXYGEN-- 1$)$ PROTECTED DEEP-SEA REVERSING THERMOMETER READINGS TO OBTAIN THE CORRECTED IN-SITU WATER TEMPERATURE. 2) UNPROTECTED DEEPSEA REVERSING THERMOMETER READINGS TO OBTAIN THE THERMOMETRIC DEPTH, CORRECTED FOR GRAVITY VARIATIONS AND FOR THE MEAN DENSITY OF THE OVERLAYING WATER COLUMN IN ANY OCEAN. 3) FITS LEAST SQUARES CURVES TO WIRE LENGTH VS. (WIRE LENGTH MINUS THERMOMETRIC DEPTH) TO DETERMINE THE ACCEPTED DEPTH. 4) CALCULATES SALINITY FROM RAW SALINITY READINGS 5) CALCULATES DISSOLVED OXYGEN CONCENTRATIONS FROM TITRATIONS. REF. A REPORT IUNPUBLISHED MANUSCRIPT) BY NORMA MANTYLA.

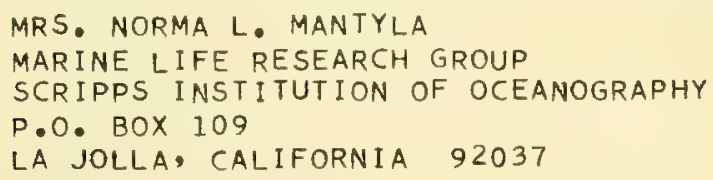

( COPY ON FILE AT NODC) COMPUTER - CDC 3600

A PROGRAM WITH SUBROUTINES TO PROCESS SALINITY-TEMPERATURE-DEPTH DATA RECORDED IN THE FIELD. DESCRIPTION AND LISTINGS IN A BCF SPECIAL SCIENTIFIC REPORT - FISHERIES NO. 588 'PROCESSING OF DIGITAL DATA LOGGER STD TAPES AT THE SCRIPPS INSTITUTION OF OCEANOGRAPHY AND THE BUREAU OF COMMERCIAL FISHERIES, LA JOLLA CALIFORNIA' (JUNE 1969), BY DR. JAMES H. JONES.

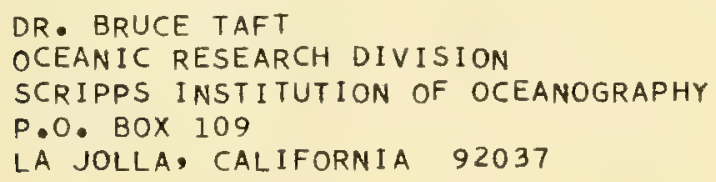

THERMOMETER CORRECTION AND THERMOMETRIC DEPTH

$$
\begin{aligned}
& \text { LAIGUAGE - FORTRAN } \\
& \text { COMPUTER - IBM } 7074
\end{aligned}
$$

( COPY ON FILE AT NODC)

COMPUTES THERMOMETER CORRECTIONS AND THERMOMEIRIC DEPTHS AND THEN PRINTS THIS DATA IN THE FORMAT OF THE U.S. NAVAL OCEANOGRAPHIC LOG SHEET 'A'. IMR NO. 0-9-63 (UNPUBLISHED MANUSCRIPT). AUTHOR-- 5 . C. PORTER •

COMPUTER SYSTEMS DIVISION

NATIONAL OCEANOGRAPHIC DATA CENTER

WASHINGTON, D. C. 20390 
PROCESSES OATA GATHERED WHILE NAVIGATING WITH ANY CIRCULAR AND/OR HYPERBOLIC SYSTEM. EIGHT OPTIONS ARE AVAILABLE PERTAINING TO POSITION CONVERSION, FORM OF INPUT, DATA SMOOTHING, SPECIAL CORRECTIONS, AND INTERPOLATION OF POSITION-DEPENDENT VALUES SUCH AS CONTOUR CROSSINGS. OS NO. 53559.

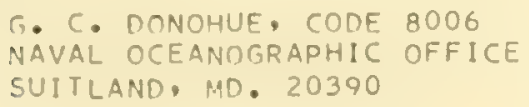

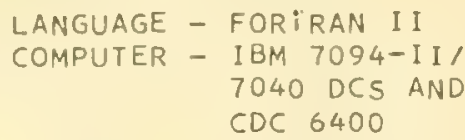

( COPY ON FILE AT NODC)

REDUCES DATA FROM RAW SHIP-BOARD OBSERVATIONS - CORRECTS THERMOMETERS AND COMPUTES THERMOMETRIC DEPTHS, WIRE ANGLE DEPTHS, SALINITIES FROM BRIDGE READINGS, OXYGEN VALUES FROM TITRATIONS, THEN COMPUTES SIGMA-T, OXYGEN SATURATION PERCENT, AND APPARENT OXYGEN UTILUZATION. CORE STORAGE REQUIRED-- 25,335 WORDS FOR MAIN PROGRAM, 2058 WORDS FOR SUBROUTINES. REF. A 150 PAGE REPORT (UWMS-0980, APR 1967) AND TECHNICAL REPORT NO. 181 (MG7-8, JAN 1968), BY EUGENE E. COLLIAS. THERE IS ALSO A MORE LIMITED VERSION FOR THE IBM-1130. REVISED 1969 FOR THE CDC6400 .

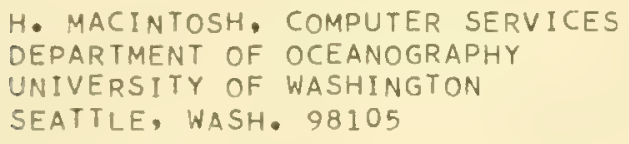

UNDERWAY DATA SYSTEM

PROCESSES DATA COLLECTED FROM UP TO 7 MONITORED SENSORS AND FROM THE AUTOANALYZER WHILE UNDERWAY. INPUT-- PAPER TAPE - RECORDS TAKEN ABOUT ONCE A MINUTE. OUTPUT-- COLLECTED DATA PUNCHED ON CARDS AVERAGED OVER A GIVEN PERIOD. DATA IS THEN USUALLY RUN THROUGH THE IBM CONTOURING SYSTEM (NCS) ANO PLOTTED. DOCUMENTATION-- OPERATING INSTRUCTIONS ONLY

UNIVERSITY OF WASHINGTON DEPARTMENT OF OCEANOGRAPHY 22A OCEANOGRAPHY TEACHING BLDG. ATTN. MRS. HELLA MACINTOSH SEATTLE, WASH. 98105

SALINITY-TEMPERATURE-DEPTH CALCULATIONS

THIS SYSTEM READS AND EDITS PAPER TAPE FROM A BISSETT-BERMAN STD CAST. THE RAW DATA (FREQUENCIES) ARE CONVERTED TO REAL VALUES. INPUT TO PROGRAM-- PUNCHED PAPER TAPE FROM THE HEWLETT-PACKARD DAS. FOUR CHANNELS ARE PUNCHED - SALINITY, TEMPERATURE, SOUND VELOCITY, AND DEPTH. OUTPUT - LISTING OF REAL VALUES, PLOT OF EACH VARIABLE VS. DEPTH, AND A SECTION PLOT OF SALINITY ANDIOR TEMPERATURE VS. DEPTH FOR A MAXIMUM OF 10 STATIONS. DOCUMENTATION-- OPERATING INSTRUCTIONS ONLY.

UNIVERSITY OF WASHINGTON

DEPARTMENT OF OCEANOGRAPHY

22A OCEANOGRAPHY TEACHING BLDG.

ATTN. MRS. HELLA MACINTOSH

SEATTLE, WASH. 98105 
CORRECTS THE SALINITY AS RECORDED BY THE S.T.D. INSTRUMENT FOR ERRORS INTRODUCED BY THE TEMPERATURE GRADIENT, LOWERING SPEED, AND TIME CONSTANT OF THE S.T.D. AUTHOR-- J. HUBERTZ.

TEXAS A AND M UNIVERSITY

COLLEGE OF GEOSCIENCES

DEPARTMENT OF OCEANOGRAPHY

COLLEGE STATION, TEXAS 77843

HYDRO

LANGUAGE - FORTRAN IV-E

COMPUTER - IBM $360 / 50$

PROVIDES I/O FOR HYDROGRAPHIC DATA. USES SUBROUTINES TO CORRECT REVERSING THERMOMETERS AND CALCULATE THERMOMETRIC DEPTH. APPLIES METER WHEEL CORRECTION, AVERAGES TEMPERATURE VALUES, WRITES ALTERNATE VALUES WHERE NECESSARY WRITES APPROPRIATE MESSAGES ON CONDITION OF DATA. WRITES THERMOMETER HISTORY SHOWING WHICH THERMOMETERS MALFUNCTIONED AND WHICH PAIRS OF PROTECTED THERMOMETERS YIELD ALTERNATE VALUES. SUBROUTINES NEEDED-- TEMP, LINT, UTEMP, AZIZ. WRITE-UPS FOR THIS AND OTHER UNIV. OF R. I . PROGRAMS FOR PROCESSING OF HYDROGRAPHIC DATA ARE PRINTED IN A MEMORANDUM, DATED JANUARY 1970, WRITTEN BY R. K. SEXTON.

ROBERT K. SEXTON

NARRAGANSETT MARINE LABORATORY

UNIVERSITY OF RHODE ISLAND

KINGSTON, RHODE ISLAND 02881

TEMP

LANGUAGE - FORTRAN IV-E

COMPUTER - IBM $360 / 50$

SUBROUTINE CALCULATES INDEX AND THERMAL EXPANSION CORRECTIONS FOR PROTECTED REVERSING THERMOMETERS, ASSOCIATES A TOLERANCE WITH EACH THERMOMETER ACCORDING TO RANGE, SETS MESSAGE INDICATORS FOR VARIOUS DATA CONDITIONS. AUXILIARY AND MAIN INDEX CORRECTIONS ARE COMPUTED BY LINEAR INTERPOLATION BETWEEN POINTS IN THE THERMOMETER DATA ARRAY, -PTHRM.- THERMAL EXPANSION CORRECTION IS COMPUTED USING EQUATION (29) PAGE 11, FROM 'ON THE FORMULA FOR CORRECTING REVERSING THERMOMETERS', BY F.K. KEYTE, WHOI, REF. NO. 64-29.

SUBROUTINES NEEDED-- LINT.

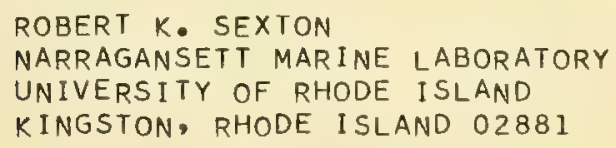

UTEMP

LANGUAGE - FORTRAN IV-E COMPUTER - IBM $360 / 50$

SUBROUTINE CALCULATES INDEX AND THERMAL EXPANSION CORRECTIONS FOR UNPROTECTED THERMOMETERS. IT SELECTS A 'Q' VALUE APPROPRIATE TO THE DEPTH OF REVERSAL. SETS MESSAGE INDICATORS FOR VARIOUS DATA CONDITIONS. AUXILIARY AND MAIN INDEX CORRECTIONS ARE COMPUTED BY LINEAR INTERPOLATION BETWEEN POINTS IN THE THERMOMETER ARRAY, 'UTHRMI. THERMAL EXPANSION CORRECTION IS COMPUTED USING EQUATION ( 8 ), PAGE 8 , FROM ION THE FORMULAS FOR CORRECTING REVERSING THERMOMETERS ', BY F.K. KEYTE, WHOI, REF. NO. 64-29. IF A ' $Q$ ' VALUE FOR THE THERMOMETER IN QUESTION CHANGES WITH DEPTH, WIRE LENGTH IS USED TO COMPUTE THE CORRECT VALUE BY LINEAR INTERPOLATION BETWEEN PRESSURE POINTS. IF THE WIRE LENGTH IS OUTSIDE THE END POINTS, 'Q' VALUES CORRESPONDING TO THE END POINT VALUE ARE USED.

SUBROUTINE NEEDED-- LINT

ROBERT $K$. SEXTON

NARRAGANSETT MARINE LABORATORY 
CALCULATIONS OF CORRECTED TEMPERATURES ANO THERMOMETRIC DEPTHS FROM REVERSING THERMOMETER READINGS. OUTPUT INCLUDES AVERAGE TEMPERATURE, DIFFERENCE BETWEEN CORRECTED TEMPERATURES, AND L-Z VALUES.

BUREAU OF COMMERCIAL FISHERIES BIOLOGICAL LAB.

ATTN. DR. R. A. BARKLEY

P.O. BOX 3830

HONOLULU, HAWAII 96812

THERMOMETER CORRECTION AND THERMOMETRIC DEPTH LANGUAGE - PAL III

COMPUTER - PDP-5, 85

( COPY ON FILE AT NODC)

CORRECTS BOTH PROTECTED AND UNPROTECTED REVERSING THERMOMETERS. DETERMINES THERMOMETRIC DEPTH BY AN ITERATIVE PROCESS. CAN CORRECT A MAXIMUM OF 58 THERMOMETERS. DESIGNED FOR USE ABOARD VESSEL. WRITTEN FOR THE U.S. COAST GUARD BY LT. R.M. OIHAGAN (RET.), DIGITAL EQUIPMENT CORP. MAYNARD, MASS. COPY OF PROGRAM IS DEPOSITED WITH DECUS. REF. U.S. COAST GUARD OCEANOGRAPHIC MANUSCRIPT IOCEANOGRAPHIC COMPUTER PROGRAMS FOR THE PDP-5!, 15 OCT. 1964 (UNPUBLISHED MANUSCRIPT).

DIGITAL EQUIPMENT CORPORATION

MAYNARD, MASSACHUSETTS 01754

HYLOG

LANGUAGE - FORTRAN IV-H

COMPUTER - SDS SIGMA 7

TAKES RAW OCEANOGRAPHIC STATION DATA, CORRECTS THE TEMPERATURES AND FINDS THE DEPTH OF EACH OBSERVATION. INPUT-- CARDS AND 9-TRACK MAGNETIC TAPE IN GENERALIZED FORMAT• CORE STORAGE NEEDED-- 14,452 WORDS.

INFORMATION PROCESSING CENTER

ATTN. MARY HUNT

WOODS HOLE OCEANOGRAPHIC INSTITUTION

WOODS HOLE, MASSACHUSETTS 02543

THRCL

LAIIGUAGE - FORTRAN IV-H
COMPUTER - SDS SIGMA 7

PREPARES A MAGNETIC TAPE FILE OF THERMOMETER CALIBRATION RECORDS TO $B E$ USED WITH PROGRAM 'HYLOG'. THE THERMOMETER CALIBRATIONS ARE INPUT ON CARDS.

INFORMATION PROCESSING CENTER

ATTN. MARY HUNT

WOODS HOLE OCEANOGRAPHIC INSTITUTION

WOODS HOLE, MASSACHUSETTS 02543 
LANGUAGE - FORTRAN

COMPUTER - CDC 3800

PROVIDES I IO MEDIA TO MEDIA CONVERSIONS AND/OR TRANSFERS UNDER COMPUTER OPERATING SYSTEMS CONTROL. THIS PROGRAM PROVIDES A SIMPLE METHOD TO COPY, PRINT, COMPARE, PUNCH, SKIP, OR DESCRIBE RECORDS AND FILES ON AN INPUT SOURCE TO THE CDC 3800 COMPUTER. NRL MEMO. REPORT 1935. AUTHORS-- T. ROZANSKI, J. BURGESS, D. GOSSETT, D. SHANNON.

DORIS E. GOSSETT

RESEARCH COMPUTATION CENTER

MATHEMATICS AND INFORMATION SCIENCES DIVISION

NAVAL RESEARCH LABORATORY, WASHINGTON, D. C. 20390

NELEDIT

LANGUAGE - FORTRAN

COMPUTER - CDC 3800

EDITS CARDS OR CARD IMAGES UNDER OPERATING SYSTEM CONTROL. PROVIDES A SIMPLE METHOD OF RESEQUENCING, SEQUENCING, PRINTING, INSERTING, DELETING AND REPLACING CARD IMAGES WHICH EXIST ON AN INPUT SOURCE TO THE COMPUTER. NRL MEMO. REPORT 1936. AUTHORS-- J. BURGESS, D. GOSSETT,

D. SHANNON.

DORIS E. GOSSETT

RESEARCH COMPUTATION CENTER

MATHEMATICS AND INFORMATION SCIENCES DIVISION

NAVAL RESEARCH LABORATORY, WASHINGTON, D. C. 20390

JOB EDIT FOR L-Z PROGRAM

LANGUAGE - AUTOCODER

COMPUTER - IBM 1401

( COPY ON FILE AT NODC)

USES OUTPUT TAPE FROM TEMPERATURE AND DEPTH PROGRAM AS INPUT. AUTHOR-D.L. SHAFFER.

UNIVERSITY OF MIAMI

MARINE LABORATORY

COMPUTING CENTER

1 RICKENBACKER CAUSEWAY

VIRGINIA KEY, MIAMI, FLORIDA

A TAPE INPUT AND OUTPUT SUBROUTINE

LANGUAGE - AUTOCODER

( COPY ON FILE AT NODC)

THE 'TAPIO! (TAPE INPUT AND OUTPUT) PROGRAM IS DESIGNED TO BE CALIED

BY FORTRAN. IT CAN BE USED TO OPERATE DATA TAPES MUCH FASTER THAN OTHERWISE POSSIBLE, MAKING USE OF THE FEATURE OF ISIMULTANEITY'. ALSO, IT WILL CALL AN IEDIT, PROGRAM AS REQUIRED, FOR INPUT AND OUTPUT PROCEDURES. USING TAPIO MAKES IT NECESSARY TO WRITE YOUR OWN EDIT PROGRAM. REF. IMR NO. M-2-64, JAN 1965 (UNPUBLISHED MANUSCRIPT). AUTHOR

- PHILLIP J. LAUTENSCHLAGER.

DATA SYSTEMS CENTER, CODE 083

NAVAL OCEANOGRAPHIC OFFICE

SUITLAND, MD. 20390

( COPY ON FILE AT NODC) 
KATHLEEN A. JENNINGS, WHICH DESCRIBES THIS AND OTHER PROGRAMS AND PROCEDURES USED AT THE NAVAL OCEANOGRAPHIC OFFICE IN THE LORAN TABILE EDITING PROCESS. FURTHER INFORMATION MAY BE OBTAINED FROM THE FIELO MANAGEMENT AND DISSEMINATION DEPT • (CODE 44), OR THE AUTHOR •

NAVIGATIONAL SCIENCE DIV., CODE 5320

TECHNICAL PRODUCTION DEPT.

NAVAL OCEANOGRAPHIC OFFICE

SUITLAND, MD. 20390

SOUND SPEED EOIT

LANGUAGE - FORTRAN

COMPUTER - IBM 7074

TAKES NODC DATA CARDS HAVING TIME SERIES SOUND SPEED DATA, ADDS ON A BOTTOM PART BECAUSE THE TIME SERIES DATA DOES NOT GO TO THE BOTTOM OF THE WATER COLUMN, AND REARRANGES THE DATA TO MAKE IT ACCEPTABLE TO

THE RAY TRACE PROGRAM OF CISNEY. OS NO. 53817• AUTHOR-- R・R. GLEASON.

EXPLORATORY OCEANOGRAPHY DIV., CODE 7200

NAVAL OCEANOGRAPHIC OFFICE

SUITLAND, MD. 20390

CARDS

LANGUAGE - FORTRAN IV-E

COMPUTER - IBM $360 / 50$

CONVERTS PUNCHED OUTPUT FROM 'SIGMAT' TO INPUT FOR 'HEIGHT'.

ROBERT $K$. SEXTON

NARRAGANSETT MARINE LABORATORY

UNIVERSITY OF RHODE ISLAND

KINGSTON, RHODE ISLAND 02881

DEPTHS

LANGUAGE - FORTRAN IV-E

COMPUTER - IBM $360 / 50$

CONVERTS PUNCHED OUTPUT FROM 'HYDRO' TO INPUT FOR 'SIGMAT'.

ROBERT K. SEXTON

NARRAGANSETT MARINE LABORATORY

UNIVERSITY OF RHODE ISLAND

KINGSTON, RHODE ISLAND 02881

RDTHRM

LANGUAGE - FORTRAN IV-E

COMPUTER - IBM $360 / 50$

READS THERMOMETER DATA AS IT IS READ BY 'HYDRO' AND WRITES OUT THE DATA IN A FORMAT SUITABLE FOR CHECKING.

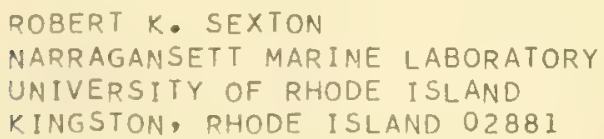

DATA

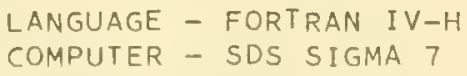

SUBROUTINE READS OCEANOGRAPHIC STATION DATA CARDS AND RETURNS THE INFORMATION CONTAINED THEREIN TO THE USER, ONE STATION FOR EACH CALI.

INFORMATION PROCESSING CENTER

ATTN. MARY HUNT

WOOOS HOLE OCEANOGRAPHIC INSTITUTION

WOOOS HOLE, MASSACHUSETTS 02543 
PROVIDES SEVERAL METHODS BY WHICH DATA STORED IN WHOI STANDARD FORMAT MAY BE EDITED AND TESTED. OUTPUT IS THE CORRECTED VERSION OF THE DATA ON 9-TRACK MAG. TAPE.

INFORMATION PROCESSING CENTER

ATTN. JOHN A. MALTAIS

WOODS HOLE OCEANOGRAPHIC INSTITUTION

WOODS HOLE, MASSACHUSETTS 02543

\section{BATHYTHERMOGRAPH OUTPUT}

LANGUAGE - SPS

( COPY ON FILE AT NODC)

COMPUTER - IBM 1401

TAPE TO CARD/PRINT EDITING PROGRAM. BLOCKED INPUT WITH MSQ OR CRUISE SEQUENCE FORMS CONTROL. USES TAPE SEARCH, SELECTION AND DUPLICATION. OS NO. 52291. AUTHOR-- J.C. JENSON.

COMPUTER SYSTEMS DIVISION

NATIONAL OCEANOGRAPHIC DATA CENTER

WASHINGTON, D. C. 20390

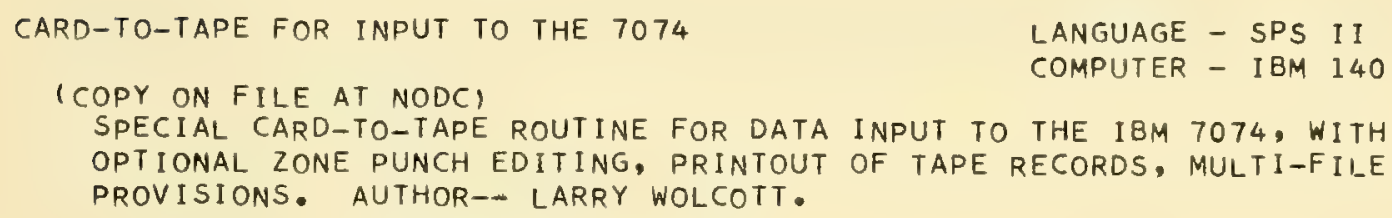

OCEANS II REPORT GENERATOR

LANGUAGE - SPS

( COPY ON FILE AT NODC)

COMPUTER - IBM 1401

USED FOR HIGH SPEED PREPARATION OF OCEANS II OUTPUT FOR DATA RECORD

PUBLICATION• (NOTE-- CODC IS NOW USING A LATER VERSION OF THIS DECK.)

CANADIAN OCEANOGRAPHIC DATA CENTRE

615 BOOTH STREET

OTTAWA, CANADA

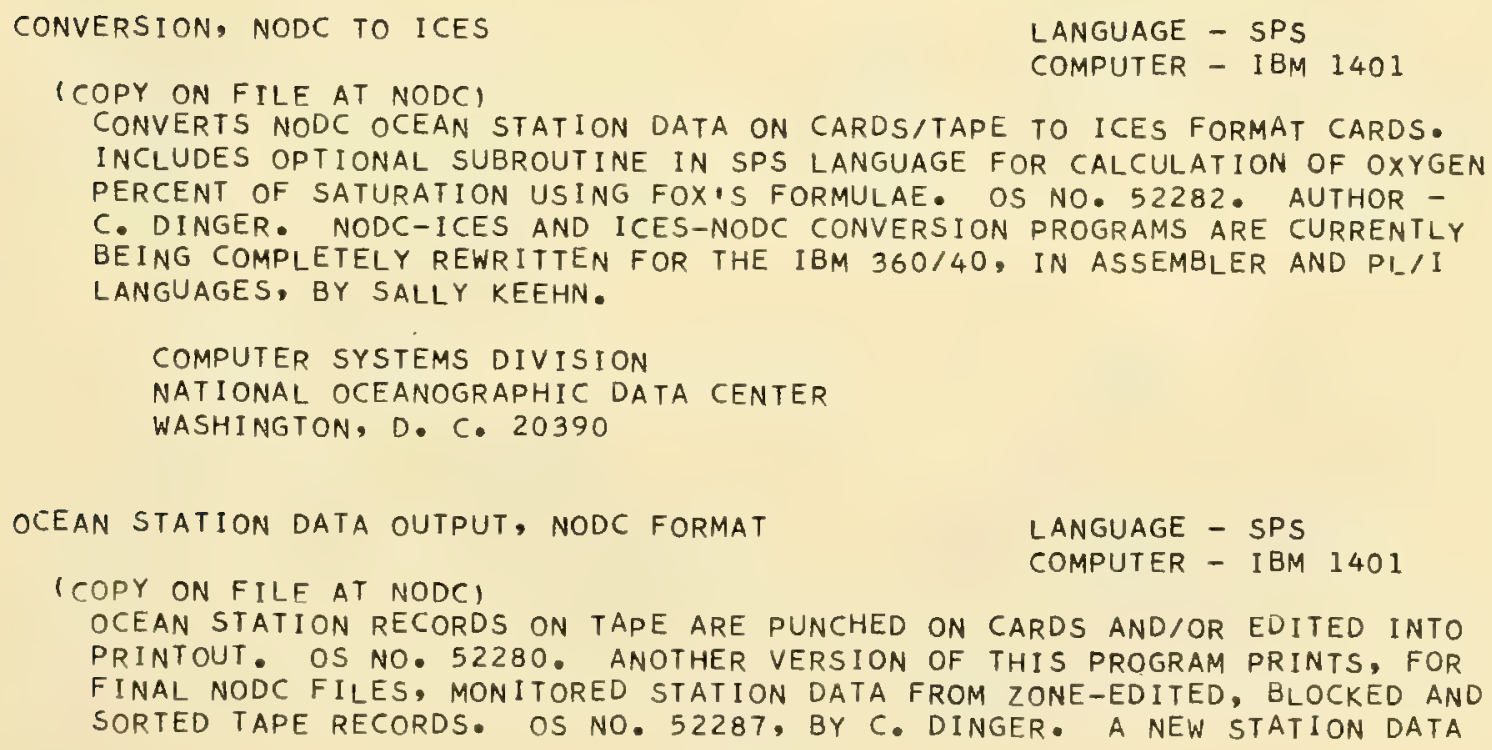


OUTPUT PROGRAM IS AT PRESENT BEING WRITTEN FOR THE IBM 360/40, IN PLII LANGUAGE, BY JOHN MCHUGH.

COMPUTER SYSTEMS DIVISION

NATIONAL OCEANOGRAPHIC DATA CENTER

WASHINGTON, D. C. 20390

STATION DATA CONVERSION, CODC TO NODC

LANGUAGE - SPS

( COPY ON FILE AT NODC)

COMPUTER - IBM 1401

CANADIAN OCEANOGRAPHIC DATA CENTRE STATION DATA IS TRANSFERRED OR CONVERTED TO THE NEW NODC FORMAT. CODC CRUISE MASTER CARDS MUST BE PRECEDED BY A NODC LEADER CARD. OS NO. 52212. AUTHOR - RUDI SAENGER.

COMPUTER SYSTEMS DIVISION

VATIONAL OCEANOGRAPHIC DATA CENTER

WASHINGTON, D. C. 20390 
COMPUTES SPECTRAL RADIANCE OF A BLACKBODY RADIATOR USING ONE DEGREE INCREMENTS OF TEMPERATURE AND 0.05 MICROMETER INCREMENTS OF WAVELENGTH. INPUT PARAMETERS ARE TEMPERATURE AOD WAVELENGTH.

APPLIED OCEANOGRAPHY BRANCH - CODE 8310 NAVAL RESEARCH LABORATORY WASHINGTON, D. C. 20390

BLACKBODY RADIANCE

LANGUAGE - FORTRAN COMPUTER - CDC 3809

COMPUTES RADIANCE OF A BLACKBODY RADIATOR IN A SPECIFIED WAVELENGTH INTERVAL USING ONE DEGREE INCREMENTS OF TEMPERATURE AND 0.05 MICROMETER INCREMENTS OF WAVELENGTH. INPUT PARAMETERS ARE TEMPERATURE AND WAVELENGTH.

APPLIED OCEANOGRAPHY BRANCH - CODE 8310 NAVAL RESEARCH LABORATORY

WASHINGTON, D. C. 20390

LONG WAVE RADIATION

LANGUAGE - FORTRAN IV COMPUTER - IBM $360 / 65$

CALCULATES RADIATION VALUES FOR THE SUOMI-KUHN RADIOMETER. INPUT DATA FROM THE TRADE WIND ZONE OCEANOGRAPHY PROGRAM RADIATION CARDS.

BUREAU OF COMMERCIAL FISHERIES

2570 DOLE STREET

HONOLULU, HAWAII 96812

OBSERVATION DRAPING (GRAVITY)

LANGUAGE - FORTRAN

COMPUTER - IBM 7074

REDUCES OBSERVATION DATA TAKEN WITH LACOSTE-ROABERG SEA/AIR OR SUBMARINE GRAVIMETERS TO OBSERVED GRAVITY VALUE AND FREE-AIR ANOMALY. INTERPOLATES GEOGRAPHIC POSITION FROM SMOOTHED FIX, COURSE, AND SPEED. GENERATES BC CHART NO. AND $X, Y$ COORDINATES FOR MERCATOR PROJECTION FOR EACH STATION. OS NO. 53543. AUTHOR-- R.K. LATTIMORE.

GRAVITY DIVISION, CODE 83

NAVAL OCEANOGRAPHIC OFFICE

SUITLAND, MD. 20390

REDUCTION AND DISPLAY OF DATA ACQUIRED AT SEA

LANGUAGE - FORTRAN II

COMPUTER - IBM 1130

(COPY ON FILE AT NODC)

A SYSTEM OF PROGRAMS (NAVIGATION, GRAVITY, TOPOGRAPHY, MAGNETICS) FOR THE REDUCTION, STORAGE AND DISPLAY OF UNDERWAY DATA ACQUIRED AT SEA. THE COMPUTER INSTALLATION CONSISTS OF AN IBM 1130 AND INCLUDES RANDOM ACCESS DISK CARTRIDGES AND AN ON-LINE CALCOMP 30 IN. PLOTTER. A LARGE NUMBER OF THE PROGRAMS UTILIZE NAVIGATION POINTS TOGETHER WITH RAW DIGITIZED GEOPHYSICAL DATA PRESENTED AS A TIME SERIES, WHERE THE DIFFERENT DATA MAY BE READ AT UNEQUAL TIME INTERVALS. REF. TECH. REPORT NO. 1 (AUGUST 1969,348 P.) BY MANIK TALWANI. 
(COPY ON FILE AT NODC)

CALCULATES THE VERTICAL COMPONENT OF GRAVITATIONAL ATTRACTION OF TWO-

DIMENSIONAL BODIES OF ARBITRARY SHAPE BY APPROXIMATING THEM TO MANY-

SIDED POLYGONS. THE TECHNIQUE IS FROM TALWANI, WORZEL, AND LANDISMAN

IN JGR, VOL. 64 NO. 1, 1959. OUTPUT-- THE GRAVITY VALUES ARE PRINTED

IN TABLES, AND THE CALCULATED PROFILE AND THE OBSERVED PROFILE IF ONE

EXISTS ARE PLOTTED ON THE LINE PRINTER IN EITHER A PAGE SIZE PLOT OR

AN EXTENDED PLOT WITH THE X-AXIS RUNNING DOWN THE PAGE. PROGRAM CON-

TAINS OPTION OF UNITS IN MILES, KILOFEET, OR KILOMETERS. THE PROGRAM

NO. IS W9206 (MAY, 1968).

\author{
U. S. GEOLOGICAL SURVEY \\ COMPUTER CENTER DIVISION \\ ATTN. RALPH EICHER, CHIEF \\ BRANCH OF SCIENTIFIC APPLICATIONS \\ WASHINGTON, D. C. 20242
}

PROFILE CARD-TO-TAPE FOR GEOPAC

LANGUAGE - FORTRAN I V-H

COMPUTER - IBM $360 / 65$

( COPY ON FILE AT NODC)

USED TO PUT DATA, USUALLY PROFILE DATA, PUNCHED ON CARDS ONTO MAGNETIC TAPE FOR SUBSEQUENT PROCESSING BY OTHER PROGRAMS IN A PACKAGE OF PRO-

GRAMS FOR TWO-DIMENSIONAL GRAVITY AND MAGNETIC CALCULATIONS. OPTIONS

IN THE PROGRAM ALLOW FOR THE PRELIMINARY OPERATIONS OF SCALING, SHIFTING, OR DETRENDING THE DATA. PROFILES MAY ALSO BE CONCATENATED TO

COMBINE SEVERAL DATA SETS AS ONE. PROGRAM NO - W9325, BY RALPH EICHER.

U. 5. GEOLOGICAL SURVEY

COMPUTER CENTER DIVISION

ATTN. RALPH EICHER, CHIEF

BRANCH OF SCIENTIFIC APPLICATIONS

WASHINGTON, D. C. 20242

20 MAGNETIC ANOMALIES

\author{
LANGUAGE - FORTRAN \\ COMPUTER - IBM 1800 SYS
}

COMPUTES HORIZONTAL AND VERTICAL AND TOTAL MAGNETIC ANOMALIES ARISING FROM PRISMS OF ARBITRARY CROSS-SECTION AND MAGNETISATION AND INFINITE IN LENGTH. A VERSION FOR THE ATLAS I IS ALSO IN FORTRAN. N.I.O. PROGPAM 102, BY E. PALETHORPE AND J. CREASE. REF. N•I.O. INTERNAL REPORT NO. N.10, NOV 1968 .

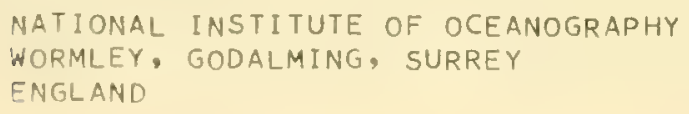

\title{
COMPUTATION AND PLOTTING OF MAGNETIC ANOMALIES
} AND GRADIENTS

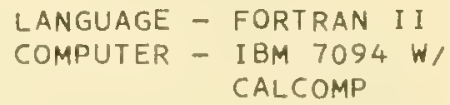

(COPY ON FILE AT NODC)

COMPUTES THE ANOMALY PROFILES FOR TOTAL FIELD, HORIZONTAL AND VERTICAL COMPONENTS, FIRST AND SECOND VERTICAL DERIVATIVES AND FIRST AND SECOND HOR IZONTAL DERIVATIVES OVER A UNIFORMLY MAGNETIZED TWO-DIMENSIONAI_ POLYGON OF IRREGULAR CROSS-SECTION. OUTPUT MAY BE PRINTED OR PLOTTED. REF. 'POTENTIAL APPLICATIONS OF MAGNETIC GRADIENTS TO MARINE GEOPHYSICS BY WILLIAM E. BYRD, JR., JUNE 1967. PROGRAM MODIFIED AND EXPANDEO FROM TALWANI AND HEIRTZLER (1964). 
AVERAGES THE RADIATION READINGS FROM THE EPPLEY PYRHELIOMETER AND BECKMAN-WHITLEY RADIOMETER FOR EVERY 15 MINUTES. CONVERTS FROM MV TO LANGLEYS/MIN. AND CALCULATES NET RADIATION FROM BOTH INSTRUMENTS. A MODIFICATION OF THIS PROGRAM WAS MADE TO INCLUDE A THORNTHWAITE NET RADIOMETER. ORIGINAL PROGRAM BY S.M. LAZANOFF REWRITTEN BY MARY E. MYERS.

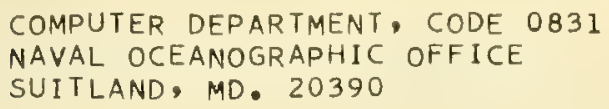

SEAMOUNT MAGNETIZATION

$$
\begin{aligned}
& \text { LANGUAGE - FORTRAN } \\
& \text { COMPUTER - IBM } 7074
\end{aligned}
$$

COMPUTES THE MAGNITUDE AND DIRECTION OF MAGNETIZATION OF A UNIFORMLY MAGNETIZED BODY FROM ITS SHAPE AND MAGNETIC INTENSITY. OS NO. 53533. AUTHOR-- G. VAN VOORHIS.

MAGNETICS DIVISION, CODE 8200

NAVAL OCEANOGRAPHIC OFFICE

SUITLAND, MD. 20390

VAM INTERPOLATION I I

LANGUAGE - FORTRAN

COMPUTER - IBM 7074

COMPUTES INCLINATION, MAGNETIC HEADING, RELATIVE BEARING, AND DECI_INATION. OUTPUT CONTAINS TRACK, DATE, AIRCRAFT TIME, POSITION, DECIINATION, DIP, HORIZONTAL INTENSITY (FORCE), ALTITUDE, AND GROUND SPEED FOR EACH FIVE MINUTES OF TIME. OS NO. 35032, BY W. H. HANCOCK.

NAVAL OCEANOGRAPHIC OFFICE

SUITLAND, MD. 20390

SEISMIC SLOPING LAYER COMPUTATION

LANGUAGE - FORTRAN II

COMPUTER - IBM 709

GIVES TRUE VELOCITIES AND THICKNESSES OF LAYERS FOR SEISMIC REFRACTION PROFILES. INPUT ARE HORIZONTAL AND AVERAGE VERTICAL WATER VELOCITIES AND APPARENT ONE-WAY VELOCITIES OF SUBSURFACE INTERFACES DERIVED FROM TRAVEL-TIME GRAPHS. COMPUTATION FOLLOWS GEOMETRIC METHOD FOR PI_ANE SEISMIC WAVES UTILIZING SNELL'S LAW. AUTHOR-- JOHN ANTOINE.

TEXAS A AND M UNIVERSITY

COLLEGE OF GEOSCIENCES

DEPARTMENT OF OCEANOGRAPHY

COLLEGE STATION, TEXAS 77843

TIME TERM, SEISMIC REFRACTION INTERPRETATION

( COPY ON FILE AT NODC)

ANALYZES A SET OF DATA THAT APPEARS TO HAVE BEEN GENERATED BY A HEAD WAVE SYSTEM PROPAGATING ALONG A PARTICULAR BOUNDARY. REAOS THE STANDARD TRAVEL-TIME DATA CARDS (CARNEGIE INST, WASH, DTM). TIME TERMS ARE CALCULATED FOR THE BEST LEAST-SQUARE FITTING VELOCITY. IN ADDITION, CALCULATES THE STANDARD DEVIATION OF THE SOLUTION AS A FUNCTION OF VELOCITY AND EXAMINES THE MATRIX OF RESIDUALS FOR FREQUENCY AND DEPENDENCE UPON DISTANCE. THESE FEATURES OF THE MATRIX ARE PRESENTED IN GRAPH FORM. AUTHOR - M.J. BERRY.
LANGUAGE - FORTRAN IV COMPUTER - IBM 7094 
UNIVERSITY OF TORONTO

DEPARTMENT OF PHYSICS

GEOPHYSICS LABORATORY

ATTN. DR. G. F. WEST

TORONTO 5 ONTARIO

\section{*-* SEDIMENT ANALYSIS AND MECHANICS ****}

\section{GEOLOGICAL SAMPLE CONVERSION}

LANGUAGE - FORTRAN

(COPY ON FILE AT NODC)

COMPUTER - IBM 7074

CONVERTS-EDITS TO NODC FORMAT FOR CARDS, DATA ON SAMPLES COLLECTED OR STUDIED AS PART OF THE JOINT WOODS HOLE O.I. - U.S. GEOLOGICAL SUR JEY, ATLANTIC CONTINENTAL MARGIN PROGRAM. INCLUDES AN INDICATOR OF DEPTH RANGE VIA TABLE LOOK-UP. AND COMPUTATIOH OF MARSDEN SQUARE. OS NO. 52231. AUTHOR-- R. VAN WIE.

COMPUTER SYSTEMS DIVISION

NATIONAL OCEANOGRAPHIC DATA CENTER

WASHINGTON, D. C. 20390

MASS PHYSICAL, PROPERTIES

LANGUAGE - FORTRAN

COMPUTER - IBM 7074

COMPUTES THE RESULTS OF ENGINEERING ANALYSES IN THE GEOLOGICAL LAB. THESE ANALYSES INCLUDE DENSITY, SPECIFIC GRAVITY, VOID RATIO, ATTERBURG LIMITS, COHESION. COMPRESSIVE STRENGTH, CONSOLIDATION, MOISTURE CONTENT. ETC. OS NO. 59202.

OCEAN SURYEYS, CODE 9200

NAVAL OCEANOGRAPHIC OFFICE

SUITLAND, MD. 20390

COMPUTES THE FREQUENCY OF THE GRAIN SIZE DISTRIBUTION AND THE STATISTICAL PARAMETERS. AND RECORDS PERTINENT FIELD DATA AND COMPOSITIONAL DATA DETERMINED IN THE LABORATORY. THE PROGRAM WILL HANDLE DATA FROM AN INDEFINITE NUMBER OF CORE SAMPLES. OUTPUT PRINTED IN TABULAR FORM. REF. INFORMAL MANUSCRIPT IM NO. 66-11, AUG. 1966, 'SEDIMENT SIZE COMPUTER PROGRAM? AUTHORS-- DR. J.B. RUCKER AND R.A. STEWART, EXPLORATORY OCEANOGRAPHY DIV. CODE 7220. FURTHER INFORMATION MAY BE OBTAINED THROUGH DISSEMINATION DEPARTMENT, CODE 44, OR THE AUTHORS.

NAVAL OCEANOGRAPHIC OFFICE

SUITLAND. MD. 20390

GRAIN SIZE

LANGUAGE - FORTRAN II

COMPUTER - GE 225

A COMPUTER PROGRAM FOR GRAIN-SIZE DATA, BY JOHN SHLEE AND JACQUELINE WEBSTER, 1965, WOODS HOLE OCEANOGRAPHIC INSTITUTION REF. NO. 65-42 (UNPUBLISHED MANUSCRIPT). THIS PROGRAM AND SEVERAL OTHERS FOR SEDIMENT DATA PROCESSING ARE PRODUCTS OF THE U.S. GEOLOGICAL SURVEY'S MARINE GEOLOGY AND HYDROLOGY PROGRAM. 
COMPUTES THE MEAN, STANDARD DEVIATION, SKEWNESS, AND KURTOSIS BY THE METHOD OF MOMENTS FOR SIZE DISTRIBUTION OF PARTICLES AS DETERMINED BY STANDARD SEDIMENT ANALYSIS, THE FRACTION OF THE TOTAL SAMPLE IN EACH SIZE CLASS, AND THE FRACTION OF SAND-SIZE MATERIAL COMPOSED OF UP TO 10 DIFFERENT COMPONENTS. AUTHORS-- J.W. PIERCE, U.S. NATIONAL MUSEUM, AND D.I. GOOD, KANSAS GEOL. SURVEY. REF. SPECIAL DISTRIBUTION PUBLICATION $28(1965)$. RUNNING TIME-- LESS THAN 5 HOURS FOR 400 SAMPLES.

DR. DANIEL F. MERRIAM, EDITOR, COMPUTER CONTRIBUTIONS KANSAS GEOLOGICAL SURVEY

COMPUTER APPLICATIONS LABORATORY

THE UNIVERSITY OF KANSAS

LAWRENCE, KANSAS 66045

SEDIMENT DATA

\author{
LANGUAGE - FORTRAN II \\ COMPUTER - IBM 709 AND \\ CDC 6400
}

ALL SEDIMENT DATA COMPUTATIONS, SUCH AS MEANS AND STANDARD DEVIATIONS OF TEXTURE, TOTAL TEXTURE, CARBONATE AND NON-CARBONATE FRACTIONS, AS WELL AS ORGANIC NITROGEN AND CARBON DATA HANDLING. PROGRAM REVISED IN 1964. AUTHOR-- PROF. H.G. GOODELL.

\author{
DEPARTMENT OF GEOLOGY \\ FLORIDA STATE UNIVERSITY \\ TALLAHASSEE, FLORIDA 32306
}

ENGINEERING INDEX PROPERTIES OF CORE SAMPLES

LANGUAGE - FORTRAN II-D

(COPY ON FILE AT NODC)

COMPUTER - IBM 1620 II

REDUCES DATA AND TABULATES RESULTS FOR TESTS ON BULK WET DENSITY, VANE SHEAR STRENGTHS, ORIGINAL WATER CONTENT, LIQUID LIMIT, PLASTIC LIMIT, ANO SPECIFIC GRAVITY OF SOLIDS. IN ADDITION, FROM THE ABOVE RESUITS, OTHER INDEX PROPERTIES ARE SIMULTANEOUSLY COMPUTED AND TABULATED. THE OUTPUT TABLE LISTS RESULTS IN COLUMNS REPRESENTING EACH DEPTH SEGMENT ANALYZED. PUBLISHED AS AN NCEL TECHNICAL REPORT, REF. NO. R-566 (FEB 1968,165 P), BY MELVIN C. HIRONAKA.

U.S. NAVAL CIVIL ENGINEERING LABORATORY

PORT HUENEME, CALIFORNIA 93041

GRAIN SIZE ANALYSIS WITH DIRECT PLOTTING

LANGUAGE - FORTRAN II-D COMPUTER - IBM 1620 II

(COPY ON FILE AT NODC)

INPUT DATA ARE SAMPLE IDENTIFICATION, SAMPLE WEIGHTS, HYDROMETER READINGS, AND SIEVE READINGS. OUTPUT ON IBM 1627 MODEL I PLOTTER IS A PARTICLE SIZE DISTRIBUTION CURVE. ANOTHER PROGRAM WRITTEN FOR OUTPUT ON CARDS OF A TABLE WITH PROPER HEADINGS. AND VALUES FOR PARTICLE DIAMETERS AND PERCENT FINER BY WEIGHT. REF. NCEL REPORT NO • R-566, BY MELVIN C. HIRONAKA.

U.S. NAVAL CIVIL ENGINEERING LABORATORY

PORT HUENEME, CALIFORNIA 93041

CARBONATE - ORGANIC CARBON ANALYSIS OF SEDIMENTS

LANGUAGE - FORTRAN II-D

( COPY ON FILE AT NODC)

COMPUTER - IBM 1620 II

REDUCES DATA FROM THE CARBON DETERMINATOR AND TABULATES RESULTS OF THE ANALYSIS OF DEEP OCEAN SEDIMENTS FOR CARBONATE AND ORGANIC CARBON PERCENTAGES. OUTPUT IN SAME FORMAT AS IN PROGRAM FOR ENGINEERING INDEX PROPERT IES, TO WHICH THE OUTPUT FROM THIS PROGRAM IS ADDED. PROGRAM LISTINGS AND WRITEUPS INCLUDED IN AN NCEL REPORT, NO. R-566, BY MELVIN HIRONAKA. 
(COPY ON FILE AT NODC) REDUCES DATA AND PLOTS SHEAR STRESS VERSUS SHEAR DISPLACEMENT WITH APPROPRIATE HEADINGS AND LABELS, USING IBM MODEL I PLOTTER. ANOTHER PROGRAM, IDIRECT SHEAR TEST, USES THE SAME DATA FORMATS BUT PRESENTS THE RESULTS IN THE FORM OF TABULATIONS RATHER THAN PLOTS. REF. NCEL REPORT R-566. AUTHOR - MELVIN C. HIRONAKA.

U.S. NAVAL CIVIL ENGINEERING LABORATORY

PORT HUENEME, CALIFORNIA 93041

TRIAXIAL COMPRESSION TEST WITH DIRECT PLOTTING

( COPY ON FILE AT NODC) REDUCES THE DATA FROM TRIAXIAL COMPRESSION TESTS AND PLOTS STRESS VS. STRAIN WITH HEADINGS FOR SAMPLE IDENTIFICATION, LATERAL PRESSURE, ETC. ANOTHER PROGRAM REDUCES THE SAME RAW DATA AND PRESENTS THE RESULTS IN THE FORM OF TABULATIONS, ONE FOR EACH TEST. LISTINGS AND DESCRIPTIONS FOR BOTH PROGRAMS INCLUDED IN AN NCEL REPORT, REF. NO. R-566, BY M.C. HIRONAKA.

U.S. NAVAL CIVIL ENGINEERING LABORATORY PORT HUENEME, CALIFORNIA 93041 LANGUAGE - FORTRAN II D
COMPUTER - IBM 1620 II
CONSOLIDATION TEST (E VS. LOG TIME PLOT)

( COPY ON FILE AT NODC)

REDUCES THE DATA OBTAINED FROM THE CONSOLIDATION TEST READINGS. INPUT INCLUDES SAMPLE IDENTIFICATION AND CHARACTERISTICS, AND TEST CHARAC TERISTICS. THE OUTPUT FROM THIS PROGRAM IS IN TWO FORMS $\rightarrow$ PLOTS AND PUNCHED CARDS. THE LOG OF TIME IS PLOTTED VS. THE VOID RATIO. THE CARDS ARE USED AS INPUT TO THE NEXT CONSOLIDATION TEST PROGRAM.

U.S. NAVAL CIVIL ENGINEERING LABORATORY

PORT HUENEME, CALIFORNIA 93041
LANGUAGE - FORTRAN II -D COMPUTER - IBM 1620 II

LOG P PLOTS)

(COPY ON FILE AT NODC)

DEVELOPES PLOTS FOR VOID RATIO VS. LOG OF PRESSURE AND COEFFICIENT OF CONSOLIDATION VS. LOG OF PRESSURE. THE INPUT TO THIS PROGRAM CONSISTS OF THE OUTPUT CARDS FROM THE PREVIOUS PROGRAM TOGETHER WITH THE VALUES OF VOID RATIO AND PRESSURE AT 100 0/O CONSOLIDATION AND THE TIME AND VOID RATIO AT 50 O/O CONSOLIDATION. THESE DATA WERE OBTAINED FROM THE PLOTS OF VOID RATIO VS. LOG OF TIME IN ACCORDANCE WITH THE TERZAGHI CONSOLIDATION THEORY. EXAMPLES OF INPUT AND OUTPUT, WITH PROGRAM DESCRIPTIONS AND LISTINGS, INCLUDED IN NCEL REPORT R-566 (FEB 68, 165 P) BY MELVIN C. HIRONAKA.

U.S. NAVAL CIVIL ENGINEERING LABORATORY

PORT HUENEME, CALIFORNIA 93041

PERMEABILITY TEST WITH DIRECT PLOTTING

LANGUAGE - FORTRAN II-D

COMPUTER - IBM 1620 II

(COPY ON FILE AT NODC)

REDUCES TEST DATA AND PLOTS CURVE OF PERMEABILITY VERSUS TIME WITH APPROPRIATE HEADINGS AND LABELS, USING IBM 1627 MODEL I PLOTTER - THE PLOTTING SCALE IS A VARIABLE INCORPORATED IN THE PROGRAM, SINCE PERMEABILITY VALUES FOR FINE-GRAINED SOILS VARY THROUGHOUT A WIDE RANGE. REF. NCEL REPORT R-566. AUTHOR-- MELVIN C. HIRONAKA. 
U.5. NAVAL CIVIL ENGINEERING LABORATORY

PORT HUENEME, CALIFORNIA 93041

SETTLEMENT ANALYSIS

(COPY ON FILE AT NODC)

ESTIMATES SETTLEMENT VALUES FROM LABORATORY TEST RESULTS, FOR DEEP OCEAN FOUNDATION INVESTIGATIONS. INPUT ARE SEDIMENT PROPERTIES AND STRUCTURE CHARACTERISTICS. OUTPUT IS A TABLE LISTING TOTAL SETTLEMENT, FOOTING DIMENSIONS, STRUCTURE LOAD, CHANGE IN THICKNESS OF INCREMENTAL LAYERS AT CORRESPONDING DEPTH IN SEDIMENT, INITIAL STRESS, AND CHANGE IN STRESS. EQUATIONS, ETC., DESCRIBED IN AN NCEL REPORT, NO. R-566, BY MELVIN C. HIRONAKA.

U.S. NAVAL CIVIL ENGINEERING LABORATORY

PORT HUENEME, CALIFORNIA 93041

SUMMARY PLOTS

(COPY ON FILE AT NODC)

PLOTS THE RESULTS FROM THE LABORATORY ANALYSIS OF CORE SAMPLES. THE INPUT DATA ARE THE OUTPUT RESULTS ON CARDS FROM THE PREVIOUS PROGRAMS AND MISCELLANEOUS ANALYSES. SINCE THE LINK SYSTEM OF PROGRAMMING IS USED, THE ITEMS TO BE PLOTTED CAN BE INCREASED OR DECREASED WITH SLIGHT MODIFICATIONS, DEPENDING ON THE USER'S REQUIREMENTS. OUTPUT IS A SEQUENCE OF PLOTS. THE DEPTH INTO THE SEDIMENT COLUMN IS PLOTTED WITH REFERENCE TO THE ORDINATE, AND THE VARIOUS PROPERTIES ALONG THE ABSCISSA ON VARIABLE SCALES. REF. A TECHNICAL REPORT NO. R-566 ICOMPUTER REDUCTION OF DATA FROM ENGINEERING TESTS ON SOILS AND OCEAN SEDIMENTS'. AUTHOR-- MELVIN C. HIRONAKA, NCEL.

U.S. NAVAL CIVIL ENGINEERING LABORATORY

PORT HUENEME, CALIFORNIA 93041

BKGEOL (SEDIMENT ANALYSIS STATISTICS)

(COPY ON FILE AT NODC)

MODIFICATION OF U.W. ROUTINE 213 FOR THE 709 PREPARED IN FORTRAN II BY E.E. COLLIAS AND M.R. RONA (REF. TECH. REPORT NO. 87, 1963). ACCEPTS INPUT DATA IN A MORE ELEMENTARY FORM THAN PREVIOUS PROGRAM AND THE ANALYST MAKES NO CALCULATIONS. INCLUDES PROVISION FOR COMPENSATING FOR VARIATIONS IN DENSITY, TEMPERATURE, AND ERRORS IN PIPETTING DEPTH AND, OR TIME. OUTPUT IS A LIST OF INPUT DATA, LIST OF COMPONENT, RATIO, TRASK, INMAN, AND FOLK AND WARD STATISTICS, SHEPARD DIAGRAM INFORMATION AND PASSEGA'S C-M VALUES. OPTIONAL PUNCH CARD OUTPUT. PROGRAM DATE-- MAY 1966. AUTHOR-- WILLIAM ANIKOUCHINE, JORG, ESSA. IA PIOOT ROUTINE WAS PREPARED TO GRAPH PERCENTILE VS PHI-SIZES FROM THE RESULTS OF THE MAIN PROGRAM.।

W. ANIKOUCHINE, RES. ASSOCIATE

JORG-ESSA, CIO DEPT. OF OCEANOGRAPHY

UNIVERSITY OF WASHINGTON

SEATTLE, WASH. 98105

CONDU

$$
\begin{aligned}
\text { LANGUAGE - FORTRAN IV } \\
\text { COMPUTER - IBM 7094-II/ } \\
7040 \text { DCS }
\end{aligned}
$$

( COPY ON FILE AT NODC)

CALCULATES THERMAL CONDUCTIVITY OF MARINE SEDIMENTS FROM DATA OBTAINED WITH A TRANSIENT TYPE NEEDLE PROBE (ALPINE MODEL 328). TEMPERATUREMILLIVOLT CALIBRATION TABLES ARE INPUT AS DATA. WITH LINEAR INTERPOLATION EMPLOYED IN THE TABLE LOOK-UP SUBROUTINE. ADJACENT PAIRS OF TIME AND TEMPERATURE VALUES ARE USED TO CALCULATE CONDUCTIVITY VALUES. VALUES LYING OUTSIDE OF TWO STANDARD DEVIATIONS ARE REJECTED. OUTPUT IS 
LISTING AND PLOTS. THE BEST CONDUCTIVITY VALUE IS COMPUTED AND PRINTED. AUTHOR-- WILLIAM ANIKOUCHINE, JOINT OCEANOGRAPHIC RESEARCH GROUP (JORG, ESSA), UNIV. OF WASHINGTON. A COPY OF THIS PROGRAM IS ALSO ON FILE WITH THE PACIFIC OCEANOGRAPHIC LABORATORY, 1801 FAIRVIEW AVE.

EAST, SEATTLE, WASH., MR. THEODORE V. RYAN, DIRECTOR.

RADM. HAROLD J. SEABORG

DIRECTOR, PACIFIC MARINE CENTER

COAST AND GEODETIC SURVEY, USESSA

1801 FAIRVIEW AVENUE, EAST

SEATTLE, WASH. 98102

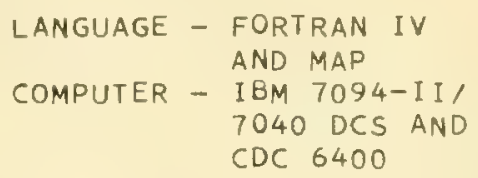

(COPY ON FILE AT NODC)

THE OUTPUT LISTS INPUT DATA, COMPUTED FRACTION PERCENTAGES, ACCUMULATED PERCENTAGES, WEIGHT PERCENTAGES OF GRAVEL, SAND, SILT, AND CIAY, SAND/MUD RATIO, SHEPARD CLASS, TETRAHEDRAL GROUP, PHI-SIZES AT CERTAIN PERCENTILES, TRASK, INMAN, FOLK AND WARD VALUES, AND MOMENTS MEASURES WITH AND WITHOUT SHEPARDIS CORRECTIONS. REF. A REPORT (UWMS-1003, AUG 1966 ) BY THE DEPT. OF OCEANOGRAPHY, APPLIED MATHEMATICS SECTION. CORE STORAGE NECESSARY-- 5327 WORDS. SOURCE DECK HAS 775 CARDS. REVISED 1969 FOR THE CDC-6400.

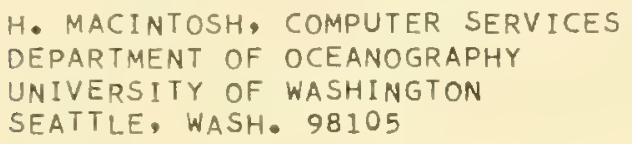

LANGUAGE - FORTRAN COMPUTER - (NOT GIVEN)

( COPY ON FILE AT NODC)

A COMPREHENSIVE PROGRAM, DESIGNED FOR SMALL COMPUTERS, FOR THE TEXTURAL ANALYSIS OF GROUPED SEDIMENT DATA, INCLUDING SIEVED AND PIPETTED SAMPLES. THE PROGRAM CONVERTS THE RAW WEIGHTS OF SIZE-GRADED SEDIMENT INTO WEIGHT PERCENTS, CUMULATIVE PERCENTS, AND A FREQUENCY HISTOGRAM. COMPUTED STATISTICS INCLUDE-- PERCENTS OF GRAVEL, SAND, SILT, AND CLAY FOR LITHOFACIES ANALYSIS, AND MEAN, STANDARD DEVIATION, SKEWNESS, AND KURTOSIS, COMPUTED BY THE METHODS OF MOMENTS, TRASK, INMAN, AND FOLK AND WARD. REF. A REPORT (UNPUBLISHED) JULY 169, 27 P, BY SAM UPCHURCH.

DIRECTOR

GREAT LAKES RESEARCH CENTER

DEPT. OF THE ARMY, CORPS OF ENGINEERS

LAKE SURVEY DISTRICT

DETROIT, MICHIGAN 48226 
LANGUAGE - FORTRAN

COMPUTER - IBM 7074 AND CALCOMP 564

( COPY ON FILE AT NODC)

DISPLAYS GEOLOGICAL SAMPLING INVENTORY DATA AND LOCATION ON CALCOMP PLOTS, GIVEN THE MARSDEN SQUARE OR ADJACENT RECTANGULAR ARRAY OF MARSDEN SQUARES. INPUT IS THE NODC GEOSORTED FILE OF GEOLOGICAI_ DATA. AUTHOR-- ROBERT VAN WIE.

COMPUTER SYSTEMS DIVISION, CODE 2400

NATIONAL OCEANOGRAPHIC DATA CENTER

WASHINGTON, D.C. 20390

BOTTOM SEDIMENT DISTRIBUTION PLOT

( COPY ON FILE AT NODC)

PLOTS BOTTOM SEDIMENT NOTATIONS ON A MERCATOR PROJECTION OF ANY NUMBER OF DEGREES OF LATITUDE ANO LONGITUDE AND TO A SPECIFIED SCALE. CALCOMP SUBROUTINES ARE USED, ALSO A COUNT SUBROUTINE DESIGNED BY MR. WALTER YERGEN OF THIS DIVISION. REF. IMR NO. O-10-66, MAY 1966 (UNPUBI.ISHED MANUSCRIPT), BY R.J. VAN WYCKHOUSE, WHICH LISTS AN EARLIER PRUGRAM FOR PRIMARY GRAIN SIZE, AND AN INFORMAL REPORT IR NO. 68-49, JULY 1968, BY FREDERICK MAAS. DDC USERS MAY OBTAIN COPIES OF THE LATTER REPORT DIRECTLY FROM DDC, OR THROUGH THE COMMANDER, NAVAL OCEANOGRAPHIC OFFICE, ATTN. CODE 40 .

OCEANOGRAPHIC ANALYSIS, GEOLOGY SEC. NAVAL OCEANOGRAPHIC OFFICE SUITLAND, MD. 20390

BIOP (BIOLOGY PLOT)

DOES POSITION (LATITUDE, LONGITUDE) PLOTTING OF BIOLOGICAL SPECIES ON THE CALIFORNIA OFFSHORE IN MERCATOR PROJECTION. AUTHORS-- MR M MANLEY, L. W. YOUNG.

MAR INE LIFE RESEARCH GROUP

SCRIPPS INSTITUTION OF OCEANOGRAPHY

P.O. BOX 109

LA JOLLA, CALIFORNIA 92037

MATHEMATICAL SIMULATION OF MARINE SEDIMENTATION

\author{
LANGUAGE - FORTRAN IV \\ COMPUTER - CDC 3600 , \\ CDC $160 \mathrm{~A}$
}


ANALYZES REGIONAL TRENDS IN DIRECTIONAL DATA. ORTHOGONAL POLYNOMIAL RESPONSE SURFACES ARE COMPUTED AND PLOTTED AS ISOAZIMUTH AND VECTOR TREND MAPS TO AID IN INTERPRETING REGIONAL FLOW PATTERNS. EXAMPLES ARE GIVEN OF THE STUDY OF THE DISTRIBUTION OF CURRENTS WHICH EXISTED NHEN A SEDIMENT WAS DEPOSITED. REF. COMPUTER CONTRIBUTION II, BY WILLIAM T. FOX $(1967)$.

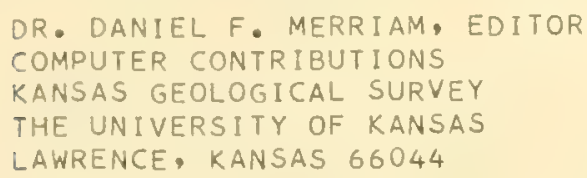

SIMULATION OF DELTAIC SEDIMENTATION

\author{
LANGUAGE - FORTRAN IV-H \\ COMPUTER - IBM 360/67, \\ CALCOMP
}

A SEDIMENT-LADEN RIVER FLOWING INTO A TIDELESS, CURRENTLESS MARINE BASIN IS MODELED AS A PLANE JET DISCHARGING HORIZONTALLY AT THE OCEAN SURFACE. A VELOCITY FIELD IS CALCULATED USING EQUATIONS FOR UPENCHANNEL AND PLANE JET FLOW. SEDIMENT BEHAVIOR IS TREATED STATISTICALLY. NOMINAL SEDIMENT PARTICLES ARE TRACED ALONG TRAJECTORIES FROM THE MOUTH AS THEY SPREAD LATERALLY AND SETTLE VERTICALLY. A DYNAMIC MODEL PERMITS A DELTA TO BUILD FORWARD DURING SEVERAL TIME INCREMENTS, NOMINAL PARTICLE TRAJECTORIES ADJUSTING AUTOMATICALLY TO THE POSITION OF THE DELTA LIP. AUTHORS-- G.F. BONHAM-CARTER AND A.J. SUTHERLAND. COMPUTER CONTRIBUTION 24 (APR 1968).

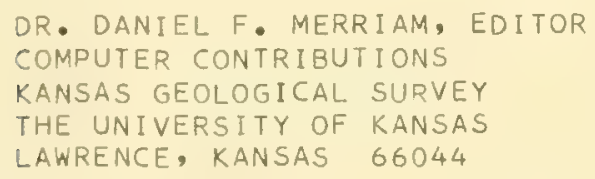

AUTOMATIC CONTOURING

(ABSTRACT NOT RECEIVED.) COMPUTER CONTRIBUTION 23 'COMPUTER PROGRAMS FOR AUTOMATIC CONTOURING', BY D.B. MC INTYRE, D.D. POLLARD, AND R. SMITH, (1968).

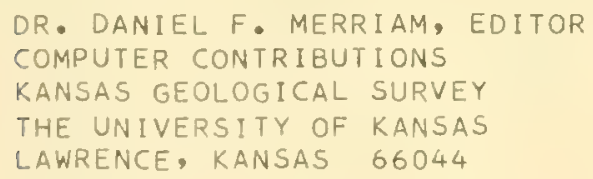

(COPY ON FILE AT NODC)

COMPUTER - (NOT GIVEN)

THREE PROGRAMS WHICH ENABLE THE USER TO GRAPHICALLY PRODUCE A CONTOUR MAP BY THE COMPUTER-PLOTTER METHOD. THE GRIDIT PROGRAM PRODUCES A DIGITIZED MATRIX FROM DATA POINTS WHICH HAVE BEEN SCREENED FOR GROSS ERRORS. REGRIDIT PRODUCES A DIGITIZED MATRIX FROM RAW UNCHECKED DATA POINTS. AUTOMATED CONTOUR CONSTRUCTS A CONTOUR CHART FROM A DIGITIZED MATRIX. AN EXAMPLE IS GIVEN FOR USE OF THE PROGRAM IN CONTOURING THE BATHYMEIRY OF OCEAN BOTTOM. REF. IM NO. 67-4 (INFORMAL MANUSCRIPT) I AN AUTOMATED PROCEDURE FOR PROOUCING CONTOUR CHARTSI, BY ROGER T. OSBORN, FEB. 1967. 
FAA PLOT

( COPY ON FILE AT NODC)

ACCEPTS THREE CARD IMAGES AND A SUPPLIED SET OF FAA DATA CARDS AS INPUT. THE OUTPUT IS A MAGNETIC TAPE TO DRIVE THE E-51, E-103, OR THE E-108 CONCORD DIGITAL PLOTTERS USING THE ECHELON MODE. THE END PRODUCT IS A FILM POSITIVE WITH A PLUS SYMBOL FOR THE POSITION OF THE FAA PLOTS. THE MERCATOR, TRANSVERSE MERCATOR, AND LAMBERT CONIC CONFORMAL PROJECTION WITH TWO STANDARD PARALLELS ARE THE THREE PROJECTIONS WHICH CAN BE USED TO PLOT PROGRAM OUTPUTS. O.S. NO. 65652. AUTHORS-- RONALD M. BOLTON AND J. PARRINELLO.

NAUTICAL CHART OIVISION, CODE 5620

NAVAL OCEANOGRAPHIC OFFICE

SUITLAND, MD. 20390

SOUNDING PLOT

\author{
LANGUAGE - FORTRAN \\ COMPUTER - CDC 3100 AND \\ I BM 7074
}

ACCEPTS LORAC, LORAN, OR RAYDIST LANE VALUES. SHIPS TRACK AND SOUNDINGS ARE PLOTTED ON THE CALCOMP. PRIMARY VERSION IS FOR THE CDC-31OO COMPUTER. AN OBJECT DECK FOR IBM 7074 WILL BE PRODUCED. PLOTTING IS DONE IN UTM MODE. OS NO. 58419. AUTHOR- G.R. BILLS.

GEODESY DIVISION, CODE 8420

NAVAL OCEANOGRAPHIC OFFICE

SUITLAND, MD. 20390

THREE-DIMENSIONAL SURFACE PLOTS

LANGUAGE - FORTRAN

COMPUTER - CDC 3800

SUBROUTINE 'SURFACE' ALLOWS THREE-DIMENSIONAL PLOTS TO BE GENERATED ON THE 565 CALCOMP PLOTTER. THIS SUBROUTINE WILL PRODUCE A SURFACE PLOT OF DATA THAT CAN BE REDUCED TO ONE SINGLE-VALUED DEPENDENT AND TWO INDEPENDENT VARIABLES. NRL MEMO. REPORT 2015. AUTHOR-- J. MOORE.

JOHN C. MOORE

RADAR TECHNIQUES

RADAR DIVISION

NAVAL RESEARCH LABORATORY, WASHINGTON, D. C. 20390

LINE PRINTER PLOTS

$\begin{aligned} & \text { LANGUAGE - } \text { FORTRAN, } \\ & \text { COMPASS } \\ & \text { COMPUTER - CDC } 3800\end{aligned}$

A SUBROUTINE PACKAGE WRITTEN AT THE UNIVERSITY OF WISCONSIN TO PRODUCE LINE PRINTER PLOTS HAS BEEN MODIFIED TO RUN ON NRL'S CDC 3800 . NRL MEMO. REPORT 2046. AUTHOR-- D. DENTON.

DIANNA L. DENTON

RESEARCH COMPUTATION CENTER

MATHEMATICS AND INFORMATION SCIENCES DIVISION

NAVAL RESEARCH LABORATORY, WASHINGTON, D. C. 20390

PLOT THETA-S CURVES

$$
\begin{aligned}
\text { LANGUAGE - } & \text { FORTRAN I I } \\
\text { COMPUTER - } & \text { CDC } 3100 / \\
& \text { PDP-8 AND } \\
& \text { CALCOMP }
\end{aligned}
$$

PLOTS POTENTIAL TEMPERATURE VS. SALINITY. CARD INPUT, OUTPUT PRINTED LISTING AND PUNCHED PAPER TAPE. STATION PLOT USES A PDP- 8 COMPUTER, 
PAPER TAPE READER, AND CALCOMP. AUTHOR- R. REINIGER.

DIRECTOR

ATLANTIC OCEANOGRAPHIC LABORATORY

BEDFORD INSTITUTE

DARMOUTH, NOVA SCOTIA, CANADA

PLOT STATION POSITIONS

$$
\begin{aligned}
\text { LANGUAGE - } & \text { FORTRAN II } \\
\text { COMPUTER - } & \text { CDC } 3100 / \\
& \text { PDP-8 AND } \\
& \text { CALCOMP }
\end{aligned}
$$

PLOTS CRUISE STATION POSITIONS ON :IERCATOR'S PROJECTION AND WRITES IN STATION NUMBER. 'PLOTL' PLOTTING ROUTINE USED WITH PDP-8 COMPUTER AND THE CALCOMP. AUTHOR-- R. REINIGER (SEPT 1968).

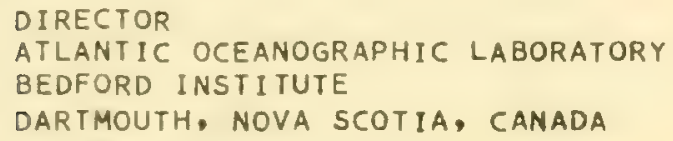

(COPY ON FILE AT NODC)

THE PROGRAM USES THE CDC 3100 PLOTTING SUBROUTINES TO GENERATE DATA

FOR THE PDP-8 PLOTTING PROGRAM. THE USER MAY SPECIFY A LEGEND IUP TO

480 (HARACTERS), LABEL SIZES, SCALE FACTORS, THE PARAMETER TO BE PLOTTED AND THE ISOPLETHS TO BE DETERMINED. THE PLOTTING IS DONE ON A CALCOMP 31 IN. PLOTTER UNDER CONTROL OF THE PDP-8. CRUISE DATA IS READ FROM MAGNETIC TAPE BY THE CDC 3100 IN MODIFIED CODC FORMAT OR BI FORMAT• STORAGE REQUIREMENTS-- $11000(8)$ IN THE CDC 3100 (INCLUDING PLOTTING SUB-PROGRAMSI. AN ITERATIVE METHOD IS USED IN CONJUACTION WITH AN INTERPOLATION FUNCTION TO DETERMINE ISOPLETH DEPTHS. THE INTERPOLATION FUNCTION IS DESCRIBED IN A BEDFORD INSTITUTE REPORT, BIO 66-3 (FEB 1966, UNPUBLISHED MANUSCRIPT) BY R.F. REINIGER AND C.K. ROSS

DIRECTOR

ATLANTIC OCEANOGRAPHIC LABORATORY BEDFORD INSTITUTE

DARTMOUTH, NOVA SCOTIA, CANADA

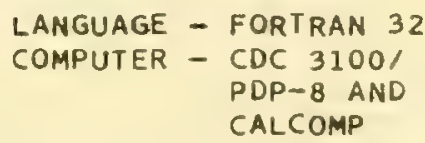

I COPY ON FILE AT NODCI

THE PROGRAM USES THE CDC 3100 PLOTTING SUBROUTINES TO GENERATE DATA

FOR THE PDP-8 PLOTTING PROGRAM. THE USER MAY SPECIFY A LEGEND IUP TO

480 CHARACTERS). LABEL SIZES, SCALE FACTORS, THE PARAMETER TO BE PLOTTED AND THE ISOPLETHS TO BE DETERMINED. THE PLOTTING IS DONE ON A CALCOMP 31 IN. PLOTTER UNDER CONTROL OF THE PDP-8. CRUISE DATA IS READ FROM MAGNETIC TAPE BY THE CDC 3100 IN BI FORHAT. TIME IS PLOTTED ALONG THE $X$ AXIS (DRUM MOVEMENT) AND DEPTH ALONG THE $Z$ AXIS (PEN MOVEMENT). STATIONS ARE PLOTTED TO THE NEAREST DAY. AUTHOR-- D.J. LAWRENCE $(06 / 06 / 69)$.

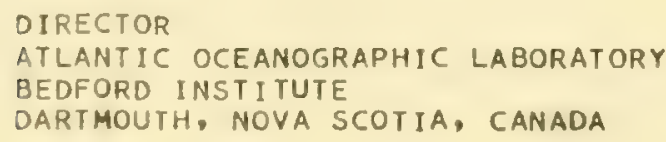


(COPY ON FILE AT NODC)

PLOTS THE RESULTS OF HYDROGRAPHIC CASTS IN A FORMAT SUITABLE FOR PUB-

LICATION. PRODUCES $81 / 2$ BY 10 IN. PLOTS OF LOGIIOIOEPTH VS. TEMPERATURE, SALINITY, AND OXYGEN.

DR. C. A. COLLINS

MARINE SCIENCES BRANCH, DEMR

PACIFIC OCEANOGRAPHIC GROUP

BIOLOGICAL STATION

NANAIMO, B.C., CANADA

STPO1

$$
\begin{aligned}
\text { LANGUAGE - } & \text { FORTRAN IV } \\
\text { COMPUTER - } & \text { IBM } 1130 / \text { IBM } \\
& 1627 \text { PLOTTER }
\end{aligned}
$$

(COPY ON FILE AT NODC)

PLOTS DIGITIZED S.T.D. DATA IN A FORMAT SUITABLE FOR PUBLICATION. THE PLOTTER DRAMS AND LABELS AXES AND PLOTS TEMPERATURE AND SALINITY VS. DEPTH.

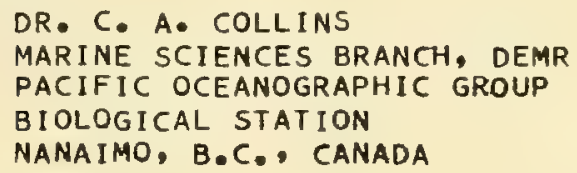

PSALI (PLOT TEMPERATURE-SALINITY)

LANGUAGE - FORTRAN VI COMPUTER - IBM 1130

(COPY ON FILE AT NODC)

PLOTS T-S AND EXPANDED T-S CURVES. INPUT-- HYDROGRAPHIC DATA IM CODC FORMAT. ANOTHER PROGRAM, PSAL3, PLOTS OXYGEN-SALINITY AND TEMPERATURE-OXYGEN CURVES. REF. FRB MS. REPORT NO. 1071 (DEC 1969), BY C.A. COLLINS, R.L.K. TRIPE AND S.K. WONG.

PACIFIC OCEANOGRAPHIC GROUP

BIOLOGICAL STATION

NANAIMO, B. C., CANADA

GENERAL PURPOSE PLOT AND 'SPECTDPLOT'

$$
\begin{aligned}
\text { LANGUAGE - } & \text { FORTRAN } \\
\text { COMPUTER - } & \text { IBM } 7074 \text { W/ } \\
& \text { CALCOMP }
\end{aligned}
$$

( COPY ON FILE AT NODC)

TWO PROGRAMS WITH CONSIDERABLE GENERALITY WHICH ALLOW THE USER TO DEFINE HIS ORIGIN, SCALE FACTORS, GRID ANNOTATION ANO DATA SET, OR AMY NUMBER OF DATA SETS. AN ADDED PROVISION ALLOWS DATA RECORDED IN THE FIELD (I.E. ABOARD RESEARCH SHIPS), TO BE PROCESSED DIRECTLY FROM THE FIELD TAPES WITH A MINIMUM OF PREPARATORY PROCESSING. EITHER THE ROTARY-TYPE OR FLAT-BED PLOTTER MAY BE USED. OS NOS. 20255 AND $20264^{\circ}$ INFORMAL REPORT REF. NO. IR 69-65 (AUG 1969, 7OP). AUTHOR-- ERNEST L. MABREY. FURTHER INFORMATION MAY BE OBTAINED FROM THE DISSEMINATION DEPT. (CODE 44), OR THE AUTHOR.

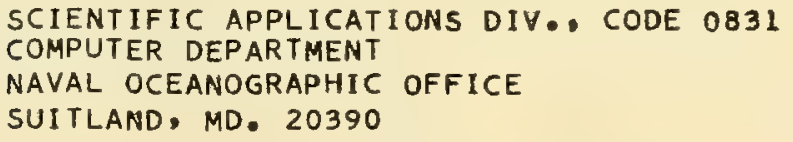


PLOTS DATA VALUES AGAINST DEPTH OR OTHER PARAMETERS.

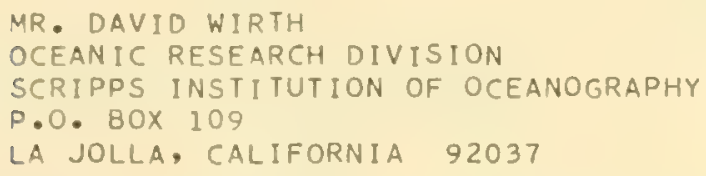

THE VORTEX OCEAN MODEL

$$
\begin{aligned}
& \text { LANGUAGE - DECAL } \\
& \text { COMPUTER - PDP-7(9) }
\end{aligned}
$$

SIMULATES A VORTEX OCEAN MODEL AND DISPLAYS RESULTS ON COMPUTER SCOPE. COLLECTS STATISTICS ON THE MODEL. RESEARCHER CAN CONTROL THE CONFIGURATION OF THE SIMULATION, MAY AT ANY TIME DURING COMPUTATION EXAMINE OR CHANGE THE VALUE OF ANY VARIABLE. IN THE MODEL, A SET OF VORTICES INTERACT IN A CIRCULAR OR UNBOUNDED OCEAN. NUMBER OF VORTICES CAN BE VARIED FROM I TO 31. ALSO, A SPECIAL TEST POINT USED TO COLLECT STATISTICS ON THE EFFECTS OF THE VORTICES. EACH VORTEX ROTATES WITH A STRENGTH, WHERE THE (I)TH VORTEX ROTATES WITH STRENGTH S(I). THE ROTATION OF EACH VORTEX AFFECTS THE POSITION OF ALL OTHERS. OPERATION IS SUFFICIENTLY FAST TO SHOW SEVERAL VORTICES IN OPERATION, FLICKERFREE. PROGRAM IS CONTROLLED FROM AN ON-LINE TYPEWRITER VIA CONTROL CHARACTERS. PROGRAM WRITEUP IS AVAILABLE ON REQUEST.

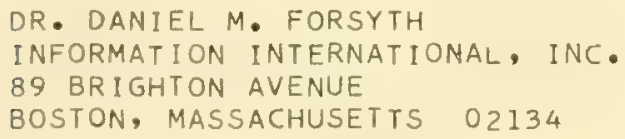

THE WODD SYSTEM ENABLES A RESEARCHER TO CONDUCT AN ANALYSIS OF OCEANOGRAPHIC DATA USING A SERIES OF VISUAL DISPLAYS GENERATED BY A DIGITAL COMPUTER. THE EVENTUAL GOAL OF THE SYSTEM WILL BE TO HOLD AND MAKE AVAILABLE FOR DISPLAY THE ENTIRE BODY OF WORLD OCEANOGRAPHIC DATA. THE RESEARCHER WILL BE ABLE TO SELECT SPECIFIC DATA FOR DISPLAY, IN THE FORM OF CONTOUR LINES AGAINST A MAP OF SELECTED OCEANIC DATA. HE WILL BE ABLE TO VARY THE PARAMETERS OF THE DATA SELECTED AND OBSERVE THE RESULTING VARIATIONS IN THE CONTOUR LINES. AT ITS PRESENT STAGE OF DEVELOPMENT, THE SYSTEM CONSISTS OF A PDP-7 COMPUTER, A CATHODE RAY TUBE VISUAL DISPLAY UNIT, A MAGNETIC TAPE UNIT, A LIGHT PEN, INPUTOUTPUT TYPEWRITER. BROCHURE DESCRIBING SYSTEM IS AVAILABLE ON REQUEST

DR. DANIEL M. FORSYTH

INFORMATION INTERNATIONAL, INC.

89 BRIGHTON AVENUE

BOSTON, MASSACHUSETTS 02134 
(COPY ON FILE AT NODC)

UTILIZES MERIDIONAL PARTS TO LOCATE DATA POINTS ON MERCATOR-PROJECTION MAPS. FORTRAN PROGRAM USES A SHARED-TIME PLOTTING ROUTINE. THE CON-

TINENT OUTLINES CAN ALSO BE PLOTTED BY STRAIGHT-LINE SEGMENTS. REF.NUWC TP 89 (DEC 1968,44 P.). AUTHOR-- L.A. SMOTHERS. PROGRAMMER-K.K. STARR.

OCEAN SCIENCES DEPARTMENT

NAVAL UNDERSEA RESEARCH AND DEVELOPMENT CENTER

SAN DIEGO, CALIFORNIA 92132

VACOTS IVERTICALLY ANALYZED CONTOURS OF OCEANOGRAPHIC TEMPERATURES AND SALINITIES)

(COPY ON FILE AT NODC)

PROVIDES A RAPID AND ACCURATE MEANS OF CONSTRUCTING VERTICAL CROSSSECTIONS OF SEA TEMPERATURES AND SALINITIES. ALTHOUGH THIS PROGRAM HAS BEEN DESIGNED TO USE S.T.D. DATA RECORDED ON MAGNETIC TAPE, OTHER VERSIONS ALSO ARE BEING USED TO CONTOUR BIOLOGICAL, CHEMICAL AND OTHER PHYSICAL OCEANOGRAPHIC DATA. EACH VERTICAL SECTION IS DIVIDED INTO TWO PARTS - THE UPPER SECTION FOR THE CONTOURS FROM SURFACE TO 300 M. AND THE LOWER SECTION FROM $300 \mathrm{M}$. TO $1000^{\circ} \mathrm{M}$. CORE MEMORY SIZE NEEDED - 32,000 WORDS. RUNNING TIME-- TO ANALYZE AND PLOT CONTOURS AT INTERVALS OF 1 DEGREE C. FOR TEMPERATURE AND 1 0/00 FOR SALINITY FROM THE SURFACE TO $1000 \mathrm{M}$. FOR 50 STATIONS REQUIRES 4 MINUTES OF COMPUTER TIME ON THE CDC 3600 AND 25 MINUTES ON THE CALCOMP 30 IN. PLOTTER. AUTHOR

- FORREST MILLER.

BUREAU OF COMMERCIAL FISHERIES

P.O. BOX 271

LA JOLLA, CALIFORNIA 92038
LANGUAGE - FORTRAN

COMPUTER - CDC $3100 /$ CALCOMP 750

(COPY ON FILE AT NODC)

PROVIDES FOR THE PRODUCTION OF TEMPERATURE-SALINITY DIAGRAMS FROM

SERIAL OCEANOGRAPHIC OBSERVATIONS. INPUT IS DATA CARDS AND A PLOT CONTROL CARD. OUTPUT IS PLOTTER TAPE AND A PRINTED SUMMARY OF OUT-OFRANGE DATA. REF. MS REPORT NO. 6 (1967). AUTHOR-- J.R. WILSUN.

OCEANOGRAPHIC RESEARCH DIVISION

MARINE SCIENCES BRANCH

DEPT. OF ENERGY, MINES AND RESOURCES

OTTAWA, CANADA

( COPY ON FILE AT NODC)

PLOTS TEMPERATURE VS. SALINITY CURVES ON 12 IN. PLOTTER, EITHER SINGLE OR MULTIPLE STATIONS. INPUT IS ICES FORMAT HYDROGRAPHIC DATA . CORE STORAGE USED-- $31 \mathrm{~K}$ BYTES (INCLUDES PLOT ROUTINES). AUTHOR-- MARILYNN BORKOWSKI.

BUREAU OF COMMERCIAL FISHER IES

TROPICAL ATLANTIC BIOLOGICAL LABORATORY

75 VIRGINIA BEACH DRIVE

MIAMI, FLORIDA 33149 
(COPY ON FILE AT NODC)

PLOTS OXYGEN VS. PHOSPHATE, OXYGEN VS. SIGMA-T, AND PHOSPHATE VS. SIGMA-T (SINGLE OR MULTIPLE STATION) FOR PURPOSES OF QUALITY CONTROL AND STUDY OF WATER TYPES. INPUT IS HYDROGRAPHIC DATA IN ICES FORMAT. CORE STORAGE USED - $33 K$ BYTES INCLUDING PLOT ROUTINES. AUTHOR-- MARILYNN BORKOWSKI.

BUREAU OF COMMERCIAL FISHERIES

TROPICAL ATLANTIC BIOLOGICAL LABORATORY 75 VIRGINIA BEACH DRIVE

MIAMI, FLORIDA 33149

MERCATOR STATION PLOT

$$
\begin{aligned}
\text { LANGUAGE - } & \text { FORTRAN IV } \\
\text { COMPUTER - } & \text { IBM } 360 / 65, \\
& \text { CALCOMP }
\end{aligned}
$$

WRITES STATION NUMBERS AT THEIR POSITIONS ON A MERCATOR PROJECTION IN ANY SCALE/DEGREE. INPUT-- STATION HEADER CARDS IN ICES FORMAT. AUTHOR-- MARILYNN BORKOWSKI.

BUREAU OF COMMERCIAL FISHERIES

TROPICAL ATLANTIC BIOLOGICAL LABORATORY

75 VIRGINIA BEACH DRIVE

MIAMI, FLORIDA 33149

HORIZONTAL SECTIONS

$$
\begin{aligned}
\text { LANGUAGE - } & \text { FORTRAN IV } \\
\text { COMPUTER - IBM } 360 / 65, & \text { CALCOMP }
\end{aligned}
$$

WRITES IN VALUES OF TEMPERATURE, SALINITY, OXYGEN, PHOSPHATE, ON SEPARATE MERCATOR PROJECTIONS, AT SPECIFIED DEPTHS. INPUT-- HYDROGRAPHIC DATA IN ICES FORMAT, AT STANDARD DEPTHS. AUTHOR- - MARILYNN BURKOWSKI.

BUREAU OF COMMERCIAL FISHERIES

TROPICAL ATLANTIC BIOLOGICAL LABORATORY 75 VIRGINIA BEACH DRIVE MIAMI, FLORIDA 33149

GENERAL MERCATOR PLOT

$$
\begin{aligned}
\text { LANGUAGE - } & \text { FORTRAN IV } \\
\text { COMPUTER - } & \text { IBM } 360 / 65, \\
& \text { CALCOMP }
\end{aligned}
$$

PLOTS ANY VARIABLE ON A MERCATOR PROJECTION. HAS OPTION OF WRITING IN VALUE OR MAKING A POINT PLOT, AND OF CONNECTING THE POINTS WITH LINES. INPUT - ANY HEADER CARDS IN ICES FORMAT. PROJECTION PLOT MAY BE IN ANY SCALE PER DEGREE, AND MAY INCLUDE A COASTLINE IOBTAINED FROM A DIGITIZED WORLD TAPE LAYOUT). CORE STORAGE NECESSARY-- 42K BYTES (INCLUDES PLOT ROUTINES). AUTHOR-- MARILYNN BORKOWSKI.

BUREAU OF COMMERCIAL FISHERIES

TROPICAL ATLANTIC BIOLOGICAL LABORATORY

75 VIRGINIA BEACH DRIVE

MIAMI, FLORIDA 33149

ISOS, OXOS, PHOS

$$
\begin{aligned}
& \text { LANGUAGE - } \text { FORTRAN IV } \\
& \text { COMPUTER - IBM } 360 / 65 \\
& \text { WITH CAICOMP }
\end{aligned}
$$

PLOTS ISENTROPIC SECTIONS FOR SALINITY, OXYGEN, OR PHOSPHATE FOR THE STANDARO STATIONS OF THE TRADE WIND ZONE OCEANOGRAPHY PROGRAM. INPUT IS THE TRADE WIND ZONE OCEANOGRAPHY PRUGRAM ISENTROPIC FORMAT CARDS.

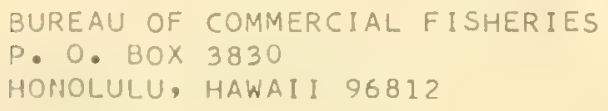


PLOTS TIME HISTORY OF TEMPERATURE, SALINITY, OR OXYGEN FOR STANDARD STATIONS OF THE TRADE WIND ZONE OCEANOGRAPHY PROGRAM PILOT STUDY. INPUT IS TRADE WIND ZONE OCEANOGRAPHY PROGRAM ISENTROPIC FORMAT CARDS.

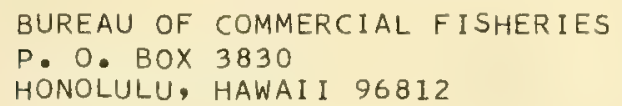

\section{BATHYTHERMOGRAM COMPOSITE PLOT}

LANGUAGE - FORTRAN

COMPUTER - IBM1401/7074

(COPY ON FILE AT NODC)

COMPUTES (1) NUMBER OF OBSERVATIONS AT 50 METER INTERVALS, (2) PERCENTAGE FOR EACH QUALITY CODE, (3) PLOTS PER SEASON AND AREA (AS DETERMINED BY A 1401 PROGRAM) USUALLY TO 35 LINES PER PAGE (NEVER EXCEEDING 44). INPUT-- NODC FORMAT DIGITIZED BT DATA, SORTED BY STATION AND DEPTH. OUTPUT-- TAPE FOR CALCOMP $670 / 564$ PLOTTER. OS NO. 52208 . AUTHOR-- RUDI SAENGER.

COMPUTER SYSTEMS DIVISION

NATIONAL OCEANOGRAPHIC DATA CENTER

WASHINGTON, D.C. 20390

INVENTORY PLOT

$$
\begin{aligned}
& \text { LANGUAGE - } \text { FORTRAN IV } \\
& \text { COMPUTER - IBM } 360 / 40 \\
& \text { CALCOMP } 763
\end{aligned}
$$

DISPLAYS AN INVENTORY OF STATION DATA PARAMETERS, BT DATA, GEOLOGICAL SAMPLES, ETC. (ANY GEOGRAPHICALLY SORTED DATA FILE), BY 1-DEGREE, 2DEGREE, AND 5-DEGREE SQUARES, AND ON ANY OF EIGHT MAP PROJECTIONS OF SPHERE. OUTPUT-- A TAPE FOR THE CALCOMP $780 / 763$ DRUM PLOTTER. AUTHOR-- JOHN WARD. WILL USE A STATION DATA PARAMETER INVENTORY PROGRAM NOW BEING WRITTEN IN ASSEMBLER LANGUAGE BY JEFF GORDON, AND OTHER PROJECTED PROGRAMS.

COMPUTER SYSTEMS DIVISION

NATIONAL OCEANOGRAPHIC DATA CENTER

WASHINGTON, D. C. 20390

\section{CRUISE TRACK - MERCATOR PROJECTION}

$$
\begin{aligned}
& \text { LANGUAGE - FORTRAN } \\
& \text { COMPUTER - IBM } 7074
\end{aligned}
$$

( COPY ON FILE AT NODC)

INPUT-- NASA DIGITIZED WORLD LAYOUT TAPE, AND NODC FORMAT STATION DATA (UP TO 600 STATIONS IN A CRUISE). PROCEDURE- DETERMINE MAXIMUM AND MINIMUM LATITUDE, AND ROUND TO NEAREST FIVE DEGREES, THEN DETERMINE SCALE FACTOR, LONGER SIDE EQUAL TO 20 INCHES. OUTPUT-- TAPE FOR CALCOMP $670 / 564$ PLOTTER. OS NO. 52210. AUTHOR-- RUDI SAENGER. NOTE-THIS WILL SOON BE REPLACED AT NODC BY A NEW MULTI-PROJECTION PROGRAM FOR CRUISE TRACKS, WRITTEN IN FORTRAN BY JOHN WARD FOR THE IBM 360.

COMPUTER SYSTEMS DIVISION

NATIONAL OCEANOGRAPHIC DATA CENTER

WASHINGTON, D. C. 20390

VERTICAL SUMMARY HISTOGRAM PLOT

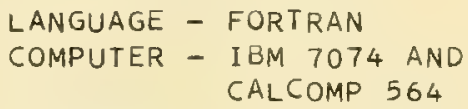

( COPY ON FILE AT NODC)

PLOTS PERCENT-FREQUENCY HISTOGRAMS AT EACH OF A MAXIMUM OF 20 STANDARD DEPTHS, EACH PLDT FOR A GIVEN 1-DEGREE SQUARE AND MONTH. INPUT DATA ARE PREPARED BY THE STATION DATA VERTICAL ARRAY SUMMARY PROGRAM. NO. 52235. AUTHOR-- ROBERT VAN WIE. 
TAL PHOSPHORUS, NITROGEN, SILICON, OR COPPER.

(2) PLOTS VERTICAL SECTIONS WITH NUMERICAL INSTEAD OF CONTOUR LINES

FOR PARAMETERS INORGANIC PHOSPHORUS, TOTAL PHOSPHORUS, NITROGLN, SILI-

CON, OR COPPER. INPUT-- OBSERVED NODC FORMAT STATION DATA TAPE ZONE-

EDITED TO 120 CHARACTERS PER RECORD, SORTED BY CRUISE REFERENCE NO.

OUTPUT-- INPUT TAPE TO CALCOMP PLOTTER 670/564. RUNNING TIME-- ABOUT

70 SECTIONS PER HOUR. OS NO. 52279. AUTHOR-- ROBERT VAN WIE, MODIFYING AND CONTINUING OS NOS. 52278 AND 52279 BY DANIEL ROBERTS.

COMPUTER SYSTEMS DIVISION

NATIONAL OCEANOGRAPHIC DATA CENTER

WASHINGTON, D. C. 20390

\author{
OCEANOGRAPHIC DATA PLOTTING PROGRAM FOR \\ N.O.D.C. DATA
}

$$
\begin{aligned}
\text { LANGUAGE - } & \text { FORTRAN I I } \\
\text { COMPUTER - } & \text { IBM } 1620 \text { FOR } \\
& \text { CALCOMP } 560
\end{aligned}
$$

(COPY ON FILE AT NODC)

THE INPUT DATA CARDS ARE RECEIVED FROM THE NATIONAL OCEANOGRAPHIC DATA CENTER. THE PROGRAM IS DESIGNED TO PLOT OCEANOGRAPHIC STATION DATA DOWN TO A DEPTH OF 10,000 METERS. THIS IS DONE ON A SERIES OF UP TO 5 GRAPHS, EACH OF WHICH HAS A RANGE OF 2,000 METERS. THIS IS A COMPOSITE GRAPH CONSISTING OF TEMPERATURE, SIGMA-T, SOUND VELOCITY, SALINITY, OXYGEN AND PHOSPHATE. THE SALINITY, PHOSPHATE AND OXYGEN VALUES ARE PLOTTED VS TEMPERATURE. DENSITY, SOUND VELOCITY AND TEMPERATURE ARE PLOTTED AGAINST DEPTH. ALL TEMPERATURE DEPENDENT VARIABI_ES ARE PLOTTED ON THE FIRST GRAPH. THE CONTINUING GRAPHS CONTAIN ONI-Y DEPTH DEPENDENT VARIABLES. THE GRAPH IS FULLY IDENTIFIED AS TO REFERENCE NUMBER, STATION LOCATION AND DATE, ETC. EACH CURVE IS IDENTIFIED BY ITS PLOTTING SYMBOL. AUTHORS-- D.L. SHAFFER AND D.T. EGER.

\author{
UNIVERSITY OF MIAMI \\ MARINE LABORATORY \\ COMPUTER CENTER \\ 1 RICKENBACKER CAUSEWAY \\ VIRGINIA KEY, MIAMI, FLORIDA
}
OCEANOGRAPHIC DATA PLOTTING PROGRAM, I.C.E.S. LANGUAGE - FORTRAN II
COMPUTER - IBM 1620 FOR CALCOMP 560

(COPY ON FILE AT NODC)

THE INPUT TO THIS PROGRAM CONSISTS OF THE OUTPUT OF THE IN SITU OCEANOGRAPHIC DATA PROCESSING PROGRAM. HOWEVER, THIS PROGRAM REQUIRES THAT HEADER CARDS BE INCLUDED. SINCE THE PROGRAM ESSENTIALLY INTEGRATES ONE STATION AT A TIME AND THEN PLOTS IT, THE HEADER CARDS SERVE TO INDICATE THE BEGINNING OF A NEW STATION. AUTHOR-- D.L. SHAFFER.

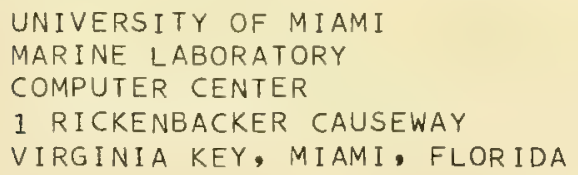

PRODUCES HORIZONTAL BAR HISTOGRAMS OF ANY VARIABLE THAT IS STORED ON MAGNETIC TAPE IN STANDARD WHOI FORMAT. OUTPUT IS A BAR HISTOGRAM DRAWN BY THE LINE PRINTER. THE WHOI GENERALIZED TAPE FORMAT IS PRESENTED IN A TECHNICAL REPORT IA NINE CHANNEL DIGITAL MAGNETIC TAPE FOR STORING OCEANOGRAPHIC DATA', REF. NO. 69-55, JULY 1969, BY JOHN A. MALTAIS.

INFORMATION PROCESSING CENTER

ATTN. JOHN A. MALTAIS

WOODS HOLE OCEANOGRAPHIC INSTITUTION

WOODS HOLE, MASSACHUSETTS 02543 
LISTS AND PLOTS THE DATA STORED ON WHOI FORMAT MAGNETIC TAPE. OUTPUT IS ON THE LINE PRINTER. THREE TYPES OF PLOT ARE POSSIBLE - AI VARIABLE VS TIME OR SEQUENCE NUMBER, B) ANGLE AND SPEED VS TIME, CI TWO VARIABLES IONE ON A MINUS AND ONE ON A PLUS SCALE, VS TIME.

INFORMATION PROCESSING CENTER

ATTN. JOHN A. MALTAIS

WOODS HOLE OCEANOGRAPHIC INSTITUTION

WOODS HOLE, MASSACHUSETTS 02543

TSPLOT

LANGUAGE - FORTRAN IV-E

COMPUTER - IBM $360 / 50$

GENERATES A PUNCHED DECK TO BE USED AS INPUT TO THE BENSON-LEHNER

DELTA INCREMENTAL PLOTTER. FOR EACH HYDROGRAPHIC STATION A SEPARATE TEMPERATURE VS. SALINITY GRAPH IS DRAWN. SALINITY RANGE IS 32.60100 TO 37.8 0/00. ON THE SAME PAGE TWO TEMPERATURE $V S$. DEPTH GRAPHS ARE DRAWN, ONE FROM O TO $600 \mathrm{M}$. THE OTHER FROM $200 \mathrm{M}$ TO THE BOTTOM. THESE ARE COMPLETE WITH AXIS, TICK MARKS AND LABELS. SIZE OF GRAPHS IS AN INPUT VARIABLE.

ROBERT K. SEXTON

NARRAGANSETT MARINE LABORATORY

UNIVERSITY OF RHODE ISLAND

KINGSTON, RHOOE ISLAND 02881

SEQUENTIAL PLOTTING

LANGUAGE - FORTRAN

COMPUTER - \{NOT GIVEN\}

(COPY ON FILE AT NODC)

SUBROUTINES PRODUCE PLOTS USING A DIGITAL COMPUTER OUTPUT PRINTER.

THE CONSECUTIVE $X, Y$ DATA POINTS ARE PLOTTED WITH SYMBOLS CONSISTING OF LETTERS AND NUMERALS. PERMITS RAPID PLOTTING OF EITHER A SINGLE- OR MULTIVALUED CURVE WHEN HIGH RESOLUTION IS NOT REQUIRED. REF. NELC REPORT 1613 (MAR 1969,40 P) BY R・G. ROCK. DIRECT INQUIRIES TO--

NAVAL ELECTRONICS LABORATORY CENTER

SAN DIEGO, CALIFORNIA 92152

DATA FIELD GRID EXPANSION

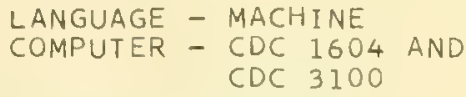

EXPANDS A PORTION OF A $63 \times 63$ GRID DATA FIELD TO ANY DESIRED SCALE. THE EXTRACTED PORTION OF THE BASIC FIELD IS OF ARBITRARILY SELECTED SIZE, SCALE, LOCATION, ORIENTATION, AND CONTOUR INTERVAL. THE METHOD EMPLOYED IS DOUBLE INTERIOR QUADRATIC INTERPOLATION FROM THE ORIGINAL GRID POINTS TO THE LOCATION OF THE ARRAY IN THE NEW FIELD. THE TIME REQUIRED FOR THE EXTRACTION PROCESS IS SIX SECONDS IN THE 1604 AND LESS THAN TWO SECONDS IN THE 3100 COMPUTER - REF. TECHNICAL MEMO NO. 1. ALSO TECHNICAL NOTE NO. 21 (1966)

COMMANDING OFFICER

FLEET NUMERICAL WEATHER CENTRAL

MONTEREY, CALIFORNIA 93940 
LEAST SQUARES CURVE FITTING IN TWO, THREE, AND FOUR DIMENSIONS

(COPY ON FILE AT NODC)

THREE SUBROUTINES, 'UCF', 'BCF', AND 'TCF' IFOR UNIVARIATE, BIVARIATE, AND TRIVARIATE CURVE-FIT), FOR USE IN TWO-, THREE-, AND FOUR-SPACE. CURVE COEFFICIENTS CALCULATED BY REDUCTION TECHNIQUE DUE TO P.D. CROUT (1941). OUTPUT-- PRINTOUT OF COEFFICIENTS, IN NORMALIZED FLOATINGPOINT, AND DIFFERENCES CURVE-TO-POINTS, IN SAME FORMAT. SATELLITE SUBROUTINE 'SYMMET' IS CALLED, WHICH SOLVES M SIMULTANEOUS ALGEBRAIC EQUATIONS IN $X$. CORE STORAGE NECESSARY - $2074(8), 2076(8)$, AND 2256 (8), RESPECTIVELY, + 63018) FOR SUBROUTINE SYMMET. REF. B.I.O. COMPUTER NOTE 68-1-C, JAN 1968. AUTHOR-- F.K. KEYTE.

DIRECTOR

ATLANTIC OCEANOGRAPHIC LABORATORY

BEDFORD INST ITUTE

DARTMOUTH, NOVA SCOTIA, CANADA

A GENERALIZED 2-DIMENSIONAL REGRESSION PROCEDURE

\author{
LANGUAGE - ALGUL AND \\ FORTRAN IV \\ COMPUTER - B5500 AND \\ IBM 7040
}

ENABLES SELECTION OF BEST FIT OF A SET OF OBSERVATIONS WITHOUT REGENERATION OF LOWER ORDER COEFFICIENTS. USES THE MINIMIZATION PROPERTY OF ORTHOGONAL FUNCTIONS. AUTHOR-- JOHN R. DEMPSEY, NORTHERN NATURAL GAS COMPANY. PUBLISHED 1966 AS 'COMPUTER CONTRIBUTION 21 WITH ALGOL LANGUAGE LISTING. A FORTRAN VERSION HAS BEEN RUN ON THE IBM 7040.

DR. DANIEL F. MERRIAM, EDITOR, COMPUTER CONTRIBUTIONS

KANSAS GEOLOGICAL SURVEY

THE UNIVERSITY OF KANSAS

LAWRENCE, KANSAS 66044

GENERAL REGRESSION

LANGUAGE - PL/I

(COPY ON FILE AT NODC)

COMPUTER - IBM OS/360

OBSERVATIONS MAY BE SELECTED BY GROUPS - UP TO 75 GROUPS ARE ALLOWED. THESE SELECTED OBSERVATIONS ARE TO BE USED TO COMPUTE SIMPLE CORRELATIONS BETWEEN ALL PAIRS OF THE SELECTED VARIABLES. SOME OF THE CORRELATION COEFFICIENTS MAY BE FURTHER USED AS NORMAL EQUATION COEFFICIENTS OR CONSTANTS FOR REGRESSION ANALYSES INVOLVING TWO OR MORE OF THESE VARIABLES. IF DESIRED, A DIFFERENT SUBSET OF OBSERVATIONS MAY BE SELECTED TO COMPUTE RESIDUALS, STANDARD ERRORS OF PREDICTED VALUES, ETC. EITHER CARDS OR TAPE MAY CONTAIN MOST OF THE DATA. IF TAPE IS TO BE USED FOR THE OESERVATION MATRIX, IT MUST HAVE BEEN CREATED BY A DIFFERENT PROGRAM AND BE IN A SPECIAL PL/I STREAM I/O FORMAT.

U. S. GEOLOGICAL SURVEY

COMPUTER CENTER DIVISION

ATTN. RALPH EICHER, CHIEF

BRANCH OF SCIENTIFIC APPLICATIONS

WASHINGTON, D. C. 20242 
PROGRAM SYSTEM CONSISTS OF A SET OF NEARLY INDEPENDENT SECTIONS FUNCTIONING ONLY WHEN CALLED BY THE IMAIN, PROGRAM. THE USER ENTERS A CURVE INTO THE $360 / 40$ VIA A RAND TABLET AND INTERACTIVELY TO SPECIFY VARIOUS WAYS OF FITTING, EDITING AND DISPLAYING THE CURVE ON AN IBM 2250 SCOPE. THE LAST STEP OUTPUT IS PUNCH CARDS WITH DATA POINTS. OR COEFFICIENTS. THE SYSTEM FOR IBM 360 ALONG WITH THE PACKAGE OF GRAPHICS USED AT RAND TAKE UP ROUGHLY ONE-HALF OF THE COMPUTER CORE MEMORY. DOCUMENT BY A.S. PRIVER, SEPT 1969. THE DDC NO. IS AD 693920.

THE RAND CORPORATION

1700 MAIN ST.

SANTA MONICA, CALIF. 90406

BARTLETT'S CURVE FITTING

LANGUAGE - FORTRAN

COMPUTER - IBM 1800 SYS

(COPY ON FILE AT NODC)

BARTLETTIS METHOD FOR COMPUTING THE BEST VALUES FOR FITTING A LINEAR

RELATIONSHIP OR AN EXPONENTIAL RELATIONSHIP. THE 70 0/0 AND $900 / 0$

CONFIDENCE LIMITS ON THE SLOPE ARE ALSO FOUND. THE PROGRAM TAKES A

MAXIMUM OF 99 SETS OF DATA EACH WITH A MAXIMUM OF 500 POINTS. N.I.O.

PROGRAM 174. AUTHOR-- MAUREEN TYLER.

NATIONAL INSTITUTE OF OCEANOGRAPHY

WORMLEY, GODALMING, SURREY

ENGLAND

CRVFT

LANGUAGE - FORTRAN II

(COPY ON FILE AT NODC)

COMPUTER - GE 225

ROUTINE TO FIND EITHER BEST LEAST SQUARES FIT TO N POINTS WITHIN SPECIFIED STANDARD DEVIATION ISIGMA', OR FIT A SPECIFIED IM-CURVE, ORDER CURVE. FORMER EXECUTED BY M-CURVE NEGÁTIVE, LATTER BY M-CURVE NONNEGATIVE. IN EITHER CASE 'SD' IS ACTUAL STANDARD DEVIATION AS CALCULATED. AUTHOR-- F.K. KEYTE. LISTED IN APPENDIX 5 OF BIO COMPUTER NOTE 66-5-C. A 14-PAGE WRITEUP IS IN THE 'COPE' CATALOG (1965) OF WOODS HOLE OCEANOGRAPHIC INSTITUTION.

DIRECTOR

ATLANTIC OCEANOGRAPHIC LABORATORY

BEDFORD INSTITUTE

DARTMOUTH, NOVA SCOTIA, CANADA

LEAST SQUARES PLOT

LANGUAGE - FORTRAN

COMPUTER - IBM 7074

FITS AN N-DEGREE POLYNOMIAL (MAX. N=IO) OR AN EXPONENTIAL FUNCTION TO DATA POINTS (MAX. 300), PLOTTING THE ACTUAL CURVE AND THE COMPUTED CURVE FOR COMPARISON OR PLOTTING THE DATA POINTS ONLY TO HELP IDENTIFY THE TYPE OF CURVE THEY REPRESENT. OS NO. 10112 . AUTHOR-- JAMES S. WARDEN.

COMPUTER DEPARTMENT, CODE 083

NAVAL OCEANOGRAPHIC OFFICE

SUITLAND, MD. 20390

CALCULATING AND PLOTTING TIME-TREND CURVES

LANGUAGE - FORTRAN. FAP COMPUTER - IBM $7090 / 94$

COMPUTES AND PLOTS A SERIES OF SMOOTHED OR GRADUATEO CURVES BASED ON A SEQUENCE OF GEOLOGIC OBSERVATIONS. NINE SMOOTHING FORMULAE ARE USED WHICH CORRESPOND TO CYCLES OF INCREASING MAGNITUDE WITHIN THE DATA, FOR EACH OF TEN VARIABLES WITH UP TO 500 OBSERVATIONS PER VARIABLE. LEAST SQUARES ANALYSIS IS USED TO FIT A SERIES OF 3RD ORDER PULYNOMIALS TO THE DATA. STORAGE REQUIREMENTS-- 24,757 LOCATIONS. RUNNING TIME-- ABOUT 2 MINUTES TO COMPUTE ALL NINE CURVES FOR IOO OUSERVATIONS 
ON A SINGLE VARIABLE. AUTHOR-- WILLIAM T. FOX, WILLIAMS COLLEGE. (SPECIAL DISTRIBUTION PUBLICATION 12)

DR. DANIEL F. MERRIAM, EDITOR, COMPUTER CONTRIBUTIONS KANSAS GEOLOGICAL SURVEY

COMPUTER APPLICATIONS LABORATORY

THE UNIVERSITY OF KANSAS

LAWRENCE, KANSAS 66045

TREND-SURFACE PROGRAM WITH UNRESTRICTED INPUT

\author{
LANGUAGE - FORTRAN II \\ AND IV, AND \\ BALGOI_ \\ COMPUTER - IBM 1620
}

DIFFERS FROM PREVIOUS TREND-SURFACE PROGRAM FOR THE IBM 1620 (SPECIAL DISTRIBUTION PUBLICATION 14, BY D.I. GOOD, 1964) IN ONE MAJOR ASPECT-DATA ARE NOT STORED IN A DIMENSION ARRAY WITHIN THE COMPUTER, BUT ARE PROCESSED AND ACCUMULATED AS READ IN. THE PROGRAM, THEREFORE, IS THEORETICALLY CAPABLE OF INCORPORATING AN INFINITE NUMBER OF DATA POINTS. PRODUCES VALUES UP TO THE FOURTH-DEGREE EQUATIONS. STORAGE REQUIREMENTS-- APPROXIMATELY $18 \mathrm{~K}$ BITS. RUNNING TIME-- TWO PASSES ARE NECESSARY, REQUIRING ABOUT 12 MINUTES PER 100 DATA POINTS ON EACH PASS. AUTHORS-- ROBERT J. SAMPSON AND JOHN C. DAVIS, IDAHO STATE UNIV. REF.-SPECIAL DISTRIBUTION PUBLICATION 26 (1966)•

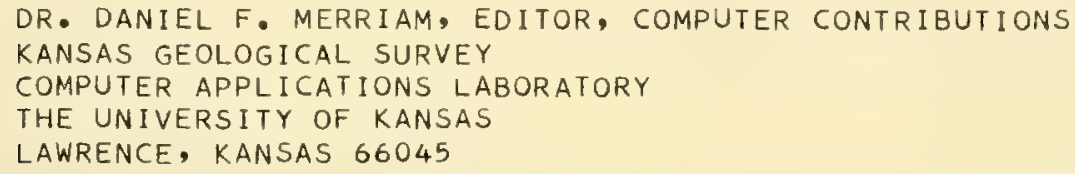

MULTIVARIATE NON-LINEAR REGRESSION

$$
\begin{aligned}
\text { LANGUAGE - } & \text { FORTRAN II } \\
& \text { AND IV } \\
\text { COMPUTER - } & \text { IBM } 709 \text { AND } \\
& \text { CDC } 6400
\end{aligned}
$$

COMPUTES MULTIVARIATE NON-LINEAR REGRESSION (TREND SURFACE) THROUGH THE QUINTIC WITH ANALYSIS OF VARIANCE FOR SELECTION OF BEST FIT, FOR $N=2500$.

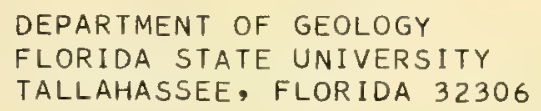

TREND SURFACES FOR DEGREES 1 THROUGH 6

$$
\begin{aligned}
& \text { LANGUAGE - FORTRAN IV } \\
& \text { COMPUTER - IBM } 7040
\end{aligned}
$$

POLYNOMIAL SURFACES ARE FITTED UP TO THE SIXTH DEGREE. THE SURFACES MAY BE CONTOURED AND THE RESIDUALS PLOTTED. RANGE IS UP TO 500 DATA POINTS. APPROXIMATELY 40 MINUTES ARE REQUIRED FOR 200 DATA POINTS FOR 7-1/2 BY 9 TREND-SURFACE MAPS THROUGH SIXTH DEGREE. STORAGE REQUIREMENTS FOR THE 7040-- 16K AND 4 MAG. TAPES. AUTHORS-- MONT OILEARY OF THE UNIV. OF KANSAS, R.H. LIPPERT OF SHELL OIL CO., OWEN T. SPITZ OF KANSAS GEOL. SURVEY. REVISED FROM D.I. GOODIS PROGRAM FOR THE IBMI620 WHICH WAS PUBLISHED IN 1964 AS KANSAS GEOLOGICAL SURVEY SPECIAL DISTRIBUTION PUBLICATION 14.

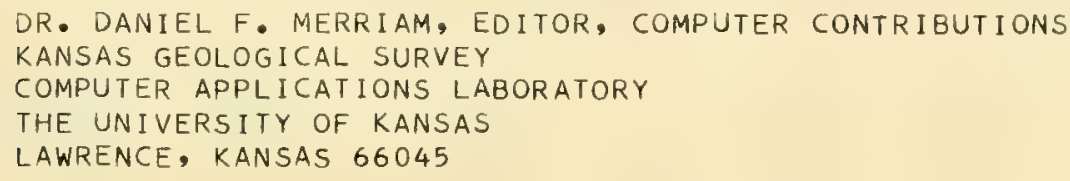


USES THE LEAST SQUARES TECHNIQUE TO FIT AN EQUATION TO GEOGRAPHICALLY DISPERSED DATA. OUTPUT INCLUDES PRINTED MAPS. AUTHOR-- W.R. TOBIEER.

THE UNIVERSITY OF MICHIGAN

DEPARTMENT OF GEOGRAPHY

ATTN. DR - W. R. TOBLER

ANN ARBOR, MICHIGAN 48104

***** mATHEMATICAL AND STATISTICAL ANALYSIS *****

SBWRO (SHIPBORNE WAVE RECORDER ANALYSIS)

LANGUAGE - FORTRAN IV

COMPUTER - IBM 1800 SYS

(COPY ON FILE AT NODC)

GIVEN VALUES OF THE HIGHEST AND SECOND HIGHEST CRESTS, THE LOWEST AND SECONO LOWEST TROUGHS, THE NUMBER OF ZERO CROSSINGS AND THE NUMBER OF CRESTS IN A SHORT RECORD FROM THE N.I.O. SHIPBORNE WAVE RECORDER, COMPUTES THE SPECTRAL WIDTH PARAMETER AND THE SIGNIFICANT WAVE HEIGHT AND ALSO THE PREDICTED MAXIMUM HEIGHT IN A PERIOD OF THREE HOURS, AND STORES THE RESULTS ON LINEPRINTER AND DISK. N.I.O. PROGRAAI NO. 89. AUTHOR-- EILEEN PAGE.

NATIONAL INSTITUTE OF OCEANOGRAPHY WORMLEY, GODALMING, SURREY

ENGLAND

HILOW (GENERATE ARBITRARY FILTER)

LANGUAGE - FORTRAN IV

(COPY ON FILE AT NODC)

GENERATES A LOWPASS, BANDPASS, OR HIGHPASS FILTER DEFINED BY 3 PARAMETERS, WITH OR WITHOUT ITS CONJUGATE, PUNCHES THE MULTIPLIERS ON CARDS, AND LISTS ITS AMPLITUDE RESPONSE OVER THE FULL FREQUENCY RANGE. N.I.O. PROGRAM NO. 158. AUTHOR- D.E. CARTWRIGHT.

NATIONAL INSTITUTE OF OCEANOGRAPHY

WORMLEY, GODALMING, SURREY

ENGLAND

SUBROUTINES DETRND, AUTCOV, CRSCOV, FOURTR

LANGUAGE - FORTRAN IV COMPUTER - IBM $360 / 40$

(COPY ON FILE AT NODC)

A SET OF PROGRAMS DEALING WITH SPECTRA. DETRND REMOVES THE MEAN, OR THE MEAN AND LINEAR TREND (SLOPE) FROM A TIME SERIES. AUTCOV COMPUTES THE AUTOCOVARIANCE OF THE TIME SERIES. CRSCOV COMPUTES THE AUTO- AND CROSS-COVARIANCES OF TWO SEQUENCES. FOURTR COMPUTES EITHER THE SINE OR COSINE FOURIER TRANSFORM. SMOOTHING OF EITHER IS OPTIONAL. LISTED AND DESCRIBED IN THE PUBLICATION 'WATER WAVE TEACHING AIDS', WHICH APPEARS AS TECHNICAL NOTE 13 OF THE M.I.T. HYDRODYNAMICS LABORATORY. THESE ROUTINES ARE ADAPTED FROM A PROGRAM WRITTEN AT BELL TELEPHONE LABS BY M.J.R. HEALY (1962).

PROF. RALPH H. CROSS

ROOM 48-209 HYDRODYNAMICS LABORATORY

MASSACHUSETTS INSTITUTE OF TECHNOLOGY

CAMBRIDGE, MASSACHUSETTS 02139

DIGITAL POWER SPECTRUM ANALYSIS

LANGUAGE - FORTRAN IV

COMPUTER - IBM 7090

THE PROGRAM WAS ORIGINALLY INTENDED TO ANALYZE UNDERWATER SOUND. THE HYDROPHONE OUTPUT IN ANALOG FORM IS FIRST DIGITIZED. THE PROGRAM THEN COMPUTES THE POWER SPECTRUM ESTIMATE UTILIZING THE FAST FOURIER TRANSFORM. THE POWER IS COMPUTED FOR A LINEAR SET OF FREQUENCIES. THIS 
INFORMATION IS WRITTEN ON AN OUTPUT TAPE.

DR. J. W. WRENCH, JR.

HEAD, MATHEMATICAL COMP. DIVISION

NAVAL SHIP RESEARCH AND DEVELOPMENT CENTER

WASHINGTON, D.C. 20007

STATISTICAL AND PEAK-TO-PEAK ANALYSIS

\author{
LANGUAGE - FORTRAN IV \\ AND MAP \\ COMPUTER - IBM 7090
}

USED IN THE ANALYSIS OF SHIP TRIAL DATA TO STUDY THE ELASTIC RESPONSES OF SURFACE SHIP STRUCTURES TO RANDOM SEA ENVIRONMENT. CALCULATES STATISTICAL AND PEAK TO PEAK PARAMETERS ASSOCIATED WITH DIGITIZED RANDOM DATA. PROCESSES UP TO 14 CHANNELS OF DATA CONCURRENTLY, AND ALLOWS SELECTION OF EITHER CALIBRATED OR UNCALIBRATED RESULTS. REF. NSRDC APPLIED MATHEMATICS LABORATORY TECHNICAL NOTE AML-35-69, MAY 1969, JBIM PROGRAM FOR STATISTICAL AND PEAK-TO-PEAK ANALYSIS', BY MICHAEL CHERNIK.

DR. J. W. WRENCH, JR.

HEAD, MATHEMATICAL COMP. DIVISION

NAVAL SHIP RESEARCH AND DEVELOPMENT CENTER

WASHINGTON, D.C. 20007

PARTIAL AND ORDINARY COHERENCE

$\begin{aligned} & \text { LANGUAGE - } \text { FORTRAN IV } \\ & \text { AND MAP } \\ & \text { COMPUTER - IBM } 7090\end{aligned}$

PROGRAM PRTCOH CALCULATES THE PARTIAL COHERENCE FOR RANDOM DATA FROM A LINEAR SYSTEM, AND OCOH CALCULATES THE ORDINARY COHERENCE FROM THE SAME DATA. THE DATA IS ASSUMED TO BE STATIONARY RANDOM DATA FROM A MULTIPLE-INPUT S:STEM WITH A SINGLE OUTPUT. BOTH PROGRAMS COMPUTE THE TRANSFER RESPONSE FUNCTION FOR EACH INPUT. REF. APPLIED MATHEMATICS LABORATORY TECHNICAL NOTE AML-31-69, MAY 1969, 'COMPUTER PROGRAMS FOR PARTIAL AND ORDINARY COHERENCE, BY ANTHONY C. MELODIA.

DR. J. W. WRENCH, JR. HEAD, MATHEMATICAL COMP. DIVISION NAVAL SHIP RESEARCH AND DEVELOPMENT CENTER WASHINGTON, D.C. 20007

SAVED (SHOCK AND VIBRATIONAL EXPERIMENTAL DATA REDUCTION)

\author{
LANGUAGE - FORTRAN IV \\ AND MAP \\ COMPUTER - IBM 7090
}

REDUCES BLAST TEST DATA FROM ANY ONE OF FOUR TYPES OF TRANSDUCERS-VELOCITY METERS, ACCELEROMETERS, PRESSURE GAUGES AND STRAIN GAUGES. THROUGH PROGRAMMED OPTIONS THE INPUT DATA, AFTER BEING CALIBRȦTED, MAY BE SMOOTHED, FILTERED OR LISTED BEFORE BEING PLOTTED AS A FUNCTION OF TIME. FOR VELOCITY DATA, TRANSDUCER CORRECTIONS WERE APPLIED AND DISPLACEMENT IS COMPUTED AND PLOTTED. FOR ACCELERATION DATA, VELOCITY AND DISPLACEMENT ARE COMPUTED AND PLOTTED. INPUT DATA IS READ FROM A DIGITAL MAGNETIC TAPE IN A PREDEFINED FORMAT. DESCRIPTION IS IN NSRDC APPLIED MATHEMATICS LABORATORY TECHNICAL NOTE AML-14-69, MARCH 1969, ENTITLED 'A DIGITAL PROGRAM FOR REDUCING SHOCK AND VIBRATIONAL EXPERIMENTAL DATA' BY ANTHONY $V$. CINCOTTA.

DR. J. W. WRENCH, JR.

HEAD, MATHEMATICAL COMP. DIVISION

NAVAL SHIP RESEARCH AND DEVELOPMENT CENTER

WASHINGTON, D.C. 20007 
N.P.G.S. LIBRARY PROGRAM. COMPUTES, FOR TWO SIMULTANEOUS TIME SERIES. CROSS SPECTRA, POWER SPECTRA, PHASE AND COHERENCE. SUBPROGRAMS OBTAIN THE FILTERED SERIES, REMOVE THE TREND, AND COMPUTE THE AUTO- AND CROSS CORRELATIONS. THESIS BY JOHN G. MCMILLAN (JUNE 1968 ) USES DIGITAL. ANALYSIS BY PROGRAM BLACKY IN THE STUDY OF TEMPERATURE FLUCTUATIONS NEAR THE AIR-SEA INTERFACE, THE WAVE FIELD AT THE SAME POINT, AND THE DOWNSTREAM WIND VELOCITY.

NAVAL POSTGRADUATE SCHOOL MONTEREY, CALIFORNIA 93940

SPECTRAL ANALYSIS OF TIME SERIES

$$
\begin{aligned}
\text { LANGUAGE - } & \text { FORTRAN IV } \\
& \text { AND ALGOL } 60 \\
\text { COMPUTER - } & \text { UNIVAC } 1108 \\
& \text { AND B5500 }
\end{aligned}
$$

( COPY ON FILE AT NODC)

FINDS THE SPECTRA, COSPECTRA, QUADSPECTRA, COHERENCE, AND PHASE OF TWO TIME SERIES OR A SINGLE SPECTRUM OF ONE SERIES. USES THE FAST FOURIER TRANSFORM (ALGORITHM OF COOLEY AND TUKEY, 1965). REF. SPECIAL REPORT

NO. 6, MARCH 1969 , BY EVERETT J. FEE.

THE LIBRARIAN

CENTER FOR GREAT LAKES STUDIES

UNIVERSITY OF WISCONSI NV-MILWAUKEE

MILIVAUKEE, WISCONSIN 53201 USA

WAVEIN AND DIFRAK

$$
\begin{aligned}
\text { LANGUAGE - } & \text { FORTRAN } \\
\text { COMPUTER - } & \text { IBM } 7094 \text { AND } \\
& \text { CDC } 6400
\end{aligned}
$$

A PAIR OF PROGRAMS FOR (1) SPECTRAL ANALYSIS OF WAVE DATA, AND (2) COMPUTATION AND PLOT OF THE DIFFRACTION COEFFICIENTS. AIJTHOR-- SHOU-SHAN

FAN, C.E.R.C., WASH, D.C.

PROF. ROBERT L. WIEGEL

DEPARTMENT OF CIVIL ENGINEERING

UNIVERSITY OF CALIFORNIA

BERKELEY, CALIF. 94720

POWER SPECTRUM ANALYSIS

$$
\begin{aligned}
\text { LANGUAGE - } & \text { FORTRAN AND } \\
& \text { BINARY } \\
\text { COMPUTER - } & \text { IBM } 7090 \\
& \text { AND IBM } 704
\end{aligned}
$$

USED IN THE ANALYSIS OF DCEAN WAVE RECORDS, WHICH GIVE THE FLUCTUATION OF THE HYDROSTATIC PRESSURE AT A POINT UNDER THE SEA AS A FUNCTION OF TIME. DIVIDED INTO TWO PROGRAMS-- AML PROBLEM 840-017C COMPUTES ONLY THE AUTOCORRELATION AND SPECTRAL ESTIMATES FOR EACH SINGLE TIME SERIES, AML PROBLEM 840-157B COMPUTES, IN ADDITION, THE TWO CROSS-CORRELATIONS, NAMELY, THE IN-PHASE SPECTRUM (CO-SPECTRUM) AND THE OUT-OFPHASE SPECTRUM (QUA-SPECTRUM) FOR THE SIMULTANEOUS TIME RECORDS, ALSO COMPUTES THE MEASURE OF COHERENCY OF THE SYSTEM. REF. AML REPORT 131 $(1963)$, 'IBM 704 POWER-SPECTRUM ANALYSIS'.

MR. GENE H. GLEISSNER

HEAD, APPLIED MATHEMATICS LABORATORY

NAVAL SHIP RESEARCH AND DEVELOPMENT CENTER

WASHINGTON, D.C. 20007 
EERING COMPANY DATA FORMAT TRANSLATOR (ANALOG-DIGITAL) • (PROGRAM DOCUMENTED BUT CONTROLLED FOR DISTRIBUTION BECAUSE OF CLASSIFIED APPLICATIONS OF THE SPECIALLY DEVELOPED MATHEMATICAL TECHNIQUES USED)

MR. GENE H. GLEISSNER

HEAD, APPLIED MATHEMATICS LABORATORY

NAVAL SHIP RESEARCH AND DEVELOPMENT CENTER

WASHINGTON, D.C. 20007

POWER SPECTRUM ANALYSIS

LANGUAGE - BASIC

COMPUTER - PB-250

(COPY ON FILE AT NODC)

COMPUTES POWER SPECTRA, CROSS-SPECTRA, AND COHERENCIES. THE METHOD OF TUKEY IS USED TO CALCULATE THE REQUIRED SINGLE AND CROSS SPECTRA. THE MAXIMUM NUMBER OF LAGS ALLOWED IS 240 FOR SINGLE SPECTRUM AND 128 FOR CROSS-SPECTRA. MEMORY SIZE-- 6960. AUTHOR-- S.R. CLARK. REF. TECHNICAL MEMORANDUM 64-5 (JULY 1964). ALSO INCLUDED IN THE TECH. MEMO. ARE PRETREATMENT AND CALIBRATION PROGRAMS. REF. ALSO PNL LAB. NOTE 61-11 POWER SPECTRUM ANALYSIS WITH THE LGP-30 .

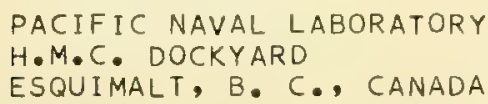

POWER SPECTRA ESTIMATION

$$
\begin{aligned}
& \text { LANGUAGE - FORTRAN } \\
& \text { COMPUTER - CDC } 3200
\end{aligned}
$$

COMPUTES SPECTRUM AND AUTO-CORRELATION OF ONE TIME SERIES AND/OR THE SPECTRA, CO-SPECTRUM, QUADRATURE SPECTRUM, AUTO-CORRELATION AND CROSSCORRELATION OF TWO SIMULTANEOUS TIME SERIES. PERFORMS FOURIER TRANSFORM ON COVARIANCE FUNCTIONS (TUKEY SPECTRUM ESTIMATION) ALSO PERFORMS SMOOTHING ON SPECTRA BY METHOD CALLED 'HANNING' - NO OFFICIAL DOCUMENTATION HAS BEEN PUBLISHED.

NAVAL UNDERWATER WEAPONS RESEARCH

AND ENGINEERING STATION

ATTN. CODE DA3B

NEWPORT, RHODE ISLAND 02840

HARMONIC ANALYSIS

LANGUAGE - MAC

COMPUTER - ICT 1301

HARMONIC ANALYSIS USING SHUSTER'S CRITERION FOR THE DETERMINATION OF SIGNIFICANT AMPLITUDES. AUTHORS-- A.M• SHIPLEY AND D. SACKS.

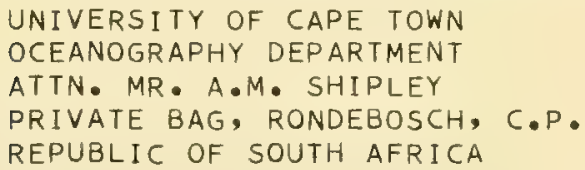

A SET OF FOUR PROGRAMS WHICH COMPUTES THE AUTO- AND CROSS-SPECTRAI_ESTIMATES FOR TIME SERIES, FOR 1 TO 2048 FREQUENCIES.

INFORMATION PROCESSING CENTER

ATTN. ROBERT MILLARD

WOODS HOLE OCEANOGRAPHIC INSTITUTION

WOOOS HOLE, MASSACHUSETTS 02543 
(COPY ON FILE AT NODC)

PROGRAM USED TO ESTIMATE THE SPECTRUM OF CURRENT RECORDS THAT ARE IRREGULARLY SAMPLED, AND WITH EXTENSIVE GAPS, BY A NEW FORM OF COMPI_EX DEMODULATION, ALLOWING EXAMINATION OF PERIODS UP TO 100 DAYS. SPECIAL APPLICATION TO THE SEARCH FOR THE EXISTENCE OF EQUIVALENT-BAROTROPIC TOPOGRAPHIC (ROSSBY) WAVES ON THE WESTERN SIDE OF THE NORTH ATLANTIC. THE AUTOSPECTRA LEVEL OFF AT LOWEST FREQUENCIES, NO LONGER INCREASING AS A POWER LAW. STRONG COHERENCES WERE FOUND AT LOW FREQUENCIES BETWEEN THE U AND $V$ COMPONENTS AND BETWEEN THE LEVELS. REF. A TECHNICAL REPORT NO. 69-67 (UNPUBLISHED MANUSCRIPT), AUG 1969, BY RORY THOMPSON.

DR. N.P. FOFONOFF, CHAIRMAN

DEPT. OF PHYSICAL OCEANOGRAPHY

WOODS HOLE OCEANOGRAPHIC INSTITUTION

WOODS HOLE, MASSACHUSETTS 02543

\title{
CIRCSTAT
}

\author{
LANGUAGE - FORTRAN IV \\ COMPUTER - CDC 3400
}

(COPY ON FILE AT NODC)

COMPUTES THE SIGNIFICANT STATISTICS FOR CIRCULAR NORMALLY DISTRIBUTED DATA, AS WELL AS GIVING CALCULATIONS FOR USE IN TESTING HYPOTHESES. A CONTROL CARD DETERMINES THE TEST PERFORMED. IN ALL CASES, THE VECTOR DIRECTION, VECTOR LENGTH, AND VECTOR STRENGTH ARE COMPUTED. TESTS OF PREFERRED ORIENTATION ARE CONDUCTED BY THE RAYLEIGH R-TEST OR BY THE GREENWOOD-DURAND U-TEST. BIMODAL DATA MAY BE TREATED BY PROGRAM CIRCSTAT. REF. TECHNICAL REPORT NO. 3, OFFICE OF NAVAL RESEARCH, FEB. 1967, BY THOMAS A. JONES.

DEPARTMENT OF GEOLOGY

NORTHWESTERN UNIVERSITY

EVANSTON, ILLINOIS 60201

BOMM (TIME SERIES)

\author{
LANGUAGE - FORTRAN, \\ COMPASS \\ COMPUTER - IBM OS/360, \\ CDC 3600
}

A COLLECTION OF PROGRAMS HAVING TIME SERIES AS OPERANDS PRIMARIILY DESIGNED FOR ANALYSIS, CORRELATION AND DECOMPOSITION OF RECORDS. COPIES AVAILABLE THROUGH 'SHARE' AND 'COOP'. AUTHORS-- SIR EDWARD BULLARD, MRS. FLORANCE OGALBY DORMER, WALTER MUNK AND GAYLORD MILLER.

MRS. FLORENCE O. DORMER

INSTITUTE OF GEOPHYSICS AND PLANETARY PHYSICS

SCRIPPS INSTITUTION OF OCEANOGRAPHY

P.O. BOX 109

LA JOLLA, CALIFORNIA 92037

\begin{abstract}
ANALYSIS OF NON-LINEAR RESPONSE SURFACE
LANGUAGE - FORTRAN IV

(COPY ON FILE AT NODC)

COMPUTER - IUM 1130

ANALYZES THE DATA FROM RESPONSE SURFACE EXPERIMENTS WHEN TWO OR THREE FACTORS ARE MEASURED. OPTIONS ALLOW CALCULATION OF MAXIMUM LIKELIHOOD ESTIMATES OF POWER TRANSFORMATIONS OF BOTH INDEPENDENT ANO DEPENDENT VARIABLES, AND THE PLOTTING OF THEIR RELATIVE MAXIMUM LIKELIHOOD GRAPHS, AS A MEASURE OF THE PRECISION OF THE ESTIMATES. THE DATA IS THEN SUBJECTED TO ANALYSIS OF VARIANCE, USING ORTHOGONAL POLYNOMIALS, AND PRINCIPAL COMPONENT ANALYSIS, AND SPECIFIED CONTOURS OF THE DEPENDENT VARIABLE ARE PLOTTED, BOTH WITHOUT AND WITH TRANSFORMATION. REF. FRB TECHNICAL REPORT NO. 87 (PUBLISHED MANUSCRIPT, AUG 1968) BY J. K. LINDSEY. DIRECT INQUIRIES TO--
\end{abstract}

FISHERIES RESEARCH BOARD OF CANADA

BIOLOGICAL STATION

NANAIMO, B. C. 
(COPY ON FILE AT NODC)

A COMPLETE MULTIPLE DISCRIMINANT ANALYSIS IS PERFORMED BY SIX INTERRELATED PROGRAMS WHICH ARE EXECUTED IN SUCCESSION THROUGH THE LINK FEATURE IN 1130 FORTRAN. WILL ACCEPT UP TO 25 VARIATES AND AS MANY AS 10 GROUPS. ANY NUMBER OF ADDITIONAL DATA CARDS CAN BE READ AND PROCESSED AFTER THE DISCRIMINANT ANALYSIS HAS BEEN COMPLETED. THE VALUE OF THE DISCRIMINANT FUNCTION. CLASSIFICATION CHI-SQUARES AND PROBABILITIES OF GROUP MEMBERSHIP ARE COMPUTED AND PRINTED FOR EACH ADDITIONAL M-VARIATE OBSERVATION. AUTHORS-- L.V. PIENAAR AND J.A. THOMSON, FRB TECHNICAL REPORT NO. 112, MAR 1969 (UNPUBLISHED MANUSCRIPT). DIRECT INQUIRIES TO--

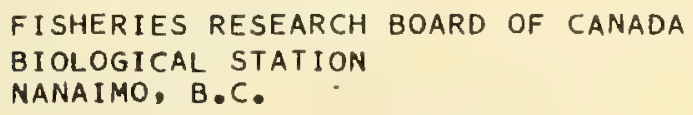

SCALING SUBROUTINE

LANGUAGE - FORTRAN

SCALES AN ARRAY OF FLOATING POINT NUMBERS, CORRESPONDING TO A SINGLE COORDINATE, PREPARING THEM FOR INPUT TO THE 565 CALCOMP PLOTTER. NRL MEMO. REPORT 2047. AUTHORS-- J. LANGWORTHY, J. HOUSTON.

JAMES B. LANGWORTHY

THEORY BRANCH

NUCLEAR PHYSICS DIVISION

NAVAL RESEARCH LABORATORY, WASHINGTON, D. C. 20390

EVALUATE BESSEL FUNCTIONS

LANGUAGE - FORTRAN

COMPUTER - CDC 3800

A SET OF SUBROUTINES THAT EVALUATE, IN SINGLE AND DOUBLE PRECISION, BESSEL FUNCTIONS OF THE FIRST AND SECOND KINDS FOR ORDERS ZERO AND ONE FOR POSITIVE REAL ARGUMENTS. ALSO TO EVALUATE, IN 5 INGLE AND DOUBLE PRECISION, BESSEL FUNCTIONS OF THE FIRST AND SECOND KINDS FOR INTEGER OR FRACTIONAL ORDERS AND POSITIVE REAL ARGUMENTS. NRL MEMO • REPORTS 1975-1978. AUTHORS-- J. MASON, R. BRIER.

JANET P. MASON

RESEARCH COMPUTATION CENTER

MATHEMATICS AND INFORMATION SCIENCES DIVISION

NAVAL RESEARCH LABORATORY, WASHINGTON, D. C. 20390

DETERMINANT OF A REAL SYMMETRIC MATRIX

$$
\begin{aligned}
& \text { LANGUAGE - FORTRAN } \\
& \text { COMPUTER - CDC } 3800
\end{aligned}
$$

A SUBROUTINE WRITTEN AT ARGONNE NATIONAL LABORATORY THAT SOLVES, INVERTS, AND FINDS THE DETERMINANT OF SYMMETRIC REAL MATRICES, HAS BEEN MODIFIED. IT REQUIRES THAT ONLY THE UPPER TRIANGULAR PORTION OF THE MATRIX BE INPUT, THEREBY REDUCING THE MATRIX STORAGE REQUIREMENT TO $\mathrm{N}(\mathrm{N}+1) / 2$ LOCATIONS. NRL MEMO. REPORT 2009. AUTHOR-- J. MASON

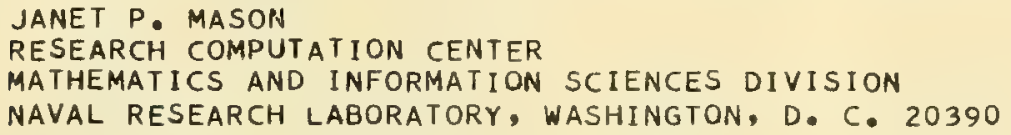

SUBROUTINE TO FIND THE REAL ZEROS OF A

LANGUAGE - FORTRAN

SINGLE-VALUED FUNCTION OF ONE REAL VARIABLE

COMPUTER - CDC 3800

FINDS THE REAL ZEROS OF A SINGLE-VALUED FUNCTION OF ONE REAL VARIABLE BY A MODIFIED METHOD OF FALSE POSITION. FINDS WITHIN A SPECIFIED TOL- 
ERANCE (DELTA) THOSE POINTS XII) ALONG A GIVEN CLOSED INTERVAL FOR WHICH THE FUNCTIONAL VALUE FXII) SATISFIES THE ABSOLUTE VALUE OF FX(I) LESS THAN DELTA. EACH POINT AND THE CORRESPONDING FUNCTIONAL VALUE ARE STORED IN A TABLE. NRL MEMO. REPORT 1974. AUTHORS-- J. MASON, H. TOOTHMAN.

JANET P. MASON

RESEARCH COMPUTATION CENTER

MATHEMATICS AND INFORMATION SCIENCES DIVISION

NAVAL RESEARCH LABORATORY, WASHINGTON, D. C. 20390

CROSS-ASSOCIATION OF NONNUMERIC SEQUENCES

$$
\begin{aligned}
\text { LANGUAGE - } & \text { ALGOL } 60 \text { AND } \\
\text { COMPUTER - } & \text { ELRTRAN IV } \\
& \text { IBM } 7040 / 44
\end{aligned}
$$

READS A PAIR OF SEQUENCES WHOSE ELEMENTS BELONG TO A NONORDERED SET. THE DATA ARE READ IN A NUMERIC CODE. THE PROGRAM SLIDES THE SEQUENCES PAST EACH OTHER ONE OR MORE STEPS AT A TIME AND FOR EACH MATCH POSITION COUNTS THE NUMBER OF COMPARISONS (SIZE OF OVERLAP). VARIOUS SIGNIFICANCE MEASURES AND OVERALL SIMILARITY ESTIMATES ARE MADE. AUTHORSM.J. SACKIN AND P.H.A. SNEATH, UNIV. OF LEICESTER, D.F. MERRIAM, KANSAS GEOL. SURVEY. REF. SPECIAL DISTRIBUTION PUBLICATION 23 (1965).

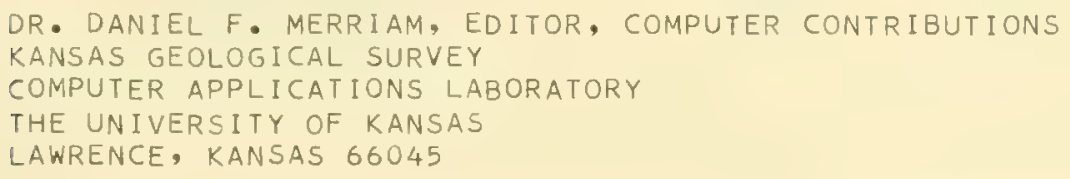

SIMULATION OF TRANSGRESSION AND REGRESSION WITH

LANGUAGE - FORTRAN IV

CONTINUOUS-TIME MARKOV MODELS

COMPUTER - CDC 6400

REPORT (COMPUTER CONTRIBUTION 26) IS CONCERNED WITH A STOCHASTIC SIMULATION MODEL IN WHICH THE PATTERN OF LITHOLOGIC SUCCESSION IS EXAMINEO IN TERMS OF THE LENGTH OF TIME THAT THE SYSTEM REMAINS IN A GIVEN STATE, ONCE IT HAS ENTERED THAT STATE. THE MODEL IS ALSO BASED ON TRANSGRESSIVE-REGRESSIVE MOTION OF A SHORELINE (OR STRANDLINE), WITH THE RESULTING LITHOLOGIC UNITS DEVELOPING AS RESPONSES TO THE MOVEMENT OF SEDIMENTARY MARINE OR NONMARINE ENVIRONMENTS LATERALLY AND THROUGH TIME. AUTHOR-- W.C. KRUMEEIN. TWO COMPUTER PROGRAMS ARE LISTED IN THE APPENDIX, ONE FOR TRANSFORMING A TRANSITION PROBABILITY MATRIX TO ITS CORRESPONDING TRANSITION RATE MATRIX AND VICE VERSA, AND THE OTHER ('BOREHOLE') FOR SIMULATING LATERAL-SHIFT PHENOMENA, SUCH AS TRANSGRESSION AND REGRESSION WITH A CONTINUOUS-TIME DISCRETE-STATE MARKOV MODEL.

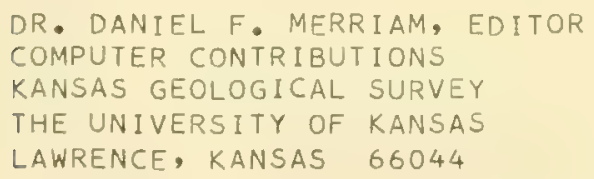

POWER SPECTRUM OF GEOLOGICAL SURFACES

$$
\begin{aligned}
\text { LANGUAGE - } & \text { FORTRAN IV } \\
\text { COMPUTER - } & \text { GE } 625 \text { AND } \\
& \text { IBM } 7040
\end{aligned}
$$

TWO-DIMENSIONAL POWER SPECTRUM IS USED FOR NUMERICAL DESCRIPTION OF OBSERVED SURFACES. DATA MUST BE GRIDDED - MAXIMUM IS 100 BY 100 POINTS. RUNNING TIME FOR MAXIMUM ARRAY IS ABOUT 20 MINUTES ON GE 625. COMPUTER CONTRIBUTION 16, BY J.E. ESLER AND F.W. PRESTON, 1967.

DR. UANIEL F. MERRIAM, EDITOR

COMPUTER CONTRIBUTIONS

KANSAS GEOLOGICAL SURVEY

THE UNIVERSITY OF KANSAS

LAWRENCE, KANSAS 66044 
HARMONIC ANALYSIS USEFUL FOR DATA SUSPECTED OF CONTAINING OSCILLATORY PHENOMENA. DESIGNED FOR DATA OBTAINABLE ON A REGULARLY SPACEU, RECTANGULAR GRID. THE PROGRAM COMPUTES COEFFICIENTS OF FOURIER SERIES AND EVALUATES AND PLOTS THE FUNCTION. ALSO COMPUTES AND PLOTS RESIDUAL VALUES. ALLOWS UP TO $71 \times 73$ GRID POINTS AND UP TO $25 T H$ HARMONIC IN BOTH DIRECTIONS. COMPUTER CONTRIBUTION 29 , BY JOHN W. HARBAUGH AND MICHAEL J. SACKIN (JUNE 1968). AN EARLIER PROGRAM WAS DEVELOPED FOR DOUBLE FOURIER SERIES ANALYSIS OF SURFACES WITH IRREGULARLY SPACED DATA. REF. COMPUTER CONTRIBUTION 5, BY W.R. JAMES (1966).

DR. DANIEL F. MERRIAM, EDITOR

COMPUTER CONTRIBUTIONS

KANSAS GEOLOGICAL SURVEY

THE UNIVERSITY OF KANSAS

LAWRENCE, KANSAS 66044

\author{
FOURIER ANALYSIS - PROGRAM L 101 \\ LANGUAGE - FORTRAN \\ COMPUTER - IBM 7090
}

(COPY ON FILE AT NODC)

OBTAINS AMPLITUDES AND PHASES OF FREQUENCY COMPONENTS IN ANY RECORD. STANDARD FOURIER ANALYSIS PLUS USE OF TUKEY COSINE WINDOW TO REDUCE EDGE EFFEGTS. CORE STORAGE USED-- 32K. AUTHOR-- ALSOP.

LAMONT-DOHERTY GEOLOGICAL OBSERVATORY

COLUMBIA UNIVERSITY

PALISADES, NEW YORK 10964

(COPY ON FILE AT NODC)

CARRIES OUT A SINGLE LINKAGE CLUSTER ANALYSIS USING DATA IN THE FORM OF AN UPPER TRIANGULAR SIMILARITY MATRIX. OUTPUT-- A) SIMILARITY LEVEL OF CLUSTERING CYCLE, B) A LIST OF THE LINKAGES THAT OCCUR AT THAT SIMILARITY LEVEL, C) AT THE END OF THE CYCLE THE CLUSTER NUMBERS AND A LIST OF THE ENTITIES MAKING UP EACH CLUSTER IS PRINTED. RUN TIME-A MATRIX OF ORDER 60 TOOK APPROXIMATELY 15 MINUTES TO CLUSTER. N.I.O. PROGRAM NO. 166. AUTHOR-- M. FASHAM.

NATIONAL INSTITUTE OF OCEANOGRAPHY WORMLEY, GODALMING, SURREY

ENGLAND

CLASSIFIES OBJECTS INTO GROUPS ON THE BASIS OF A LARGE NUMBER OF NONQUANTITATIVE CHARACTERS. HAS BEEN USED FOR GEOLOGICAL SAMPLES, BIOLOGICAL TAXONOMY, ETC. RANGE LIMITED TO 130 OBJECTS AND 100 ATTRIBUTES. OUTPUT MAY BE USED TO DRAW DENDROGRAMS WITH A CALCOMP PLOTTER. REF. COMPUTER CONTRIBUTION 17. AUTHOR-- G.F. BONHAM-CARTER, STANFORD UNIVERS ITY.

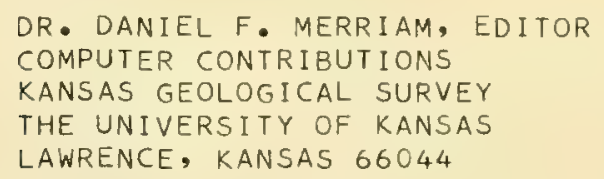


COMPUTES THE MULTIVARIATE DISCRIMINANT FUNCTION AND MAHALANOBISI GENERALIZED DISTANCE FOR TWO GROUPS, ANALYZES THE SIGNIFICANCE OF THE DIFFERENCE BETWEEN THE GROUPS, AND CLASSIFIES INDIVIDUAL SAMPLES• 20 VARIABLES MAY BE CONSIDERED SIMULTANEOUSLY. THE TWO SAMPLE GROUPS MAY CONTAIN ANY NUMBER OF SAMPLES. MATRIX INVERSION IS AVOIDED BY USING A MODIFICATION OF A PROCEDURE SUGGESTED DY RAO IN WHICH SAMPLES ARE OPERATED UPON ONE AT A TIME. USES POOLED ESTIMATES OF VARIANCE AND COVARIANCE IN A SERIES OF SIMULTANEOUS EQUATIONS, WHICH ARE SOLVED BY THE GAUSS-JORDAN METHOD OF APPROXIMATIONS. CORE STORAGE USED-- $20 \mathrm{~K}$. AUTHORS-- J.C. DAVIS AND R.J. SAMPSON, COMPUTER CONTRIBUTION NO. 4•

DR. DANIEL F. MERRIAM, EDITOR, COMPUTER CONTRIBUTIONS

KANSAS GEOLOGICAL SURVEY

THE UNIVERSITY OF KANSAS

LAWRENCE, KANSAS 66044

TWO-DIMENSIONAL AUTOCORRELATION

$\begin{aligned} \text { LANGUAGE - } & \text { FORTRAN } \\ \text { COMPUTER - } & \text { IBM } 7090 \text { AND } \\ & \text { IBM } 1401\end{aligned}$

(COPY ON FILE AT NODC)

APPLIES REGRESSION AND CORRELATION ANALYSES TO A SAMPLE OF OCEAN TERRAIN. COMPUTES VARIANCE AND COVARIANCE AS FUNCTION OF POSITION IN DATA FIELD. REF. ARTHUR D. LITTLE, INC. TECHNICAL REPORT NO. 1440464 - ISTATISTICAL ANALYSES OF OCEAN TERRAIN AND CONTOUR PLOTTING PROCEDURES . APPENOICES B AND C OF REPORT DESCRIBE (BUT DO NOT LIST) TWO ROUTINES USED - ICORRELATION CONSTANTSI (IBM 7090 FORTRAN) AND 'LOCAL MEANS AND VARIANCES' (IBM 1401 FORTRAN). THE A.D. NO. IS AU-601-538. COPIES HAVE BEEN DEPOSITED WITH THE DEFENSE DOCUMENTATION CENTER.

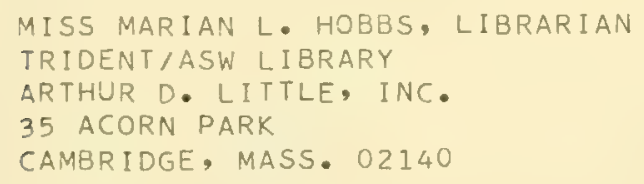

STATISTICS I, II, III

LANGUAGE - FORTRAN IV

COMPUTER - CDC 3100

(COPY ON FILE AT NODC)

THREE SEPARATE PROGRAMS FOR THE PROCESSING OF LIMNOLOGICAL DATA. THEY CALCULATE MEANS, STANDARD DEVIATIONS, STANDARD ERRORS AND OTHER STATISTICS OF VARIOUS LIMNOLOGICAL PARAMETERS. STATISTICS I GIVES WEIGHTED CRUISE-MEAN VALUES, CRUISE-MEAN EPILIMNION AND HYPOLIMNION VALUES, TABULATIONS OF THE RELATION BETWEEN TEMPERATURE AND OTHER PARAMETERS, AND NEAR-BOTTOM MEANS. STATISTICS II IS ESPECIALLY DESIGNED TO STUDY REGIONAL ANOMALIES IN THE DISTRIBUTION OF ANY PARAMETER. STATISTICS II IS A MORE SPECIALIZED PROGRAM ANALYSING THE VARIABILITY IN A SET OF DATA IN TERMS OF RANDOM AND SYSTEMATIC COMPONENTS. INPUT-- DATA ON TAPE IN CODC FORMAT. PROGRAMS DESCRIBED IN MANUSCRIPT REPORT NO. 13 $(1970)$, BY DR. H. E. SWEERS.

MARINE SCIENCES BRANCH

DEPARTMENT OF ENERGY, MINES AND RESUURCES

615 BOOTH STREET

OTTAWA, ONTARIO, CANADA

PROVIDES ELEMENTARY STATISTICS FOR THREE TIME SERIES OF CURRENT TEMPERATURE, SPEED, AND DIRECTION. MEANS ARE COMPUTED HOURLY, DAILY AND FOR THE ENTIRE SERIES. A HISTOGRAM IS PROVIDED DAILY AND FOR THE SERIES. VARIANCE AND STANDARD DEVIATION ARE COMPUTED FOR THE SERIES. OPTIONAL GRAPHICAL OUTPUTS HISTOGRAMS ARE PROVIDED. APPLICATIONS ARE MADE TO CONTINUOUS BOTTOM CURRENT MEASUREMENTS IN A SUBMARINE CANYON AND CONCURRENT WIND, WAVE, AND TIDAL DATA, IN THESES BY J.J. DOOLEY, JUPH 1968, AND 8Y I.J. NJUS, DEC 1968 . 
NAVAL POSTGRADUATE SCHOOL

MONTEREY, CALIFORNIA 93940

SINGLE INTEGRATION

LANGUAGE - FORTRAN

COMPUTER - IBM 7074

EQUALLY SPACED TIME SERIES DATA IS INTEGRATED ONCE USING TICK'S METHOD. THE DATA MUST BE SAMPLED AT A RATE OF AT LEAST TWICE THE NYQUIST FREQUENCY. OS NO. 53477. AUTHOR-- D.B. ROSS. REF. IM NO. 66-36.

EXPLORATORY OCEANOGRAPHY DIV., CODE 7200

NAVAL OCEANOGRAPHIC OFFICE

SUITLAND, MD. 20390

STATS

LANGUAGE - FORTRAN IV-H

COMPUTER - SDS SIGMA 7

COMPUTES AND LISTS STATISTICAL QUANTITIES RELATED TO VARIABLES STORED ON TAPE IN WHOI STANDARD DATA FORMAT.

INFORMATION PROCESSING CENTER

ATTN. JOHN A. MALTAIS

WOODS HOLE OCEANOGRAPHIC INSTITUTION

WOODS HOLE, MASSACHUSETTS 02543 
(COPY ON FILE AT NODC)

A SET OF PROGRAMS FOR VARIOUS ASPECTS OF SATELLITE NAVIGATION. THE PROGRAMS FALL NATURALLY INTO TWO SECTIONS, THOSE INVOLVED IN THE ONLINE REDUCTION OF DATA FROM THE SATELLITE AND THOSE INVOLVED IN THE ANALYSIS BOTH ON-LINE AND OFF-LINE. REF. N.I.O. REPORT N.20, AUG 28 1969.

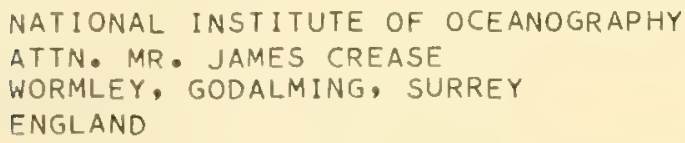

ALERT

LANGUAGE - FORTRAN IV COMPUTER - IBM 1130

(COPY ON FILE AT NODC)

CALCULATES THE RISE AND SET TIMES AND TIME OF CLOSEST APPROACH OF SATELLITES. OUTPUT FROM PROGRAM IS A LISTING OF ALERT INFORMATION, AND PUNCH CARDS FOR NEXT PROGRAM 'ASORT'. CORE STORAGE USED-- 5836 WORDS.

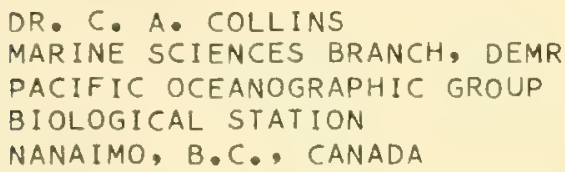

ASORT

LANGUAGE - FORTRAN IV

COMPUTER - IBM 1130

(COPY ON FILE AT NODC)

SORTS THE OUTPUT OF RISE TIMES OF SATELLITES FROM THE PROGRAM 'ALERT, IN CHRONOLOGICAL ORDER• A LISTING IS PRINTED ON THE IBM 1132. CORE STORAGE REQUIREMENTS-- 12,040 WORDS. DESCRIPTIONS OF BOTH PROGRAMS ARE IN FRB MANUSCRIPT REPORT NO. 1071 (DEC 1969), BY C.A. COLLINS, R. L.K. TRIPE, AND S•K. WONG (UNPUBLISHED MANUSCRIPT) •

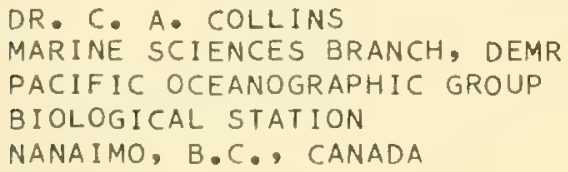

BECNAV (BEACON NAVIGATION PROGRAM)

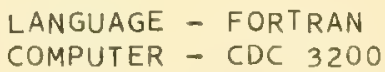

(COPY ON FILE AT NODC)

COMPUTES THE SHIPS POSITION AT EACH FIX FROM TWO OR MORE BEACONS WHOSE POSITION HAS BEEN ACCURATELY DETERMINED. A FIX CONSISTS OF THE DELAY TIMES FROM TWO OR MORE BEACONS. CORE STORAGE NEEDED-- ABOUT 8K WORDS. AUTHOR-- S. KOCHANSKI, NSSNF. IPROGRAM DOCUMENTAT ION UNCLASSIFIED BUT DISTRIBUTION CONTROLLED BY NSSNF,

\section{COMMANDING OFFICER}

NAVAL STRATEGIC SYSTEMS NAVIGATION FACILITY

FLUSHING AND WASHINGTON AVENUES

BROOKLYN, NEW YORK 11251 
TICES FROM THREE BEACONS. LIMIT, 40 FIXES PER TRACK. CORE STORAGE NEEDED-- ABOUT $14 \mathrm{~K}$ WORDS. AUTHOR-- 5. KOCHANSKI, NSSNF. IPROGRAM DOCUMENTATION UNCLASSIFIED BUT DISTRIBUTION CONTROLLED BY NSSNF,

COMMANDING OFFICER

NAVAL STRATEGIC SYSTEMS NAVIGATION FACILITY

FLUSHING AND WASHINGTON AVENUES

BROOKLYN, NEW YORK 11251

\section{SPANS $1 B$}

LANGUAGE - FORTRAN

( COPY ON FILE AT NODC)

COMPUTER - CDC 3200

TRANSLATES AND ROTATES A SET OF BEACON COORDINATES FROM LOCAL COORDINATES TO GEODETIC COORDINATES. INPUT TO PROGRAM-- SHIPS POSITIONS FROM EXTERNAL FIXES AND CORRESPONDING POSITIONS FROM IBECNAV' PROGRAM, AND BEACON POSITIONS IN LOCAL COORDINATES FROM 'SPANSIA'. AUTHOR-- S. KOCHANSKI, NSSNF. IPROGRAM DOCUMENTATION UNCLASSIFIED BUT DISTRIBUTION CONTROLLED BY NSSNF)

COMMANDING OFFICER

NAVAL STRATEGIC SYSTEMS NAVIGATION FACILITY

FLUSHING AND WASHINGTON AVENUES

BROOKLYN, NEW YORK 11251

GREAT CIRCLE DISTANCE BETWEEN TWO POINTS

\author{
LANGUAGE - FORTRAN
}

COMPUTER - CDC 3800

DETERMINES THE DistanCE In NAUTICAL MILES ALONG THE GREAT CIRCLE PATH BETWEEN TWO POINTS ON THE EARTH, AND THE INITIAL AND FINAL BEARINGS OF THAT PATH. THE EARTH IS ASSUMED SPHERICAL WITH ONE NAUTICAL MILE PER MINUTE OF ARC. DOCUMENTATION AVAILABLE-- NRL COMPUTER NOTE 32.

DAVID CHANG, CODE 8170

ACOUSTICS DIVISION

NAVAL RESEARCH LABORATORY, WASHINGTON, D. C. 20390

GREAT CIRCLE. PATHS FROM A POINT

LANGUAGE - FORTRAN
COMPUTER - CDC 3800

FROM A GREAT CIRCLE PATH SPECIFIED BY AN INITIAL POINT AND BEARING, THE PROGRAM GIVES THE LOCATIONS AND BEARINGS OF POINTS AT A GIVEN ARRAY OF DISTANCES IN NAUTICAL MILES ALONG THAT PATH. DOCUMENTATION -NRL COMPUTER NOTE 33.

DAVID CHANG, CODE 8170

ACOUSTICS DIVISION

NAVAL RESEARCH LABORATORY, WASHINGTON, D. C. 20390
LANGUAGE - FORTRAN IV-H COMPUTER - IBM $360 / 65$

(COPY ON FILE AT NODC)

CALCULATES THE LATITUDE AND LONGITUDE OF AN ASTRONOMIC OBSERVATION STATION, GIVEN MEASURED HORIZONTAL ANGLES BETWEEN STARS AND FIXED MARK ALONG WITH THE OBSERVATION TIMES. A SET OF OBSERVATION EQUATIONS IS SOLVED BY THE METHOD OF LEAST SQUARES TO OBTAIN CORRECTIONS TO ASSUMED VALUES OF LATITUDE, LONGITUDE, AND THE AZIMUTH OF THE REFERENCE MARK AS WELL AS PROBABLE ERRORS FOR THESE THREE QUANTITIES. THE ADJUSTMENT IS ITERATED FIVE TIMES OR UNTIL THE CORRECTIONS BECOME LESS THAN O.0O5 SECONDS, EITHER OF WHICH CAUSES A PROGRAM HALT. OUTPUT-- A TABLE OF INPUT INFORMATION AND A RECORD OF THE PROCESS OF REFINEMENT FOR EACH SET OF STATION DATA READ IN. STORAGE NEEDED-- APPROX. 37,500 BYTES FOR THE PROGRAM PLUS ITS SUBROUTINES. AUTHOR-- SPENCER ROEDDER. A PREVIOUS VERSION OF THIS PROGRAM WAS WRITTEN IN ALGOL FOR THE BURROUGHS 220, IN SINGLE PRECISION.

U.S. GEOLOGICAL SURVEY 
COMPUTER CENTER DIVISION

ATTN. RALPH EICHER, CHIEF

BRANCH OF SCIENTIFIC APPLICATIONS

WASHINGTON, D. C. 20242

ASTRONOMIC LATITUDE

LANGUAGE - FORTRAN

COMPUTER - (NOT GIVEN)

(COPY ON FILE AT NODC)

DETERMINATION OF FIRST ORDER ASTRONOMIC LATITUDE BY THE STERNECK METHOD. ALSO A PROGRAM USING THE METHOD OF IPOLARIS AND SOUTH STAR'. ALSO SUBROUTINES FOR THE BALDINI, THE GARFINKEL, AND THE U.S. COAST AND GEODETIC SURVEY REFRACTION MODELS. REF. A REPORT IINVESTIGATIONS IN DETERMINING ASTRONOMIC LATITUDES AND THEIR COMPUTER PROGRAMS' IR NO. 68$21(189$ P., APR 1968). AUTHOR-- LARRY BOURQUIN, CODE 8430, GEODESY. FURTHER INFORMATION MAY BE OBTAINED THROUGH DISSEMINATION DEPARTMENT CODE 44, OR THE AUTHOR.

NAVAL OCEANOGRAPHIC OFFICE

SUITLAND, MD. 20390

DEAD RECKONING NAVIGATION SYSTEM

LANGUAGE - FORTRAN

COMPUTER - IBM 1130

THIS SYSTEM IS USED AS A NAVIGATION AID TO COMPUTE AND PLOT THE CRUISE TRACK OF THE SHIP AND TO INDICATE THE LOCATIONS AT WHICH DATA WERE COLLECTED EN ROUTE. INPUT TO PROGRAM-- SHIPIS SPEED AND HEADING, WIND SPEED AND DIRECTION FROM PAPER TAPE (HEWLETT-PACKARD DATA ACQUISITION SYSTEMI, AND FIXES ON CARDS. OUTPUT-- PLOT OF CRUISE TRACK. DOCUMENTATION-- OPERATING INSTRUCTIONS ONLY.

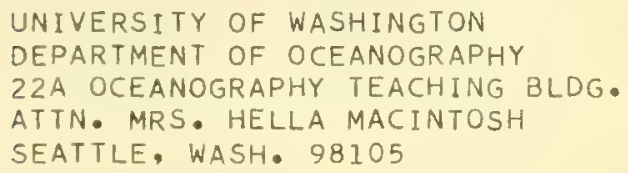

REDUCTION AND DISPLAY OF DATA ACQUIRED AT SEA

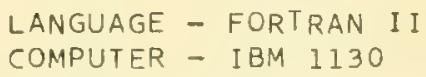

(COPY ON FILE AT NODC)

A SYSTEM OF PROGRAMS (NAVIGATION, GRAVITY, TOPOGRAPHY, MAGNETICS) FOR THE REDUCTION, STORAGE AND DISPLAY OF UNDERWAY DATA ACQUIRED AT SEA. THE COMPUTER INSTALLATION CONSISTS OF AN IBM 1130 AND INCLUDES RANDOM ACCESS DISK CARTRIDGES AND AN ON-LINE CALCOMP 30 IN. PLOTTER. A LARGE NUMBER OF THE PROGRAMS UTILIZE NAVIGATION POINTS TOGETHER WITH RAW DIGITIZED GEOPHYSICAL DATA PRESENTED AS A TIME SERIES, WHERE THE DIFFERENT DATA MAY BE READ AT UNEQUAL TIME INITERVALS. REF. TECH. REPORT NO. 1 (AUGUST 1969,348 P.) BY MANIK TALWANI.

\author{
LAMONT-DOHERTY GEOLOGICAL OBSERVATORY \\ COLUMBIA UNIVERSITY \\ PALISADES, NEW YORK 10964
}

\title{
SODANO INVERSE
}

( COPY ON FILE AT NODC) COMPUTES THE NORMAL SECTION LENGTH AND THE FORWARD AND REVERSE AZIMUTHS OF THE GEODESIC BETWEEN TWO POINTS FOR WHICH THE GEOGRAPHIC COORDINATES ARE KNOWN. THIS COMPUTATION IS USEFUL IN DETERMINING AZIMUTH AND DISTANCE BETWEEN TRIANGULATION STATIONS FOR WHICH GEOGRAPHIC POSITIONS HAVE BEEN DETERMINED BUT WHICH ARE NOT CONNECTED BY DIRECT OBSERVATION. OS NO. 4236. AUTHOR-- ANDREW CAMPBELL. MODIFIED BY C. E. PIERCE, MARCH 1967 . 
(COPY ON FILE AT NODC)

FINDS THE DISTANCE AND AZIMUTH BETWEEN TWO POINTS ON THE EARTHIS SUR-

FACE WHEN THE EARTH IS ASSUMED TO BE A SPHERE。 IF EITHER POLE IS USED FOR THE CENTER POINT, THE ANGLE GIVEN IS WITH RESPECT TO GRID NORTH. BY USE OF TRIGONOMETRIC IDENTITIES AND ABSOLUTE VALUE FUNCTIONS, THIS PROGRAM AVOIDS MANY OF THE COMPUTATIONAL PROBLEMS USUALLY FOUND IN DISTANCE COMPUTATIONS. O.S. NO. 55690. AUTHOR-- BARRY TURETT.

NAUTICAL CHART DIVISION, CODE 5600

NAVAL OCEANOGRAPHIC OFFICE

SUITLAND, MD. 20390

CIRCULAR CHARTING

LANGUAGE - FORTRAN

COMPUTER - IBM 7074

COMPUTES COORDINATES FOR CONCENTRIC CIRCLES AT SPECIFIED INTERVALS ALONG LATITUDE AND/OR LONGITUDE WITH A FIXED BROADCASTING STATION POSITION AS COMMON CENTER. COMPUTED DISTANCES ARE GEODESICS DASED ON ANY SPECIFIED GEOID. OS NO. 20132. AUTHOR-- CHARLES KIRKLAND.

COMPUTER DEPARTMENT, CODE 0831

NAVAL OCEANOGRAPHIC OFFICE

SUITLAND, MD. 20390

GEODETIC DATUM CONVERSION

LANGUAGE - FORTRAN

COMPUTER - IBM 7074

TRANSFORMS GEODETIC COORDINATES FROM ONE DATUM TO ANOTHER BY UTILIZING A GIVEN SHIFT (IN TERMS OF RECTANGULAR SPACE COORDINATES) BETWEEN THE ORIGINS OF TWO DATUMS AND APPLYING THIS SHIFT, TOGETHER WITH UIFFERENCES IN THE SPHEROIDAL PARAMETERS, IN FORMULAS DERIVED FOR THIS PURPOSE. OS NO. 55305. AUTHOR-- ROBERT M. WILLEMS.

NAVIGATIONAL SCIENCE DIV., CODE 5300

NAVAL OCEANOGRAPHIC OFFICE

SUITLAND, MD. 20390

\title{
GEODETIC DATUM REDUCTION
}

\author{
LANGUAGE - FORTRAN \\ COMPUTER - IBM 7074
}

REDUCES GEODETIC POSITIONS FROM ONE GEODETIC DATUM TO ANOTHER BY USE OF THE VENING MEINESZ EQUATIONS. THE PREFERRED DATUMS INVOLVED ARE EUROPEAN DATUM, NORTH AMERICAN DATUM AND TOKYO DATUM. OS NO. 55301. AUTHOR-- D.J. FINDLAY.

NAVIGATIONAL SCIENCE DIV., CODE 5300

NAVAL OCEANOGRAPHIC OFFICE

SUITLAND, MD. 20390

COMPUTE GEOGRAPHIC POSITIONS

LANGUAGE - SPS

COMPUTER - IBM 1620

(COPY ON FILE AT NODC)

USCGS PROGRAM NO. 15. COMPUTES GEOGRAPHIC POSITIONS, GIVEN STARTING

POSITION, AZIMUTH, AND LENGTH ON ANY ONE OF SIX SPHEROIDS. THREE TYPES OF COMPUTATIONS CAN BE OBTAINED-- SINGLE POSITIONS, A LOOP, OR A TRAVERSE. CONTROL IS BY JOB CARD. LENGTH INPUT MAY BE IN METERS, FEET, STATUTE OR NAUTICAL MILES, OR ELECTRONIC LANES.

ESSA, COAST AND GEODETIC SURVEY

WASHINGTON SCIENCE CENTER, BLDG. 2

ROCKVILLE, MD. 20852 
( COPY ON FILE AT NODC)

COMPUTES TABLES GIVING THE POINTS OF INTERSECTION OF LORAN C HYPERSOLAS WITH MERIDIANS ANDIOR PARALLELS OF THE EARTH SPHEROID. MICROSECOND VALUES ARE COMPUTED AT INTERVALS VARYING FROM $11 / 4$ MIN. TO 20 MIN. FOR ANY OR ALL OF FOUR POSSIBLE PAIRS OF STATIONS. PROGRAM CAN ALSO BE USED TO COMPUTE MICROSECOND VALUES AT GRID INTERSECTIONS. STORAGE 1OOK. PROGRAM CAN BE MODIFIED FOR USE ON IBM1620 OF 6OK CAPACITY.

ESSA, COAST AND GEODETIC SURVEY

WASHINGTON SCIENCE CENTER, BLDG. 2

ROCKVILLE, MD - 20852

GEODETIC POSITION COMPUTATION AND PLOT

$$
\begin{aligned}
\text { LANGUAGE - } & \text { FORTRAN } \\
\text { COMPUTER - } & \text { IBM } 7074 \text { W/ } \\
& \text { CALCOMP } 564
\end{aligned}
$$

(COPY ON FILE AT NODC)

COMPUTES GEODETIC POSITIONS AT DESIRED INTERVALS ALONG INCREMENTAL. OR MISCELLANEOUS AZIMUTHS. OPTION TO PLOT OR LIST. PLOT USES THE 'I.AMB. SUBROUTINE WITH TWO STANDARD PARALLELS. OS NO. 55321. AUTHOR-- MERLE L. NELSON. AN INFORMAL REPORT IR NO. 69-35 LISTS ADDITIONAL COMPUTER PROGRAMS AND DESCRIBES PROCEDURES FOR PRODUCTION OF SECONDARY PHASE CORRECTION CHARTS AND TABLES. THESE SUPPLEMENTARY PROGRAMS, WRITTEN BY MR EDWIN STEPHENSON AND MISS BARBARA GRAY, ARE IN 7074 AUTOCODER OR FORTRAN. INFORMATION MAY BE OBTAINED FROM DISSEMINATION CONTROI DEPT. CODE 44, OR THE AUTHOR.

NAVAL OCEANOGRAPHIC OFFICE

WASHINGTON, D.C. 20390

LORAN A AND C SKYWAVE

LANGUAGE - FORTRAN

COMPUTER - IBM 7074

COMPUTES POINTS FOR LORAN SKYWAVES WHICH ARE PRODUCED WHEN TRANSMITTED RADIO SIGNALS THAT TRAVEL UPWARD AND OUTWARD ENCOUNTER THE IONOSPHERE. (TWO DIFFERENT PROGRAM DECKS USED FOR LORAN A AND C SKYWAVES) AUTHOR-ROBERT VAN WIE. OS NO. 20158.

COMPUTER DEPARTMENT, CODE 083

NAVAL OCEANOGRAPHIC OFFICE

SUITLAND, MD. 20390

\section{LORAN COORDINATE COMPUTATION}

(COPY ON FILE AT NODC)

LANGUAGE - FORTRAN

COMPUTER - IBM 7074

COMPUTES CHARTING COORDINATES ALONG LINES OF LATITUDE OR LONGITUDE FOR LORAN CURVES AT SPECIFIED INTERVALS. INCLUDES SUBROUTINE BSLN, TO COMPUTE COORDINATES ALONG THE SASELINE AND BASELINE EXTENSIONS. RUNNING TIME-- 500-800 POINTS/MINUTE ON THE 7074. REF. IMR NO. N-1-64 (UNPUBLISHED MANUSCRIPT). OS NO. 20100. AUTHOR-- CHARLES KIRKI_AND.

COMPUTER DEPARTMENT, CODE 0831

NAVAL OCEANOGRAPHIC OFFICE

SUITLAND, MD. 20390

LORAN TO GEOGRAPHIC, GEOG. TO LORAN CONVERSIONS

LANGUAGE - FORTRAN

(COPY ON FILE AT NODC)

COMPUTER - IBM 7074

CONVERTS LORAN TIME OR PHASE DIFFERENCES TO GEOGRAPHIC COORUINATES BY NON-ITERATIVE METHOD (GEODESIC INVERSE DEVELOPED BY E.M. SODANO). THE CONVERSIONS ARE FOR LORAN A OR LORAN C OR FOR A MIXTURE OF THE TWO. REF. IMR NO. N-3-64 (UNPUBLISHED MANUSCRIPT). AUTHOR-- A.C. CAMPBELL. 
(COPY ON FILE AT NODC)

GIVEN THE GEOGRAPHICAL CO-ORDINATES OF TWO POINTS, SDANO CALCULATES THE GEODETIC DISTANCE AND AZIMUTHS BETWEEN THEM. BASED ON METHOD OF E.S. SODANO FOR A NON-ITERATIVE SOLUTION OF THE INVERSE AND DIRECT GEODETIC PROBLEMS. N.I.O. PROG. NO. -46 . AUTHOR-- M. FASHAM.

NATIONAL INSTITUTE OF OCEANOGRAPHY WORMLEY, GODALMING, SURREY ENGLAND

HNV 1 (LORAN/DECCA FILE INITIALISATION)

(COPY ON FILE AT NODC) COMPUTER - IBM 1800 SYS

GIVEN INPUT DATA ON A MASTER-SLAVE PAIR, HNVI CALCULATES CERTAIN GEODETIC VALUES AND STORES THEN ON TAPE FILE FOR LATER USE BY PROGRAM HNAV. N.I.O. PROGRAM NO. 164. AUTHOR-- M. FASHAM.

NATIONAL INSTITUTE OF OCEANOGRAPHY WORMLEY, GODALMING, SURREY ENGLAND

HNAV (LORAN/DECCA COORDINATES CALCULATION)

LANGUAGE - FORTRAN IV COMPUTER - IBM 1800 SYS

(COPY ON FILE AT NODC)

GIVEN A DECCA, LORAN-A OR LORAN-C FIX, CALCULATES THE LATITUDE AND LONGITUDE. THE METHOD FOR A HYPERBOLIC SYSTEM WITH SEPARATE MASTER IS USED FOR ALL CASES. THE CONSTANTS FOR THE HYPERBOLOIDS ARE CALCUI_ATED IN METRES FOR BOTH LORAN AND DECCA THUS ALLOWING A FIX TO BE CAILCULATED IF ONE LORAN READING AND ONE DECCA READING ARE KNOWN. N.I.O. PROGRAM NO. 165. USES 'SDANO' AND OTHER SUBROUTINES. AUTHOR-- M. FASHAM

NATIONAL INSTITUTE OF OCEANOGRAPHY WORMLEY, GODALMING, SURREY ENGLAND

PROVIDES A WIDE VARIETY OF MAP PROJECTIONS AND GRIDS TO FACILITATE THE DISPLAY OF GEOGRAPHICAL DATA. THE PROGRAM HAS BEEN WRITTEN IN AS MODULAR A FORM AS POSSIBLE TO ALLOW FOR EASE OF INSERTION OR DELETION OF ROUTINES. PRESENTLY UNDER DEVELOPMENT BY JOHN O. WARD, THIRTEEN MAP PROJECTIONS ARE NOW AVAILABLE, AND IN THE NEAR FUTURE SIX MORE WIIL BE ADDED.

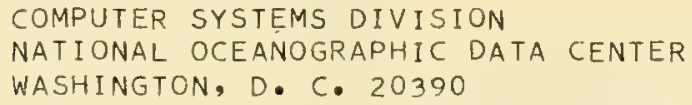

INDIVIDUAL POINT GENERATOR FOR MAP PROJECTIONS

LANGUAGE - FORTRAN II

COMPUTER - IBM 7074

(COPY ON FILE AT NODC)

CONVERTS GEOGRAPHIC POSITIONS TO DISCRETE POINTS IN RECTANGULAR COORDINATES ON THE FOLLOWING PROJECTIONS-- MERCATOR, TRANSVERSE MERCATOR, GNOMONIC, POLAR STEREOGRAPHIC, AZIMUTHAL EQUIDISTANT, LANBERT CONFORMAL (WITH TWO OR ONE STANDARD PARALLELS), LAMBERT AZIMUTHAL EQUAL. AREA POLAR, LAMBERT EQUAL AREA CYLINDRICAL, MILLER, ALBERS EQUAL AREA CONIC, RECTIFIED SKEW ORTHOMORPHIC, AND OBLIQUE MERCATOR. CARTOGRAPHIC 
DATA MAY BE PRODUCED IN EITHER GRAPHIC OR TABULAR FORM. OS NU. 55646 IMAIN PROGRAM. EACH OF THE 13 PROJECTION SUBROUTINES HAS ITS OWN OPEN SHOP NUMBER 1. AUTHORS-- RONALD BOLTON, LOUIS ROWEN, GREGORY VEGA. REF. INFORMAL REPORT IR NO. 69-23, MAR 1969 'COMPUTER PROGRAMS AND SUBROUTINES FOR AUTOMATED CARTOGRAPHY', BY J. PARRINELLO, NAUTICAI. CHART DIVISION. FURTHER INFORMATION MAY BE OBTAINED THROUGH DISSEMINATION DEPARTMENT CODE 44, OR THE AUTHORS.

NAVAL OCEANOGRAPHIC OFFICE WASHINGTON, D.C. 20390

INDIVIDUAL POINT GENERATOR FOR DISTANCE AND AZIMUTH COMPUTATIONS

LANGUAGE - FORTRAN I I

COMPUTER - IBM 7074

USES THE GEODETIC LATITUDE AND LONGITUDE OF TWO POINTS TO COMPUTE THE DISTANCE AND AZIMUTH FROM ONE POINT TO THE OTHER . RESULTS WILL BE IN TABULAR FORM WITH THE DISTANCE IN METERS AND THE AZIMUTH AND BACK AZIMUTH IN DEGREES, MINUTES AND SECONDS. O.S. NO. 656I6, BY R.M. BOLTON.

NAUTICAL CHART DIVISION, CODE 5620

U.S. NAVAL OCEANOGRAPHIC OFFICE

WASHINGTON D. C. 20390

PARAMETRIC MAP

LANGUAGE - FORTRAN 1 I

COMPUTER - IBM 7074

GENERATES ANY HYPERBOLIC NAVIGATION SYSTEM BY USING PARAMETRIC EQUATIONS. GENERATES PLOTTING COORDINATES FOR LORAN A, LORAN C, OMEGA AND DECCA CHARTS. WILL PROCESS ALL LATTICE LINES THAT FALL. WITHIN A SPECIFIED GEOGRAPHIC AREA. CAN BE DISPLAYED ON ANY OF THE FOLLOWING MAP PROJECTIONS-- MERCATOR, TRANSVERSE MERCATOR, LAMBERT CONFORMAL CONIC, OBLIQUE MERCATOR, POLYCONIC. O.S. NO. 530I2. AUTHORS-- R.A. BOLTON, R.M. BOLTON.

NAUTICAL CHART DIVISION, CODE 5620

U.S. NAVAL OCEANOGRAPHIC OFFICE

WASHINGTON D. C. 20390

DECCA HI-FIX

LANGUAGE - FORTRAN

COMPUTER - PDP-5, $8 \mathrm{~S}$

GENERAL PURPOSE PROGRAM FOR CONVERSION OF HYPERBOLIC COORDINATES TO $X-Y$ COORDINATE SYSTEMS. TYPE GEOGRAPHIC COORDINATES OF MASTER AND SLAVE STATIONS - PAPER TAPE OR KEYBOARD INPUT FOR LANE COUNTS, OUTPUT ON ASR-33 TELEPRINTER. WRITTEN FOR THE U.S. COAST GUARD BY LT. R.M. O.HAGAN (RET.). COPY OF PROGRAM WAS DEPOSITED WITH DECUS IDIGITAI_EQUIPMENT CORP. USERS SOCIETYI.

DIGITAL EQUIPMENT CORPORATION
MAYNARD, MASSACHUSETTS 01754

HYPERMAP

LANGUAGE - FORTRAN

COMPUTER - (NOT GIVEN)

(COPY ON FILE AT NODC)

A SERIES OF PROGRAMS FOR DRAWING MAPS AND PLOTTING DATA ON THEM. THE PROGRAM OPERATES UNDER A SIMPLE COMMAND LANGUAGE WHICH ENABLES THE USER TO REFER TO HIS DATA AND THE MAP DATA BY NAME. THERE ARE ELEVEN PROJECTION OPTIONS AVAILABLE IN THE BASIC TRANSFORMATION SUBROUTINE. A MORE ADVANCED PACKAGE IWITH SEVERAL PROJECTIONS TAKING THE LLLIPTICITY OF THE EARTH INTO ACCOUNT) IS UNDER DEVELOPMENT. AUTHOR-- DR ROBERT L PARKER, UNIV. OF CALIFORNIA AT SAN DIEGO.

PROF. JOHN D. MUDIE

SCRIPPS INSTITUTION OF OCEANOGRAPHY

LA JOLLA, CALIF. 92037 


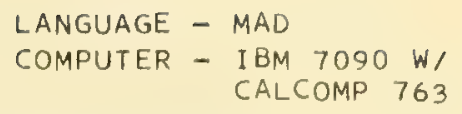

FINITE MAP PROJECTION DISTORTIONS

LANGUAGE - MAD

COMPUTER - IBM 7090

(COPY ON FILE AT NODC)

PROGRAMS AND SUBROUTINES TO ESTIMATE THE ERRORS INTRODUCED BY THE SUBSTITUTION OF MAP PROJECTION COORDINATES FOR SPHERICAL COORDINATES. STATISTICAL COMPUTATIONS OF FINITE DISTORTION ARE RELATED TO TISSOTIS INDICATRIX AS A GENERAL CONTRIBUTION TO THE ANALYSIS OF MAP PROJECTIONS. REF. TECHNICAL REPORT NO. 3 'GEOGRAPHICAL COORDINATE COMPUTATIONS PART II', BY $W$. R. TOBLER, DEPT. OF GEOGRAPHY.

THE UNIVERSITY OF MICHIGAN

ANN ARBOR, MICHIGAN 
( COPY ON FILE AT NODC)

SUBPROGRAM CALCULATES SATURATION VAPOUR PRESSURE OVER WATER - INPUT IS TEMPERATURE IN DEGR. $K$. USES AN EQUATION FROM SMITHSONIAN TABLES PAGE 350. THE FUNCTION CONVERTS THE LOG OUTPUT OF THIS EQUATION TO ACTUAL PRESSURE IN MILLIBARS. N.I.0. PROG. NO. -24. AUTHOR-- R. HOWARTH.

NATIONAL INSTITUTE OF OCEANOGRAPHY WORMLEY, GODALMING, SURREY

ENGLAND

AIR-SEA

LANGUAGE - FORTRAN
COMPUTER - IBM 7074

DETERMINES THE RELATION BETWEEN THE 500 MB. WIND FIELD AND OCEAN SURFACE CONDITIONS (WAVES), THROUGH THE USE OF STATISTICAL METHODS. O.S. PROGRAM NO. 53464 , BY W.H. GEMMILL.

OCEANOGRAPHIC PREDICTION DIV., CODE 3400

NAVAL OCEANOGRAPHIC OFFICE

SUITLAND, MD. 20390

CLOUD COVER AND DAILY SEA TEMPERATURE

LANGUAGE - FORTRAN

COMPUTER - IBM 7074

DIVIDES CLOUD COVER INTO THREE GROUPS AND COMPUTES MEAN TEMPERATURE BY HOUR OF DAY AND BY DAY FOR EACH DEPTH. OS NO. 53414. AUTHOR-- D. B. NIX.

OCEANOGRAPHIC PREDICTION DIV., CODE 3400 NAVAL OCEANOGRAPHIC OFFICE SUITLAND, MD. 20390

LAYER DEPTH PLOT

LANGUAGE - FORTRAN COMPUTER - IBM 7074

COMPUTES AND PLOTS LAYER DEPTH, ON A SYNOPTIC BASIS, FROM VARIOUS DEFINITIONS. OS NO. 53453. AUTHOR-- D.B. NIX.

OCEANOGRAPHIC PREDICTION DIV., CODE 3400 NAVAL OCEANOGRAPHIC OFFICE

SUITLAND, MD. 20390

PREDICTION OF VERTICAL TEMPERATURE CHANGE

LANGUAGE - FORTRAN COMPUTER - IBM 7074

( COPY ON FILE AT NODC)

A TECHNIQUE BASED PRIMARILY ON HEAT BUDGET AND WIND MIXING CALCULATIONS HAS BEEN DEVELOPED FOR PREDICTING THE VERTICAL THERMAL STRUCTURE OF THE OCEAN. THE TECHNIQUE ESSENTIALLY MODIFIES THE INITIAL THERMAL STRUCTURE THROUGH INCIDENT SOLAR RADIATION, BACK RADIATION, SENSIBLE AND EVAPORATIVE HEAT EXCHANGE, CONVECTIVE HEAT TRANSFER IN THE WATER MASS, AND WIND MIXING. PREDICTIONS ARE MADE AT 6-HOUR INTERVALS UNTIL $1200 Z$ ON THE DATE OF FORECAST. THE PREDICTED BT IS PRINTED OUT, ALSO CAN BE PLOTTED WITH A BENSON-LEHNER MONEL J PLOTTER. AUTHORS-- W.H. GEMMILL AND D.B. NIX. REF. IMR NO. 0-42-65 (UNPUBLISHED MANUSCRIPT). 
SEE ALSO IMR NO. 0-45-65 BY B. THOMPSON, AND IMR NO. 0-13-66 BY BAR-

NETT AND AMSTUTZ. PROGRAM LISTINGS SEPARATE FROM MANUSCRIPTS.

OCEANOGRAPHIC PREDICTION DIV., CODE 3400

NAVAL OCEANOGRAPHIC OFFICE

SUITLAND, MD. 20390

TWO-DIMENSIONAL POWER SPECTRUM FOR SWOP II

LANGUAGE - FORTRAN

COMPUTER - IBM 7074

DETERMINATION OF SPECTRUM ASSOCIATED WITH THE SPATIAL DISTRIBUTION OF ENERGY AS OBTAINED FROM AN INSTANTANEOUS PICTURE OF THE OCEAN TAKEN FROM AIRCRAFT (SWOP II). OS NO. 53484. AUTHOR-- C.M. WINGER.

OCEANOGRAPHIC PREDICTION DIV., CODE 3400

NAVAL OCEANOGRAPHIC OFFICE

SUITLAND, MD. 20390

WIND STRESS

LANGUAGE - FORTRAN

COMPUTER - IBM 7074

DETERMINES WIND STRESS ON THE OCEAN SURFACE. OS NO. 53462 . AUTHOR-W.H. GEMMILL.

OCEANOGRAPHIC PREDICTION DIV., CODE 3400

NAVAL OCEANOGRAPHIC OFFICE

SUITLAND, MD. 20390

$\begin{array}{ll}\text { TRANSPORT COMPUTATIONS FROM ATMOSPHERIC PRESSURE LANGUAGE - FORTRAN II } & \text { AND IV } \\ & \text { COMPUTER - IBM I620, } \\ & \text { IBM } 7040 \text { AND } \\ & \text { IBM } 1130\end{array}$

(COPY ON FILE AT NODC - FORTRAN II FOR 1620 ONLY)

COMPUTES, ACCORDING TO A SYSTEM OF ANALYSIS DESIGNED BY DR. N.P. FOFONOFF, THE STEADY STATE MASS TRANSPORT IN THE OCEAN FROM ATMOSPHERIC PRESSURE DATA, MERIDIONAL AND ZONAL COMPONENTS OF EKMAN TRANSPORT, TOTAL MERIDIONAL TRANSPORT, INTEGRATED TRANSPORT AND INTEGRATLD GEOSTROPHIC TRANSPORT. INPUT ARE SEA LEVEL PRESSURE CARDS FROM THE EXTENDED FORECAST DIV. OF THE U.S. WEATHER BUREAU. OUTPUT ARE MEAN MONTHLY VALUES FOR THE SPECIFIED GRID OF ALTERNATE 5 DEGREES OF LATITUDE AND LONGITUDE IN THE NORTHERN HEMISPHERE. FORTRAN I I PROGRAM IS PUBLISHED IN FISHERIES RESEARCH BOARD OF CANADA, MS. SERIES IOCEAN. AND LIMNOL.) NO. 163, 1963 BY DR. CHARLOTTE FROESE. FORTRAN IV PROGRAM HELD BY STATISTICAL SERVICES, FISHERIES RESEARCH BOARD OF CANADA, BIOLOGICAL STATION, NANAIMO, B. C., CANADA.

OCEANOGRAPHER - IN-CHARGE

PACIFIC OCEANOGRAPHIC GROUP

BIOLOGICAL STATION

NANAIMO, B. C., CANADA

SYNOPTIC ANALYSIS AND FORECASTING OF

LANGUAGE - MACHINE

SURFACE CURRENTS

$$
\begin{aligned}
\text { COMPUTER - } & \text { CDC } 1604 \text { AND } \\
& \text { CDC } 3200
\end{aligned}
$$

INPUT IS SURFACE WIND ANALYSIS/FORECAST, SEA SURFACE TEMPERATURE ANALYSIS/FORECAST, 600 FEET TEMPERATURE ANALYSIS AND SOME CLIMATOLOGY. OUTPUT IS SURFACE CURRENT TRANSPORT IN NAUTICAL MILES PER 24 HOURS, CURRENT DIRECTION AND STREAM FUNCTION. REF. FNWF TECHNICAL NOTE NO. 9 AND HUBERT (1965). DIRECT REQUESTS FOR INFORMATION TO--

COMMANDING OFFI CER

FLEET NUMERICAL WEATHER CENTRAL

MONTEREY, CALIFORNIA 93940 
COMPUTES CURRENTS FROM STANDARD WIND OBSERVATIONS.

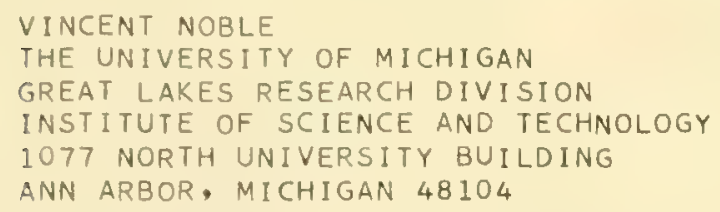

RADIATION TEMPERATURE OF SEA SURFACE

(COPY ON FILE AT NODC)

EVALUATES THREE EMPIRICAL EQUATIONS, DEVELOPED BY REGRESSION METHODS, TO OBTAIN AN ESTIMATE OF THE DIFFERENCE BETWEEN SKIN AND BUCKET TEMPERATURES FROM STANDARD WEATHER OBSERVATIONS MADE AT SEA. THESIS BY ROBERT D. BOUDREAU, REF. NO. 65-15T (1965,79 P).

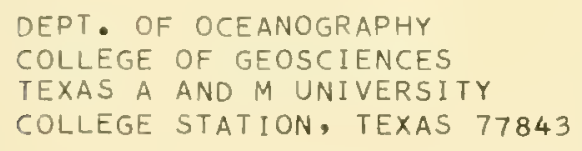

SYNOPTIC ANALYSIS AND FORECASTING OF POTENTIAL MIXED LAYER DEPTH

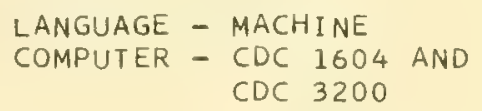

INPUT TO PROGRAM-- CLIMATOLOGY, SYNOPTIC WAVE HEIGHT ANALYSIS/FORECAST, SEA SURFACE TEMPERATURE ANALYSIS, 600 FEET TEMPERATURE ANALYSIS/ FORECAST, AND BT OBSERVATIONS. OUTPUT IS MIXED LAYER DEPTH IN FEET AT GRID POINTS $163 \times 63$ FIELD), TENDENCY OF THERMOCLINE INEXT 24 HOURS, MAGNITUDE, AND SHORT TERM FLUCTUATIONS OF THE THERMOCLINE. REF-- SEE FNWF TECHNICAL NOTE NO. 10 AND/OR NO. 21. DIRECT INQUIRIES TO--

COMMANDING OFFICER

FLEET NUMERICAL WEATHER CENTRAL

MONTEREY, CALIFORNIA 93940

\section{**** CURRENTS AND TRANSFER PROCESSES}

SURFACE CURRENT SUMMARY

LANGUAGE - AUTOCODER

COMPUTER - IBM 7074

( COPY ON FILE AT NODC)

THE RESULTANT CURRENT SPEED AND RESULTANT CURRENT DIRECTIONS ARE COMPUTED BY MARSDEN SQUARE, 1-DEG. OR 5-DEG. SQUARE AND MONTH FROM H 1-9, NETHERLANDS 193 OR JAPANESE 118 DATA. OS NO. 52252. AUTHOR-- MAXINE JACKSON.

COMPUTER SYSTEMS DIVISION

NATIONAL OCEANOGRAPHIC DATA CENTER

WASHINGTON, D. C. 20390

MODIFIED SURFACE CURRENTS

LANGUAGE - AUTOCODER

COMPUTER - IBM 7074

(COPY ON FILE AT NODC)

MODIFIES M.H. JACKSON'S PROGRAM TO PROVIDE THE SAME INFORMATION ON A

FILE REPRESENT ING THE H $1-9,118$ (JAPANESE), 193 (NETHERLANDS) FIIES

COMBINED. AUTHOR-- C.S. CALDWELL.. OS NO. 20156.

COMPUTER DEPARTMENT, CODE 083 
NAVAL OCEANOGRAPHIC OFFICE

SUITLAND, MD. 20390

STATISTICAL SURFACE CURRENT ROSE

LANGUAGE - AUTOCODER

COMPUTER - IBM 7074

CALCULATES FREQUENCIES OF A NORMAL DISTRIBUTION, POPULATING THE DIRECTIOM-SPEED GROUPS OF A STANDARD ROSE FORMAT, WHICH BEST FITS THE ACTUAL DATA SURFACE IREF. SP-64 - A STATISTICAL ROSE PROGRAM-, BY W. YERGEN I. OS NO. 53301. AUTHOR-- W. YERGEN.

OCEANOGRAPHIC ANALYSIS DIV., CODE 3300

NAVAL OCEANOGRAPHIC OFFICE

SUITLAND, MD. 20390

COMPUTE ADVECTION

LANGUAGE - FORTRAN

COMPUTER - IBM 1401

COMPUTES HORIZONTAL ADVECTION FROM AN INITIAL POINT IN THE WATER COLUMN FROM EQUATIONS DESCRIBED BY A. FISHER, IM NO. 66-9 (INFORMAI. MANUSCRIPT). FROM KNOWN INPUTS OF DENSITY, CURRENT VELOCITIES, AND TEMPERATURE GRADIENTS, ADVECTION IS COMPUTED FROM AN INITIAL POINT OVER A GIVEN DISTANCE, ASSUMING NO VERTICAL HEAT LOSS. HORIZONTAL COMPONENTS IN THE $X, Y$ PLANE ARE COMPUTED AND A RESULTANT VECTOR IS DETERMINED. OS NO. 53490. AUTHOR-- R.K. FRANKLIN.

OCEANOGRAPHIC PREDICTION DIV., CODE 3400

NAVAL OCEANOGRAPHIC OFFICE

SUITLAND, MD. 20390

GVPA , VPA

LANGUAGE - FORTRAN IV

COMPUTER - IBM $360 / 65$

CALCULATES VELOCITIES AND TRANSPORTS FOR AS MANY AS $5 O$ SUCCESSIVE STATION PAIRS. USES AS INPUT INTERPOLATED DATA ON CARDS FROM PROGRAM 'DYNAM!, WHICH CALCULATES DYNAMIC HEIGHTS AT STANDARD DEPTHS.

BUREAU OF COMMERCIAL FISHERIES

P. O. BOX 3830

HONOLULU, HAWAII 96812

\author{
STANDARD-VECTOR DEVIATION ROSE FOR CURRENT DATA LANGUAGE - FORTRAN
}

( COPY ON FILE AT NODC)

CALCULATES THE FOLLOWING PARAMETERS FOR A TWO DIMENSIONAL NORMAL_ELLIPTICAL DISTRIBUTED CURRENT FIELD - MEAN SPEED, COMPONENTS OF THE VECTOR MEAN, COMPONENTS OF THE STANDARD-VECTOR DEVIATION ALONG THE PRINCIPAL AXES, AND THE INCLINATION OF THE MAJOR AXIS. PROGRAM HAS BEEN IN USE PRINCIPALLY AS AN AID IN AIR-SEA RESCUE OPERATIONS. INPUT IS CURRENT DATA WHICH HAS BEEN TABULATED IN SPECIFIED SPEED-INTERVAL CLASSES FOR EIGHT COMPASS POINTS. REF. IMR 0-22-65 (UNPUBLISHED MANUS(RIPT). AUTHOR-- DONALD A. BURNS, CODE 7200.

OCEANOGRAPHIC ANALYSIS DIV., CODE 3300

NAVAL OCEANOGRAPHIC OFFICE

SUITLAND, MD. 20390

GULF STREAM PATH

LANGUAGE - FORTRAN

COMPUTER - IBM 7074

PREDICTS THE PATH OF THE GULF STREAM BY MEANS OF 1 I A SINE GENERATED FUNCTION, 2) THE CONSERVATION OF POTENTIAL VORTICITY, AND 3 ) HARMONIC ANALYSIS. AUTHOR-- W.H. GEMMILL.

OCEANOGRAPHIC PREDICTION DIV , CODE 3430

NAVAL OCEANOGRAPHIC OFFICE 
COMPUTATION OF VELOCITY AND HORIZONTAL MIXING EDDY COEFFICIENTS ALONG ISENTROPIC SURFACES. AUTHOR-- A.D. KIRWAN.

TEXAS A AND M UNIVERSITY

COLLEGE OF GEOSCIENCES

DEPARTMENT OF OCEANOGRAPHY

COLLEGE STATION, TEXAS 77843

\section{SALINITY DISTRIBUTION IN ONE-DIMENSIONAL ESTUARY \\ LANGUAGE - FORTRAN \\ COMPUTER - (NOT GIVEN)}

\section{(COPY ON FILE AT NODC)}

A MODEL IS CONSTRUCTED FOR AN ESTUARY TO PREDICT THE SALINITY DISTRIBUTION FOR A GIVEN FRESH WATER INFLOW, WITH APPLICATION TO THE UPPER CHESAPEAKE BAY AND THE SUSQUEHANAA RIVER. BASED ON A SALT CONTINUITY EQUATION IN WHICH THE SEAWARD SALT ADVECTION IS BALANCED BY TURBUILENT DIFFUSION TOWARD THE HEAD OF THE BAY. IN FINAL FORM, IT IS A LINEAR, SECOND-ORDER, AND PARABOLIC PARTIAL DIFFERENTIAL EQUATION WITH VARIABLE COEFFICIENTS WHICH ARE FUNCTIONS OF BOTH SPACE AND TIME. REF. 697, TECH. REPORT 54 (MAY 1969,70P.) BY WILLIAM BOICOURT.

CHESAPEAKE BAY INSTITUTE

THE JOHNS HOPKINS UNIVERSITY

BALTIMORE, MD. 21218

PROCESSING OF OCEANOGRAPHIC OBSERVATIONS

LANGUAGE - FORTRAN II
COMPUTER - IBM 1620 I

( COPY ON FILE AT NODC)

A NUMBER OF PROGRAMS AND SUBROUTINES FOR PROCESSING 'MICHELSENS CON-

TAINER' DATA (AUTOMATIC CURRENT AND TEMPERATURE MEASUREMENTS), FOR PROCESSING EKMAN CURRENT METER DATA, AND FOR HARMONIC ANALYSIS AND POWER SPECTRUM ANALYSIS. REF. TECHNICAL REPORT NO. 37, NATO SUBCOMMITEE ON OCEANOGRAPHIC RESEARCH (105 P., FEB 1967). AUTHOR-- DR. H.E. SWEERS (OF THE CANADIAN OCEANOGRAPHIC DATA CENTRE).

GEOPHYSICAL INST ITUTE

UNIVERSITY OF BERGEN

BERGEN, NORWAY

\author{
LANGUAGE - AUTOCODER \\ COMPUTER - IBM 7074
}

(COPY ON FILE AT NODC)

COMPUTES THE FOLLOWING FROM BOTTLE RECOVERY INFORMATION-- BEARING, NAUTICAL MILES DRIFTED, NUMBER OF DAYS ADRIFT, AND SPEED IN NAUTICAL MILES PER DAY . COMPUTES MARSDEN AND 1/4-DEGREE SQUARES OF RELEASE. OUTPUT ON MAGNETIC TAPE. AUTHOR-- JUDY YAVNER. USED WITH A TAPE TO PRINT/CARD EDITING AND SELECTION PROGRAM. AUTHOR-- JOHN JENSON.

COMPUTER SYSTEMS DIVISION, CODE 2400

NATIONAL OCEANOGRAPHIC DATA CENTER

WASHINGTON, D.C. 20390

LATERAL RELATIVE DISTRIBUTION OF MATERIAL FROM

A CONTINUOUS SOURCE IN A CONSTANT CURRENT
LANGUAGE - FORTRAN II
COMPUTER - IBM 7094

PREDICTS THE RATIO OF THE CONCENTRATION OF A CONTAMINANT TO ITS CENTER LINE VALUE AS A FUNCTION OF LONGITUDINAL AND TRANSVERSE DISTANCE FROM THE SOURCE DUE TO HORIZONTAL ADVECTION AND DIFFUSION WHEN DISCHARGED AS A VERTICAL LINE SOURCE OF UNIT DEPTH AND UNIT RATE OF DISCHARGE IIN AN UNBOUNDED MEDIUM. INPUT ARE THE VELOCITY (A CONSTAF:T), THE LONGITUDINAL AND TRANSVERSE COORDINATES, AND THE DIFFUSION VELOCITY, I.E., 
THE SPREADING COEFFICIENT, A MEASURE OF THE HORIZONTAL DIFFUSION. THE OKUBO-PRITCHARD MODEL FOR AN INSTANTANEOUS RELEASE IS USED FOR THE MODEL. AUTHORS-- H.E. WALTERS AND H.H. CARTER.

HARVEY E. WALTERS

CHESAPEAKE BAY INSTITUTE

THE JOHNS HOPKINS UNIVERSITY

CHARLES AND 34 TH ST.

BALTIMORE, MD. 21218

CONTINUOUS LINE SOURCE (REFLECTED)

LANGUAGE - FORTRAN II

COMPUTER - IBM 7094

PREDICTS THE HORIZONTAL STEADY STATE DISTRIBUTION OF A CONTAMINANT DUE TO HORIZONTAL ADVECTION AND DIFFUSION WHEN DISCHARGED AS A VERTICAL PLANE SOURCE OF UNIT DEPTH AND UNIT RATE OF DISCHARGE AND LOCATED PERPENDICULAR TO A BOUNDARY. THE VELOCITY IS ASSUMED TO BE CONSTANT. THE OKUBO-PRITCHARD MODEL FOR AN INSTANTANEOUS RELEASE IS USED. IT IS INTEGRATED LATERALLY TO TRANSFORM A VERTICAL LINE SOURCE SOLUTION TO A SOLUTION FOR A VERTICAL PLANE SOURCE AND IS TOTALLY RELECTED AT THE BOUNDARY TO QUANTITATE THE BOUNDARY EFFECT. AUTHORS-- H.E. WALTERS AND H.H. CARTER.

HARVEY E. WALTERS

CHESAPEAKE BAY INSTITUTE

THE JOHNS HOPKINS UNIVERSITY

CHARLES AND 34TH ST.

BALTIMORE, MD. 21218

CONTINUOUS SOURCE IN TIDAL ESTUARY PER

LANGUAGE - FORTRAN II

UNIT DEPTH AND UNIT RATE OF RELEASE

COMPUTER - IBM 7094

PREDICTS THE CENTERLINE LONGITUDINAL DISTRIBUTION OF A CONTAMINANT AS A FUNCTION OF PUMPING TIME, DUE TO HORIZONTAL ADVECTION AND DIFFUSION WHEN DISCHARGED AS A VERTICAL LINE SOURCE OF UNIT DEPTH AT A CONSTANT RATE IN A TIDAL ESTUARY. INPUT ARE THE MAXIMUM TIDAL VELOCITY, THE NON-TIDAL VELOCITY, THE DIFFUSION VELOCITY I.E. SPREADING COEFFICIENT, A MEASURE OF HORIZONTAL DIFFUSION, PUMPING TIME I.E. TIME SINCE SOURCE WAS INITIATED, AND THE LONGITUDINAL DISTANCE FROM THE SOURCE. STORAGE NECESSARY - 15000 WORDS (CAN BE EASILY CHANGED TO 7000 WORDS). AUTHORS - H.E. WALTERS AND H.H. CARTER.

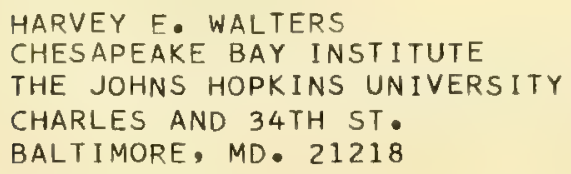

CONTINUOUS SOURCE IN TIDAL ESTUARY PER UNIT DEPTH AND UNIT RATE OF RELEASE, WITH COOLING TERM

LANGUAGE - FORTRAN I I COMPUTER - IBM 7094

PREDICTS THE CENTERLINE LONGITUDINAL DISTRIBUTION OF HEAT AS A FUNCTION OF PUMPING TIME DUE TO HORIZONTAL ADVECTION, DIFFUSION, AND ATMOSPHERIC COOLING WHEN DISCHARGED AS A VERTICAL LINE SOURCE AT A CONSTANT RATE IN A TIDAL ESTUARY. THE OKUBO-PRITCHARD MODEL FOR AN INSTANTANEOUS RELEASE IS USED FOR THE MODEL. IT IS FURTHER ASSUMED THAT EACH INF INITESIMAL RELEASE COOLS EXPONENTIALLY WITH TIME. THE RATE COEFFICIENT IS CALLED THE COOLING COEFFICIENT. CORE STORAGE NECESSARY-15000 WORDS (CAN BE RUN USING 7000 WORDS). AUTHORS-- H.E. WALTERS AND H.H. CARTER.

HARVEY E. WALTERS

CHESAPEAKE BAY INSTITUTE

THE JOHNS HOPKINS UNIVERSITY

CHARLES AND $34 \mathrm{TH}$ ST.

BALTIMORE, MD. 21218 
PROGRAM WITH SUBROUTINES AS ESTIMATOR FOR DERIVING POSITION AND EULER ATTITUDE (PITCH AND ROLL) ANGLES SO THAT PRECISE CURRENT METER DYNAMICS CAN BE OBTAINED. APPLIED TO A REAL CASE PROBLEM FOR WHICH SIMULATION RESULTS ARE DISCUSSED. THESIS BY MICHEL FROIDEVAUX (JAN 1968 ) - APPLICATION OF STATISTICAL ESTIMATION TO THE DETERMINATION OF OCEAN CURRENT METER DYNAMICS .

INSTRUMENTATION LABORATORY

MASSACHUSETTS INSTITUTE OF TECHNOLOGY

CAMBRIDGE, MASSACHUSETTS 02139

CURRENT METER TURBULENCE

LANGUAGE - FORTRAN

COMPUTER - IBM 7074

GIVES AN INDICATION OF TURBULENCE IN THE OCEAN BY COMPUTING MEASURES OF THE DEVIATIONS FROM MEANS OVER VARIOUS LENGTHS OF TIME. OS NO. 57202. AUTHOR-- ROBERT R. GLEASON.

EXPLORATORY OCEANOGRAPHY DIV. , CODE 7200

NAVAL OCEANOGRAPHIC OFFICE

SUITLAND, MD. 20390

FLOW METER PLOIS

LANGUAGE - FORTRAN IV

COMPUTER - IBM $360 / 65$, CALCOMP

(COPY ON FILE AT NODC)

DETERMINES FLOW METER PERFORMANCE AND PLOTS NUMBER OF REVOLUTIONS VS.

TIME. OUTPUT GIVES THE COSFFICIENT OF CORRELATION AND STANDARD DEVIATION, AND THE REGRESSION LINE AND 1.96 STANDARD DEVIATIONS ARE MARKED OFF ON THE PLOT. CORE STORAGE USED-- 3IK BYTES (WITH PLOT ROUTINES). AUTHOR-- MARILYNN BORKOWSKI.

BUREAU OF COMMERCIAL FISHERIES

TROPICAL ATLANTIC BIOLOGICAL LABORATORY

75 VIRGINIA BEACH DRIVE

MIAMI, FLORIDA 33149

FILM DATA PROCESSING

LANGUAGE - FORTRAN-60

COMPUTER - CDC 1604

ACCEPTS RICHAROSON'S CURRENT DATA FROM A BINARY TAPE SUPPLIED BY INFORMATION INTERNATIONAL, INC. NORTH-SOUTH AND EAST-WEST VELOCITY COMPONENTS ARE COMPUTED FROM THE COMPASS, VANE, RO AND RIO COUNTERS, AND ALL INFORMATION MAY BE PRINTED EVERY TIME SLICE. A HISTOGRAM OF THESE COMPONENTS IS PRINTED AT THE END OF EACH FILM. FURTHERMORE, AN ENVELOPE OF THE CURRENT ANGLES AND CURRENT SPEEDS IS SHOWN AT 2-HOUR INTERVALS. FINALLY, 6-HOUR MEANS AND STANDARD DEVIATIONS OF VELOCITY COMPONENTS ARE PUNCHED ON CARDS FOR FURTHER PROCESSING. $1200-C H A R A C T E R$ RECORDS ARE READ INTO STORAGE BY MEANS OF A MACHINE LANGUAGE SUBROUTINE. THE REMAINING PROGRAM IS IN FORTRAN. AUTHOR-- EMANUEL MEHR, COLLEGE OF ENGINEERING, NYU.

NEW YORK UNIVERSITY

SCHOOL OF ENGINEERING AND SCIENCE

GEOPHYSICAL SCIENCES LABORATORY

2455 SEDGWICK AVE., BRONX, N.Y. 10468

DATUBA

LANGUAGE - FORTRAN-63

COMPUTER - CDC 3800

ANALYZES THE DEFLECTIONS OF A TRI-MOORED, SUBSURFACE, BUOY-CABLE ARRAY ACTED ON BY CURRENT-INDUCED FORCES. SOLUTION IS BY THE METHODS OF 
IMAGINARY REACTIONS AND SUCCESSIVE APPROXIMATIONS. CALCULATES THE HYDRODYNAMIC FORCES, AND BOTH NORMAL AND TANGENTIAL DRAGS ARE INCIUUDED. DOCUMENTED IN NRL REPORT 6894 (MAY 1969), BY R.A. SKOP AND R.E. KAPLAN. MEMORY REQUIREMENTS-- APPROX. 16000 WORDS FOR THE ARRAYS IN COMMON AND 2100 WORDS FOR THE MAIN PROGRAM AND SUBPROGRAMS.

NAVAL RESEARCH LABORATORY

4555 OVERLOOK AVENUE, S.W.

WASHINGTON, D. C. 20390

( COPY ON FILE AT NODC)

COMPUTER - IBM 1800 SYS

COMPUTES THE EQUILIBRIUM CONFIGURATION AND TENSIONS OF A CABLE TOWING A SUBMERGED BODY FOR FAIRED, UNFAIRED, AND DISCONTINUOUS (LOWER PART FAIRED) CABLES. THE OUTPUT ON THE LINE PRINTER GIVES THE VALUES OF THE INPUT DATA FOLLOWED BY VARIOUS CALCULATED VALUES. THE SOLUTION IS FOUND FOR THE 'HEAVY GENERAL CABLE' LAW OF CABLE LOADINGS AS DESCRIBED BY M.C. EAMES (1968). EXECUTION TIME-- ABOUT 30 SECS. FOR EACH CASE. N.I.O. PROGRAM NO. 168. AUTHOR-- CATHERINE CLAYSON.

NATIONAL INSTITUTE OF OCEANOGRAPHY

WORMLEY, GODALMING, SURREY

ENGLAND

READS, CALIBRATES AND PLOTS DATA FROM BERGEN OR PLESSEY CURRENT METERS. DATA IS READ FROM CARDS. ANY ONE OF THE READINGS MAY BE TAKEN AS ROTOR COUNT, THE DIFFERENCES BETWEEN CONSECUTIVE READINGS THEN BEING USED BY THE PROGRAM AS THE BASIS OF CURRENT SPEED. THREE GRAPHS MAY BE PLOTTED (E•G. SPEED, DIRECTION, AND TEMPERATURE) • ALL RESULTS ARE ALSO OUTPUT TO MAGNETIC TAPE. N.I•O. PROGRAM 111 BY W.T.J. SI_ADE. WRITE-UP IN N.I.O. INTERNAL REPORT NO. N.12, DEC 1968.

NATIONAL INSTITUTE OF OCEANOGRAPHY

WORMLEY, GODALMING, SURREY

ENGLAND

CURRENT METER CONVERSION

LANGUAGE - FORTRAN IV

COMPUTER - IBM 1800 SYS

CONVERTS RAW CURRENT METER DATA INTO CALIBRATED OUTPUT FOR RECORDING ON BOTH LINE-PRINTER AND MAGNETIC TAPE. N.I.O. SUB-PROGRAM - II, BY W.T.J. SLADE (REF. N.I.O. INTERNAL REPORT NO. N.12).

NATIONAL INSTITUTE OF OCEANOGRAPHY WORMLEY, GODALMING, SURREY

ENGLAND

VEL LANGUAGE - FORTRAN IV-H COMPUTER - SDS SIGMA 7

COMPUTES GEOSTROPHIC VELOCITY DIFFERENCE BETWEEN TWO OCEANOGRAPHIC STATIONS, ACCORDING TO A FORMULA DESCRIBED BY N.P. FOFONOFF AND CHARLOTTE FROESE. (PROGRAM WRITTEN AS SUBROUTINE - NO I/P OR O/P)

INFORMATION PROCESSING CENTER

ATTN. MARY HUNT

WOODS HOLE OCEANOGRAPHIC INSTITUTION

WOODS HOLE, MASSACHUSETTS 02543 
INFORMATION PROCESSING CENTER

ATTN. MAFYY HUNT

WOODS HOLE OCEANOGRAPHIC INSTITUTION

WOOOS HOLE, MASSACHUSETTS 02543

PRODUCES A TWO DIMENSIONAL FREQUENCY DISTRIBUTION OF SAMPLES AVERAGED OVER CHOSEN INTERVAL AGAINST TIME. INPUT-- CONTROL CARDS AND 9-TRACK MAG. TAPE. OUTPUT-- A LINE PRINTER PLOT OF AVERAGED COMPASS, VANE, DIRECTION, AND SPEED AGAINST TIME.

INFORMATION PROCESSING CENTER

ATTN. JOHN A. MALTAIS

WOODS HOLE OCEANOGRAPHIC INSTITUTION

WOODS HOLE, MASSACHUSETTS 02543

VECTAV

LANGUAGE - FORTRAN IV-H

COMPUTER - SDS SIGMA 7

PRODUCES A NINE TRACK MAG. TAPE IN WHOI FORMAT OF EAST AND NORTH VELOCITY VECTOR AVERAGES AND THEIR CORRESPONDING POLAR REPRESENTATIONS. INPUT-- CONTROL CARDS AND DATA ON 9-TRACK TAPE.

INFORMATION PROCESSING CENTER

ATTN. JOHN A. MALTAIS

WOODS HOLE OCEANOGRAPHIC INSTITUTION

WOODS HOLE, MASSACHUSETTS 02543

PROVEC

LANGUAGE - FORTRAN IV-H COMPUTER - SDS SIGMA 7

COMPUTES PROGRESSIVE VECTORS FROM DIRECTION AND SPEED VALUES. INPUT-CONTROL CARDS AND 9-TRACK MAG. TAPE IN WHOI FORMAT. OUTPUT-- LISTING, ON LINE PRINTER, OF PROGRESSIVE VECTORS AND/OR A MAG. TAPE TO BE USED WITH A PDP-5 DRIVEN CALCOMP FOR A PLOT OF THE VECTORS.

INFORMATION PROCESSING GENTER

ATTN. JOHN A. MALTAIS

WOODS HOLE OCEANOGRAPHIC INSTITUTION

WOODS HOLE, MASSACHUSETTS 02543

**** ICE IN THE SEA *-*-*

ICEGRID MODIFIED

(COPY ON FILE AT NODC)

INCORPORATES PROGRAMS 'ICEMELT' AND 'ICEGRID'. TAKES INTO CONSIDERATION THE EFFECTS OF MELTING ON THE PRODUCTION OF FIVE-DAY FORECASTS OF THE WIND DRIFT AND CONCENTRATION OF SEA ICE, USING EQUATIONS AFTER ZUBOV AND AN EARLIER PROGRAM OF KNODLE. USES A $26 \times 21$ GRID-POINT ARRAY WITH VARIABLE SCALE. OUTPUT FIELDS ARE CONCENTRATION, DIRECTION AND DISTANCE OF MOVEMENT. DOCUMENTED IN THESIS BY KENNETH M. IRVINE IUNPUBLISHED, 1965 !

NAVAL POSTGRADUATE SCHOOL MONTEREY, CALIFORNIA 93940
COMPUTER - IBM 1604
LANGUAGE - FORTRAN 60 
PROCESSES OBSERVED SEA ICE CONDITIONS 50 THEY CAN BE USED IN FORECASTING SEA ICE CONDITIONS. OS NO. 20141. AUTHOR-- L.A. WALKER.

DATA SYSTEMS CENTER, CODE 0831

NAVAL OCEANOGRAPHIC OFFICE

SUITLAND, MD. 20390

STATISTICAL ANALYSIS OF ICE DATA

LANGUAGE - FORTRAN

COMPUTER - IBM 7074

COMPUTES THE MEAN CONCENTRATION VALUES, MEAN AGE SEVERITY VALUES, AND MEAN FLOE SIZE SEVERITY VALUE OF ICE DATA. AUTHOR - BARBARA GRAY.

OCEANOGRAPHIC PREDICTION, CODE 3400

NAVAL OCEANOGRAPHIC OFFICE

SUITLAND, MD. 20390

\section{SEA ICE STUDIES}

LANGUAGE - FORTRAN IV

(COPY ON FILE AT NODC)

COMPUTER - IBM $7090 / 94$

A GENERALIZED PROGRAM WITH SEVERAL OPTIONS THAT ALLOW CONSIDERABLE LATITUDE IN THE SPECIFICATION OF INPUT AND OUTPUT DATA. A MAIN PROGRAM READS IN THE INPUT DATA AND SUMMARIZES THE RESULTS OF EACH YEAR'S INTEGRATION. SUBROUTINE YARIT CALCULATES THE TEMPERATURE AND THICKNESS CHANGES OF THE ICE AND SNOW FOR EACH TIME STEP DURING THE YEAR. SUBROUTINE FLIP TAKES THE MONTHLY VALUES OF THE INDEPENDENT ENERGY FIUXES AT THE UPPER BOUNDARY AND PRODUCES SMOOTHED VALUES FOR EACH TIME STEP. SUBROUTINE SALPR CALCULATES THE SALINITY PROFILE FOR EACH TIME STEP. FINALLY, SUBROUTINE RITE WRITES THE TEMPERATURE PROFILE, ICE THICKNESS AND MASS CHANGES FOR EACH 1O-DAY PERIOD THROUGHOUT THE YEAR. LISTED IN A MEMORANDUM RM-6093-PR (NOV 1969, 173 P) 'NUMERICAL PREDICTION OF THE THERMODYNAMIC RESPONSE OF ARCTIC SEA ICE TO ENVIRONMENTAL CHANGES ' BY G.A. MAYKUT AND N. UNTERSTEINER. PREPARED FOR U.S. AIR FORCE PROJECT RAND.

THE RAND CORPORATION

1700 MAIN ST.

SANTA MONICA, CALIF. 90406

* * - physical properties - anAlyses and summaries - * *

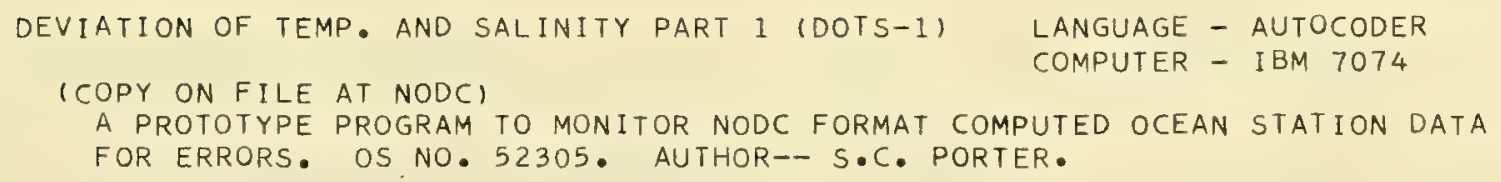

OBJECTIVE THERMOCLINE ANALYSIS

$$
\begin{aligned}
& \text { LANGUAGE - } \text { FORTRAN IV }-H \\
& \text { COMPUTER - IBM } 360 \text { SER. } \\
& \text { AND CDC } 6500
\end{aligned}
$$

(COPY ON FILE AT NODC)

READS DIGITIZED BATHYTHERMOGRAPH TRACES AND THEN ANALYZES THEM OBJECTIVELY BY GAUSSIAN AND NON-GAUSSIAN METHODS FOR THE TOP, CENTER, AND

BASE OF THE MAIN THERMOCLINE. ADDITIONALLY, SUCH FEATURES AS MULTIPLE 
THERMOCLINES, INVERSIONS, AND THERMAL TRANSIENTS ARE IDENTIFIED ALSO AND THEIR KEY POINTS ARE INCLUDED IN THE INFORMATIONAL DATA PRINTOUT. THESIS BY ERIC F. GROSFILS IOBJECTIVE DIGITAL ANALYSIS OF BATHYTHERMOGRAPH TRACES, (UNPUBLISHED MANUSCRIPT, DEC. 1968, 130 P).

NAVAL POSTGRADUATE SCHOOL

MONTEREY, CALIFORNIA 93940

GRAOIENT SUMMARY BY I-DEG SQUARE, MONTH

LANGUAGE - AUTUCODER

COMPUTER - IBM 7074

(COPY ON FILE AT NODC)

COMPUTES AND PRINTS AVERAGE TEMPERATURE GRADIENTS FOR EACH 20 METER

DEPTH INTERVAL, BY EACH OF 12 MONTHS, ALONG WITH THE NUMBER OF OBS THE MEAN IS BASED ON. ANY SIGNIFICANT POSITIVE GRADIENTS (INCREASE OF O.2 DEG. C/2OM OR MORE) SUMMARIZED SEPARATELY ON SAME PAGE. INPUT IS NODC DIGITIZED BT FILE, SORTED GEOGRAPHICALLY. OS NO. 6240I. AUTHOR-- JEFF GORDON (REVISED JULY 1969 ).

COMPUTER SYSTEMS DIV., CODE 2400

NATIONAL OCEANOGRAPHIC DATA CENTER

WASHINGTON, D. C. 20390

THERMOCLINE AND MIXED LAYER DEPTHS

LANGUAGE - AUTOCODER

COMPUTER - IBM 7074

(COPY ON FILE AT NODC)

DETERMINES AND PRINTS OUT THE DEPTHS OF THE MIXED LAYER AND TOP OF THE THERMOCLINE FOR INDIVIDUAL BT OBSERVATIONS, WITH MEANS FOR EACH MONTH WITHIN A 1-DEGREE SQUARE. USES GRADIENT CRITERIA GIVEN BY CODE 2120 SCIENTIST (BASED LARGELY ON NODC'S GRADIENT SUMMARY PROGRAM OUTPUT), AND ENTERED ON CONTROL CARDS. COMPARISON IS MADE WITH ABSOLUTE VALUE OF GRADIENT/ 1OM. OS NO.62402. AUTHOR-- JEFF GORDON (JULY 1969)•

COMPUTER SYSTEMS DIV., CODE 2400

NATIONAL OCEANOGRAPHIC DATA CENTER

WASHINGTON, D. C. 20390

S.E.R.C. BT ANALYSIS

LANGUAGE - AUTOCODER

COMPUTER - IBM 7074

(COPY ON FILE AT NODC)

ERROR CHECKS DATA AND COMPUTES LAYER DEPTH, SURFACE EFFECT, MEAN GRADIENT, MAXIMUM NEGATIVE GRADIENT, ASCENDANT AND FIRST NEGATIVE GRADIENT. A SOUND VELOCITY COMPUTATION IS ALSO MADE. OS NO. 20113. REPORT NO. 0-31-63 (UNPUBIISHED MANUSCRIPT). AUTHOR-- M.E. MYERS.

COMPUTER DEPARTMENT, CODE 0831

NAVAL OCEANOGRAPHIC OFFICE

SUITLAND, MD. 20390

GDNP, GRAD

LANGUAGE - FORTRAN IV

COMPUTER - IBM $360 / 65$ WITH CAI_COMP

CALCULATES THE GRADIENTS OF DENSITY, TEMPERATURE, AND SALINITY AS FUNCTIONS OF SIGMA-T ALONG 4 STANDARD SECTIONS IN THE TRADE WIND ZONE OCEANOGRAPHY PROGRAM PILOT STUDY AREA. CALCOMP DIGITAL PLOTTER REOUIRED FOR PROGRAM 'GRAD'.

BUREAL OF COMMERCIAL FISHERIES

P. O. BOX 3830

HONOLULU, HAWAII 96812 
EXCEPTIONS TO THE INTERVALS WITH THEIR CORRESPONDING DEPTH ANU THE

MEAN GRADIENT FOR EACH DEPTH IS PRINTED ALSO. OS NO. 10120 . AUTHOR -

M.V. JENNINGS.

COMPUTER DEPARTMENT, CODE 0831

NAVAL OCEANOGRAPHIC OFFICE

SUITLAND, MD. 20390

MONTHLY SONIC LAYER DEPTH

LANGUAGE - FORTRAN

COMPUTER - IBM 7074

CALCULATES SONIC LAYER DEPTH FROM BT TRACES AND CONVERTS POSITION TO PLOT ON MERCATOR BASE WITHOUT OVERPRINTS. OS NO. 53480. AUTHOR-- D.B. NIX.

OCEANOGRAPHIC PREDICTION DIV , CODE 3400

NAVAL OCEANOGRAPHIC OFFICE

SUITLAND, MD. 20390

SEA SURFACE TEMPERATURE DISTRI B̃UTION

LANGUAGE - FORTRAN

COMPUTER - IBM 7074

( COPY ON FILE AT NODC)

TABULATES THE FREQUENCY, PERCENT FREQ., CUMULATIVE PERCENT FREQ., AND

MEAN TEMPERATURE FOR ALL ONE-DEGREE SQUARES AND MONTHS PROVIDED BY

SEA SURFACE TEMPERATURE SUMMARY CARDS FROM ASHEVILLE, N. C. OS NO.

20136. AUTHOR-- J. LECKIE.

COMPUTER DEPARTMENT, CODE 0831

NAVAL OCEANOGRAPHIC OFFICE

SUITLAND, MD. 20390

TEMPERATURE DISTRIBUTION BY ONE-DEGREE SQUARES LANGUAGE - FORTRAN

( COPY ON FILE AT NODC)

COMPUTER - IBM 7074

COMPUTES AND TABULATES A FREQUENCY DISTRIBUTION FOR SELECTED TEMPER-

ATURE INTERVALS AND STANDARD DEPTHS, AND THE MAXIMUM, MINIMUM, AND

MEAN VALUES OF TEMPERATURE FOR EACH STANDARD DEPTH. A REPORT IS PRO-

DUCED FOR EACH ONE-DEGREE SQUARE. OS NO. 20126 PART 5. AUTHOR-- C.S.

CALDWELL.

COMPUTER DEPARTMENT, CODE 083

NAVAL OCEANOGRAPHIC OFFICE

SUITLAND, MD. 20390

TEMPERATURE AVERAGE SUMMARY BY I-DEGREE SQUARES LANGUAGE - FORTRAN

(COPY ON FILE AT NODC)

COMPUTER - IBM 7074

COMPUTES FOR EACH ONE-DEGREE SQUARE WITHIN A MARSDEN SQ., FROM GEO-

GRAPHIC STATION DATA, A SEASONAL AVERAGE AND FREQUENCY AND A TWELVE MONTH AVERAGE AND FREQUENCY, AT EACH OF FOURTEEN SELECTED STANDARD

DEPTHS. OS NO. 20123. AUTHOR-- C.S. CALDWELL.

COMPUTER DEPARTMENT, CODE 083

NAVAL OCEANOGRAPHIC OFFICE

SUITLAND, MD. 20390

VERTICAL TEMPERATURE GRADIENTS

LANGUAGE - FORTRAN

COMPUTER - IBM 7074

( COPY ON FILE AT NODC)

COMPUTES, FROM GEOGRAPHIC STATION DATA, THE VERTICAL TEMPERATURE GRADIENT LARGEST IN ABSOLUTE MAGNITUDE BETWEEN SUCCESSIVE STANDARD DEPTHS, FOR EACH STATION. THESE GRADIENTS ARE TABULATED IN FREQUENCY DISTRIBUTION FORMAT, AND AVERAGES ARE CALCULATED FOR EACH ONE-DEGREE SQUARE. OS NO. 20126 PART 2. AUTHOR-- C.S. CALDWELL. 
(COPY ON FILE AT NODC)

COMPUTES, FROM GEOGRAPHIC STATION DATA, THE VERTICAL SIGMA-T GRADIENT LARGEST IN ABSOLUTE MAGNITUDE BETWEEN SUCCESSIVE STANDARD DEPTHS, FOR EACH STATION. THESE GRADIENTS ARE TABULATED FOR FREQUENCY DISTRIBUTION FORMAT, AND AVERAGES ARE CALCULATED FOR EACH 1-DEG SQ. OS NO. 20122. AUTHOR-- C.S. CALDWELL.

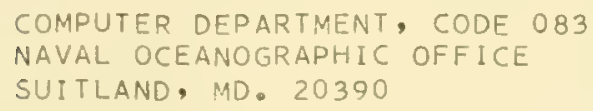

THERMOCLINE ONE-DEGREE

LANGUAGE - AUTOCODER COMPUTER - IBM 7074

( COPY ON FILE AT NODC)

PRODUCES A DESCRIPTION OF THE THERMOCLINE BY DEFINING THE TOP, BOTTOM, MAGNITUDE, AND INTENSITY OF THE THERMOCLINE AND THE MOST EXTREME INTENSITY WITHIN THE THERMOCLINE. THE PRINTED REPORT CONTAINS THE ABOVE QUANTITIES FOR EACH STATION WITHIN A I-DEGREE SQUARE, ALSO AVERAGE VALUES FOR THE 1-DEGREE SQUARE. IN PRODUCTION MODE, THE PROGRAM USES A CONSTANT THERMOCLINE CRITERION. IN THE TEST MODE, THE CRITERION MAY BE INCREMENTED FOR ANOTHER PASS OF THE SAME DATA TAPE. OS NO. 20126, PART 4. AUTHOR-- C.S. CALDWELL.

COMPUTER DEPARTMENT, CODE 083

NAVAL OCEANOGRAPHIC OFFICE

SUITLAND, MARYLAND 20390

SAL INITY GRADIENT BY ONE-DEGREE SQUARE

LANGUAGE - FORTRAN

(COPY ON FILE AT NODC)

COMPUTER - IBM 7074

COMPUTES, FROM GEOGRAPHIC STATION DATA, THE VERTICAL SALINITY GRADIENT LARGEST IN ABSOLUTE MAGNITUDE BETWEEN SUCCESSIVE STANDARD DEPTHS, FOR EACH STATION. THIS INFORMATION IS TABULATED IN FREQUENCY DISTRIBUTION FORM, AND AVERAGES ARE CALCULATED FOR EACH ONE-DEGREE SQUARE. THE FREQUENCY INTERVAL IS $0.010 / 00 / M$ BETWEEN LIMITS OF -0.5 AND + $2.50 / 00 / M$. OS NO. 20121. AUTHOR-- C.S. CALDWELL.

COMPUTER DEPARTMENT, CODE 083

NAVAL OCEANOGRAPHIC OFFICE

SUITLAND, MD. 20390

\section{SALINITY DEVIATION COMPUTATION WITH PLOT \\ LANGUAGE - FORTRAN \\ COMPUTER - IHM 7074}

( COPY ON FILE AT NODC)

THE DEVIATIONS OF SALINITY FROM RELATED MODELS ARE COMPUTED FOR SERIAL OCEANOGRAPHIC STATION DATA AND A SALINITY PROFILE PLOTTED. OS NO. 52301. AUTHOR-- S.C. PORTER.

DEVELOPMENT DIVISION, CODE 2320

NATIONAL OCEANOGRAPHIC DATA CENTER

WASHINGTON, D. C. 20390

STATION DATA VERTICAL ARRAY SUMMARY

LANGUAGE - AUTOCODER COMPUTER - $1 B M 7074$

(COPY ON FILE AT NODC)

SUMMARIZES FOR ANY COMBINATION OF SIX PARAMETERS ITEMPERATURE, SAL_INITY, SIGMA-T, OXYGEN, SOUND VELOCITY, DYNAMIC DEPTHI AND COMPUTES MAXIMUM AND MINIMUM VALUES, NUMBER OF OBSERVATIONS, MEANS AND STANDARD DEVIATIONS AT STANDARO LEVELS. SUMMARIES MAY BE MONTHLY OR YEARLY AND 
BY SELECTED ONE-DEGREE SQUARES. THERE IS AN OPTION TO GENERATE A SPECIAL CONDENSED TAPE FOR INPUT TO A HISTOGRAM PLOT PROGRAM. OS NO. 52257. AUTHOR-- MAXINE JACKSON.

COMPUTER SYSTEMS DIVISION

NATIONAL OCEANOGRAPHIC DATA CENTER

WASHINGTON, D.C. 20390

MARSDEN SQUARE AVERAGES FROM OCEAN STATION GEO-SORTED FILE

(COPY ON FILE AT NODC)

CALCULATES AVERAGE SEA SURFACE SOUND VELOCITY, AVERAGE LAYER DEPTH, AVERAGE DEPTH OF THE SOUND CHANNEL AXIS. AND AVERAGE SOUND VELOCITY AT THE SOUND CHANNEL AXIS. THESE VALUES ARE CALCULATED FOR EACH ONE-DEGREE QUADRANGLE FOR EACH MONTH. A SUBPROGRAM 'AREAD' IS CALLED WHICH GAINS ACCESS TO THE NODC ARCHIVE TAPE FILE OF SORTED OCEANOGRAPHIC DATA. REF. INFORMAL REPORT IR NO. 67-95 (DEC 1967), ENTITLED IEXTRACTING INFORMATION FROM THE GEO-SORT FILE BY COMPUTER PROGRAMING', BY J. C. FRANCE, OCEANOGRAPHIC ANALYSIS DIVISION, CODE 3316. FURTHER INFORMATION MAY BE OBTAINED FROM DISSEMINATION DEPT. CODE 44, OR THE AUTHOR

NAVAL OCEANOGRAPHIC OFFICE

WASHINGTON, D.C. 20390

STATION DATA PARAMETER INVENTORY

LANGUAGE - FORTRAN

COMPUTER - IBM 7074

( COPY ON FILE AT NODC)

LISTS GEOSORTED STATION DATA, ONE LINE FOR EACH STATION, SHOWING, BESIDES NORMAL IDENTIFICATION FIELDS, THE DEPTH TO BOTTOM, MAXIMUM SAMPLE DEPTH, PRESENCE OR ABSENCE OF WATER COLOR AND TRANSPARENCY CODES, MAXIMUM DEPTH OF SOUND VELOCITIES, MINIMUM DEPTH, AND A VERTICAL_ INDICATOR WHICH IS THE ARITHMETIC AVERAGE OF VERTICAL SAMPLE SPACING IN TENS OF METERS. OS NO 52230. ALSO, PROGRAM CAN WRITE OUTPUT, INTERNAL NOTATION, FOR INPUT TO A PLOTTER PROGRAM (OS NO. 52229). AUTHOR ROBERT VAN WIE.

COMPUTER SYSTEMS DIVISION

NATIONAL OCEANOGRAPHIC DATA CENTER

WASHINGTON, D.C. 20390

DAILY SEAWATER OBSERVATIONS

LANGUAGE - FORTRAN IV

COMPUTER - CDC 3100

INPUTS DAILY OBSERVATIONS OF TEMPERATURE AND SALINITY AND OUTPUTS (1) QUARTERLY STATISTICS (2) ANNUAL STATISTICS (3) A LISTING OF SEVEN-DAY NORMALLY WEIGHTED MEANS FOR ONE YEAR (4) A PLOT OF NORMALLY WEIGHTED MEANS FOR ONE YEAR. AUTHOR-- H. SOMERS. EARLY VERSION IN FORTRAN IID FOR THE IBM 1620 .

CANADIAN OCEANOGRAPHIC DATA CENTRE

615 BOOTH STREET

OTTAWA, CANADA

OCEANOGRAPHIC SUMMARY (NOS. $1,2,3$ )

LANGUAGE - FORTRAN IV

COMPUTER - IBM $360 / 65$

SUMMARIZES TEMPERATURE, SALINITY, DEPTH AND OXYGEN BY I-DEGREE SQUARES AND OTHER DEGREE AREAS WITHIN SELECTED MARSDEN SQUARES, AT SELECTED SIGMA-T LEVELS. VERSIONS OF PROGRAM FOR CARD OR TAPE INPUT, AND EITHER CHART OR VERTICAL SECTION OUTPUT.

BUREAU OF COMMERCIAL FISHERIES BIOLOGICAL LAB.

ATTN. DR • R • A. BARKLEY . OCEANOGRAPHER

P.O. BOX 3830

HONOLULU, HAWAII 96812 
(COPY ON FILE AT NODC)

EVALUATES NOMAD INAVAL OCEANOGRAPHIC ANO METEOROLOGICAL AUTOMATIC DEVICE, BUOY DATA, AND OUTPUTS A DISPLAY OF EACH OF THE 5 METEOROIOOGICAL PARAMETERS. THE DISPLAY IS PRINTED BY THE IBM 140I. IN ADDITION TO

THE DISPLAY, THE PROGRAM TOTALS THE NUMBER OF OBSERVATIONS MISSING FOR ANY MONTH, AND PRINTS A HISTOGRAM OF THE DATA FOR EACH MONTH. THIS PROGRAM IS ONE OF A CONTINUING SERIES OF COMPUTER PROGRAMS IN PROJECT SEA SENSE. AUTHOR- DIANA LAMAR.

SERVICES DIVISION, CODE 2210

NATIONAL OCEANOGRAPHIC DATA CENTER

WASHINGTON, D.C. 20390

SEA SENSE - LIMIT

LANGUAGE - FORTRAN

COMPUTER - IBM 7074

( COPY ON FILE AT NODC)

COMPARES NOMAD BUOY DATA TO ESTABLISHED NORMALS OF ABSOLUTE VALUES AND

TO ACCEPTABLE MAP DATA. A MONTHLY TOTAL FOR EACH PARAMETER IS COMPUT-

ED AND PRINTED FOR DATA WHICH IS GOOD, BAD, DOUBTFUL AND MISSING. ALSO COMPUTES THE PERCENT OF WIND SPEEDS IN EACH BEAUFORT FORCE CATEGORY

AND PRINTS THIS WITH THE NORMALS EXPECTED FOR THAT MONTH. WIND DIRECTION PERCENTS ARE COMPUTED ACCORDING TO THE Q CATEGORIES OF WIND DIRECTION, AND PRINTED VS. THE NORMALS. ALSO THE MEANS OF NOMAD AND MAP DATA ARE COMPUTED AND PRINTED VS. THE LIMIT MEANS. AUTHOR-- DIANA LAMAR.

SERVICES DIVISION, CODE 2210

NATIONAL OCEANOGRAPHIC DATA CENTER

WASHINGTON, D. C. 20390

SEA SENSE - STANDARD DEVIATION

LANGUAGE - FURTRAN

COMPUTER - IBM 7074

( COPY ON FILE AT NODC)

COMPUTES THE MEAN AND STANDARD DEVIATION FOR EACH OF 5 METEOROLOGICAL PARAMETERS FOR EACH MONTH OF NOMAD BUOY DATA. IF MAP DATA IS AVAILABLE, THE MEANS AND STANDARD DEVIATIONS AND MEANS AND STANDARD DEVIATIONS OF THE DIFFERENCES BETWEEN NOMAD AND MAP DATA ARE COMPUTED. ALSO COMPUTES THE TOTAL MEAN SIGNAL STRENGTH AND THE MEANS FOR EACH SYNOPTIC HOUR. AUTHOR-- DIANA LAMAR.

SERVICES DIVISION, CODE 2210

NATIONAL OCEANOGRAPHIC DATA CENTER

WASHINGTON, D. C. 20390

SYNOPTIC MARINE WEATHER DATA SUMMARY

LANGUAGE - FORTRAN-62

COMPUTER - CDC 3600

COMPILATION OF MONTHLY SEA SURFACE TEMPERATURES ANO ANOMALIES IDEGREES CENTIGRADE), AIR TEMPERATURES (DEGREES CENTIGRADE), DEWPUINT TEMPERATURES (DEGREES CENTIGRADE), BAROMETRIC PRESSURES (MILLIBARS), XAND Y - WIND VECTORS (KNOTS), WIND SPEEDS (KNOTS), CLOUD COVER (TENTHS OF SKY COVERED), AND HEAT BUDGET VALUES (ENERGY EXCHANGE ACROSS AIRSEA INTERFACE IN CALORIES/CENTIMETER SQUARED/DAYI WITH NUMBER OF OBSERVATIONS BY FIVE DEGREE QUADRANGLES - PACIFIC OCEAN. AUTHOR-- MARVIN W. CLINE

DIRECTOR

FISHERY OCEANOGRAPHY CENTER

BUREAU OF COMMERCIAL FISHERIES

P.O. BOX 271

LA JOLLA, CALIFORNIA 92038 
COMPILATION OF MONTHLY SEA SURFACE TEMPERATURES (DEGREES FAHRENHEIT) WITH NUMBER OF OBSERVATIONS BY ONE-DEGREE QUADRANGLES - PACIFIC OCEAN.

DIRECTOR

FISHERY OCEANOGRAPHY CENTER

BUREAU OF COMMERCIAL FISHERIES

P.O. BOX 271

LA JOLLA, CALIFORNIA 92038

SEA SURFACE TEMPERATURE AND ANOMALY SUMMARY

LANGUAGE - FORTRAN-62

COMPUTER - CDC 3600

COMPILATION OF MONTHLY SEA SURFACE TEMPERATURES IDEGREES FAHRENHEIT AND CENT IGRADE, AND ANOMALIES FROM LONG TERM MEAN WITH NUMBER OF OBSERVATIONS BY TWO-DEGREE QUADRANGLES - PACIFIC OCEAN.

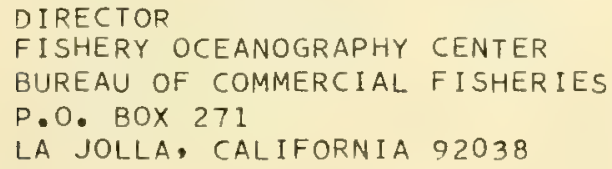

HEMISPHERIC SEA SURFACE TEMPERATURE ANALYSIS

\author{
LANGUAGE - MACHINE \\ COMPUTER - CDC 1604
}

(A) MAINTAINS UP-TO-DATE LARGE SCALE SYNOPTIC SEA SURFACE TEMPERATURE DISTRIBUTION FOR NORTHERN HEMISPHERE, (B) SUPPLIES INPUT MATERIAL FOR DETAILED ANALYSIS OF SELECTED LOCAL REGIONS ON A CURRENT BASIS ONI_Y. OUTPUT FROM PROGRAM-- (A) CALCOMP HARD COPY MAP, SCALE 1/6O MILIION, WITH ISOTHERMS AT 2-DEG INTERVALS, (B) $63 \times 63$ ARRAY OF GRID POINT VALUES ON POLAR STEREOGRAPHIC PROJECTION WITH EQUATOR AN INSCRIBED CIRCLE (C) CERTAIN MEAN CHARTS OF SEA SURFACE TEMPERATURE FOR 5 DAYS, 15 DAYS AND MONTHLY. REF. TECHNICAL NOTE NO. 21 (1966).

COMMANDING OFFICER

FLEET NUMERICAL WEATHER CENTRAL

MONTEREY, CALIFORNIA 93940

GG T SEA

$$
\begin{aligned}
& \text { LANGUAGE - MACHINE } \\
& \text { COMPUTER - CDC } 1604
\end{aligned}
$$

CALCULATES THE LOCATION OF LARGE SCALE HYPER-BAROCLINIC ZONES IN THE OCEANS. INPUT IS THE OUTPUT FROM THE SEA SURFACE TEMPERATURE ANALYSIS PROGRAM. OUTPUT ARE ISOLINES OF THE GG PARAMETER. THE DIRECTIONAL SECOND SPACE DERIVATIVE OF THE BASIC PARAMETER IS COMPUTED. CORE STORAGE-- 32000 48-BIT WORDS. ADDITIONAL STORAGE REQUIREMENTS-- ONE MILLION WORD DRUM. DATA IS IN THE STANDARD FNWC FORMAT. DIRECT REQUESTS FOR INFORMATION TO--

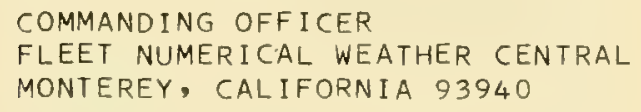

AVERAGE TEMPERATURES IN WATER COLUMN

COMPUTES AVERAGE TEMPERATURE FOR EACH 10 METER LAYER IN WATER COLUMN. AVERAGE COMPUTED FOR EACH 1-DEG. LAT. X 1-DEG. LONG. SQUARE FOR EACH MONTH. INPUT-- DIGITIZED BT DATA. 
1077 NORTH UNIVERSITY BUILDING

ANN ARBOR, MICHIGAN 48104

SUBSURFACE THERMAL STRUCTURE ANALYSIS

LANGUAGE - SCRAP

COMPUTER - CDC 1604

PRODUCES ANALYSIS OF (1) TEMPERATURE AT TOP OF THERMOCLINE (2) TEMPERATURE AT SELECTED SUBSURFACE LEVELS (3) GRADIENT, MAGNITUDE, AND BOTTOM OF THERMOCLINE AND (4) THERMOCLINE TENDENCY AND FLUCTUATIONS. INPUT TO PROGRAM-- (1) SEA SURFACE TEMPERATURE ANALYSIS (2) GRADIENT OF TRANSIENTS (3) PREVIOUS ANALYSIS OF ALL LEVELS (4) CLIMATOLOGY OF ALL LEVELS (5) ANALYSIS OF MIXED LAYER DEPTH, AND CURRENT TRANSPORT (6) BT REPORTS (7) WAVE HEIGHT FORECASTS AND (8) MIXED LAYER DEPTH FORECASTS. INPUT IS IN FNWC STANDARD FORMAT FIELDS. REF. TECH. NOTE NO. 21.

COMMANDING OFFICER

FLEET NUMERICAL WEATHER CENTRAL

MONTEREY, CALIFORNIA 93940

OCEAN STATION DEPTH SUMMARY

LANGUAGE - SPS

COMPUTER - IBM 1401

( COPY ON FILE AT NODC)

USES THE NODC MASTER CARD FILE FOR OCEAN STATIONS WORLDWIDE, WHICH, IN ADDITION TO ALL IDENTIFICATION FIELDS, CONTAINS DEPTH TO BOTTOM AND MAXIMUM SAMPLE INFORMATION. THE RECORDS ARE PUT ON TAPE, GEO-SORTED, ZONE-EDITED AND BLOCKED. THE FILE IS UPDATED SEMIANNUALLY. THE SUMMARY PROGRAM, REQUESTED BY NAVOCEANO MARINE SCIENCES DEPT., MAKES A TALLY OF THE NUMBER OF STATIONS WITH MAX. SAMPLES WITHIN GIVEN INTERVALS, WITHIN A GIVEN DISTANCE FROM THE BOTTOM, ETC. TOTAL COUNTS ARE PRINTED FOR EACH MARSDEN SQ., AND GRAND TOTALS FOR THE FILE. OS NO. 52286. AUTHOR-- C. DINGER

COMPUTER SYSTEMS DIVISION

NATIONAL OCEANOGRAPHIC DATA CENTER

WASHINGTON, D. C. 20390

*-*-* PHYSICAL QUANTITIES, COMPUTATION OF *-*-*

STATION DATA COMPUTE

LANGUAGE - AUTOCODER

COMPUTER - IBM 7074

(COPY ON FILE AT NODC)

INTERPOLATES FOR TEMPERATURE, SALINITY, AND OXYGEN AT STANDARD DEPTHS. COMPUTES SIGMA-T AND WILSON'S SOUND SPEED AT OBSERVED AND STANDARD DEPTHS, COMPUTES SPECIFIC VOLUME ANOMALY AND DYNAMIC DEPTH ANOMALY AT STANDARD DEPTHS. OS NO. 52251, AUTHOR-- MAXINE JACKSON. ANOTHER PROGRAM FOR NODC STATION DATA COMPUTATIONS WAS WRITTEN LATER FOR THE GE$235 / D A T A N E T 30$ SYSTEM IN BASIC LANGUAGE, BY JIM NOEL. CURRENTLY, THE ' COMPUTE, PROGRAM IS BEING REWRITTEN IN PL/I FOR THE IBM OS/360, BY MAXINE JACKSON AND MICHAEL FLANAGAN.

COMPUTER SYSTEMS DIVISION NATIONAL OCEANOGRAPHIC DATA CENTER WASHINGTON, D. C. 20390

BATHYTHERMOGRAPH DATA CONVERTER

LANGUAGE - AUTÚCODER

COMPUTER - IBM 7074

( COPY ON FILE AT NODC)

CONVERTS BT TEMPERATURE DATA FROM 10 FEET - FAHRENHEIT, 2 FATHOMS FAHRENHEIT, 6 METERS - CENTIGRADE TO 5 METERS - CENTIGRADE INTERVALS. OS NO. 22253. AUTHOR-- MAXINE JACKSON. NODC HAS ALSO IN THE PROGRAM LIBRARY A FORTRAN LANGUAGE ROUTINE TO CONVERT BT DATA, NODC FORMAT, 
FROM FAHRENHEIT/FEET AT $10 \mathrm{FT}$. INTERVALS TO CELSIUS/METERS AT 5 METER INTERVALS USING LINEAR INTERPOLATION. AUTHOR-- RUDI SAENGER. OS NO. 52202 .

COMPUTER SYSTEMS DIVISION

NATIONAL OCEANOGRAPHIC DATA CENTER

WASHINGTON, D. C. 20390

NIO PROGRAM 58 ATLAS - STATION DATA

\author{
LANGUAGE - EMA \\ COMPUTER - ATLAS 1
}

VARIOUS PROPERTIES OF SEA WATER ARE CALCULATED FROM THE SETS UF READINGS OF PRESSURE (OR DEPTH), TEMPERATURE AND SALINITY TAKEN AT A STATION. SOME RESULTS ARE GIVEN AT OBSERVED, AND SOME AT STANDARD, PRESSURES. THERE ARE SEVERAL VERSIONS OF THIS PROGRAM DEPENDING UN WHETHER PRESSURE OR DEPTH IS INPUT. AUTHOR-- JAMES CREASE. REF • N.I.O. INTERNAL REPORT NO. NG.

NATIONAL INSTITUTE OF OCEANOGRAPHY WORMLEY, GODALMING, SURREY

ENGLAND

INTERPOLATION OF SPECIFIC VOLUME ANOMALY

LANGUAGE - FORTRAN

(COPY ON FILE AT NODC)

COMPUTER - IBM 7074

COMPUTES SPECIFIC VOLUME ANOMALIES AND DYNAMIC DEPTH ANOMALIES AT OBSERVED LEVELS. FIELDS OCCUPY THE SAME POSITIONS AS ON THE NODC FORMAT STANDARD CARD AND REPLACE SOME CHEMISTRY FIELDS. AT STANDARD DEPTHS SPECIFIC VOLUME ANOMALIES ARE INTERPOLATED FROM THE OBSERVED LEVEIS RATHER THAN COMPUTED FROM INTERPOLATED TEMPERATURE AND SALINITY AS HAS BEEN DONE PREVIOUSLY. DYNAMIC DEPTH ANOMALIES AT THESE STANDARD

DEPTHS ARE THEN COMPUTED FROM THESE INTERPOLATED SPECIFIC VOLUME ANOMALIES. AN OUTPUT LISTING MAY BE MADE WHICH COMPARES THE TWO FIELDS AT STANDARD DEPTHS WITH THE SAME TWO FIELDS APPEARING ON THE INPUT DATA TO SHOW THE RESULTANT DIFFERENCES. OS NO. 52232. AUTHOR-- RUBERT VAN WIE.

COMPUTER SYSTEMS DIVISION, CODE 2400

NATIONAL OCEANOGRAPHIC DATA CENTER

WASHINGTON, D.C. 20390

INTERPOLATION FOR OCEANOGRAPHIC DATA

$$
\begin{aligned}
& \text { LANGUAGE - FORTRAN } \\
& \text { COMPUTER - CDC } 3200 \text { AND }
\end{aligned}
$$

( COPY ON FILE AT NODC)

INTERPOLATES THE VALUES OF DEPTH, TEMPERATURE, AND SALINITY AT ISENTROPIC LEVELS (CONSTANT VALUES OF THE DENSITY FUNCTIONS). USES A FOURPOINT LAGRANGIAN POLYNOMIAL, EXCEPT MODIFICATIONS ARE MADE WHERE COMMON OCEANOGRAPHIC CONDITIONS DISTORT THE POLYNOMIAL. A DETAILED TECHNICAL REPORT PUBLISHED IN TM NO. 312 (FEB. 1964), AUTHORS-- J. FARRELL AND R. LAVOIE. COPIES OBTAINABLE FROM DDC, NUWS, NODC.

NAVAL UNDERWATER WEAPONS RESEARCH

AND ENGINEERTING STATION

NEWPORT, RHODE ISLAND 02840

PHYSICAL OCEANOGRAPHY DATA REDUCTION

LANGUAGE - FORTRAN II

PROGRAMS FOR THE CDC 3100

COMPUTER - CDC 3100

(COPY ON FILE AT NODC)

AN OCEANOGRAPHIC DATA PROCESSING SYSTEM DESIGNED TO ACCEPT THE DATA FROM THE ORIGINAL LOG SHEETS. COMPUTES OBSERVED TEMPERATURES AND PRESSURES FROM THERMOMETER READINGS, SALINITIES FROM THE CONDUCTIVITY RATIO READINGS, THE DISSOLVED OXYGEN FROM THE TITRES AND THE REACTIVE SILICA CONCENTRATIONS FROM THE OPTICAL DENSITIES. THE DATA INPUT MAY BE PUNCHED PAPER TAPE FROM THE PDP-8 SYSTEM (B. I COMPUTER NOTE 68-5C) OR PUNCHED CARDS. THE FINAL PROGRAM IN THE SYSTEM COMPUTES DEPTH, 
POTENTIAL. TEMPERATURE, SURFACE DENSITY ANOMALY, POTENTIAL SURFACE DENSI IY ANOMALY AND SPECIFIC VOLUME ANOMALY. THE PROGRAM ALSO CAN COMPUTE THE DYNAMTC HEIGHT AND POTENTIAL ENERGY ANOMALY AT GIVEN PRESSURES AND MAY ALSO GIVE A MAGNETIC TAPE OF THE DATA IN CARD IMAGE OF

THE CONC FORMAT. CORE STORAGE-- I6K. REF. B.I. COMPUTER NOTE 68-10-C (OCT 1968, 280 PAGES), BY R. REINIGER, C.K. ROSS, P. TRITES AIVD D.J. LAMRENCE.

DIRECTOR

ATLANTIC OCFANOGRAPHIC LABORATORY

BEDFORD INST ITUTE

DARTMOUTH, NOVA SCOTIA, CANADA

WET

LANGUAGE - FURTRAN

COMPUTER - HP 2115 A

(COPY ON FILE AT NODC)

FOR SHIPBOARD PROCESSING OF DIGITIZED SALINITY-TEMPERATURE-DEPTH DATA. INPUT IS ON PAPER TAPE (SEE FRB PROGRAM 'DEEP'). OUTPUT ARE PARAMETERS AT STANDARD PRESSURES - TEMPERATURE, SALINITY, SIGMA-T, DELTA-D, SPECIFIC GRAVITY ANOMALY, SPECIFIC VOLUME ANOMALY, GEOPOTENTIAL ANOMALY, AND POTENTIAL ENERGY. DOCUMENTATION IN FRB TECHNICAL REPORT NO. 152 (DECEMBER 1969), BY A. HUYER AND C. A. COLLINS (UNPUBLISHED MS.).

DR. C. A. COLLINS

MARINE SCIENCES BRANCH, DEMR

PACIFIC OCEANOGPAPHIC GROUP

BIOLOGICAL STATION

NANAIMO, B.C., CANADA

STPO2

LANGUAGE - FORTRAN IV

COMPUTER - IBM 1130

(COPY ON FILE AT NODC)

COMPUTES DERIVED OCEANOGRAPHIC QUANTITIES FOR BISSETT-BERMAN S.T.D.

CASTS. PRINTED OUTPUT HAS PRESSURE, TEMPERATURE, SALINITY, DEPTH, SIGMA-T, SPECIFIC VOLUME ANOMALY, POTENTIAL TEMPERATURE AND DENSITY, DYNAMIC HEIGHT, POTENTIAL ENERGY ANOMALY, OXGYEN CONTENT. SOUND VELOCITY OPTIONAL. INPUT DATA IS IN CODC FURMAT. DOCUMENTED IN FRB MANUSCRIPT REPORT (UNPUBLISHED) NO. 1071 (DECEMBER 1969), BY C.A. COLIINS, R.L.K. TRIPE AND S.K. WONG.

DR. C. A. COLLINS

MARINE SCIFNCES BRANCH, DEMR

PACIFIC OCEANOGRAPHIC GROUP

SIOLOGICAL STATION

NANAIMO, E.C., CANADA

HYORO

LANGUAGE - FORTRAN IV

COMPUTER - IBM 1130

(COPY ON FILE AT NODC)

COMPUTES DERIVED OCEANOGRAPHIC QUANTITIES FOR HYDROGRAPHIC CASTS. OUTPUT ON IBM 1132 PRINTER LISTS PRESSURE, TEMPERATURE, SALINITY, DEPTH, SIGMA-T, SPECIFIC VOLUME ANOMALY, POTENTIAL TEMPERATURE AND DENSITY, DYNAMIC HEIGHT, POTENTIAL ENERGY ANOMALY, AND OXYGEN CONTENT, UITH SOUNO VELOCITY OPTIONAL. DESCRIPTION AND LISTINGS IN FRB IUNPUBLISHED) MANUSCRIPT REPORT NO. 1071 (DEC 1969 ).

DR. C. A. COLLINS

MARINE SCIENCES BRANCH, DEMR

PACIFIC OCEANOGRAPHIC GROUP

BIOLOGICAL STATION

NANAIMO, B.C., CANADA 
VARIOUS DEPENDENT QUANTITIES, SUCH AS POTENTIAL TEMPERATURES, SPECIFIC VOLUME ANOMALIES, SIGMAS, AND DYNAMIC HEIGHTS. INTERPOLATES FOR THESE QUANTITIES AT STANDARD DEPTH USING A DOUBLE LAGRANGE'S INTERPOLATION METHOD. FROM A PAIR OF STATIONS WITH A REFERENCE DEPTH, MEAN LATITUDE AND DISTANCE BETWEEN STATIONS, CALCULATES AT STANDARD DEPTHS RELATIVE VELOCITIES AND VOLUME TRANSPORTS. AUTHORS-- MR. MANLEY, L.W. YOUNG.

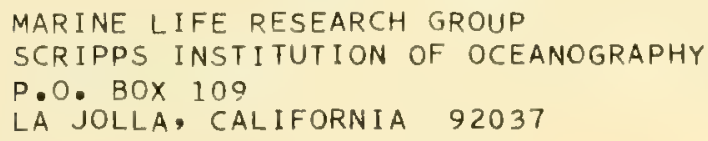

GIVEN DEPTHS, TEMPERATURES, SALINITIES, AND OXYGENS, CALCULATES POTENTIAL TEMPERATURES, SIGMA THETA'S, AND OXYGENS IN UNITS OF ML/KG. AUTHORS-- MR. MANLEY, L. W. YOUNG.

MARINE LIFE RESEARCH GROUP SCRIPPS INSTI TUTION OF OCEANOGRAPHY P.O. BOX 109 LA JOLLA, CALIFORNIA 92037

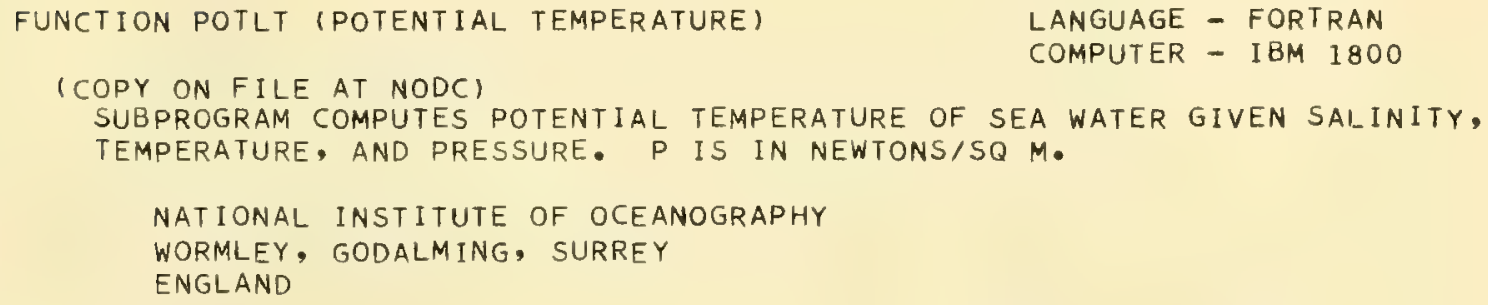

FUNCTION SIGMO

LANGUAGE - FORTRAN

( COPY ON FILE AT NODC)

COMPUTER - IBM 1800

SUBPROGRAM COMPUTES HYDROGRAPHIC FUNCTION SIGMA ZERO FROM SALINITY.

NATIONAL INSTITUTE OF OCEANOGRAPHY

WORMLEY, GODALMING, SURREY

ENGLAND

FUNCTION SIGMT

LANGUAGE - FORTRAN

(COPY CN FILE AT NODC)

COMPUTER - IBM 1800

SUBPROGRAM COMPUTES HYDROGRAPHIC FUNCTION SIGMA-T, FROM SIGMA-O AND TEMPERATURE.

NATIONAL INSTITUTE OF OCEANOGRAPHY

WORMLEY, GODALMING, SURREY

ENGLAND 
COMPUTES SIGMA-T, DELTA ALPHA (SPEC. VOL. ANOM.), OXYGEN PER CENT SATURATION. ICES FORMAT CARD-TO-CARD. OUTPUT CARDS CONTAIN THE COMPUTED PARAMETERS ALONG WITH THE HYDRO DATA. AUTHOR-- MARILYNN BORKOWSKI, MODIFYING AN EARLIER PROGRAM BY D.L. SHAFFER FOR THE IBM 1620.

BUREAU OF COMMERCIAL FISHERIES

TROPICAL ATLANTIC BIOLOGICAL LABORATORY

75 VIRGINIA BEACH DRIVE

MIAMI. FLORIDA 33!40

OCEANS III

LANGUAGE - FORTRAN IV

COMPUTER - IBM $360 / 65$

OCEANOGRAPHIC STATION PROGRAM, USED FOR QUALITY CONTROL, INTERNAL EDITING, UNIT CONVERSION, COMPUTATION OF MARSDEN SQUARE, SIGMA-T, SOUND VELOCITY. ALSO USED FOR INTERPOLATION TO STANDARD DEPTHS USING RATTRAYIS SCHEME ANO COMPUTATION OF SPECIFIC VOLUME ANOMALY, DYNAMIC DEPTH AND POTENTIAL ENERGY ANOMALY. EARLIER VERSION FOR THE IBM 1620 TITLED OCEANS II IS NO LONGER USED AT CODC.

CANADIAN OCEANOGRAPHIC DATA CENTRE

515 BOOTH STREET

OTTAWA, CANADA

DENSITY-SALINITY LINEAR INTERPOLATION

LANGUAGE - FORTRAN

(COPY ON FILE AT NODC)

COMPUTER - IBM 7074

SELECTEO DENSITY-SALINITY VALUES TO REPRESENT THE WATER MASS MIDPOINTS OF PARTICULAR AREAS. LINEARLY INTERPOLATES THESE DENSITY-SALINITY VALUES WITH THE RESULTING SALINITIES GIVEN AT EVERY 0.0I SIGMA-T INCREMENT. OS NO. 52321. AUTHOR-- R.P. STEIN.

DEVELOPMENT DIVISION, CODE 2300

NATIONAL OCEANOGRAPHIC DATA CENTER

WASHINGTON, D. C. 20390

S.T.D. EDIT AND INTERPOLATE

LANGUAGE - FORTRAN

COMPUTER - IBM 1130

EDITS, AVERAGES, AND INTERPOLATES STD DATA TO 3-METER INTERVALS. OUTPUT-- SALINITIES AND TEMPERATURES ON CARDS IN CONDENSED FORMAT, AND A LISTING OF DISCARDED VALUES. PROGRAM NO. UWMS-1130.

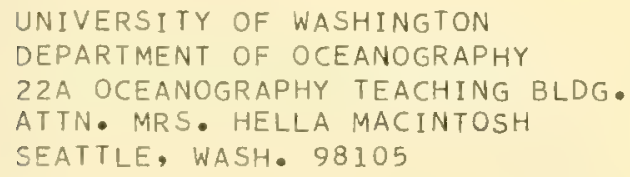

INTERPOLATION

LANGUAGE - FORTRAN IV

COMPUTER - IBM $360 / 65$

INTERPOLATES TEMPERATURE, SALINITY, OXYGEN, PHOSPHATE FOR STANDARD DEPTHS, AND DEPTH, TEMPERATURE, SALINITY, OXYGEN, PHOSPHATE FOR STANDARD SIGMA-T SURFACES. INPUT IS ICES FORMAT DATA. METHOD USED IS MEAN OF TWO LAGRANGE POLYNOMIALS, WITH LINEAR INTERPOLATION AT TOP' AND BOTTOM OF CAST. CORE STORAGE USED-- 3OK BYTES. AUTHOR-- MARILYNN R. BORKOWSKI.

BUREAU OF COMMERCIAL FISHERIES

TROPICAL ATLANTIC BIOLOGICAL LABORATORY

75 VIRGINIA BEACH DRIVE

MIAMI, FLORIDA 33149 
(COPY ON FILE AT NODC)

INTERPOLATES DEPTH, TEMPERATURE, AND SALINITY AT ISENTROPIC LEVELS. NUOS (NUWR AND ES) PROGRAM FOR THE IBM 1620 REVISED FOR IBM 7074 BY RUDI SAENGER. THERE ARE TWO VERSIONS OF THIS PROGRAM - (IA) STARTING AT SIGMA-T OF FIRST DATA CARD COMPUTING 99 LEVELS, (1B) STARTING AT SIGMA-T 23.00 COMPUTING 50 LEVELS. INPUT CONSISTS OF NODCIS OCEAN STATION DATA CARDS.

COMPUTER SYSTEMS DIVISION

NATIONAL OCEANOGRAPHIC DATA CENTER

WASHINGTON, D. C. 20390

SHIPBOARD SURVEY -- ON-STATION MODE

LANGUAGE - FORTRAN

COMPUTER - IBM 7074

PROCESSES MAGNETIC TAPES MADE ON-STATION TO-- 1 (1) GENERATE A MAGNETIC TAPE OF SELECTED RECORDED DATA IN NUMERIC FORMAT FOR INPUT TO A PIOOTTER PROGRAM IOS NO. 10131 ), (2) COMPUTE SIGMA-T, SPECIFIC VOLUME ANOMALY AND DYNAMIC DEPTH ANOMALY, (3) PRODUCE PRINTER LISTINGS OF THE RECORDED DATA AND THE CORRESPONDING COMPUTED VALUES, USED IN SELECTING STATIONS FOR WHICH DATA IS TO BE PLOTTED. OS NO. 10132 . AUTHOR-- GAY M. BROOK.

NAVIGATIONAL SCIENCE, CODE 5320

NAVAL OCEANOGRAPHIC OFFICE

SUITLAND, MD. 20390

\section{OCEANOGRAPHIC DATA PROGRAM F}

(COPY ON FILE AT NODC)

LAGRANGIAN INTERPOLATIONS AT STANDARD DEPTHS AND COMPUTATION OF SUCH OCEANOGRAPHIC QUANTITIES AS DYNAMIC HEIGHT, THERMOSTERIC ANOMALY, SIGMA-T, SOUND VELOCITY, ETC. ORIGINAL PROGRAM FOR THE IBM 650 BY KILMER AND DUXBURY, 1959 , FOR INTERPOLATION AND CALCULATION OF DYNAMIC HEIGHT (TEXAS A. AND M. TECH. REPORT NO. 59-24T), REVISED NOV 1962 BY NOWLIN. EACH STATION REQUIRES HEADER CARDS TO SPECIFY THE ARRANGEMENT OF THE PRINTED OUTPUT AND FOR ADDITIONAL INFORMATION.

TEXAS A AND M UNIVERSITY

COLLEGE OF GEOSCIENCES

DEPARTMENT OF OCEANOGRAPHY

COLLEGE STATION, TEXAS 77843
LANGUAGE - FORTRAN IV

COMPUTER - IBM 7094

CALCULATES SIGMA-T, DELTA, DELTA-T, POTENTIAL TEMPERATURE, POTENTIAL SIGMA-T, AND POTENTIAL DELTA AT OBSERVED DEPTHS. THE CALCULATION OF POTENTIAL TEMPERATURE IS AN APPROXIMATION SINCE DEPTH IS USED INSTEAD OF PRESSURE. FORMULA USED FOR POTENTIAL TEMPERATURE IS THAT OF FOFONOFF AND FROESE (1958). CALCULATION OF OTHER QUANTITIES IS THE SAME AS IN SUBROUTINE 'SIGMA'. SUBROUTINES NEEDED-- SIGMA.

ROBERT K. SEXTON

NARRAGANSETT MARINE LABORATORY

UNIVERSITY OF RHODE ISLAND

KINGSTON, RHODE ISLAND 0288 I 
UTILIZES OUTPUT FROM PROGRAM 'CARDS' TO CALCULATE DYNAMIC HEIGHTS, GEOSTROPHIC VELOCITIES, TRANSPORTS, AND DELTA VALUES INTERPOLATED AT STANDARD DEPTHS, AS WELL AS POTENTIAL DELTA, AND SIGMA-T AT OBSERVED DEPTHS. CAN ALSO YIELD PUNCHED OUTPUT FOR INPUT TO A PLOTTER ROUTINE. SUBROUTINES NEEDED-- SPEWIT, VEL, MSTRCD, VTR, PDEN, EXTIME, SIGMA, LAINT. DYNHT, HOLES.

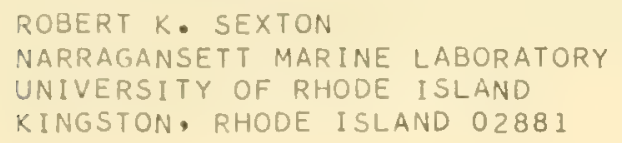

INTEST

LANGUAGE - FORTRAN IV-E COMPUTER - IBM $360 / 50$

GIVEN SERIAL OBSERVATIONS OF TEMPERATURE, SALINITY AND DEPTH, IT COMPUTES DELTA AT OBSERVED DEPTHS AND CREATES AN ARRAY IZSTDI OF STANDARD DEPTHS EVERY $20 \mathrm{M}$ TO $100 \mathrm{M}$, EVERY $100 \mathrm{M}$ TO $800 \mathrm{M}$, AND EVERY $200 \mathrm{M}$ THEREAFTER, AND A CORRESPONDING ARRAY 'SUMDEL' CONTAINING A NUMERICAL INTEGRATION OF DELTA WITH DEPTH, IN DYNAMIC CENTIMETERS. SUBROUTINES-- SIGMAD, DELINT.

ROBERT K. SEXTON

NARRAGANSETT MARINE LABORATORY

UNIVERSITY OF RHODE ISLAND

KINGSTON, RHODE ISLAND 02881

SUBROUTINE COMPUTES THERMOMETRIC DEPTH FROM CORRECTED PROTECTED AND UNPROTECTED THERMOMETER READINGS. AN ESTIMATE OF DEPTH IS OBTAINED BY TAKING 100 TIMES THE DIFFERENCE IN UNPROTECTED AND PROTECTED THERMOMETER READINGS. THIS ESTIMATE IS USED TO CALCULATE A FIRST VALUE FOR MEAN DENSITY, RHO, USING AN EQUATION FROM A POLYNOMIAL FIT OF WUSTIS DATA OF MEAN DENSITY WITH DEPTH IN THE NORTH ATLANTIC ( THERMOMETRIC MEASUREMENT OF DEPTH, BY G. WUST, IN THE HYDROGRAPHIC REVIEW 10, 1933 , TABLE 1, PAGE 34). THIS DENSITY IS USED IN THE EXPRESSION D (METERS) EQUALS (TU-TW/Q * RHO) TO CALCULATE DEPTH. THIS DEPTH IS USEU TO RECALCULATE THE MEAN DENSITY, RHO, AND THE LAST TWO STEPS ITERATED UNTIL SUCCESSIVE CALCULATIONS AGREE TO WITHIN 0.25 METERS.

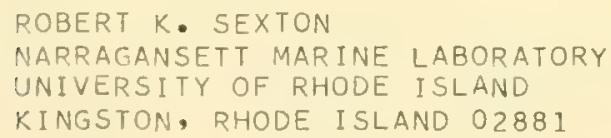

SUBROUTINE PROVIDES LINEAR INTERPOLATION OF AN X VALUE FOR THE GIVEN Y VALUE. IF $Y$ IS OUTSIDE THE LIMITS OF THE Y AXIS, THE CORRESPONDING $X$ END POINT VALUE IS USED, AND THE MESSAGE INDICATOR IS SET TO SHOW THIS.

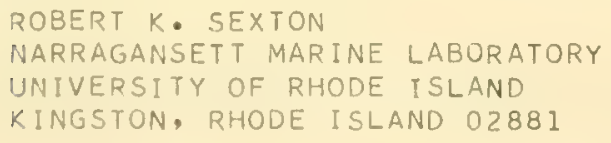


STANDARD DEPTHS.

SUBROUTINES NEEDED-- SIGMAD.

ROBERT K. SEXTON

NARRAGANSETT MARINE LABORATORY

UNIVERSITY OF RHODE ISLAND

KINGSTON, RHODE ISLAND 02881

S IGMA

LANGUAGE - FORTRAN IV-E

COMPUTER - IBM $360 / 50$

SUBROUTINE CALCULATES SIGMA-T, DELTA, IN SITU SPECIFIC VOLUME AND STANDARD WATER COLUMN SPECIFIC VOLUME FROM THE GIVEN CHLORINITY, TEMPERATURE AND DEPTH. THE EQUATIONS USED ARE THOSE CITED BY FOFONOFF IN - THE SEA', VOL. 1, INTERSCIENCE PUBLISHER, N.Y., 1962, M.N. HILI, ED., USING EQUATION (21), PAGE 8, TO COMPUTE SIGMA ZERO, EQUATION (22) AND THE QUANTITIES FOLLOWING EQUATION 124$)$ TO COMPUTE SIGMA-T, AND USING EQUATION (25) AND (26), PAGE 10, TO COMPUTE SPECIFIC VOLUME.

ROBERT K. SEXTON

NARRAGANSETT MARINE LABORATORY

UNIVERSITY OF RHODE ISLAND

KINGSTON, RHODE ISLAND 02881

SIGMAD

LANGUAGE - FORTRAN IV-E

COMPUTER - IBM $360 / 50$

DOUBLE PRECISION VERSION OF 'SIGMA'.

ROBERT K. SEXTON

NARRAGANSETT MARINE LABORATORY

UNIVERSITY OF RHODE ISLAND

KINGSTON, RHODE ISLAND 02881

DYNHT

LANGUAGE - FORTRAN I I

COMPUTER - GE 225

COMPUTES AN ARRAY OF DYNAMIC HEIGHTS (EXPRESSED IN DYNAMIC METERS) FOR SPECIFIED ARRAYS OF PRESSURE AND SPECIFIC VOLUME ANOMALIES. AUTHOR-JACQUELINE WEBSTER.

INFORMATION PROCESSING CENTER

WOODS HOLE OCEANOGRAPHIC INSTITUTION

WOODS HOLE, MASS. 02543

PEN

LANGUAGE - FORTRAN II

COMPUTER - GE 225

COMPUTES POTENTIAL ENERGY ANOMALY, USING THE TRAPEZOIDAL RULE OF INTEGRATION. PEN SUBROUTINE OCCUPIES $130(8)$ OR $88(10)$ LOCATIONS IN MEMORY. AUTHOR-- -JACQUELINE WEBSTER.

INFORMAT ION PROCESSING CENTER

WOODS HOLE OCEANOGRAPHIC INSTITUTION

WOODS HOLE, MASS. 02543

VFREQ

LANGUAGE - FORTRAN II

COMPUTER - GE 225

COMPUTES TABLES OF VAISALA FREQUENCY (RADIANS/SEC.) AND IN SITU DENSITY (GRAMS/CC.), GIVEN TABLES OF DEPTH, TEMPERATURE, AND SALINITY AND

THE LATITUDE OF OBSERVATION. AUTHOR-- H. PERKINS.

INFORMATION PROCESSING CENTER

WOODS HOLE OCEANOGRAPHIC INSTITUTION 
DYNAMIC QUANTITIES. THE INTERPOLATION METHOD TAKES AN AVERAGE OF THE POINTS OBTAINED FROM TWO PARABOLIC FITS. CORE STORAGE NEEDED-- $32 \mathrm{~K}$ WORDS. DOCUMENTATION-- USAGE INSTRUCTIONS• AN OLDER UNIVERSITY OF WASHINGTON PROGRAM 'INTERPOLATION FOR OFFSHORE OCEANOGRAPHIC DATA', IN FORTRAN IV FOR THE IBM 7094, IS IN THE LIBRARY FILE AT THE NODC. THIS INTERPOLATES OCEAN STATION VARIABLES TO STANDARD DEPTHS, USING LAGRANGE SUBROUTINE, CALCULATES ERROR TERMS FOR INTERPOLATIONS, COMPUTES SIGMA-T, SPECIFIC VOLUME ANOMALY, DYNAMIC DEPTH, AND POTENTIAL ENERGY. THE DECK HAS ABOUT 1500 CARDS, INCLUDING TWO FAP SUBROUTINES AND A BINARY EDITOR PROGRAM.

\author{
UNIVERSITY OF WASHINGTON \\ DEPARTMENT OF OCEANOGRAPHY \\ 22A OCEANOGRAPHY TEACHING BLDG. \\ ATTN. MRS. HELLA MACINTOSH \\ SEATTLE, WASH・ 98105
}

INCLUDES CALCULATION OF SIGMA-T AND SPECIFIC VOLUME ANOMALY FOR OBSERVED POINTS, RATTRAY-TYPE LAGRANGE INTERPOLATION AND DYNAMIC DEPTH CALCULATION AT STANDARD DEPTHS.

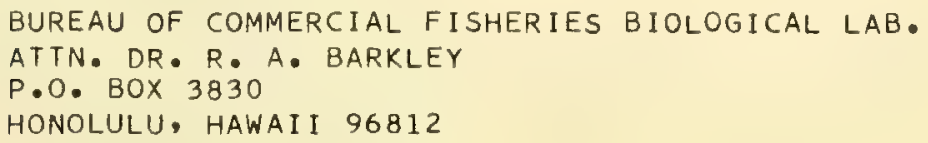

COMPUTES VARIOUS OCEANOGRAPHIC PARAMETERS FROM NODC FORMAT STATION DATA CARDS. OUTPUT IS ON LINE PRINTER. PROGRAM REQUIRES CORE STORAGE OF 12,752 WORDS.

INFORMATION PROCESSING CENTER

ATTN. MARY HUNT

WOODS HOLE OCEANOGRAPHIC INSTITUTION

WOODS HOLE, MASSACHUSETTS 02543

POTEMP, DPOTEM

LANGUAGE - FORTRAN IV-H

(COPY ON FILE AT NODC)

COMPUTER - SDS 5 IGMA 7

SUBROTUINE COMPUTES THE POTENTIAL TEMPERATURE OF SEA WATER AT A GIVEN TEMPERATURE, SALINITY AND PRESSURE USING A FORMULA OF N.P. FOFONOFF AND C. FROESE IN THE P.O.G. MS REPORT SERIES NO. 27. WRITTEN IN FORTRAN II FOR THE GE 225 BY J. WEBSTER. CONVERTED TO FORTRAN IV-H BY M. HUNT (APRIL 1968). DPOTEM IS A FORM OF POTEMP USING DOUBLE PRECISION VARIABLES. STORAGE REQUIREMENTS-- $137(10)$ LOCATIONS FOR POTEMP, $116(10)$ LOCATIONS FOR DPOTEM.

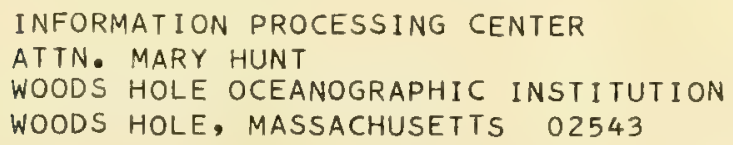

SIGMAT, DSIGMT

LANGUAGE - FORTRAN IV-H COMPUTER - SDS SIGMA 7

SUBROUTINE COMPUTES SIGMA-T FROM TEMPERATURE AND SALINITY BY KNUDSENIS FORMULA REWRITTEN BY FOFONOFF AND TABATA. DSIGMT IS DOUBLE-PRECISION FORM OF SIGMAT. 
SUBROUTINE COMPUTES THE SPECIFIC VOLUME OF SEAWATER AT A GIVEN TEMPERATURE, PRESSURE, SIGMA-O AND SIGMA-T, USING THE FORMULA BY V.W. EKMAN, REWRITTEN BY FOFONOFF AND TABALA (P.0.G. MANUSCRIPT SERIES NO. 25). DSPVOL IS A FORM OF SPVOL USING DOUBLE-PRECISION VARIABLES. 'AIPHA', THE OUTPUT FROM THE SUBROUTINE, IS THE SPECIFIC VOLUME IN MILLIIIITRES PER GRAM. THE USE OF SUBROUTINE SIGMAT WOULD BE REQUIRED BEFURE CALLING SPVOL, AND DSIGMT WOULD BE REQUIRED BEFORE CALLING DSPVOL. STORAGE REQUIREMENTS-- 239(I0) LOCATIONS FOR SPVOL, 204(10) LOCATIONS FOR DSPVOL. WRITTEN IN FORTRAN II FOR THE GE 225 BY $\mathrm{J}$. WEBSTER, CONVERTED TO FORTRAN IV-H BY M. HUNT (APRIL 1968 ).

INFORMATION PROCESSING CENTER

ATTN. MARY HUNT

WOODS HOLE OCEANOGRAPHIC INSTITUTION

WOODS HOLE, MASSACHUSETTS 02543

ATG

CALCULATES ADIABATIC TEMPERATURE GRADIENT FOR SPECIFIED VALUES OF PRESSURE, TEMPERATURE, AND SALINITY, USING AN EMPIRICAL FORMULA DEVELOPED BY N.P. FOFONOFF. (PROGRAM WRITTEN AS SUBROUTINE.)

INFORMATION PROCESSING CENTER

ATTN. MARY HUNT

WOODS HOLE OCEANOGRAPHIC INSTITUTION

WOODS HOLE, MASSACHUSETTS 02543

SUBROUTINE COMPUTES STABILITY FREQUENCY FROM HYDROGRAPHIC STATION DATA, ACCORDING TO A RELATIONSHIP DERIVED BY HESSELBERG AND SVERDRUP.

INFORMATION PROCESSING CENTER

ATTN. MARY HUNT

WOODS HOLE OCEANOGRAPHIC INSTITUTION

WOODS HOLE, MASSACHUSETTS 02543

SUBROUTINE COMPUTES THE SPECIFIC VOLUME ANOMALY, GIVEN THE PRESSURE AND THE SPECIFIC VOLUME, FROM AN EMPIRICAL FORMULA DEVISED BY FOFONOFF AND TABATA.

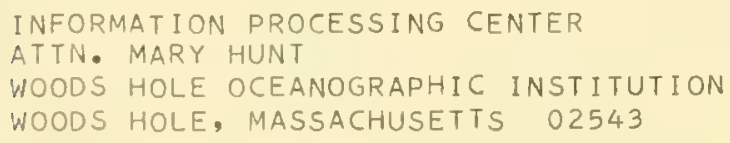


INFORMATION PROCESSING CENTER

ATTN. MARY HUNT

WOODS HOLE OCEANOGRAPHIC INSTITUTION

WOODS HOLE, MASSACHUSETTS 02543

DELTA-ALPHA AND SIGMA-T

LANGUAGE - MAC

COMPUTER - ICT 1301

CALCULATES DELTA-ALPHA AND SIGMA-T AS A FUNCTION OF SALINITY, TEMPERATURE, AND DEPTH. AUTHORS-- A.M. SHIPLEY AND D. SACKS

UNIVERSITY OF CAPE TOWN

OCEANOGRAPHY DEPARTMENT

ATTN. MR. A.M. SHIPLEY

PRIVATE BAG, RONDEBOSCH, C.P.

REPUBLIC OF SOUTH AFRICA

DYNAMIC HEIGHT AND CURRENT DYNAMICS

LANGUAGE - MAD

COMPUTER - IBM 7090

COMPUTES DYNAMIC HEIGHT, VOLUME TRANSPORT, AND NORMAL VELOCITY FOR FRESH WATER.

VINCENT NOBLE

THE UNIVERSITY OF MICHIGAN

GREAT LAKES RESEARCH DIVISION

INSTITUTE OF SCIENCE AND TECHNOLOGY

1077 NORTH UNIVERSITY BUILDING

ANN ARBOR, MICHIGAN 48104

OCEANOGRAPHIC ANALYSIS AND STATION SUMMARY

LANGUAGE - PAL III

COMPUTER - PDP-5, $8 S$

FORMATS AND RECORDS OCEANOGRAPHIC DATA INCLUDING SURFACE ENVIRONMENTAL PHENOMENA, COMPUTES SIGMA-T, THE ANOMALY OF SPECIFIC VOLUME, AND SOUND VELOCITY AT OBSERVED VALUES OF DEPTH-TLMPERATURE-SALINITY. COMPUTES SIGMA-T AND ANOMALY OF SPECIFIC VOLUME FROM SCALED VALUES OF TEMPERATURE AND SALINITY, THE RESULTS OF A LAGRANGIAN INTERPOLATION. DOES A DEPTH INTEGRATION OF ANOMALY OF SPECIFIC VOLUME FROM THE OBSERVED OR SCALED VALUES IN ORDER TO CALCULATE THE DYNAMIC HEIGHT FROM A LEVEL OF NO-MOTION. PRINCIPALLY USED ABOARD OCEANOGRAPHIC VESSEL BY THE FIELD OCEANOGRAPHER IMMEDIATELY AFTER STATION. WRITTEN FOR THE U.S. COAST GUARD BY LT. R.M. OIHAGAN (RET.), DIGITAL EQUIPMENT CORP., MAYNARD, MASS. COPY OF PROGRAM DEPOSITED WITH DECUS. REF. U.S. COAST GUARD OCEANOGRAPHIC MANUSCRIPT IOCEANOGRAPHIC COMPUTER PROGRAMS FOR THE PDP5\%, 15 OCT. 1964 (UNPUBLISHED MANUSCRIPT). PROGRAM REVISED IN 1965.

DIGITAL EQUIPMENT CORPORATION

MAYNARD, MASSACHUSETTS 01754

DISSOLVED OXYGEN AND POTENTIAL TEMPERATURE.

LANGUAGE - PAL III
COMPUTER - PDP-5, $8 S$

CALCULATES DISSOLVED OXYGEN FROM A GIVEN THIOSULPHATE TITER • CALCULATES PERCENT SATURATION OF OXYGEN (FOX'S FORMULAE). CALCULATES POTENTIAL TEMPERATURE. ASR-33 TELEPRINTER INPUT-OUTPUT. PROGRAM PRINCIPALLY USED ABOARD OCEANOGRAPHIC VESSEL. WRITTEN FOR THE U.S. COAST GUARD BY LT. R.M. O'HAGAN (RET.), DIGITAL EQUIPMENT CORP., MAYNARD, MASS. COPY DEPOSITED WITH DECUS.

DIGITAL EQUIPMENT CORPORATION

MAYNARD, MASSACHUSETTS 01754 
INTERPOLATION AT STANDARD DEPTHS OF TEMPERATURE AND SALINITY, SIGMA-T AND THE DYNAMICS COMPUTATIONS.

SCRIPPS INSTITUTION OF OCEANOGRAPHY

LA JOLLA, CALIFORNIA 92037

RADIATION ATTENUATION

LANGUAGE - (NOT GIVEN)

COMPUTER - CDC 1604

COMPUTATION OF THE ATTENUATION COEFFICIENTS FROM SUBMARINE IRRADIANCE MEASUREMENTS.

SCRIPPS INSTITUTION OF OCEANOGRAPHY

LA JOLLA, CALIFORNIA 92037

*-* * SOUND - RAY PATH *-*-*

ACOUSTIC RAY TRACING

LANGUAGE - FORTRAN II

COMPUTER - IBM 7090

(COPY ON FILE AT NODC)

CALCULATES UNDERWATER SOUND PROPAGATION. PROGRAM REQUIRES INPUT WHICH DESCRIBES THE SOURCE, THE FIELD, THE SURFACE AND THE BOTTOM. OUTPUT IS A REPORT ON MAGNETIC TAPE WHICH GIVES RAY PATH, SLOPE, CURVATURE, AND LENGTH. ALSO GIVEN ARE REFLECTION AND EXTREMA STATISTICS, TRAVEL TIME, WAVE FRONT CURVATURE, AND INTENSITY. PROGRAM AND DOCUMENTATION PUBLISHED IN ARTHUR D. LITTLE, INC. TECHNICAL REPORT NO. 1470764. THE A.D. NO. IS AD 605 328. ALSO AVAILABLE FROM THE DEFENSE DOCUMENTATION CENTER.

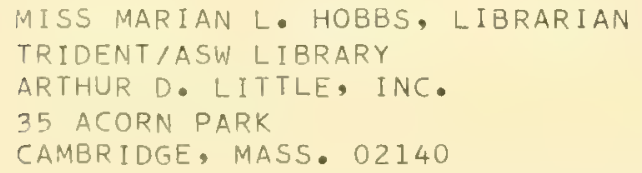

TRLOSS

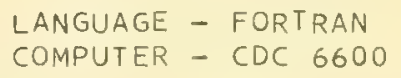

COMPUTES LONG-RANGE TRANSMISSION LOSS BY PROBABILISTIC METHODS, USING A STATISTICAL APPROXIMATION TO RAY-TRACING. INPUT-- PUNCHED CARDS CONTAINING VELOCITY PROFILES, BOTTOM, TOPOGRAPHY (ROUGH) AND TARGET RANGES. OUTPUT-- LISTS OF INTENSITIES (RELATIVE TO SOURCE INTENSITY) AS FUNCTIONS OF DEPTH AT EACH OF THE TARGET RANGES. CORE STORAGE NECESSARY-- $3018 \mathrm{~J} \mathrm{~K}$ WORDS. AUTHOR-- MISS ELLEN WILLIAMS.

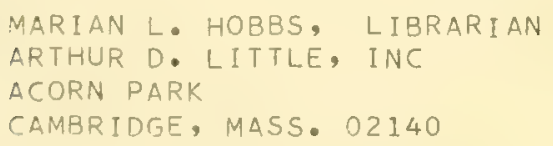

SONAR IN REFRACTIVE WATER

$$
\begin{aligned}
& \text { LANGUAGE - FORTRAN IV } \\
& \text { COMPUTER - UNIVAC } 1108
\end{aligned}
$$

( COPY ON FILE AT NODC)

TRACES SOUND RAYS, COMPUTES REVERBERATION, COMPUTES ACQUISITION LAMINAE (VERTICAL PLANE), IN A LINEAR-GRADIENT OR CONTINUOUS-GRADIENT MEDIUM. CORE STORAGE USED-- APPROX - 30,000 WORDS - SUPERSEDES ALL PREVIOUS VERSIONS OF THE PROGRAM. DOCUMENTED AS NUC TECHNICAL PUBL ICATION NO. 164 (VOL.1, 196 P AND VOL.2, 356 P) 'DIGITAL COMPUTER PROGRAMS FOR ANALYZING ACOUSTIC SEARCH PERFORMANCE IN REFRACTIVE WATERS', NUC PROGRAMS 800000 AND 800001 , BY PHILIP MARSH AND A.B. POYNTER, ORLNANCE SYSTEMS DEPARTMENT, DECEMBER 1969. (DOCUMENTS UNCLASSIFIED BUT TRANS- 
MITTALS CONTROLLED BY NUC.)

NAVAL UNDERSEA RESEARCH AND DEVELOPMENT CENTER

PASADENA LABORATORY

ATTN. PHILIP MARSH

3202 E. FOOTHILL BLVD.

PASADENA, CALIF. 91107

RAY SORT

(COPY ON FILE AT NODC)

SORTS CERTAIN SOUND RAY DATA IFROM TAPE WRITTEN BY THE ISONAR IN RE-

FRACTIVE WATER' PROGRAM) BY DEPTH, INITIAL RAY ANGLE, AND DEPTH-INTER-

SECTION NUMBER. SOURCE PROGRAM HAS 450 INSTRUCTIONS. CORE STORAGE--

ABOUT 31,000 WORDS. DOCUMENTED AS NUC TECHNICAL PUBLICATION NO. 164

( VOL.1, 196 P AND VOL.2, 356 P) IDIGITAL COMPUTER PROGRAMS FOR ANALYZING ACOUSTIC SEARCH PERFORMANCE IN REFRACTIVE WATERS, NUC PROGRAMS 800000 AND 800001 , BY PHILIP MARSH AND A.B. POYNTER, ORDNANCE SYSTEMS DEPARTMENT, DECEMBER 1969. (DOCUMENTS UNCLASSIFIED BUT TRANSMITTAISS CONTROLLED BY NUC. I

NAVAL UNDERSEA RESEARCH AND DEVELOPMENT CENTER

PASADENA LABORATORY

ATTN. PHILIP MARSH

3202 E. FOOTHILL 8LVD.

PASADENA, CALIF. 91107

RAYMOR

LANGUAGE - FORTRAN $V$

COMPUTER - UNIVAC 1108

( COPY ON FILE AT NODC)

COMPUTES RAYLEIGH-MORSE BOTTOM REFLECTION COEFFICIENTS, ALSO PHASE

CHANGES OF THE REFLECTED AND TRANSMITTED ACOUSTIC WAVE. AUTHOR--

J.C. REEVES.

NAVAL UNDERSEA RESEARCH AND DEVELOPMENT CENTER

PASADENA LABORATORY

3202 E. FOOTHILL BOULEVARD

PASADENA, CALIFORNIA 91107

NEWF I T

LANGUAGE - FORTRAN $V$

COMPUTER - UNIVAC 1108

ICOPY ON FILE AT NODC)

FITS A VELOCITY PROFILE WITH A SERIES OF CURVE SEGMENTS HAVING CONTINUOUS FIRST DERIVATIVES AT POINTS OF INTERSECTION. OUTPUT-- PRINTED LISTINGS OF ORIGINAL DATA, FITTED DATA, AND COEFFICIENTS OF CURVE SEGMENTS - ALSO CARDS FOR INPUT TO 'SONAR IN REFRACTIVE WATER' PROGRAM. NEWFIT IS THE MAIN ROUTINE OF THE NEW CURVE FITTING PROGRAM. A REPORT AP-PROG-C-8070 (FEB 1968, 98 P), BY MELVIN O. BROWN, DOCUMENTS THE DETAILS OF THE ENTIRE PROGRAM. CORE STORAGE NECESSARY -- APPROX • 25,000 WORDS, I INCLUDING LIBRARY AND SYSTEM ROUTINES.

NAVAL UNDERSEA RESEARCH AND DEVELOPMENT CENTER

PASADENA LABORATORY

ATTN. PHILIP MARSH

3202 E. FOOTHILL BLVD.

PASADENA, CALIF. 91107

\section{PATTERN FUNCTION CALCULATIONS}

$$
\begin{aligned}
& \text { LANGUAGE - FORTRAN IV } \\
& \text { COMPUTER - UNIVAC } 1108
\end{aligned}
$$

(COPY ON FILE AT NODC)

COMPUTES TRANSDUCER PATTERN FUNCTIONS NEEDED IN THE SONAR EQUATIONS WHEN ESTIMATING SEARCH PERFORMANCEE OF ACOUSTIC TORPEDOES. THE DESIRED PARAMETERS INCLUDE THE TRANSMIT AND RECEIVE DIRECTIVITY INDEXES AND THE VOLUME AND BOUNDARY REVERBERATION INDEXES. IN A VEHICLE EMPLOYED IN CIRCULAR SEARCH, THE REVERBERATION INDEXES ARE FUNCTIONS OF TURN RATE AND ELAPSED TIME IN THE PING CYCLE. THE OUTPUT IS USED OY THE 
I SONAR IN REFRACTIVE WATERI PROGRAM. THEORY, FLOW CHARTS, AND IISTING GIVEN IN REPORT AP-PROG-C-7035 (APR 1967, 80 P), BY HERBERT S. KAPLAN.

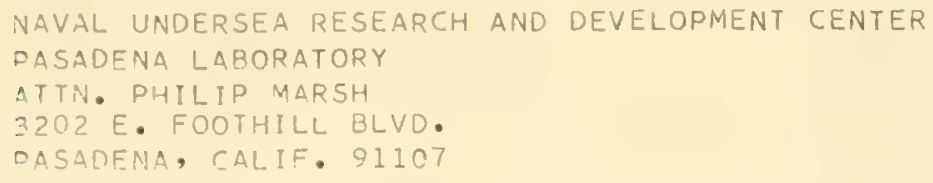

DESCRIBES ACOUSTIC PATHS OF UP TO 1000 RAYS AS THEY PROGRESS THROUGH THE OCEAN FROM A POINT SOURCE AT ARBITRARY RANGE AND DEPTH. ALI. RAYS ARE TRACED SIMULTANEOUSLY IN ONE PASS THROUGH THE VELOCITY FIELD. AS THE RAYS ARE TRACED SEVERAL TYPES OF INTENSITY CALCULATIONS ARE PERFORMED AND A MULTIPLOT OF RAYS CONSTRUCTED. BASIC INPUT CONSISTS OF A MAGNETIC TAPE GENERATED BY THE 'GENERAL VELOCITY FIELD' PROGRAM. OUTPUT-- RANGES, DEPTHS, TRAVEL TIME, SINE OF ANGLE, NUMBER OF TURNING POINTS, NUMBER OF SURFACE AND BOTTOM HITS, AND SIGNAL STRENGTH OF EACH RAY AT RANGES SPECIFIED BY THE USER. ALSO, TYPE I, I I, II I INTENSITIES, TRANSMISSION LOSS AND TRANSMISSION ANOMALY. BASIC IDEAS CONTAINED IN HUDSON LAB TECHNICAL REPORT NO. 150 (1968). PROGRAM DOCUMENTATION FORTHCOMING.

J. J. CORNYN, CODE 8140

ACOUSTICS DIVISION

NAVAL RESEARCH LABORATORY

WASHINGTON, D. C. 20390

RAY TRACING

LANGUAGE - FORTRAN IV

COMPUTER - CDC 3800

CALCULATES RAY THEORY, ARRIVALS AND INTENSITIES AT A LARGE NUMBER OF RECEIVERS. INPUT-- VELOCITY PROFILE EITHER AS V VS. Z OR T,S VS.Z. ALSO SOURCE AND RECEIVER DEPTHS, INITIAL RAY ANGLES AND RECEIVER RANGES, BEAM PATTERNS (IF ANY), BOTTOM LOSS TABLE, SURFACE LOSS, FREQUENCY. OUTPUT - LISTINGS AND PLOTS. EITHER COHERENT OR RANDOM PHASE ARRIVAL SUMS ARE AVAILABLE.

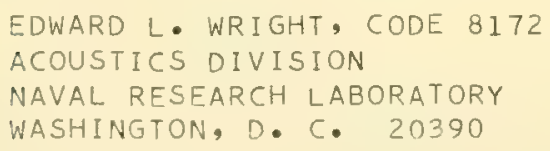

CALCULATES PATHS OF ACOUSTIC RAYS FROM A POINT SOURCE IN THE OCEAN, THROUGH A SERIES OF SOUND SPEED PROFILES, ALONG WITH THEIR TRAVEL TIMES AND TRANSMISSION LOSSES. REFLECTIONS OF THE RAYS FROM A LINEAR SEGMENTED BOTTOM ARE CALCULATED. COMPUTES CLOSED FORM PATH ELEMENTS BETWEEN LAYER BOUNDARIES IN THE PROFILE. RAYS ARE TRACED SEQUENTIALLY. PROGRAM WILL BE DOCUMENTED IN A FORTHCOMING REPORT.

E. B. WRIGHT

CODE 8177, ACOUSTICS DIVISION

NAVAL RESEARCH LABORATORY

WASHINGTON, D. C. 20390 
TION OF ARRIVALS. OUTPUT- TRANSMISSION LOSS AS A FUNCTION OF RANGE FOR UP TO 20 RECEIVER DEPTHS AND UP TO 200 RANGE INCREMENTS.

E. B. WRIGHT

CODE 8177 , ACOUSTICS DIVISION

NAVAL RESEARCH LABORATORY

WASHINGTON, D. C. 20390

RAY TRACING

$\begin{aligned} \text { LANGUAGE - } & \text { FORTRAN AND } \\ & \text { KLERER-MAY } \\ & \text { USER LANG. } \\ \text { COMPUTER - } & \text { (NOT GIVEN) }\end{aligned}$

( COPY ON FILE AT NODC)

A SERIES OF PROGRAMS FOR THE CALCULATION OF THE ACOUSTICAL FIELD IN LONG-RANGE (SEVERAL HUNDRED TO SEVERAL THOUSAND MILES), LOW FREQUENCY UNDERWATER SOUND PROPAGATION IN THE DEEP OCEAN. INVOLVES THE CALCULATION OF RAY TRAJECTORIES, AND INTENSITY CALCULATIONS THAT ARE BASED ON THE MAPPING OF RAY DENSITIES INTO THE FAR ACOUSTICAL FIELD. I/P FOR-' MAT FROM NODC DATA TAPES OR FLEET. NUMERICAL WEATHER CENTRAL CARDS. REF. 'THE HUDSON LABORATORIES RAY TRACING PROGRAM! (JUNE 1968, 363 P.) AUTHORS-- H. DAVIS, H. FLEMING, W.A. HARDY, R. MININGHAM, AND S. ROSENBAUM.

RAYTR (RAY-TRACING)

LANGUAGE - FORTRAN IV COMPUTER - IBM $360 / 44$

TRACES SOUND RAY PATHS IN A LAYERED FLUID MEDIUM. TRAVEL-TIMES, RELATIVE TRAVEL-TIMES, TOTAL PATH LENGTHS ALONG THE RAY, INTENSITIES AND THE COORDINATES OF FOCI ARE ALSO COMPUTED. THE PROGRAM IS SIMILAR IN MANY RESPECTS TO H.W. DOSSO, ET AL IRAY TRACING WITH A PB-250', TECH. MEMO. 63-11 (UNPUBLISHED). THE NUMBER OF ALLOWED SOUND-SPEED VS DEPTH AND BOTTOM PROFILE DATA ENTRIES HAS BEEN INCREASED FROM 32 TO 360. AUTHOR-- R.W. DE JEAN. DESCRIBED IN TECHNICAL MEMO. 68-5, FED 1968.

DEFENCE RESEARCH ESTABLISHMENT PACIFIC

VICTORIA, B. C. CANADA

ORD 1 (OLMSTED RAY DIAGRAM PROGRAM NO. 1 )

\author{
LANGUAGE - FORTRAN \\ COMPUTER - GE 225
}

CONSTRUCTS (OPTICAL/ACOUSTIC) RAYS IN A MEDIUM WHERE THE VELOCITY OF LIGHT/SOUND VARIES CONTINUOUSLY WITH ONE COORDINATE (DEPTH). THE RAYS ARE CONFINED TO A RANGE-DEPTH PLANE OF FINITE DEPTH (A LAYER) AND MUST ORIGINATE FROM A SOURCE PLACED AT ANY DEPTH IN THE LAYER AND AT ANGLES OF INCIDENCE GREATER THAN O AND LESS THAN 180 DEG. WHEN A RAY REACHES A VERTEX IOF REFRACTION OR REFLECTION) THE REMAINDER OF THE RAY IS CONSTRUCTED BY SYMMETRY AND PERIODIC EXTENSION. POINTS ARE THEN COMPUTED ALONG THESE RAYS AT INTERVALS OF EQUAL RANGE. AUTHOR-- COERT OLMSTED, FEB. 1965 .

WOODS HOLE OCEANOGRAPHIC INSTITUTION

WOODS HOLE, MASS. 02543

ORD 2 (OLMSTED RAY DIAGRAM PROGRAM NO. 2)

LANGUAGE - FORTRAN

COMPUTER - GE 225

SERVES THE SAME PURPOSE AS ORD I EXCEPT THAT THE OUTPUT POINTS ARE AT EQUAL TIME INCREMENTS RATHER THAN AT EQUAL RANGE INCREMENTS AND THUS, WHEN PLOTTED, WILL ENABLE ONE TO TRACE WAVE FRONTS AS WELL AS RAYS. THERE IS NO SYMMETRICAL OR PERIODIC EXTENSION. THE RAY PATH IS COMPUTED LOCALLY ALL THE WAY OUT TO MAXIMUM RANGE. AUTHOR-- COERT OLMSTED, FEB. 1965 . 
PRESENTS A SOLUTION FOR THE RAYLEIGH REFLECTION COEFFICIENT WITH A FOUR LAYER MODEL. OS NO. 20118. AUTHOR-- M.E. MYERS.

COMPUTER DEPARTMENT, CODE 0831

NAVAL OCEANOGRAPHIC OFFICE

SUITLAND, MD. 20390

CRITICAL ACOUSTIC RATIO

LANGUAGE - FORTRAN

COMPUTER - IBM 7074

DETERMINATION OF CRITICAL RATIO OF TRIGONOMETRIC FUNCTIONS OF ACOUSTIC

ANGLES INVOLVED IN CONNECTION WITH THE CONVERGENCE INTERVAL FOR A 3LAYER MODEL OF THE OCEAN. OS NO. 53483. AUTHOR-- C.M. WINGER.

OCEANOGRAPHIC PREDICTION DIV., CODE 3400

NAVAL OCEANOGRAPHIC OFFICE

SUITLAND, MD. 20390

RAY PATH

LANGUAGE - FORTRAN

(COPY ON FILE AT NODC)

COMPUTER - IBM 7074

COMPUTES RANGES AND TRAVEL TIMES FOR SOUND RAYS. OS NO. 53810 . AUTHOR

L.W. CISNEY.

EXPLORATORY OCEANOGRAPHY DIV, CODE 7200

NAVAL OCEANOGRAPHIC OFFICE

SUITLAND, MD. 20390

BOTTOM REFLECTION ANALYSIS

LANGUAGE - FORTRAN

( COPY ON FILE AT NODC)

COMPUTER - IBM 7074

DETERMINES ENERGY LEVEL OF SOUND SOURCES AT CERTAIN DISCRETE FREQUENCIES BY MEANS OF HARMONIC ANALYSIS. OS NO. 53806. AUTHOR-- L. W. CISNEY.

EXPLORATORY OCEANOGRAPHY DIV., CODE 7200

NAVAL OCEANOGRAPHIC OFFICE

SUITLAND, MD. 20390

( COPY ON FILE AT NODC)

COMPUTES RANGES TO THE FIRST CONVERGENCE ZONE. THE WIDTH OF THE

RESWEPT AND INSONIFIED ZONES AND THE RELIABLE ACOUSTIC PATH RANGE ARE ALSO COMPUTED. IN ADDITION, LAYER DEPTH, CHANNEL DEPTH, OPTIMUM DEPTH, BOTTOM VELOCITY, AND DEPTH EXCESS ARE EXTRACTED AND LISTED

IN THE OUTPUT. INPUT EITHER CARD OR TAPE. OS NO. 53334 (RESTRICTED) AUTHOR-- R. BUTTERWORTH.

OCEANOGRAPHIC ANALYSIS DIV., CODE 3300

NAVAL OCEANOGRAPHIC OFFICE

SUITLAND, MD. 20390

\section{LIGHT AND SOUND INSTRUCTION D}

LANGUAGE - FORTRAN
COMPUTER - IBM 7074

(COPY ON FILE AT NODC)

COMPUTES THE CONVERGENCE ZONE PARAMETERS USING THE $V(X)$ METHOU (EQUA-

TIONS OF DONALD COLE), BY ONE-DEGREE QUADRANGLE, BY MONTH AND BY SEASON. AUTHOR-- M.C. CHURCH. 
(COPY ON FILE AT NODC)

COMPUTES HORIZONTAL RANGE, TRAVEL TIME, AND SPREADING LOSS THROUGH A MEDIUM CONSISTING OF LAYERS OF CONSTANT VELOCITY GRADIENT (THE VI $X$ ) METHOD OF DONALD COLE). A PRINTED OUTPUT CONTAINS LAYERED INFORMATION. OPTION TO WRITE A PLOTTER TAPE FOR USE ON THE EAI 3440 DIGITAL PLOTTER. REF. USL TECH. MEMORANDUM NO. 907-78-66 (APRIL, 1966)

PAULINE ONYX

NAVY UNDERWATER SOUND LABORATORY, BLDG. 80

FORT TRUMBULL, NEW LONDON, CONN. 06320

\section{BOTTOM REFLECTIVITY}

LANGUAGE - FORTRAN II
COMPUTER - IBM 704

(COPY ON FILE AT NODC)

USL PROGRAM NO. 0289. COMPUTES THREE ACOUSTIC REFLECTION COEFFICIENTS AS A FUNCTION OF INCIDENT ANGLE AND FREQUENCY. THE PROGRAM ACCOUNTS FOR DIFFERENCE IN PATH LENGTH, DEPTH OF SOURCE AND RECEIVERS, WATER, BOTTOM SLOPE, VELOCITY GRADIENT AND RECORDED TRAVEL TIME. REF. USL TECH. MEMORANDUMS NOS - 913-4-65 AND 907-144-65. THE LATTER REPORT ALSO SERVES TO DOCUMENT A SUPPLEMENTAL COMPUTER PROGRAM (USL NO. 0427 , IN FORTRAN, FOR COMPUTING MEANS AND STANDARD DEVIATIONS OF THE THREE REFLECTION COEFFICIENTS.

R. WHITTAKER

NAVY UNDERWATER SOUND LABORATORY, BLDG. 80

FORT TRUMBULL, NEW LONDON, CONN. 06320

TWO DIMENSIONAL RAY TRACE

DESCRIBES THE PATH OF SOUND EMITTED FROM A POINT SOURCE AS IT PROGRESSES THROUGH THE OCEAN IN ONE HORIZONTAL DIRECTION, TAKING INTO CONSIDERATION BOTH HORIZONTAL AND VERTICAL VARIATION IN THE SOUND VELOCITY OF THE OCEAN. ONE PATH IS TRACED FOR EACH SPECIFIED INITIAL ANGLE FROM THE HORIZONTAL. BEHAVIOR OF RAY PATH IS CONTROLLED BY SOUND VELOCITY GRADIENTS - CORRECTION FOR EARTH CURVATURE IS ADDED. OUTPUT IS A PRINTED LIST AND ALSO IN BINARY FORMAT SUITABLE FOR ADAPTATION TO A PLOTTER. DIRECT INQUIRIES FOR INFORMATION TO--

COMMANDING OFFICER

FLEET NUMERICAL WEATHER CENTRAL

NAVAL POSTGRADUATE SCHOOL

MONTEREY, CALIFORNIA 93940

THESIS3 (SONOBUOY FIXING ERROR)

LANGUAGE - FORTRAN

COMPUTER - (NOT GIVEN)

CALCULATES THE EFFECTS OF HORIZONTAL VELOCITY GRADIENTS IN SEA WATER WHEN OBTAINING A FIX ON A TARGET BY TWO PASSIVE DIRECTIONAL SENSORS. THESIS BY JAMES W. PIGMAN (MAY 1966).

NAVAL POSTGRADUATE SCHOOL

MONTEREY, CALIFORNIA 93940

NEAR-FIELD ARRAY TESTING

LANGUAGE - FORTRAN

COMPUTER - PDP- 8

PROGRAM INVESTIGATES THEORETICALLY THE EFFECT OF IRREGULARITIES IN THE 
POSITIONS OF TRANSDUCER ELEMENTS IN AN ACOUSTIC INEAR-FIELD' ARRAY. REPORT NO. NRL-6728 (MAY $1968,40 P$ ) BY GERALD A. SABIN. DDC NO. IS $A C-A 6 ?-+40^{\circ}$.

UNDERWATER SOUND REFERENCE DIV. NAVAL RESEARCH LABORATORY

ORLANDO, FLORIDA

*-*-* SOUND - NORMAL MODES *-*-*

NORMAL MODE SOLUTIONS FOR SOUND SPEED PROFILES

LANGUAGE - FORTRAN IV COMPUTER - CDC 3800

PROVIDES A NORMAL MODE SOLUTION OF THE WAVE EQUATION WITH THE SOUND SPEED PROFILE FOR THE MEDIUM REPRESENTED BY A SET OF DISCRETE VALUES. THE SEA BOTTOM IS ASSUMED TO BE A SEMI-INFINITE FLUID, SPECIFIED BY A CONSTANT DENSITY AND A CONSTANT SPEED OF SOUND AND WITH NO ATTENUATION. THE INTERFACE BETWEEN THE WATER COLUMN AND THE BOTTOM IS FLAT AND LEVEL. USER SELECTS THE MAXIMUM NUMBER OF MODES DESIRED. OUTPUT- THE NORMALIZED EIGENFUNCTIONS OR MODE SHAPES ARE OBTAINED FROM THE EIGENVALUES AND PLOTTED. THE GROUP VELOCITY CHARACTERISTIC IS OBTAINED OVER A RANGE OF FREQUENCIES AND TABULATED. PROPAGATION LOSS IS PLOTTED AS A FUNCTION OF RANGE. DOCUMENTATION WILL BE IN A FORTHCOMING NRL REPORT.

JOHN CYBULSKI

CODE 8177, ACOUSTICS DIVISION

NAVAL RESEARCH LABORATORY

WASHINGTON, D. C. 20390

PROPAGATION LOSS - NORMAL MODES

LANGUAGE - FORTRAN

COMPUTER - CDC 3800

CALCULATES UNDERWATER SOUND PROPAGATION IN A HORIZONTALLY STRATIFIED MEDIUM. THE PROGRAM CALCULATES A SET OF HORIZONTAL PHASE VELOCITIES FOR THE NORMAL MODES AND THEN SERIES THE MODE AMPLITUDE FUNCTIONS TO FIND THE SOUND LEVELS. INPUT - SOUND VELOCITY PROFILE, SOURCE DEPTH, POSITION OF RECEIVERS IN RANGE AND DEPTH, SURFACE LOSS, AND BOTTOM LOSS TABLE. OUTPUT-- PROPAGATION LOSS AT THE VARIOUS RECEIVERS. PROCEDURE-- APPROXIMATE VALUES OF THE HORIZONTAL PHASE VELOCITY ARE CALCULATED USING RAY THEORY. EXACT VALUES ARE FOUND BY ITERATING IN THE COMPLEX PLANE. SOUND INTENSITIES ARE CALCULATED BY FORMING THE SERIES OF NORMAL AMPLITUDE FUNCTIONS - DOCUMENTATION-- FORTHCOMING NRL REPORT

DR. H. P. BUCKER, JR.

CODE 8170

NAVAL RESEARCH LABORATORY

WASHINGTON, D. C, 20390

$$
\text { **** SOUND - SPEED COMPUTATIONS *-*-* }
$$

\section{SOUND VELOCITY}

(COPY ON FILE AT NODC)

COMPUTES SOUND VELOCITY USING WILSON'S EQUATIONS. OUTPUT CARDS HAVE

VELOCITY OF SOUND IN METERS/SEC, PRESSURE IN KG/SQ-CM, SIGMA-T, IN

ADDITION TO INPUT STATION DATA AND IDENTIFICATION. 
( COPY ON FILE AT NODC)

CORRECTS ECHO SOUNDER READINGS BY COMPUTING ACTUAL TRAVEL TIME FROM A LINEAR SEGMENT VELOCITY PROFILE. INPUT-- DEPTH VS. VELOCITY POINTS ON CARDS. OUTPUT IS PRINTED LIST OF ACTUAL DEPTHS, FATHOMETER DEPTHS AND CORRECTIONS (FATHOMS). A SUBROUTINE FOR THE CALCOMP PLOTS DIFFERENCES VS. ECHO SOUNDER DEPTHS. CORE STORAGE USED-- 4100 .

COMMANDER

NAVAL UNDERSEA RESEARCH AND DEVELOPMENT CENTER

ATTN. D. F. GORDON

SAN DIEGO, CALIFORNIA 92132

GENERAL VELOCITY FIELD

\author{
LANGUAGE - FORTRAN-63 \\ COMPUTER - CDC 3800 , \\ DRUM SCOPE
}

GIVEN A SERIES OF INCOMPLETE VELOCITY PROFILES ALONG A RANGE TRACK THE PROGRAM EXTRAPOLATES THE DEEP PROFILES TO THE BOTTOM USING WILSONIS EQUATION AND INTERPOLATES BETWEEN THE DEEP PROFILES IN ORDER TO EXTEND THE SHALLOW PROFILES. THE RESULT IS A COMPLETE DESCRIPTION OF THE VELOCITY FIELD OVER THE RANGE-DEPTH PLANE. OUTPUT FROM PROGRAM INCLUDES-- VELOCITY, GRADIENT, AND CURVATURE AT DEPTHS AND RANGES SPECIFIED BY USER, A CALCOMP CONTOUR PLOT OF SPECIFIED VELOCITY FIELD, AND A 3-DIMENSIONAL PLOT OF VELOCITY VS. RANGE AND DEPTH. STORAGE NECESSARY - 117,450 OCTAL WORDS OF CORE AND 2 CDC-863 DRUMS.

J. J. CORNYN, CODE 8140

ACOUSTICS DIVISION

NAVAL RESEARCH LABORATORY, WASHINGTON, D.C. 20390

SVLIM

LANGUAGE - FORTRAN II

COMPUTER - CDC 3100

(COPY ON FILE AT NODC)

EXAMPLE OF 'LIMITS' RETRIEVAL FUNCTIONS USED TO EXTRACT SOUND VELOCITY PROFILES. THE PROGRAM READS CONTROL CARDS SPECIFYING GEOGRAPHICAL AND SEASONAL LIMITS OF INTEREST, SCANS A COMPACTED NODC FORMAT FILE FOR OCEAN STATIONS FALLING WITHIN THE SELECTED LIMITS, CONVERTS THE PROFILE FROM METERS/SEC TO FEET/SEC AND PRINTS THE PROFILE. REF. INFORMAL REPORT IR NO. 69-59, JULY 1969. AUTHOR-- WALT YERGEN, EXPLORATORY OCEANOGRAPHY DIVISION, CODE 7240. FURTHER INFORMATION MAY BE OBTAINED FROM THE DISSEMINATION DEPARTMENT CODE 44, OR THE AUTHOR.

NAVAL OCEANOGRAPHIC OFFICE SUITLAND, MARYLAND 20390

DETERMINATION OF POSSIBLE MAGNITUTE OF

LANGUAGE - FORTRAN

ERROR IN VERTICAL SOUND VELOCITY

COMPUTER - IBM 7074

(COPY ON FILE AT NODC)

PROGRAM REQUESTED BY THE COAST AND GEODETIC SURVEY TO CORRECT FATHOMETER READINGS. PROVIDES-- (I) HARMONIC MEAN OF SOUND VELOCITY IN MI SEC AT CHOSEN DEPTHS (2) MEAN VERTICAL SV AT ABOVE DEPTHS WITHIN ONE MARSDEN SQ. (3) VARIANCE OF 2 (4) DIFFERENCE BETWEEN STANDARD AND COMPUTED SV, TESTED AGAINST GIVEN ALLOWABLE ERROR VALUES (5) NUMBER OF STATIONS USED AT EACH DEPTH WITHIN EACH MARSDEN SQ. INPUT MUST BE IN NODC FORMAT TAPE, ZONE-EDITED, IN DEPTH SEQUENCE AND SORTED ON MARSDEN SQUARES. AUTHOR-- RUDI SAENGER. OS NO. 52203.

COMPUTER SYSTEMS DIVISION

NATIONAL OCEANOGRAPHIC DATA CENTER

WASHINGTON, D. C. 20390 
COMPUTES THE HARMONIC MEAN SOUND VELOCITY, TRAVEL TIME, AND CORRECTION RATIO AT 1OO-FATHOM DEPTH INTERVALS BY ONE-DEGREE SQUARE. OS NO. -

20111. AUTHOR-- M.C. CHURCH.

COMPUTER DEPARTMENT, CODE 083

NAVAL OCEANOGRAPHIC OFFICE

SUITLAND, MD. 20390

VELOCITY'OF SOUND IN SEA WATER

LANGUAGE - FORTRAN

(COPY ON FILE AT NODC)

COMPUTES ONE PAGE AT A TIME FOR A GIVEN DEPTH AND A GIVEN SET OF 10

SALINITIES AND TEMPERATURES. A TABLE OF PRESSURES IS READ IN AND CONVERTED TO DEPTHS. USES LATER VERSION UF WILSON'S FORMULA FOUIND IN THE JASA VOL. 32 NO. $10(1960)$.

ESSA, COAST AND GEODETIC SURVEY

WASHINGTON SCIENCE CENTER, BLDG. 2

ROCKVILLE, MD. 20852

WATERVEL

$\begin{aligned} \text { LANGUAGE - } & \text { FORTRAN AND } \\ & \text { BINARY }\end{aligned}$

( COPY ON FILE AT NODC)

COMPUTER - (NOT GIVEN)

COMPUTES SOUND VELOCITY AFTER WILSON $(1960-2)$, SOUNDING VELOCITY, RE-

FLECTION TIME. VALUES INTERPOLATED FROM STANDARD DEPTHS. UNITS CON-

VERSION ENGLISH TO METRIC. AUTHOR-- HELEN KIRK.

SCRIPPS INSTITUTION OF OCEANOGRAPHY

ATTN. G.G. SHOR

LA JOLLA, CALIF. 92038

FUNCTION SDVEL

(COPY ON FILE AT NODC)

SUBPROGRAM COMPUTES SOUND VELOCITY IN SEA WATER FROM TEMPERATURE, SALINITY AND PRESSURE USING WILSON'S FORMULAE. A CONVERSION OF PRESSURE IS MADE FROM NEWTONS/SQ METRE TO KGF/CM SQ.

NATIONAL INSTITUTE OF OCEANOGRAPHY

WORMLEY, GODALMING, SURREY

ENGLAND

SOUND VELOCITY IN OCEAN WATER

LANGUAGE - FORTRAN I I

COMPUTER - IBM 704

(COPY ON FILE AT NODC)

USL PROGRAM NO. 0240. COMPUTES SOUND VELOCITY AS A FUNCTION UF DEPTH, TEMPERATURE, SAL INITY AND LATITUDE. EQUATIONS USED WERE OBTAINED FROM AN NEL PUBLICATION (M.A. PEDERSEN, ET AL, 1962). A PRINTED OUTPUT HAS THE INPUT PARAMETERS AND THE COMPUTED VALUES OF SOUND VELOCITY, PRESSURE, AND DENSITY (RHO) FOR EACH DEPTH. REF. USL TECH. MEMORANDUM NO. 907-94-66 (MAY, 1966).

M. J. GOLDSTEIN

NAVY UNDERWATER SOUND LABORATORY, BLDG. 80

FORT TRUMBULL, NEW LONDON, CONN. 06320 
CORRECTS OBSERVED DEPTHS FOR LATITUDINAL AND LONGITUDINAL VARIATION IN SOUNDING VELOCITY. SOUNDING VELOCITIES CALCULATED BY NODC ARE ENTERED INTO STORAGE AS A LINEAR ARRAY. OBSERVED LATITUDE, LONGITUDE, AND

DEPTH ARE ENTERED INTO THE TABLE AS SEARCH PARAMETERS, AND A THREE-DIMENSIONAL LINEAR INTERPOLATION IS PERFORMED TO OBTAIN AN APPROPRIATE VALUE FOR SOUNDING VELOCITY. THIS IS APPLIED TO THE OBSERVED DEPTH. AN ITERATION ROUTINE REFINES THE CORRECTED DEPTH TO WITHIN A PREDETERMINED ERROR. THE INPUT IS VIA PUNCHED CARDS AND A PRINTED OUTPUT IS PRODUCED. ESTIMATED RUNNING TIME- 0.04 SECONDS PER DATA ENTRY. AUTHOR-- WILLIAM ANIKOUCHINE, JORG, ESSA.

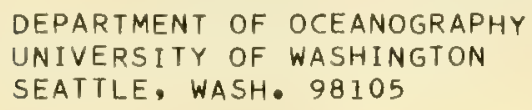

AN/UYK-1 SOUND VELOCITY

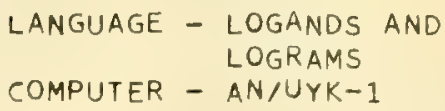

COMPUTES SOUND VELOCITY BY TWO DIFFERENT MEANS FOR COMPARISON WITH THE SOUND VELOCIMETER VALUE OBTAINED THROUGH BISSETT-BERMAN SYSTEM. ALSO COMPUTES PRESSURE, MEAN, VARIANCE, STANDARD DEVIATION, SIGMA-T, SPECIFIC VOLUME, SPECIFIC VOLUME ANOMALY, AND DYNAMIC HEIGHT ANOMALY. OS NO. 20154. AUTHOR $\rightarrow$ O.A. SMITH.

COMPUTER DEPARTMENT, CODE 0831

NAVAL OCEANOGRAPHIC OFFICE

SUITLAND, MD. 20390

VELOCITY OF SOUND

LANGUAGE - MAC

COMPUTER - ICT 1301

CALCULATION OF VELOCITY OF SOUND IN SEA WATER, USING WILSON'S EQUATION. (A MAC ROUTINE WAS ALSO WRITTEN FOR THE CALCULATION OF PRESSURE IN DECI-BARSI AUTHORS-- A.M. SHIPLEY AND D. SACKS.

UNIVERSITY OF CAPE TOWN

OCEANOGRAPHY DEPARTMENT

ATTN. MR. A.M. SHIPLEY

PRIVATE BAG, RONDEBOSCH, C.P.

REPUBLIC OF SOUTH AFRICA

SONVEL

LANGUAGE - FORTRAN I $V-\mathrm{H}$

COMPUTER - SDS SIGMA 7

SUBROUTINE COMPUTES THE SPEED OF SOUND IN SEA WATER FROM THE TEMPERATURE, SALINITY AND PRESSURE ACCORDING TO W.D. WILSON'S FORMULAS. AN EARLIER VERSION WAS WRITTEN BY JACQUELINE WEBSTER IN FORTRAN II FOR THE GE 225 .

INFORMATION PROCESSING CENTER

ATTN. MARY HUNT

WOODS HOLE OCEANOGRAPHIC INSTITUTION

WOODS HOLE, MASSACHUSETTS 02543

*-* * TIDES, AStRONOMICAL $\quad *-*-*$

HARMONIC ANALYSIS OF TIDAL DATA

LANGUAGE - FORTRAN IV

(COPY ON FILE AT NODC)

COMPUTER - CDC 6600

THE PROGRAM GENERATES A VARIABLE LENGTH SINE TABLE IN FIVE QUADRANTS 
AND THE INDEPENDENT VARIABLES WHICH ARE FUNCTIONS OF TIME ARE EXTRACTED FROM THIS TABLE. THE LEAST SQUARES METHOD IS EMPLOYED AND THE HARMONIC CONSTANTS ARE DERIVED BY THE USE OF A MULTIPLE CORRELATION

SCREENING PROCESS WHICH CAN BE TERMINATED WHEN THE REGRESSION EQUATION CONTAINS A SPECIFIED NUMBER OF TERMS OR WHEN THE NEXT CONSTITUENT WILL :OT EXPLAIN A PREDETERMINED FRACTION OF THE VARIANCE. TIDE HEIGHTS

ARE READ INTO CORE STORAGE FROM MAGNETIC TAPE OR CARDS. OTHER INPUT INCLUDES CONSTITUENT SPEEDS IN DEGREES PER SOLAR HOUR, NODE FACTORS, AND EQUILIBRIUM ARGUMENTS IN DEGREES. THE OUTPUT IS AN ORDERED LISTING OF HARMONIC CONSTANTS. NO PROVISION IS MADE FOR ELIMINATION OF COMPONENT EFFECTS. CORE STORAGE NECESSARY - 38,000 WORDS. AUTHOR ROBERT A. CUMMINGS. EARLIER VERSIONS WRITTEN FOR THE IBM 1620-I AND FOR THE IBM 7030 (STRETCH) COMPUTERS.

OCEANOGRAPHY DIVISION

ESSA, COAST AND GEODETIC SURVEY

ROCKVILLE, MD. 20852

( COPY ON FILE AT NODC)

COMPUTES HOURLY VELOCITIES OF THE CURRENT, TIMES OF SLACK AND TIMES

AND VELOCITIES OF MAXIMUM CURRENT USING THE HARMONIC METHOD IN WHICH THE CONSTITUENT VELOCITIES ARE COMBINED INTO THE RESULTANT VELOCITY. HOURLY VALUES ARE SCREENED TO DETERMINE BETWEEN WHICH HOURS A SI_ACK OR MAXIMUM OCCURS. THEN CALCULATION AND COMPARISON OF THE VELOCITIES ARE MADE AT 0.1 HOUR INTERVALS UNTIL THE TIME OF SLACK OR EXTREME VELOCITY IS DETERMINED. CORE STORAGE NECESSARY - 11,000 WORDS - AUTHOR ROBERT A. CUMMINGS.

OCEANOGRAPHY DIVISION

ESSA, COAST AND GEODETIC SURVEY

ROCKVILLE, MD. 20852

NIO PROGRAM 48 - TIDAL ANALYSIS AND PREDICTION

LANGUAGE - CHLF $3 / 4$

COMPUTER - MERCURY

GENERAL PURPOSE PROGRAM FOR (1) THE ANALYSIS OF A YEAR'S HOURLY OBSERVED VALUES OF TIDAL HEIGHT INTO 63 TIDAL CONSTITUENTS, (2) THE PREDICTION OF VALUES OF TIDAL HEIGHT FOR A SPECIFIED PERIOD AND SPECIFIED INTERVAL BETWEEN PREDICTIONS, (3) THE CALCULATION OF RESIDUALS IOBSERVATIONS - PREDICTIONS) FOR A SPECIFIED PERIOD AND INTERVAL. AUTHOR - JAMES CREASE. REF. N.I.O. INTERNAL REPORT NO. N5, PAGES $21-26$. THIS PROGRAM SHOULD BE ADAPTABLE TO THE ATLAS COMPUTER.

NATIONAL INSTITUTE OF OCEANOGRAPHY

WORMLEY, GODALMING, SURREY

ENGLAND

THEORETICAL RADIAL TIDAL FORCE

LANGUAGE - MAD

COMPUTER - IBM 7090

(COPY ON FILE AT NODC)

THERE ARE THREE INPUT FORMATS TO THIS PROGRAM-- I) ASTRONOMICAL DATA

FROM THE NAUTICAL ALMANAC. 2) THE SOLAR EPHEMERIS OBTAINED FROM THE SAME SOURCE. ONLY THE EARTH SUN RADIUS VECTOR IS NEEDED. 3 ) LIST OF LOCAL CONSTANTS, LATITUDE AND LONGITUDE IN DEGREES OF ARC AND MINUTES, ELEVATION IN CENTIMETERS. OUTPUT GIVES LUNAR, SOLAR, AND TOTAL TIDAL FORCES AND THE VECTOR DATE. PROGRAM ACCOMODATES MAXIMUM OF 725 HOURS (30 DAYS) OF DATA IN CORE STORAGE. AUTHOR-- HENRY L. POLLAK.

DEPT. OF EARTH AND PLANETARY SCIENCES

414 SPACE RESEARCH COORDINATION CENTER

UNIVERSITY OF PITTSBURGH

PITTSBURGH, PENNA 15213 
(COPY ON FILE AT NODC)

COMPUTES HOURLY VALUES ALSO TIME AND HEIGHTS OF HIGH AND LOW WATER USING THE HARMONIC METHOD IN WHICH THE CONSTITUENT TIDES ARE COMBINED INTO THE RESULTANT TIDE. HOURLY VALUES ARE SCREENED TO DETERMINE BETWEEN WHICH HOURS A TIDE EXTREME WILL OCCUR, THEN CALCULATION AND COMPARISON OF THE TIDES ARE MADE AT 0.1 HOUR INTERVALS UNTIL THE EXTREME TIDE IS DETERMINED. ANY ARBITRARY DATUM PLANE MAY BE SELECTED. THE OUTPUT IS OPTIONAL AND MAY BE HOURLY TIDES, HIGH AND LOW TIDES, OR BOTH. RUNNING TIME FOR BOTH-- ABOUT 25 SECONDS FOR ONE STATION FOR ONE YEAR • AUTHORS-- N.A. PORE (WEATHER BUREAU) AND R.A. CUMMINGS

(COAST AND GEODETIC SURVEY). EARLIER VERSIONS WRITTEN FOR THE IBM 704 AND IN SOS FOR THE IBM 7090/94. REVISED IN 1966. PROGRAM DESCRIPTION AND LISTING ARE GIVEN IN WEATHER BUREAU TECHNICAL MEMORANDUM WTBM TDL6. JANUARY 1967 .

OCEANOGRAPHY DIVISION

ESSA, COAST AND GEODETIC SURVEY

ROCKVILLE, MD. 20852

TIDES

LANGUAGE - FORTRAN 60

COMPUTER - (NOT GIVEN)

(COPY ON FILE AT NODC)

PREDICTS TIDES IN THE OPEN SEA UTILIZING THE BASIC HYDRODYNAMIC EQUATIONS, FOR THE PRINCIPAL LUNAR SEMIDIURNAL CONSTITUENT M2. APPLICATION IS MADE TO THE ANALYSIS OF THE TIDAL REGIME IN THE GULF OF MEXICO. REF. THESIS BY THOMAS H. GAINER, JR. (MAY 1966, 92 P).

NAVAL POSTGRADUATE SCHOOL

MONTEREY, CALIFORNIA 93940

TIDAL PREDICTION

LANGUAGE - MAC

( COPY ON FILE AT NODC)

COMPUTER - ICT 1301

COMPUTES TIMES OF HIGH AND LOW WATER FOR A PORT FOR ONE YEAR. INPUT, ON PUNCHED CARDS, ARE SPEED, AMPLITUDES, AND INITIAL ANGLES. USES ITERATION METHOD, FOLLOWING NEWTON. SOURCE LANGUAGE-- MANCHESTER AUTOCODE. REQUIRES 800 WORDS STORAGE ON ICT 1301.

UNIVERSITY OF CAPE TOWN

OCEANOGRAPHY DEPARTMENT

ATTN. MR. A.M. SHIPLEY

PRIVATE BAG, RONDEBOSCH, C.P.

REPUBLIC OF SOUTH AFRICA

PREDICTION OF HOURLY TIDE

LANGUAGE - (NOT GIVEN)

COMPUTER - MERCURY

COMPUTES HEIGHT OF TIDE BY EVALUATING A HARMONIC FUNCTION USING 42 COMPONENTS, FOR EACH HOUR OVER A PERIOD OF 370 DAYS. INCLUDES SUBROUTINE FOR COSINE FUNCTION. RUNNING TIME ABOUT 50 MINUTES FOR ONE STATION FOR 370-DAY PERIOD.

HYDROGRAPHER OF THE NAVY

ARGENTINE NAVY HYDROGRAPHIC OFFICE

AVENIDA MONTES DE OCA 2124

BUENOS AIRES, REPUBLICA ARGENTINA

**** WAVES AND HYDROMECHANICS ***-* 
(COPY ON FILE AT NODC)

CALCULATES AND PLOTS WAVE-RAY PATTERNS FOR A COASTAL AREA OF INTEREST. GIVEN A GRID OF DEPTH VALUES, THE INITIAL POSITION OF A WAVE RAY, AND THE DIRECTION OF TRAVEL AND PERIOD OF THE WAVE, SUCCESSIVE POINTS ON THE RAY PATH ARE CALCULATED FOR OUTPUT ON TAPE. THE PLOTTER USES THIS TAPE TO PLOT THE WAVE RAYS. FOR EACH POINT ON THE PATH, WATER DEPTH AND BOTTOM SLOPE ARE INTERPOLATED FROM THE DEPTH GRID, WAVE SPEED AND CURVATURE ARE COMPUTED ACCORDING TO CLASSIC THEORY, AND THE COORDINATES OF THE NEXT POINT ARE APPROXIMATED BY AN ITERATION PROCEDURE. APPROXIMATELY 11,000 POSITIONS OF STORAGE ARE REQUIRED FOR THE DATA IEXCLUSIVE OF DEPTH GRID) AND THE PROGRAM. IN ADDITION, ONE MEMORY POSITION IS NECESSARY FOR EACH COORDINATE INTERSECTION ON THE DEPTH GRID. REPORTED IN TECHNICAL MEMORANDUM NO. 17 (1966) OF THE U.S. ARMY COASTAL ENGINEERING RESEARCH CENTER (CERC), WASHINGTON, D.C. 20016 . AUTHOR-- W. STANLEY WILSON, JOHNS HOPKINS UNIV. CARD DECK AND TMI7 DEPOSITEC AT CERC.

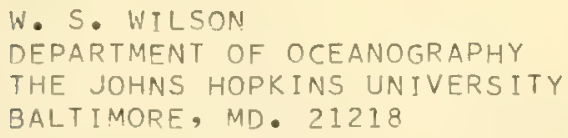

WAVES

LANGUAGE - SCRAP

COMPUTER - CDC 1604

COMPUTES WIND WAVE AND SWELL - HEIGHT, PERIOD, DIRECTION, MEAN WAVE HEIGHT FOR PAST 36 HOURS. INPUT ARE SURFACE WINDS, SEA SURFACE TEMPERATURE, AND ANALYZED WAVE HEIGHTS FOR PAST 72 HOURS. OUTPUT ANAI_YSIS INCLUDES I2, 24, 36, 48 HOUR WIND WAVE AND SWELL HEIGHTS AND COMBINED HEIGHTS, ETC. CORE STORAGE NEEDED-- $76046(8)$ WORDS. ADDITIONAL_ STORAGE-- 24 UNIVAC DRUM BLOCK AREAS OF $7634(8)$. DIRECT INQUIRIES TO--

COMMANDING OFFI CER

FLEET NUMERICAL WEATHER CENTRAL

MONTEREY, CALIFORNIA 93940

\section{GENERATION OF WATER WAVES BY TURBULENT WIND FLOW LANGUAGE - FORTRAN \\ (COPY ON FILE AT NODC) \\ COMPUTER - IBM $360 / 67$ \\ PROGRAM COMPUTES VELOCITY PROFILE, NORMAL PRESSURE, TANGENTIAL SHEAR STRESS, AND WAVE GROWTH RATE. REF. THESIS BY PAUL R. KLINEUINST, JR., JUNE 1968 (UNPUBLISHED MS.).}

NAVAL POSTGRADUATE SCHOOL

MONTEREY, CALIFORNIA 93940

OPTIMUM TRACK SHIP ROUTING

$\begin{aligned} \text { LANGUAGE - } & \text { MACHINE AND } \\ & \text { FORTRAN IV } \\ \text { COMPUTER - } & \text { PB-440 AND } \\ & \text { UNIVAC } 1107\end{aligned}$

SELECTS OPTIMUM ROUTES FOR OCEAN VESSELS TRANSITING N. ATLANTIC OCEAN, GIVEN INPUT DATA ON SEA HEIGHTS AND DIRECTION. OUTPUT-- MAG TAPE AND PRINTOUT INDICATING OPTIMUM PATH OF SHIP, AND TIME REQUIRED TO CROSS BY BOTH OPTIMUM AND PRESPECIFIED FIXED ROUTE. AUTHOR-- F.W. NAGLE.

COMMANDING OFFICER

NAVY WEATHER RESEARCH FACILITY

BLDG. R-48, NAVAL AIR STATION

NORFOLK, VIRGINIA 23511 
CALCULATES THE OPTIMUM TRACK SHIP ROUTE OF A VCZAP3 VESSEL ON A TRANSPACIFIC VOYAGE. THE PROGRAM CAN BE MOUIFIED EASILY TO PROVIDE ROUTES FOR OTHER TYPE VESSELS IN ANY OCEAN AREA OF THE N. HEMISPHERE. USES TWO ADVANCES IN THE CALCULUS OF VARIATIONS METHOD FOR MINIMAL-TIME SHIP ROUTING. INCORPORATES LONG-RANGE (5-DAY AND 30-DAY) WEATHER FORECASTS TO EXTRAPOLATE THE FNWC OCEAN WAVE FIELD FORECASTS TO EIGHT DAYS. MAIN PROGRAM AND SUBROUTINES LISTED IN TECHNICAL REPORT NO. 81 ( JULY 1967), BY G.J. HALTINER, W.E. BLEICK, AND F.D. FAULKNER•

NAVAL POSTGRADUATE SCHOOL

MONTEREY, CALIFORNIA 93940

(COPY ON FILE AT NODC)

COMPUTES THE SEICHE PARAMETERS IN ACTUAL BASINS, GULFS OR BAYS. REF. SPECIAL REPORT NO. 4 'DIGITAL COMPUTER PROGRAMS FOR THE DEFANT METHOD OF SEICHE ANALYSIS', JULY 1968, BY EVERETT J. FEE.

THE LIBRARIAN

CENTER FOR GREAT LAKES STUDIES

UNIVERSITY OF WISCONSIN-MILWAUKEE

MILWAUKEE, WISCONSIN 53201 USA

PROFIL (TSUNAMI PROFILES)

LANGUAGE - FORTRAN IV

COMPUTER - IBM 7094

TREATS A TSUNAMI OR OTHER LONG WAVE AS IF IT WERE A TRAIN OF UNIFORM PERIODIC WAVES MOVING OVER A BOTTOM OF CONSTANT SLOPE, USING LINEAR SHALLOW-WATER THEORY. THE RESULTS ARE PLOTTED ON A SERIES OF GRAPHS. PROGRAM LISTED IN TECHNICAL REPORT HEL 16-1 (OCT 1966) 'LONG WAVE PROFILES OVER A SLOPE', BY R.H. CROSS AND R.L. WIEGEL.

UNIVERSITY OF CALIFORNIA

HYDRAULIC ENGINEERING LABORATORY

BERKELEY, CALIFORNIA 94720

WAVE SHOALING

( COPY ON FILE AT NODC)

CALCULATES THE TRANSFORMATION OF A WAVE PROPAGATING FROM DEEP WATER TO THE SHORE, APPLYING THE PRINCIPLE OF CONSERVATION OF ENERGY FLUX. THE FIFTH ORDER GRAVITY WAVE THEORY OF SKJELBREIA AND HENDRIKSON (I960) IS USED IN THE CALCULATIONS. THE QUALITATIVE FEATURES OF THE RESUI-TS ARE THE SAME AS THOSE OBTAINED BY LE MEHAUTE AND WEBB (1964). HOWEVER, THE SHOALING COEFFICIENT IS SMALLER IN MAGNITUDE. REF. NESCO REPORT SN-134-9 (1966), BY R.C.Y. KOH AND B.J. LE MEHAUTE. PROGRAMERS-- ROBERT WHALIN AND MARYANN MOORE.

NATIONAL ENGINEERING SCIENCE CO.

711 SOUTH FAIR OAKS AVE.

PASADENA, CALIFORNIA

\section{SUBROUT INE LENG I}

(COPY ON FILE AT NODC) COMPUTES WAVE LENGTHS AND SPEED OF GRAVITY WAVES, GIVEN THE PERIOD AND WATER OEPTH, USING SMALL-AMPLITUDE (AND STOKES, SECOND-ORDER) WAVE THEORY. OUTPUT ARE WAVE LENGTH AND SPEED, AND THE DEEP-WATER WAVE LENGTH. THE IMPLICIT EQUATIONS ARE APPROXIMATED, THEN ITERATION IS PERFORMED TO REDUCE THE ERROR.

PROF. RALPH H. CROSS

ROOM 48-209 HYDRODYNAMICS LABORATORY

MASSACHUSETTS INSTITUTE OF TECHNOLOGY
LANGUAGE - FORTRAN IV

COMPUTER - IBM $360 / 40$ 
( COPY ON FILE AT NODC)

COMPUTES AND PLOTS THE WAVE PROFILE GIVEN THE SPECTRUM (IN THE FORM OF THE FOURIER COEFFICIENTS). INPUT-- THE NUMBER OF COMPONENTS, AND THE NUMBER OF VALUES OF ETA TO BE COMPUTED AND PLOTTED, ARE READ IN AT EXECUTION TIME. OUTPUT-- A PRINTER PLOT ION A PRINTER WITH A 132-CHARACTER LINE) OF ETA VS. T. REF. TECH. NOTE NO. 13 'WATER WAVE TEACHING AIDSI (R.H. CROSS, SEP 1968), HYDRODYNAMICS LABORATORY, DEPARTMENT OF CIVIL ENGINEERING.

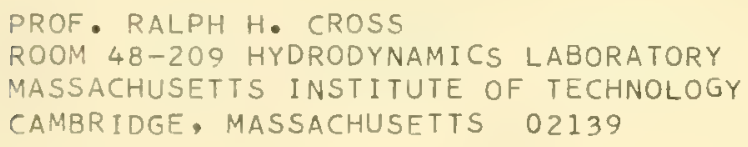

(COPY ON FILE AT NODC)

COMPUTES WATER SURFACE ELEVATIONS, ETA(X) OR ETA(T), OVER A WAVE PERIOD, USING LINEAR WAVE THEORY. INPUT-- WAVE HEIGHT, PERIOD AND LENGTH, AND THE WATER DEPTH. OUTPUT-- RETURNS THE THREE ARRAYS OF $X, T$, AND ETA FOR T=0, PER/40,....PER AND $X=0, L / 40,2 L / 40, \ldots, L$. WRITEUPS AND LISTING IN TECHNICAL NOTE NO. 13 OF THE HYDRODYNAMICS LABORATORY. ALTERNATIVE SUBROUTINES, PROF2 AND PROF3, ACCOMPLISH THE SAME PURPOSE USING STOKES' SECOND- AND THIRD-ORDER WAVE EQUATIONS.

PROF. RALPH H. CROSS

ROOM 48-209 HYDRODYNAMICS LABORATORY

MASSACHUSETTS INSTITUTE OF TECHNOLOGY

CAMBRIDGE, MASSACHUSETTS 02139

(COPY ON FILE AT NODC)

COMPUTES WATER SURFACE PROFILES FOR THE PARTIAL (TWO-DIMENSIONAL) REFLECTION OF A LINEAR (SMALL-AMPLITUDE) WAVE FROM A STRUCTURE. INPUT THE INCIDENT WAVE HEIGHT, PERIOD, AND LENGTH, THE WATER DEPTH, AND THE REFLECTION COEFFICIENT - OUTPUT-- PRINTS WATER SURFACE PROFILES FOR TWO WAVE LENGTHS, FOR $T=0, T / 4, T / 2$, AND 3T/4. DOCUMENTATION IS IN TECHNICAL NOTE 13, M.I.T. HYORODYNAMICS LABORATORY (SEPT $1968,92 \mathrm{P})$.

PROF. RALPH H. CROSS

ROOM 48-209 HYDRODYNAMICS LABORATORY

MASSACHUSETTS INSTITUTE OF TECHNOLOGY

CAMBRIDGE, MASSACHUSETTS 02139

SUBROUTINES UOFTI, WOFTI, UTOFTI, WTOFTI PECT TO T, OR THE PARTIAL DERIVATIVE OF W WITH RESPECT TO T, I.E. THE HORIZONTAL AND VERTICAL FLOW VELOCITIES AND THEIR ACCELERATIONS OVER A NAVE PERIOD AT A GIVEN DEPTH, Z, USING LINEAR WAVE THEORY. INPUT ARE WAVE HEIGHT, PERIOD, AND LENGTH, THE WATER DEPTH, AND THE DESIRED VALUE OF $Z$. OUTPUT-- RETURNS ARRAYS OF T AND U(T), W(T), ETC., FOR $T=O$, PER/40, 2PER/40,...PER. ALTERNATE SETS OF SUBROUTINES CARRY OUT THE SAME PURPOSE USING STOKES' SECOND- AND THIRD-ORDER WAVE EQUATIONS. "RITEUPS AND LISTINGS IN TECHNICAL NOTE NO. 13 OF THE M.I.T. HYDRODYNAMICS LABORATORY (SEPT 1968 ). 
( COPY ON FILE AT NODC)

COMPUTES U(MAX), W(MAX), THE PARTIAL DERIVATIVE OF U WITH RESPECT TO T $(M A X)$, OR THE PARTIAL DERIVATIVE OF W WITH RESPECT TO T (MAX) I.E. THE MAXIMUM FLOW VELOCITIES IN THE $X$ AND $Z$ DIRECTIONS AND THEIR CORRESPONDING TEMPORAL ACCELERATIONS, AS A FUNCTION OF $Z$, FROM $Z=-H$ TO $Z=$ ETA(MAX), USING LINEAR WAVE THEORY. INPUT-- WAVE HEIGHT, PERIOD, AND LENGTH, AND THE WATER DEPTH. OUTPUT-- RETURNS ARRAYS OF $Z$ AND UMAX $(Z)$ ETC., FOR $Z=-H,-(29 / 30) \mathrm{H},-(28 / 30) \mathrm{H}, \ldots$ FOR $Z$ LESS THAN ETA $(M A X)$. ALTERNATE SETS OF ROUTINES CARRY OUT THE SAME PURPOSE USING STOKES: SECOND- AND THIRD-ORDER EQUATIONS. WRITEUPS AND LISTINGS IN TECHNICAL NOTE NO. 13 OF THE M.I.T. HYDRODYNAMICS LABORATORY.

PROF. RALPH H. CROSS

ROOM 48-209 HYDRODYNAMICS LABORATORY

MASSACHUSETTS INSTITUTE OF TECHNOLOGY

CAMBRIDGE, MASSACHUSETTS 02139

WAVE FORCE DISTRIBUTION, TEMPORAL AND SPACIAL LANGUAGE - FORTRAN IV

(COPY ON FILE AT NODC)

COMPUTER - IBM $7090 / 94$

GIVEN THE WATER DENSITY, THE WATER DEPTH, THE PILE DATA, AND A CHOICE OF WAVE HEIGHT AND PERIOD COMBINATIONS, THIS PROGRAM COMPUTES THE DISTRIBUTION OF FORCE ALONG A PILE OF ANY SHAPE. ALSO CALCULATED IS THE FORCE AT THE WATER SURFACE. THESE DISTRIBUTIONS ARE CALCULATED FOR TWENTY EQUALLY SPACED POINTS THROUGHOUT THE WAVE CYCLE. IF THE VALUES OF $C(M)$ AND $C(D)$, (MASS AND DRAG COEFFICIENTS), ARE UNSPECIFIED, THE VALUES ASSUMED ARE $C(M)=2.0$ AND $C(D)=1.6$. THE PROGRAM ALLOWS OTHER VALUES TO BE SPECIFIED IN CASE THE SITUATION (I.E., THE PILE SHAPE) CALLS FOR IT. PROGRAM WRITTEN FOR THE WAVE RESEARCH LAB AT THE UNIV. OF CALIF. REF. HEL REPORT 9-4 'WAVE FORCE PROGRAMS', BY R•H. CROSS.

PROF. RALPH H. CROSS

ROOM 48-209 HYDRODYNAMICS LABORATORY

MASSACHUSETTS INSTITUTE OF TECHNOLOGY

CAMBRIDGE, MASSACHUSETTS 02139

WAVE FORCES AND MOMENTS

LANGUAGE - FORTRAN IV

COMPUTER - IBM 7090/94

( COPY ON FILE AT NODC,

GIVEN THE DESIRED COMBINATIONS OF WAVE HEIGHT AND PERIOD, PILE DIAMETER, AND WATER DEPTH, COMPUTES THE WAVE LENGTH, CHECKS FOR EXCESSIVE STEEPNESS, AND COMPUTES THE TOTAL FORCE ON, AND THE MOMENT ABOUT THE BASE OF, THE PILES CHOSEN. THE FORMULAS USED ARE DERIVED FROM LINEAR THEORY EXCEPT THAT INTEGRATION IS CARRIED TO THE FREE SURFACE, AS CALCULATED. FORCE AND MOMENT ARE COMPUTED FOR 40 POINTS IN A WAVE CYCLE. REF. U. OF CALIF. HEL REPORT 9-4 'WAVE FORCE PROGRAMS' BY R•H. CROSS.

PROF. RALPH H. CROSS

ROOM 48-209 HYDRODYNAMICS LABORATORY

MASSACHUSETTS INSTITUTE OF TECHNOLOGY

\section{SEAKEEP ING}

LANGUAGE - FORTRAN IV

( COPY ON FILE AT NODC)

COMPUTER - IBM 1130

PREDICTS HEAVE, PITCH, AND ACCELERATION OF A DESIGNATED HULL FORM IN REGULAR WAVES OVER A RANGE OF WAVE LENGTHS AND WAVE AMPLITUDES. THE PROGRAM IS DIVIDED INTO FOUR MAINLINE SECTIONS-- PART I SETS UP THE INPUT DATA FOR THE TWO CALCULATING SECTIONS OF THE PROGRAM. PART II CALCULATES THE SIMULATED ADDED MASS AND AMPLITUDE OF THE GENERATED WAVES OF THE HULL FORM. PART III CALCULATES THE AMPLITUDES OF HEAVE, PITCH, AND ACCELERATION, AND PART IV PLOTS AND CURVE FITS THIS INFORMATION. REPORT REF. NO. USCG-PROGRAM-ENE-I2 (JUL 68, 116 P) BY JACK 
W. LEWIS, ICEBREAKER DESIGN BRANCH.

U. S. COAST GUARD HEADQUARTERS

NAVAL ENGINEERING DIVISION

1300 E ST. NW

WASHINGTON, D. C. 20591

LONGITUDINAL STRENGTH OF SHIP HULL

\author{
LANGUAGE - FORTRAN IV \\ COMPUTER - IBM 7090
}

EXTENDS THE STATIC BALANCE METHOD OF CALCULATING SHEAR AND BENDING MOMENT RESPONSES TO INCLUDE A WIDE RANGE OF WAVE HEIGHTS, LENGTHS, AND POSITIONS WITH RESPECT TO AMIDSHIPS FOR A SHIP VERTICALLY BALANCED IN HEAD-ON TROCHOIDAL WAVES. THE PROGRAM HAS THE OPTION OF INCIUDING OR OMITTING THE SMITH CORRECTION, AND THE FINAL DATA MAY BE PRESENTED IN EITHER TABULAR OR GRAPHICAL FORM. PROGRAM YPO4 PROVIDES A MEASURE OF THE LONGITUDINAL STRENGTH FROM THE STATIC BALANCE. YPO5 IS A METHOD OF PLOTTING THE LONGITUDINAL STRENGTH CURVES, PROGRAMMED BY MRS. SHARON E. GOOD. REF. REPORT NO. 2272 (JAN 67, 93 P), BY GEOFFREY O. THOMAS. ODC NO. IS AD-647-807.

MR. GENE H. GLEISSNER

HEAD, APPLIED MATHEMATICS LABORATORY

NAVAL SHIP RESEARCH AND DEVELOPMENT CENTER

WASHINGTON, D.C. 20007

WAVE STATISTICS (PART I AND PART II) LANGUAGE - FORTRAN IV
COMPUTER - IBM OS/360

DETERMINES WAVE STATISTICS OF A SEA RECORD. THE STATISTICS INCILUDE-NUMBER OF WAVES, R.M.S., MEAN, MAX., AND SIGNIFICANT WAVE HEIGHT, AND SPECTRAL DECOMPOSITION OF THE SEA SURFACE. OUTPUT-- PRINTOUT OF WAVE STATISTICS, AND PLOT OF SPECTRAL ESTIMATE. AUTHOR-- J. E. MAMRING.

PROF. FREDERICK F. MONROE

DEPT. OF OCEAN ENGINEERING

FLORIDA ATLANTIC UNIVERSITY

BOCA RATON, FLORIDA 33432

WAVEIN AND DIFRAK

LANGUAGE - FORTRAN

COMPUTER - IBM 7094 AND CDC 6400

A PAIR OF PROGRAMS FOR (1) SPECTRAL ANALYSIS OF WAVE DATA, AND (2)COMPUTATION AND PLOT OF THE DIFFRACTION COEFFICIENTS. AUTHOR-- SHOU-SHAN FAN, C.E.R.C. WASH., D.C.

PROF. ROBERT L. WIEGEL

DEPARTMENT OF CIVIL ENGINEERING

UNIVERSITY OF CALIFORNIA

BERKELEY, CALIF. 94720

REFRACTION OF WAVES APPROACHING A COASTLINE

LANGUAGE - FORTRAN IV

COMPUTER - IBM $7090 / 94$

A PROGRAM TO CONSTRUCT REFRACTION DIAGRAMS AND COMPUTE WAVE HEIGHTS FOR WAVES MOVING INTO SHOALING WATER. CONSISTS OF MAIN PROGRAM WAVES I AND SUBROUTINES RAYCON, REFRAC, CURVE, DEPTH, HEIGHT, ERROR, WRITER. SOLVES THE REFRACTION EQUATION AND THE WAVE INTENSITY EQUATION FOR ARBITRARY BOTTOM SHAPES. SOLUTION WAS SOUGHT BY USE OF THE NUMERICAL METHODS OF FINITE DIFFERENCES. ONE OF THREE HYDRAULIC ENGINEERING PROBLEMS DESCRIBED IN TECH. REPT. NO. TR-80 (JUN 67, 185 P) BY R. S. DOBSON. PROGRAMS ARE LISTED IN THE REPORT. THE DDC NUMBER IS AD-659309.

DEPT. OF CIVIL ENGINEERING 
LANGUAGE - FORTRAN IV

COMPUTER - IBM $7090 / 94$

INVESTIGATES AND COMPARES THE LABORATORY SIMULATED AND PROTOTYPE 'SEA' DATA. USES PROGRAMS WAVHTS ICOMPUTE WAVE HEIGHTS AND THEIR STATISTICAL PROPERTIES), SPECTR (COMPUTE NORMALIZED SPECTRUM), STATS (COMPUTE VARIOUS STATISTICAL PROPERTIES OF THE SEA SURFACE RECORD), AND CONVRT (CONVERTS SCRAMBLED VOLTAGE RECORDS TO TIME SERIES OF SURFACE DISPLACEMENT). REF. TECH. REPORT NO. 65 'LABORATORY SIMULATION OF SEA WAVES, (JUL 1966,134 P), BY JOSEPH M. COLONELL.

STANFORD UNIVERSITY

DEPT. OF CIVIL ENGINEERING

STANFORD, CALIIFORNIA 
A SET OF FOUR PROGRAMS WHICH CONSTITUTE A COMPLETE SYSTEM FOR PREPARING, MAINTAINING AND ACCESSING A MAGNETIC TAPE FILE OF BIOLOGICAL STATION DATA. N.I.O. PROGRAMS $94,94 / \mathrm{A}, 94 / \mathrm{B}$, AND $94 / \mathrm{C}$. AUTHORS-- MARGARET RINGROSE AND BRIAN HINDE.

NATIONAL INSTITUTE OF OCEANOGRAPHY

WORMLEY, GODALMING, SURREY

ENGLAND

THERE ARE THREE DIFFERENT OPTIONS AVAILABLE-- (I) GIVEN TWO POINTS ON THE EARTH'S SURFACE, THE PROGRAM CALCULATES THE GREAT CIRCLE ROUTE BETWEEN THE TWO POINTS AND THE CORRESPONDING MARSDEN SQUARES ALONG AND AT A GIVEN DISTANCE FROM THE TRACK. THE DATA TAPES ARE SEARCHED BY MARSDEN SQUARES AND THE SOUND VELOCITY PROFILES, TEMPERATURE, SALINITY AND DEPTH OF OBSERVATION ARE ABSTRACTED. $(2)$ INDIVIDUAL MARSDEN SQS. MAY BE INPUT INTO THE PROGRAM AND THE ABOVE QUANTITIES ARE ABSTRACTED. (3) A POINT, A RADIUS OF INTEREST IN NAUTICAL MILES, AND A CLUSTER OF MARSDEN SQUARES MAY BE SPECIFIED. THE PROGRAM WILL ABSTRACT ALL THE STATIONS WITHIN A CIRCULAR AREA OF THE POINT FOR THE GIVEN MONTHS. THE INPUT RETRIEVAL PROGRAF, BY WALTER YERGEN, USES DATA TAPES COMPACTED FROM THE NODC FILE. STORAGE REQUIREMENTS-- 105,056 OCTAL WORDS OF CORE, AND ONE CDC DISC FILE.

B. G. ROBERTS, JR., CODE 8177

ACOUSTICS DIVISION

NAVAL RESEARCH LABORATORY, WASHINGTON, D. C. 20390

(COPY ON FILE AT NODC)

A PROGRAM PACKAGE DESIGNED FOR USE ON A RECONNAISSANCE BASIS. LISTING ALL CORES IN THE L-DGO COLLECTION CONTAINING CHARACTERISTICS SPECIFIED BY THE USER. THE PROGRAM OUTPUTS THE REQUIRED LIST OF CORES WITH A SHORT DESCRIPTION OF EACH CORE. AS SPECIFIED ON FOUR CONTROL CARDS, CORES MAY BE REQUESTED FROM CERTAIN LOCATIONS, OF CERTAIN LENGTHS, TAKEN IN A CERTAIN RANGE OF WATER DEPTHS, OF SPECIFIED AGE, LITHOLOGY AND CONTAINING SPECIFIC PALEONTOLOGIC AND MINERALOGIC COMPONENTS. CORES WHICH ARE ORIENTED. HAVE APPEARED IN PUBLICATIONS AND HAVE PALEOMAGNETIC DATA AVAILABLE CAN ALSO BE REQUESTED.

MR. ROY R. CAPO

CORE CURATOR

LAMONT-DOHERTY GEOLOGICAL OBSERVATORY

PALISADES, NEW YORK 10964

( COPY ON FILE AT NODC)

A SYSTEM OF PROGRAMS AND SUBROUTINES FOR THE STORAGE, EDITING, AND RETRIEVAL OF DATA, SET UP BY THE MARINE GEOPHYSICS GROUP AT BEDFORD INSTITUTE OF OCEANOGRAPHY. THE MAIN RETRIEVAL PROGRAM SEARCHES FOR A PARTICULAR FILE ON TAPE, READS AND PRINTS FILE LABELS, AND CONTROLS THE PROCESSING SUBROUTINES CALLED. DOCUMENTED IN BIO COMPUTER NOTE 67-3-C (NOV 1967), BY D. I. ROSS. 
PROGRAM I - FACILITATES UPDATING OF CHARTS THAT DEPICT THE GEOGRAPHICAL DATA DISTRIBUTION ILLUSTRATED IN THE OCEANOGRAPHIC DATA CATALOGUE. PROGRAM II - COMPILES AND LISTS AN INDEX OF CANADIAN REFERENCE NUMBERS IN GEOGRAPHICAL SEQUENCES FOR THE OCEANOGRAPHIC DATA CATALOGUE. AUTHOR- - J. ZEBARTH.

CANADIAN OCEANOGRAPHIC DATA CENTRE 615 BOOTH STREET

OTTAWA, CANADA 
ADELPHI UNIVERSITY

CHLOROPHYLL AND CAROTENOID PIGMENT IBM $1620 I$ IFORTRAN I

05

ARGENTINE NAVY HYDROGRAPHIC OFFICE

PREDICTION OF HOURLY TIDE MERCURY NOT GIVEN 105

ARMY CORPS OF ENGINEERS, LAKE SURVEY DISTRICT

SEDIMENT TEXTURAL ANALYSIS

NOT GIVEN FORTRAN

ARTHUR D. LITTLE, INC.

ACOUSTIC RAY TRACING

IBM 7090 FORTRAN II 94

TWO-DIMENSIONAL AUTOCORRELATION

IBM 7090, FORTRAN 56

TRLOSS (TRANSMISSION LOSS)

IBM 1401

CDC 6600 FORTRAN 94

BEDFORD INSTITUTE OF OCEANOGRAPHY

DATA REDUCTION FOR THE CDC 3100

DATA REDUCTION FOR THE PDP-8

ISALBP (SALINITY ANOMALY)

ISATBP IOXYGEN ANOMALY AND SAT.

LEAST SQUARES CURVE FITTING

PLOT STATION POSITIONS

PLOT THETA-S CURVES

SECTION PLOTTING

TIME SERIES PLOTTING

STADAT 2

RETRIEVAL OF GEOPHYSICAL DATA

CDC 3100 FORTRAN I I I4,83

$\begin{array}{lll}\text { PDP-8 } & \text { PAL III } & 14\end{array}$

CDC 3100 FORTRAN II 10

CDC 3100 FORTRAN I I 10

CDC 3100 FORTRAN II 45

CDC 3100 FORTRAN II 36

CDC 3100 FORTRAN II 35

CDC 3100 FORTRAN 36

CDC 3100 FORTRAN-32 36

GE 200 SERFORTRAN II 14

NOT GIVEN FORTRAN 112

BERGEN, UNIVERSITY OF

PROCESSING OF OCEANOGRAPHIC OBS • IBM 1620 IIFORTRAN I

BUREAU OF COMMERCIAL FISHERIES, HAWAI I

AOU, ISAOU (CALC. OF OXYGEN, ETC. GDNP, GRAD (CALC. OF GRADIENTS)

GVPA, VPA (CALC. OF CURRENTS)

ISOS, OXOS, PHOS (ISENTROPIC PLOT)

LENGTH-WEIGHT FREQUENCY

LONG WAVE RADIATION

OCEANOGRAPHIC REPORT PREPARATION

OCEANOGRAPHIC SUMMARY (NOS, 1,2,3)

REVERSING THERMOMETER CORRECTION

TSIP, THOX, THOT (PLOT TIME HISTORY)

$\begin{array}{llll}\text { IBM } & 360 / 65 F O R T R A N & \text { IV } & 10 \\ \text { IBM } & 360 / 65 \text { FORTRAN } & \text { IV } & 76 \\ \text { IBM } & 360 / 65 \text { FORTRAN } & \text { IV } & 69 \\ \text { IBM } & 360 / 65 \text { FORTRAN } & \text { IV } & 40 \\ \text { IBM } & 360 / 65 F \text { ORTRAN } & \text { IV } & 06 \\ \text { IBM } & 360 / 65 \text { FORTRAN } & \text { IV } & 25 \\ \text { IBM } & 360 / 65 F \text { ORTRAN } & \text { IV } & 91 \\ \text { IBM } & 360 / 65 F \text { ORTRAN } & \text { IV } & 79 \\ \text { IBM } & 360 / 65 \text { FORTRAN } & \text { IV } & 20 \\ \text { IBM } & 360 / 65 \text { ORTRAN } & \text { IV } & 41\end{array}$

BUREAU OF COMMERCIAL FISHERIES, LA JOLLA

SEA SURFACE TEMP. AND ANOMALY SUM. SEA SURFACE TEMP. DATA SUMMARY

$\operatorname{CDC} 3600$

CDC 3600

SYNOPTIC MARINE WEATHER DATA SUMMARY CDC 3600

VACOTS (VERTICAL SECTION PLOT)

CDC 3600

FORTRAN-62

81

FORTRAN-62 81

FORTRAN-62 80

FORTRAN-63 39 
BUREAU OF COMMERCIAL FISHERIES, MIAMI

FLOW METER PLOTS

GENERAL MERCATOR PLOT

HORIZONTAL SECTIONS

IN SITU OCEANOGRAPHIC DATA

INTERPOLATION

MERCATOR STATION PLOT

OXYGEN, PHOSPHATE, DENSITY PLOTS

TEMPERATURE-SALINITY CURVES

CALIFORNIA, UNIVERSITY OF

WAVEIN AND DIFRAK

PROFIL (TSUNAMI PROFILES)
IBM 360/65FORTRAN IV 72

IBM $360 / 65 F O R T R A N$ IV 40

IBM 360/65FORTRAN IV 40

IBM $360 / 65$ FORTRAN IV 85

IBM 360/65FORTRAN IV 86

IBM $360 / 65 F O R T R A N$ IV 40

IBM $360 / 65 F O R T R A N$ IV 39

IBM 360/65FORTRAN IV 39

CANADIAN OCEANOGRAPHIC DATA CENTRE

DAILY SEAWATER OBSERVATIONS

OCEANS II REPORT GENERATOR

OCEANS III

OCEANS CATALOGUE I AND II

STATISTICS I, II, III

THERMOCHECK II - TEMP . CORRECTION

TEMPERATURE-SALINITY PLOT
CDC 3100, FORTRAN IV, 79

IBM 1620 FORTRAN II-D

IBM 1401 SPS

IBM 360/65FORTRAN IV

CDC 3100 FORTRAN IV 113

CDC 3100 FORTRAN IV 56

CDC 3100, FORTRAN IV 17

IBM $360 / 65$

CDC 3100 FORTRAN

CAPE TOWN, UNIVERSITY OF

\begin{tabular}{|c|c|c|c|c|}
\hline CHLOROPHYLL CALCULATIONS & ICT & 1301 & MAC & 07 \\
\hline DELTA-ALPHA AND SIGMA-T & $I C T$ & 1301 & MAC & 93 \\
\hline HARMONIC ANALYSIS & ICT & 1301 & MAC & 51 \\
\hline TIDAL PREDICTION & ICT & 1301 & MAC & 10 \\
\hline VELOCITY OF SOUND & ICT & 1301 & $M A C$ & 103 \\
\hline
\end{tabular}

COAST AND GEODETIC SURVEY, SEATTLE

CONDU (THERMAL CONDUCTIVITY) IBM7094-IIFORTRAN IV

17040 DCS

COAST AND GEODETIC SURVEY, WASHINGTON, D. C.

ASTRONOMICAL TIDE PREDICTION

COMPUTE GEOGRAPHIC POSITIONS

CDC $6600 \quad$ FORTRAN-66 104

IBM 1620 SPS 61

HARMONIC ANALYSIS OF TIDAL DATA

CDC 6600, FORTRAN IV

103

LORAN C

TIDAL CURRENT PREDICTION

IBM 7030 FORTRAN I I

IBM 1620 SPS

CDC 6600 FORTRAN IV $\quad 62$

VELOCITY OF SOUND

IBM 1620

FORTRAN

COAST GUARD OCEANOGRAPHIC UNIT

OXYGEN COMPUTATION

PHOSPHATE COMPUTATION

SALINITY CONVERSION

$\mathrm{H}-516$

$\mathrm{H}-516$

$\mathrm{H}-516$

THERMOMETER CORRECTION

$\mathrm{H}-516$

$\begin{array}{lll}\text { FORTRAN IV } & 11 \\ \text { FORTRAN } & \text { IV } & 11 \\ \text { FORTRAN } & \text { IV } & 11 \\ \text { FORTRAN IV } & 16\end{array}$

COAST GUARD HEADQUARTERS, OFFICE OF ENGINEERING 
COLUMBIA UNIVERSITY, HUDSON LABORATORIES

COMMERCE, DEPARTMENT OF (SEE COAST AND GEODETIC SURVEY)

DEFENSE, DEPARTMENT OF (SEE FLEET..., NAVAL..., NAVY...)

DEFENSE RESEARCH ESTABLISHMENT PACIFIC

RAYTR (RAY-TRACING)

IBM $360 / 44 F U R T R A N$ IV

DIGITAL EQUIPMENT COMPUTER USERS' SOCIETY

DECCA HI-FIX

DISSOLVED OXYGEN, POTENTIAL TEMP. OCEAN STATION ANALYSIS AND SUMMARY

THERMOMETER CORR. AND THERMO. DEPTH
POP-5, 85 FORTRAN

$P D P-5,85$ PAL III

PDP-5, 8S PAL III

PDP-5, 85 PAL III
64

93

93

20

FLEET NUMERICAL WEATHER CENTRAL

DATA FIELD GRID EXPANSION

FORECASTING OF SURFACE CURRENTS

GG T SEA

POTENTIAL MIXED LAYER DEPTH

SEA SURFACE TEMPERATURE ANALYSIS

SUBSURFACE THERMAL STRUCTURE ANALYSISCI

TWO DIMENSIONAL RAY TRACE

WAVES

CDC 1604, MACHINE

CDC 3100

CDC 1604, MACHINE 67

$\operatorname{CDC} 3200$

CDC 1604 MACHINE

CDC 1604, MACHINE

CDC 3200

CDC 1604 MACHINE

CDC 1604 SCRAP

CDC 1604, SCRAP, MAP

$\operatorname{CDC} 3200$

CDC 1604 SCRAP

FLORIDA ATLANTIC UNIVERSITY

WAVE STATISTICS

IBM OS/36OFORTRAN IV

110

FLORIDA STATE UNIVERSITY

MULTIVARIATE NON-LINEAR REGRESSION

IBM 709 ,

CDC 6400

IBM 709 ,

CDC 6400

IBM 709 ,

CDC 6400

FORTRAN II 47

AND IV

FORTRAN II 90

FORTRAN II 29

68

81

82

99

06
IBM 360/65FORTRAN IV $-H \quad 59$

IBM 360/65PL/I 45

IBM 360/65FORTRAN IV-G 10

IBM 360/65FORTRAN IV-H 26

IBM 360/65FORTRAN IV-H 26

IBM 360/65FORTRAN IV 09

INFORMATION INTERNATIONAL, INC.

RICHARDSON CURRENT METER FILM READ. POP-7(9) DECAL 
INTERIOR, DEPARTMENT OF THE (SEE BUREAU OF COMMERCIAL FISHERIES, GEOLOGICAL SURVEY)

JOHNS HOPKINS UNIVERSITY

$\begin{array}{llllr}\text { CHLORINITY - SALINITY } & \text { IBM } 7094 & \text { FORTRAN II } & 12 \\ \text { CONTINUOUS LINE SOURCE } & \text { IBM } 7094 & \text { FURTRAN II } & 71 \\ \text { CONTINUOUS SOURCE PER UNIT DEPTH } & \text { IBM } 7094 & \text { FURTRAN II } & 71 \\ \text { CONTINUOUS SOURCE, WITH COOLING TERM IBM } 7094 & \text { FORTRAN II } & 71 \\ \text { DENSITY - THERMOSTERIC ANUMALY } & \text { IBM } 7094 & \text { FURTRAN II } & 90 \\ \text { LATERAL RELATIVE DISTRIBUTION } & \text { IBM } 7094 & \text { FORTRAN II } & 70 \\ \text { SALINITY DISTRIBUTION IN ESTUARY } & \text { NOT GIVEN FURTRAN } & 70 \\ \text { SURFACE WAVE RAYS } & \text { IBM } 7094 & \text { FORTRAN II } & 105 \\ \text { TOTAL CO(2) } & \text { IBM } 7094 & \text { FURTRAN II } & 12\end{array}$

KANSAS, UNIVERSITY OF - STATE GEOLOGICAL SURVEY

AUTOMATIC CONTOURING

NOT GIVEN NOT GIVEN 34

CALCULATE AND PLOT TIME-TREND CURVES IBM7090/94FORTRAN, FAP 46

CROSS-ASSOCIATION OF SEQUENCES

MULTIVARIATE DISCRIMINANT ANALYSIS IBM7040/44FURTRAN IV, 54

POWER SPECTRUIM OF GEOLOGICAL SURFACE GE 625, FORTRAN IV 54

Q-MODE CLUSTER ANALYSIS

IBM 7040

IBM $360 / 67$,FORTRAN IV 55

SIMULATION OF DELTAIC SEDIMENTATION

IBM $7090 / 94$

SIMULATION OF MARINE SEDIMENTATION

IBM $360 / 67 F U R T R A N$ IV $-\mathrm{H} 34$

IBM 7040, FORTRAN IV 33

IBM $7090 / 94$

SIMULATION OF TRANSGRESSION IN TIME

CDC 6400 FORTRAN IV 54

IBM 1620 FORTRAN II 29

STANDARD-SIZE ANALYSIS OF SEDIMENTS

TREND ANALYSIS USING FOURIER SERIES

TREND-SURFACE WITH UNRESTRICTED I/P

GE 625

FURTRAN IV 55

IBM 1620 FORTRAN II, 47

TREND SURFACES DEGREES 1 TO 6

IBM 7040 FORTRAN IV

2-DIMENSIONAL REGRESSION

B5500, ALGOL,

IBM 7040 FORTRAN IV

VECTOR TREND ANAL. DIRECTIONAL DATA IBM7090/94FORTRAN IV

LAMONT GEOLOGICAL OBSERVATORY (COLUMBIA UNIVERSITY)

CORE INFORMATION

FOURIER ANALYSIS

REDUCTION, DISPLAY OF SEA DATA
NOT GIVEN FORTRAN 112

IBM 7090 FORTRAN 55

IBM 1130 FORTRAN $14,25,60$

MASSACHUSETTS INSTITUTE OF TECHNOLOGY

CURRENT METER DYNAMICS

DETRND, ETC. (SPECTRA SUBROUTINES)

LENGI (WAVE LENGTH AND SPEED)

MAGNETIC ANOMALIES AND GRADIENTS

PROF ILE

PROF 1 (WATER ELEV. OVER WAVE PERIOD)

REFLI (REFLECTED WAVE)

UMAX I, ETC. (MAX. FLOW VELOC.)

UOFTI, ETC. (FLOW VELOCITIES)

WAVE FORCE DISTRIBUTION

WAVE FORCES AND MOMENTS
IBM OS/36OMAC 72

IBM $360 / 4$ OFORTRAN IV 48

IBM 360/40FORTRAN IV 107

IBM 7094 FURTRAN I I 26

IBM 360/4UFORTRAN IV 108

IBM 360/40FORTRAN IV 108

IBM $360 / 4$ OFURTRAN IV 108

IBM 360/4OFORTRAN IV 109

IBM 360/4OFORTRAN IV 108

IBM7090/94FORTRAN IV 109

IBM7090/94FURTRAN IV 109 
ALKALINITY AND SPECIFIC ALKALINITY DYNAMIC HEIGHT CALCULATION

JOB EDIT FOR L-Z PROGRAM

OCEANO. DATA PLOTTING FOR ICES DATA

OCEANO. DATA PLOTTING FOR NODC DATA

OCEAN STA. CURVE PLOTTING FOR 1401

SALINITY VALUE CALCULATION

TEMPERATURE AND DEPTH CALCULATIONS
IBM 1620

IBM 1620

IBM 1401

IBM 1620

IBM 1620

IBM 1401

IBM 1620

IBM 1620 ,

IBM 1401
FORTRAN

FORTRAN II

AUTOCODER

FORTRAN II

FORTRAN II

AUTOCODER

FORTRAN

FORTRAN AND

AUTOCODER
09

90

21

43

43

38

09

16

$\begin{array}{lll}\text { IBM } 7090 & \text { MAD } & 81 \\ \text { IBM } 7090 & \text { MAD } & 93 \\ \text { IBM } 7090 & \text { MAD } & 65 \\ \text { IBM 7090 } & \text { MAD } & 65 \\ \text { IBM 7090 } & \text { MAD } & 47 \\ \text { IBM 7090 } & \text { MAD } & 68\end{array}$

AVG. TEMPERATURES IN WATER COLUMN DYNAMIC HEIGHT AND CURRENT DYNAMICS GENERAL MAP PROJECTION

MAP PROJECTION DISTORTIONS

TREND MAP, WITH RESIDUALS

WIND CURRENTS
NATIONAL ENGINEERING SCIENCE CO.

WAVE SHOALING
IBM 7040 FORTRAN

NATIONAL INSTITUTE OF OCEANOGRAPHY

ALPHA (SPECIFIC VOLUME)

BARTLETT'S CURVE FITTING

BIOLOGICAL STATION FILE

SRAINCON DATA REDUCTION

CABLE CONFIGURATION

CLUSTER ANALYSIS

CURRENT METER ANALYSIS

CURRENT METER CONVERSION

HILOW

HNAV (LORAN/DECCA COORDINATES CALC.) HNV 1 (LORAN/DECCA FILE)

POTLT (POTENTIAL TEMPERATURE)

Q FACTORS

SATELLITE NAVIGATION

SBWRO (WAVE RECORDER ANALYSIS)

SDANO (INVERSE GEODETIC)

SDVEL

SI GMO

SIGMT

STATION DATA (ATLAS)

THERMOMETER CORRECTIONS

TIDAL ANALYSIS AND PREDICTION

$2 D$ MAGNETIC ANOMALIES

VAPW (SATURATION VAPOR PRESSURE)
IBM 1800

IBM 1800

ATLAS I

IBM 1800

IBM 1800

IBM 1800

I BM 1800

IBM 1800

IBM 1800

IBM 1800

IBM 1800

IBM 1800

ATLAS 1

IBM 1800

IBM 1800

I BM 1800

IBM 1800

IBM 1800

IBM 1800

ATLAS I

MERCURY

MERCURY

IBM 1800

IBM 1800
FORTRAN

FORTRAN

EMA

FORTRAN IV 15

FORTRAN IV 73

FORTRAN $\quad 55$

FORTRAN IV 73

FURTRAN IV 73

FORTRAN IV 48

FORTRAN IV 63

FORTRAN IV 63

FORTRAN 85

FORTRAN V $\quad 15$

FORTRAN AND 58

ASSEMBLER

FORTRAN IV 48

FORTRAN IV 63

FORTRAN $\quad 102$

FORTRAN 85

FORTRAN 85

EMA 83

CHLF $3 / 4 \quad 15$

CHLF $3 / 4 \quad 104$

FURTRAN 26

FORTRAN IV 66

\section{NATIONAL OCEANOGRAPHIC DATA CENTER}

BATHYTHERMOGRAM COMPOSITE PLOT

BATHYTHERMOGRAPH DATA CONVERTER

BATHYTHERMOGRAPH OUTPUT

SIODETER IORAT ION

CONVERSION, NODC TO ICES

CRUISE TRACK

DENSITY-SALINITY LINEAR INTERPOL.

DENSITY-SALINITY MID PLOT

DEVIATION OF TEMP. AND SALIN. PART I IBM 7074

DRIFT BOTTLE DATA COMPUTATION

ERROR IN VERTICAL SOUND VELOCITY

GEOLOGICAL SAMPLE CONVERSION

GEOLOGICAL SAMPLING INVENTORY PLOT
IBM 7074

IBM 7074

IBM 1401

IBM 7074

IBM 1401

IBM 7074

IBM 7074

IBM 7074

IBM 7074

IBM 7074

IBM 7074

IBM 7074
FORTRAN

AUTOCODER

SPS

AUTOCODER

SPS

FORTRAN

FORTRAN

FORTRAN

AUTOCODER

AUTOCODER

FORTRAN

FORTRAN

FORTRAN

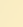
(2) 5 65
4 .

8


GRADIENT SUMMARY SY 1 -DEG SQ., MONTH INTERPOLATION OF OCEAN STAIION DATA INTERPOLATION SPECIFIC VOL ANOMALY INVENTORY PLOT

OCEAN STATION DATA OUTPUT, NODC

OCEAN STATION DEPTH SUMMARY

SALINITY DEVIATION PROGPLOT

SEA SENSE - DATA DISPLAY

SEA SENSE - LIMIT

SEA SENSE - STANDARD DEVIATION

SIGMA-T VS DEPTH, SALINITY (PLOT)

SOUND VELOCITY DEPTH PROFILES

STATION DATA COMPUTE

STA. DATA CONVERSION, COUC TO NODC

STATION DATA PARAMETER INVENTORY

STATION DATA PLOT - SIX VARIABLES

STATION DATA VERTICAL ARRAY SUMMARY

SUBROUTINE 'MAP '

SURFACE CURRENT SUMMARY

THERMOCLINE AND MIXED LAYER DEPTHS

THERMOM. CORR., THERMO. DEPTH

VERTICAL SECTION PLOT - STATION DATA

VERTICAL SUMMARY HISTOGRAM PLOT

$\begin{array}{llll}\text { IBM } 7074 & \text { AUTOCODER } & 76 \\ \text { IBM } 7074 & \text { FORTRAN } & 87 \\ \text { IBM } 7074 & \text { FURTRAN } & 83 \\ \text { IBM } 360 / 4 \text { OUUTRAN IV } & 41 \\ \text { IBM } 1401 & \text { SPS } & 23 \\ \text { IBM } 1401 & \text { SPS } & 82 \\ \text { IBM } 7074 & \text { FORTRAN } & 78 \\ \text { IBM } 7074 & \text { FORTRAN } & 80 \\ \text { IBM } 7074 & \text { FORTRAN } & 80 \\ \text { IBM } 7074 & \text { FURTRAN } & 80 \\ \text { IBM } 7074 & \text { FORTRAN } & 42 \\ \text { IBM } 7074 & \text { FORTRAN } & 42 \\ \text { IBM } 7074 & \text { AUTOCODER } & 82 \\ \text { IBM } 1401 & \text { SPS } & 24 \\ \text { IBM } 7074 & \text { FURTRAN } & 79 \\ \text { IBM } 7074 & \text { FORTRAN } & 42 \\ \text { IBM } 7074 & \text { AUTOCODER } & 78 \\ \text { IBM } 360 / 40 \text { FORTRAN IV } & 63 \\ \text { IBM } 7074 & \text { AUTOCODER } & 68 \\ \text { IBM } 7074 & \text { AUTOCODER } & 76 \\ \text { IBM } 7074 & \text { FORTRAN } & 17 \\ \text { IBM } 7074 & \text { FORTRAN } & 42 \\ \text { IBM } 7074 & \text { FORTRAN } & 41\end{array}$

NAVAL CIVIL ENGINEERING LABORATORY
CARBONATE-CARBON ANALYSIS OF SED。

IBM 1620 IIFORTRAN II-D CONSOLIDATION TESTS ON OCEAN SEDIMENTIBM $1620 I$ IFORTRAN II-D DIRECT SHEAR TEST ON OCEAN SEDIMENT IBM 1620 IIFORTRAN II-D ENG. INDEX PROP. OF CORE SAMPLES GRAIN SIZE ANALYSIS - PLOT AND TAB PERMEABILITY TEST ON OCEAN SED. SETTLEMENT ANALYSIS

SUMMARY PLOTS OF SED. TEST RESULTS TRIAXIAL COMPRESSION TEST
IBM 1620 IIFORTRAN II-D 29

IBM 1620 IIFORTRAN II-D 29

IBM 1620 I IFORTRAN II-D 30

IBM 1620 IIFORTRAN II-D 31

IBM 1620 IIFORTRAN II-D 31

IBM 1620 I IFORTRAN II-D 30

NAVAL ELECTRONICS LABORATORY CENTER

SEQUENTIAL PLOTTING

NOT GIVEN FORTRAN

44

NAVAL OCEANOGRAPHIC OFFICE

A IR-SEA

AN/UYK-I SOUND VELOCITY

ASTRONOMIC LATITUDE

BATHYMETRIC DATA REDUCTION

BOTTOM REFLECTION ANALYSIS

BOTTOM SEDIMENT DISTRIBUTION PLOT

BT ANALYSIS (S.E.R.C. DATA)

BT TEMPERATURE GRADIENT DISTRIBUTION CIRAZD (DISTANCE-AZIMUTH CALC.)

CIRCULAR CHARTING

CLOUD COVER AND DAILY SEA TEMPERATURE COMPUTE ADVECTION

CONVERGENCE ZONE RANGE

CRITICAL ACOUSTIC RATIO

CURRENT METER TURBULENCE

DENSITY GRADIENT BY I-DEGREE SQUARE FAA PLOT

GENERAL PURPOSE PLOT

GEODETIC DATUM CONVERSION

GEODETIC DATUM REDUCTION

GEODETIC POSITION COMP. AND PLOT

GRIDIT, REGRIDIT, AUTOMATED CONTOUR

GULF STREAM PATH

ICE POTENTIAL

LAYER DEPTH PLOT

$\begin{array}{llr}\text { IBM } 7074 & \text { FORTRAN } & 66 \\ \text { AN/UYK-1 } & \text { LOGANDS } & 103 \\ \text { NOT GIVEN } & \text { FORTRAN } & 60 \\ \text { IBM } 7074 & \text { FURTRAN } & 18 \\ \text { IBM } 7074 & \text { FORTRAN } & 98 \\ \text { IBM } 7074 & \text { FORTRAN } & 33 \\ \text { IBM } 7074 & \text { AUTOCODER } & 76 \\ \text { IBM } 7074 & \text { FORTRAN } & 76 \\ \text { IBM } 7074 & \text { FORTRAN } & 61 \\ \text { IBM 7074 } & \text { FORTRAN } & 61 \\ \text { IBM 7074 } & \text { FORTRAN } & 66 \\ \text { IBM } 1401 & \text { FORTRAN } & 69 \\ \text { IBM } 7074 & \text { FORTRAN } & 98 \\ \text { IBM 7074 } & \text { FORTRAN } & 98 \\ \text { IBM } 7074 & \text { FORTRAN } & 72 \\ \text { IBM 7074 } & \text { FORTRAN } & 78 \\ \text { IBM 7074 } & \text { FORTRAN } & 35 \\ \text { IBM 7074 } & \text { FURTRAN } & 37 \\ \text { IBM 7074 } & \text { FORTRAN } & 61 \\ \text { IBM 7074 } & \text { FORTRAN } & 61 \\ \text { IBM } 7074 & \text { FORTRAN } & 62 \\ \text { NOT GIVEN } & \text { FORTRAN } & 34 \\ \text { IBM 7074 } & \text { FORTRAN } & 69 \\ \text { IBM 7074 } & \text { FORTRAN } & 75 \\ \text { IBM 7074 } & \text { FORTRAN } & 66\end{array}$


LEAST SQUARES PLOT

LIGHT AND SOUND INSTRUCTION B

LIGHT AND SOUND INSTRUCTION D

LORAN A AND C SKYWAVE

LORAN - COORDINATE COMPUTATION

LORAN EDIT

LORAN TO GEOGRAPHIC CONVERSION

MARINE BIOLOG. ENVIRON. SUMMARIES

MARSDEN SQ. AVERAGES FROM GEOFILE

MASS PHYSICAL PROPERTIES

MODIFIED SURFACE CURRENTS

MONTHLY SONIC LAYER DEPTH

OBSERVATION DRAPING (GRAVITY)

OXYGEN SATURATION

PARAMETRIC MAP

POINT GENERATOR FOR DISTANCE-AZIMUTH POINT GENERATOR FOR MAP PROJECTIONS PREDICTION OF VERTICAL TEMP. CHANGE RAY PATH

SALINITY - CONDUCTIVITY FORMULA

SALINITY GRADIENT BY 1-DEGREE SQUARE SEA SURFACE TEMPERATURE DISTR+BUTION

SEAMOUNT MAGNETIZATION

SEDIMENT SIZE

SHIPBOARD SURVEY -- ON-STATION MODE

SHIPBOARD SURVEY -- ON-STATION PLOT

SINGLE INTEGRATION

SODANO INVERSE

SOLAR RADIATION CONVERSION

SOUND SPEED EDIT

SOUNDING PLOT

STANDARD-VECTOR DEVIATION ROSE STATISTICAL ANALYSIS OF ICE DATA STATISTICAL SURFACE CURRENT ROSE SVLIM (SOUND VELOCITY RETRIEVAL) TAPE INPUT AND OUTPUT SUBROUT+NE TEMPERATURE AVG. SUMMARY BY 1-DEG TEMPERATURE DISTRIBUTION BY 1-DEG SQ. THERMOCLINE ONE-DEGREE

2-DIMENSION POWER SPECTRUM (SWOP II)

VAM INTERPOLATION II

VERTICAL TEMPERATURE GRADIENTS

WIND STRESS

NAVAL POSTGRADUATE SCHOOL

BLACKY (TIMESERIES ANALYSIS)

CURRENT

ICEGRID MODIFIED

OBJECTIVE THERMOCLINE ANALYSIS

SONOBUOY FIXING ERROR

SPECIFIC CONDUCTIVITY

TIDES

VC2AP 3 SHIP ROUTING

WAVES GENERATED BY TURBULENT WIND
IBM 7074

IBM 7074

IBM 7074

IBM 7074

IBM 7074

IBM 7074

IBM 7074

IBM 7074

IBM 7074

IBM 7074

IBM 7074

IBM 7074

IBM 7074

IBM 7074

IBM 7074

IBM 7074

IBM 7074

IBM 7074

IBM 7074

IBM 7074

IBM 7074

IBM 7074

IBM 7074

IBM 7074

IBM 7074

IBM 7074

IBM 7074

CDC 3100

I BM 7074

IBM 7074

CDC 3100 ,

IBM 7074

IBM 7074

IBM 7074

IBM 7074

CDC 3100

IBM 7074

I IBM 7074

IBM 7074

IBM 7074

IBM 7074

IBM 7074

IBM 7074

IBM 7074
FORTRAN

FORTRAN

FORTRAN

FORTRAN

FORTRAN

FORTRAN

FORTRAN

FORTRAN

FORTRAN

FORTRAN

AUTOCODER

FORTRAN

FORTRAN

FORTRAN

FORTRAN I I 64

FORTRAN II 64

FORTRAN II 63

FORTRAN $\quad 66$

FORTRAN 98

FORTRAN 12

FURTRAN 78

FORTRAN $\quad 77$

FORTRAN 27

FORTRAN 28

FORTRAN $\quad 87$

FORTRAN $\quad 37$

FORTRAN $\quad 57$

FORTRAN 60

FORTRAN 27

FORTRAN 22

FORTRAN 35

FORTRAN 69

FORTRAN $\quad 75$

AUTOCODER 69

FURTRAN II 101

AUTOCODER 21

FORTRAN $\quad 77$

FORTRAN $\quad 77$

AUTOCODER $\quad 78$

FORTRAN 67

FORTRAN 27

FORTRAN $\quad 77$

FORTRAN $\begin{array}{lll}\text { IBM OS/36OFORTRAN IV } & 49 \\ \text { IBM OS/36OFORTRAN IV } & 56 \\ \text { CDC } 1604 \text { FORTRAN-6O } & 74 \\ \text { CDC } 6500, \text { FORTRAN IV-H } & 75 \\ \text { IBM OS/360 } & \\ \text { NOT GIVEN FORTRAN } & 99 \\ \text { IBM OS/36OFORTRAN } & 11 \\ \text { NOT GIVEN FORTRAN-60 } & 105 \\ \text { CDC 1604 FORTRAN } & 106 \\ \text { IBM 360/67FORTRAN } & 106\end{array}$

NAVAL RESEARCH LABORATORY

ACOUSTIC RAY TRACING

BLACKBODY RADIANCE

BLACKBODY SPECTRAL RADIANCE

DATUBA (BUOY-CABLE DEFLECT.)

DETERMINANT OF A SYMMETRIC MATRIX

DISTANCE BETWEEN TWO POINTS

EVALUATE BESSEL FUNCTIONS

FIND REAL ZEROS OF FUNCTION

$\begin{array}{llll}\text { CDC } 3800 & \text { FORTRAN-63 } & 96 \\ \text { CDC } 3800 & \text { FORTRAN } & 25 \\ \text { CDC } 3800 & \text { FORTRAN } & 25 \\ \text { CDC } 3800 & \text { FORTRAN-63 } & 72 \\ \text { CDC } 3800 & \text { FORTRAN } & 53 \\ \text { CDC } 3800 & \text { FORTRAN } & 59 \\ \text { CDC } 3800 & \text { FORTRAN } & 53 \\ \text { CDC } 3800 & \text { FORTRAN } & 53\end{array}$


NELED IT

PROPAGATION LOSS - NORMAL MODES

CDC 3800

$\operatorname{CDC} 3800$

CDC 3800

RAY TRACING

RAY TRACE PROCESSING

SCALING SUBROUTINE

CDC 3800

CDC 3800

SOUND SPEED PROFILES - NORMAL MODES

THREE-DIMENSIONAL SURFACE PLOTS

CDC 3800

CDC 3800

UTILITY

$\operatorname{CDC} 3800$

TRAN

FORTRAN-63

FORTRAN,

COMPASS

FORTRAN

NAVAL RESEARCH LABORATORY, ORLANDO

NEAR-FIELD ARRAY TESTING

PDP-8 FORTRAN

NAVAL SHIP RESEARCH AND DEVELOPMENT CENTER

DIGITAL POWER SPECTRUM ANALYSIS

LONG. STRENGTH OF SHIP HULL

PARTIAL AND ORDINARY COHERENCE

POWER SPECTRUM ANALYSIS

PROJECT COD LIVER

SAVED (BLAST TEST DATA REDUCTION)

STATISTICAL AND PEAK-TO-PEAK ANAL.
FORTRAN IV

FORTRAN IV FORTRAN IV

AND MAP

IBM 7090, FORTRAN

IBM 704

I BM 7090

IBM 7090

IBM 7090

IBM 7090
IBM 7090
IBM 7090

FORTRAN II

AND MAP

FORTRAN IV

AND MAP

FORTRAN IV

AND MAP
48

110

49

50

50

58

$\operatorname{CDC} 3200$

CDC 3200

CDC 3200
FORTRAN

FORTRAN

FORTRAN
58

59

NAVAL UNDERSEA RESEARCH AND DEVELOPMENT CENTER, PASADENA

NEWF IT

PATTERN FUNCTION CALCULATIONS

RAYMOR

RAY SORT

SONAR IN REFRACTIVE WATER
UNIVACIIOBFORTRAN IV 95 UNIVACIIOBFORTRAN IV 95 UNIVACI1 OBFORTRAN V 95 UNIVACIIOBFORTRAN IV 95 UNIVACIIOBFORTRAN IV 94

NAVAL UNDERSEA RESEARCH AND DEVELOPMENT CENTER, SAN DIEGO

FATHOMETER CORRECTION

CDC 1604 FORTRAN

NAVAL UNDERWATER WEAPONS RESEARCH AND ENGINEERING STATION

INTERPOLATION FOR OCEANOGRAPHIC DATA CDC 3200 , FORTRAN 
RAY TRACING

SOUND VELOCITY IN OCEAN WATER

NAVY WEATHER RESEARCH FACILITY

OPTIMUM TRACK SHIP ROUTING

NEW YORK UNIVERSITY

FILM DATA PROCESSING

CDC 1604 FORTRAN-SO

72

NORTHWESTERN UNIVERSITY

CIRCSTAT

CDC 3400 FORTRAN IV

52

PACIFIC NAVAL LABORATORY, CANADA

POWER SPECTRUM ANALYSIS
IBM 704 FORTRAN II 99 IBM 704 FURTRAN II 102
PB-440, MACHINE, UNIVACIIO7FORTRAN IV

106 
SALINE WATER, OFFICE OF

OPTIMIZATION OF VTE WATER PLANTS

IBM 7094 FORTRAN IV

12

SCRIPPS INSTITUTION OF OCEANOGRAPHY

BIOP (BIOLOGY PLOT)

BOMM (TIME SERIES)

CADS (CALC. DEPENDENT QUANTITIES) CHLOR

GO (POT. TEMP., SIGMA THETA, OXY.)

HYPERMAP

NUTRIENT CHEMISTRY CONCENTRATION

OCEAN STATION COMPUTATIONS

PRIMARY PRODUCTIVITY

PROFL

RADIATION ATTENUATION

PROGRAM REGROUP

S.T.D. DATA PROCESSING

TWO FIVE (DATA REDUCTION)

WATERVEL (SOUND VELOCITY)

ZOOPLANKTON VOLUME

\section{STANFORD UNI VERSITY}

REFRACTION OF WAVES

SIMULATION OF WIND-GENERATED WAVES

$\begin{array}{llll}\text { CDC } 3600 & \text { FORTRAN IV } & 33 \\ \text { IBM } 05 / 360 \text { FORTRAN, } & 52 \\ \text { CDC } 3600 & \text { COMPASS } & \\ \text { IBM } 1800 & \text { FORTRAN IV } & 84 \\ \text { CDC } 3600 & \text { FORTRAN IV } & 08 \\ \text { IBM } 1800 & \text { FORTRAN IV } & 85 \\ \text { NOT GIVEN } & \text { FORTRAN } & 64 \\ \text { CDC } 1604 & \text { (NOT GIVEN) } & 08 \\ \text { CDC } 1604 & \text { (NOT GIVEN) } & 93 \\ \text { CDC } 1604 & \text { (NOT GIVEN) } & 08 \\ \text { CDC } 3600 & \text { FORTRAN IV } & 38 \\ \text { CDC } 1604 & \text { (NOT GIVEN) } & 94 \\ \text { CDC } 3600 & \text { FORTRAN } & 07 \\ \text { CDC } 3600 & \text { FORTRAN IV } & 17 \\ \text { CDC } 3600, & \text { FORTRAN-63, } & 17 \\ \text { IBM } 1800 & \text { FORTRAN IV } \\ \text { NOT GIVEN FORTRAN } & 102 \\ \text { CDC } 1604 & \text { (NOT GIVEN) } & 08\end{array}$

IBM7090/94FORTRAN IV 110 IBM7090/94FORTRAN IV 111

\author{
TEXAS A. AND M. UNIVERSITY \\ OCEANOGRAPHIC DATA PROGRAM F \\ RADIATION TEMP. OF SEA SURFACE \\ SEISMIC SLOPING LAYER \\ S.T.D. CORRECTION \\ TEXAS, UNIVERSITY OF \\ ECOPROD \\ JOB (SPECIES DIVERSITY) \\ OXYGEN
}

VELOCITY, HORIZ. EDDY COEFFIFIENTS

$\begin{array}{lllll}\text { IBM } 7094 & \text { FORTRAN } & & 87 \\ \text { NOT GIVEN } & \text { FORTRAN } & & 68 \\ \text { IBM } 709 & \text { FORTRAN I I } & 27 \\ \text { IBM } 7094 & \text { FORTRAN IV } & 19 \\ \text { IBM } 709 & \text { FURTRAN } & & 70\end{array}$

$\begin{array}{llll}\text { CDC } 6600 & \text { FORTRAN IV } & 05 \\ \text { CDC } 6600 & \text { FORTRAN IV } & 06 \\ \text { CDC } 6600 & \text { FORTRAN IV } & 06\end{array}$

TORONTO, UNIVERSITY OF

TIME TERM, SEISMIC REFRACTION INTERP.IBM 7094 FORTRAN IV 27

TRANSPORTATION, DEPARTMENT OF (SEE COAST GUARD...)

WASHINGTON, UNIVERSITY OF

BKGEOL (SEDIMENT STATISTICS)

CHLOROPHYLL AND PRODUCTIVITY

CONCENTRATIONS PER SQUARE METER

DEAD RECKONING NAVIGATION SYSTEM

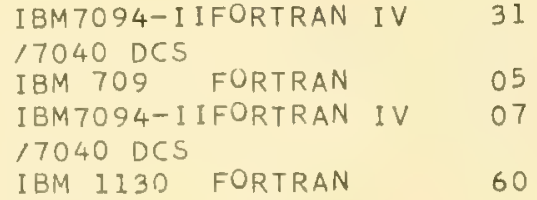


INTERPOLATION PROGRAM

PHYTOPLANKTON NUMBERS, ETC.

SDGVEL (SOUNDING CORRECTION)

SEDIMENT GRANULOMETRIC ANALYSIS

SPECIAL CHEMISTRY CALCULATIONS

S.T.D. CALCULATIONS

S.T.D. EDIT AND INTERPOLATE

SYNOPTIC PROGRAM

UNDERWAY DATA SYSTEM

WISCONSIN, UNIVERSITY OF

SEICHE ANALYSIS

SPECTRAL ANALYSIS OF TIME SERIES
CDC 6400 FORTRAN IV 90

IBM7094-I IFORTRAN IV 07

17040 DCS

IBM7094-IIFORTRAN IV 102

17040 DCS

IBM7094-I IFORTRAN IV 32

17040 DCS

IBM 1130 FORTRAN IV O9

IBM 1130 FORTRAN IV, 18

IBM 1130 FORTRAN 86

IBM7094-IIFORTRAN II 18,90

17040 DCS,

CDC 6400

IBM 1130 FORTRAN 18

IBM $360 / 50 A L G O L, \quad 107$

B5500, ALGOL 60, 50

UNIVACIIOBFORTRAN IV

WOODS HOLE OCEANOGRAPHIC INSTITUTION

ATG IADIABATIC TEMPERATURE GRADIENT BETA-MODEL WITH WHITE FORCING CRVFT (LEAST SQUARES FIT)

DATA

DSTABF (STABILITY FREQUENCY)

DYNHT (DYNAMIC HEIGHTS)

GRAIN SIZE

HISTO (HISTOGRAM PLOT)

HYLOG (HYDRO. STA. DATA REDUCTION)

LISPLO (LIST AND PLOT)

NUSPEC (SPECTRUM ESTIMATION)

OCCOMP (OCEANOGRAPHIC COMPUTE)

ORD 1 (OLMSTED RAY DIAGRAM NO. I)

ORD 2 (OLMSTED RAY DIAGRAM NO. 2)

PEN (POTENTIAL ENERGY ANOMALY)

POTEMP (POTENTIAL TEMPERATURE)

\section{PRESS}

PROVEC (PROGRESSIVE VECTORS)

SCRUB (DATA EDIT AND CORRECT)

SI GMAT

SONVEL (SOUND VELOCITY)

SPVOL

STATS (STATISTICAL QUANTITIES)

SVANOM (SPECIFIC VOLUME ANOMALY)

THISTO (TWO-DIMEN . FREQ. DISTRIB.)

THRCL (THERMOMETER CALIBRATION)

VECTAV (VECTOR' AVERAGES)

VEL (GEOSTROPHIC VELOCITY)

VFREQ (VAISALA FREQUENCY COMP.)

VTR (VOLUME TRANSPORT)

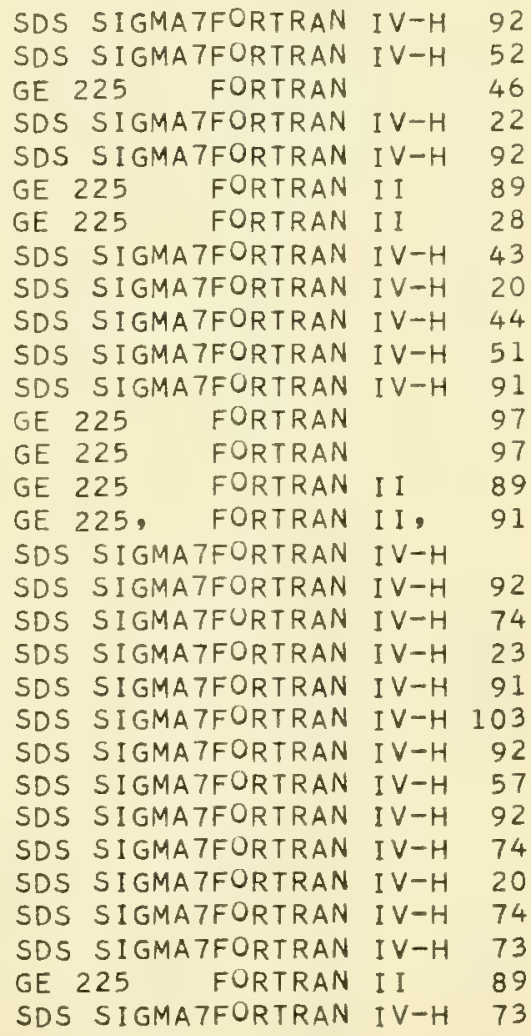

SDS SIGMATFORTRAN I V-H 92

46

SDS SIGMATFORTRAN IV-H 22

SDS SIGMA7FORTRAN IV-H 92

GE 225 FORTRAN I I 89

GE 225 FORTRAN II 28

SDS SIGMA7FORTRAN IV-H 43

SDS SIGMATFORTRAN IV-H 20

SDS SIGMATFORTRAN IV-H 44

SDS SIGMATFORTRAN IV-H $5 I$

SDS SIGMATFORTRAN IV-H 91

GE 225 FORTRAN

GE 225 FORTRAN

GE 225 FORTRAN I I 89

GE 225, FORTRAN II, 91

SDS SIGMATFORTRAN IV-H 92

SDS SIGMATFURTRAN IV-H 74

SDS SIGMATFORTRAN IV-H 23

SDS SIGMATFORTRAN IV-H 91

SDS SIGMATFORTRAN IV-H 103

SDS SIGMATFORTRAN IV-H 92

SDS SIGMATFORTRAN IV-H 57

SDS SIGMATFORTRAN IV-H 92

SDS SIGMATFORTRAN IV-H 74

SDS SIGMATFORTRAN IV-H 20

SDS SIGMATFORTRAN IV-H 73

SDS SIGMATFORTRAN IV-H 73 

ALGOL, BALGOL

2-DIMENSIONAL REGRESSION

SEICHE ANALYSIS

SPECTRAL ANALYSIS OF TIME SERIES

CROSS-ASSOCIATION OF SEQUENCES

TREND-SURFACE WITH UNRESTRICTED I/P

\section{0}

IBM $360 / 50 A L G O L$

B5500 ALGOL 60

ELLIOTT803ALGOL 60

IBM 1620 BALGOI.
45

107

50

54

47

\section{AUTOCODER}

JOB EDIT FOR L-Z PROGRAM

OCEAN STA. CURVE PLOTTING FOR 1401

TEMPERATURE AND DEPTH CALCULATIONS

BATHYTHERMOGRAPH DATA CONVERTER

BIODETERIORATION

DEVIATION OF TEMP. AND SALIN. PART 1

DRIFT BOTTLE DATA COMPUTATION

GRADIENT SUMMARY BY 1-DEG SQ., MONTH

MODIFIED SURFACE CURRENTS

BT ANALYSIS (S.E.R.C. DATA)

STATION DATA COMPUTE

STATION DATA VERTICAL ARRAY SUMMARY

STATISTICAL SURFACE CURRENT ROSE

SURFACE CURRENT SUMMARY

TAPE INPUT AND OUTPUT SUBROUTINE

THERMOCLINE AND MIXED LAYER DEPTHS

THERMOCLINE ONE-DEGREE
I BM 1401

IBM 1401

IBM 1401

IBM 7074

IBM 7074

IBM 7074

IBM 7074

IBM 7074

IBM 7074

I BM 7074

IBM 7074

IBM 7074

IBM 7074

IBM 7074

IBM 7074

IBM 7074

IBM 7074
AUTOCODER

AUTOCODER

AUTOCODER

AUTOCODER

AUTOCODER

AUTOCODER

AUTOCODER

AUTOCODER

AUTOCODER

AUTOCODER

AUTOCODER

AUTOCODER

AUTOCODER

AUTOCODER

AUTOCODER

AUTOCODER

$A \cup T O C O D E R$
21

38

16

82

06

75

70

76

68

76

82

78

69

68

21

76

78

DECAL

RICHARDSON CURRENT METER FILM READ. THE VORTEX OCEAN MODEL

WORLD OCEANO. DATA DISPLAY

PDP $-7(9)$ $P D P-7(9)$

PDP-7 (9)

DECAL

DECAL

DECAL
15

38

38

\section{FORTRAN}

FATHOMETER CORRECTION

$\operatorname{CDC} 1604$

FORTRAN

101

MACHINE PLOTTING ON MERCATOR PROJ.

VC2AP 3 SHIP ROUTING

CDC 1604

CDC 1604

FORTRAN

FORTRAN

CDC 3100

FORTRAN

FORTRAN

SODANO INVERSE

SOUNDING PLOT

TEMPERATURE-SALINITY PLOT

CDC 3100

CDC 3100

FORTRAN

CDC 3100

FORTRAN

CDC 3200

CDC 3200

FORTRAN

FORTRAN

CDC 3200

SPANSIA (BEACON POSITION)

FORTRAN

FORTRAN

FORTRAN

$\operatorname{CDC} 3200$

POWER SPECTRA ESTIMATION

SOUND VELOCITY

PROGRAM REGROUP

BLACKBODY RADIANCE

BLACKBODY SPECTRAL RADIANCE

DETERMINANT OF A SYMMETRIC MATRIX

DISTANCE BETWEEN TWO POINTS

EVALUATE BESSEL FUNCTIONS

FIND REAL ZEROS OF FUNCTION

GREAT CIRCLE PATHS FROM A POINT

GREAT CIRCLE RETRIEVAL

LINE PRINTER PLOTS

NELEDIT

PROPAGATION LOSS - NORMAL MODES

SCAL ING SUBROUTINE

THREE-DIMENSIONAL SURFACE PLOTS

CDC 3200

$\operatorname{CDC} 3600$

CDC 3800

CDC 3800

CDC 3800

$\operatorname{CDC} 3800$

CDC 3800

$\operatorname{CDC} 3800$

CDC 3800

CDC 3800

CDC 3800

CDC 3800

CDC 3800

FORTRAN

FORTRAN

FORTRAN

FORTRAN

FORTRAN

FORTRAN

FORTRAN

FORTRAN 
CRVFT

GE 225

ORD I (OLMSTED RAY DIAGRAM NO. 1)

GE 225

ORD 2 (OLMSTED RAY DIAGRAM NO. 2)

GE 225

DEEP (S.T.D. DIGITIZING)

HP $2115 \mathrm{~A}$

HP $2115 \mathrm{~A}$

ANAL. OF NON-LINEAR RESPONSE SURFACESIBM 1130

DEAD RECKONING NAVIGATION SYSTEM

IBM 1130

REDUCTION, DISPLAY OF SEA DATA

IBM 1130

S.T.D. EDIT AND INTERPOLATE

UNDERWAY DATA SYSTEM

IBM 1130

IBM 1130

IBM 1401

COMPUTE ADVECTION

IBM 1620

INTERPOLATION FOR OCEANOGRAPHIC DATA IBM 1620

SALINITY VALUE CALCULATION

IBM 1620

IBM 1620

TEMPERATURE AND DEPTH CALCULATIONS

IBM 1620

THERMOCHECK II - TEMP - CORRECTION

I BM 1620

IBM 1800

ALPHA (SPECIFIC VOLUME)

BARTLETT'S CURVE FITTING

CLUSTER ANALYSIS

POTLT (POTENTIAL TEMPERATURE)

I BM 1800

I BM 1800

IBM 1800

IBM 1800

SATELLITE NAVIGATION

SDVEL

SI GMO

SI GMT

IBM 1800

I BM 1800

IBM 1800

IBM 1800

IBM 7040

WAVE SHOALING

A I R-SEA

IBM 7074

IBM 7074

I BM 7074

IBM 7074

IBM 7074

BATHYTHERMOGRAM COMPOSITE PLOT

BOTTOM REFLECTION ANALYSIS

$\begin{array}{lll}\text { BT TEMPERATURE GRADIENT DISTRIBUTION } & \text { IBM } 7074 \\ \text { CIRAZD (DISTANCE-AZIMUTH CALC.) } & \text { IBM } 7074\end{array}$

CIRCULAR CHARTING

IBM 7074

CLOUD COVER AND DAILY SEA TEMPERATUREIBM 7074

CONVERGENCE ZONE RANGE

CRITICAL ACOUSTIC RATIO

CRUISE TRACK

CURRENT METER TURBULENCE

DENSITY GRADIENT BY 1-DEGREE SQUARE

DENSITY-SALINITY LINEAR INTERPOL.

DENSITY-SALINITY MID PLOT

ERROR IN VERTICAL SOUND VELOCITY

FAA PLOT

GENERAL PURPOSE PLOT

GEODETIC DATUM CONVERSION

GEODETIC DATUM REDUCTION

GEODETIC POSITION COMP. AND PLOT

GEOLOGICAL SAMPLE CONVERSION

GEOLOGICAL SAMPLING INVENTORY PLOT

GULF STREAM PATH

ICE POTENT IAL

INTERPOLATION OF OCEAN STATION DATA

INTERPOLATION SPECIFIC VOL ANOMALY

LAYER DEPTH PLOT

LEAST SQUARES PLOT

LIGHT AND SOUND INSTRUCTION B

LIGHT AND SOUND INSTRUCTION D

LORAN A AND C SKYWAVE

LORAN - COORDINATE COMPUTATION

LORAN EDIT

LORAN TO GEOGRAPHIC CONVERSION

MARINE BIOLOG. ENVIRON. SUMMARIES

MARSDEN SQ. AVERAGES FROM GEOFILE

MASS PHYSICAL PROPERTIES

MONTHLY SONIC LAYER DEPTH

IBM 7074

IBM 7074

I BM 7074

IBM 7074

IBM 7074

IBM 7074

IBM 7074

IBM 7074

IBM 7074

IBM 7074

IBM 7074

IBM 7074

IBM 7074

IBM 7074

IBM 7074

IBM 7074

IBM 7074

IBM 7074

IBM 7074

IBM 7074

IBM 7074

IBM 7074

IBM 7074

IBM 7074

IBM 7074

IBM 7074

IBM 7074

IBM 7074

IBM 7074

IBM 7074

IBM 7074

FURTRAN

FORTRAN

FORTRAN

FORTRAN

FORTRAN

FORTRAN

FORTRAN

FORTRAN

FORTRAN

FORTRAN

FORTRAN 14,25,60

FORTRAN 86

FORTRAN 18

FORTRAN 69

FORTRAN 09

FORTRAN 83

FORTRAN

FORTRAN 16

FORTRAN 17

FORTRAN 102

FORTRAN 85

FORTRAN 46

FURTRAN

FURTRAN 85

FORTRAN 58

FORTRAN 102

FORTRAN 85

FORTRAN 85

FORTRAN 26

$\begin{array}{lr}\text { FORTRAN } & 107 \\ \text { FORTRAN } & 66\end{array}$

FORTRAN

FORTRAN

FURTRAN

FORTRAN

FORTRAN

FORTRAN

FORTRAN

FORTRAN

FORTRAN

FORTRAN

FORTRAN

FORTRAN

FORTRAN

FORTRAN

FORTRAN

FORTRAN

FURTRAN

FORTRAN

FORTRAN

FORTRAN

FURTRAN

FORTRAN

FORTRAN

FORTRAN

FORTRAN

FORTRAN

FORTRAN

FORTRAN

FORTRAN

FORTRAN

FORTRAN

FURTRAN

FORTRAN

FORTRAN

FORTRAN

FORTRAN

FORTRAN

FORTRAN

FORTRAN

FORTRAN
18

41

98

33

76

61

61

66

98

98

41

72

78

86

42

101

35

37

61

61

62

28

33

69

75

87

83

66

46

102

98

62

62

21

62

06

79

28

77 
OBSERVATION DRAPING (GRAVITY)

OXYGEN SATURATION

PREDICTION OF VERTICAL TEMP. CHANGE RAY PATH

SALINITY - CONDUCTIVITY FORMULA

SALINITY DEVIATION PROGPLOT

IBM 7074

IBM 7074

IBM 7074

IBM 7074

IBM 7074

IBM 7074

SALINITY GRADIENT BY 1-DEGREE SQUARE IBM 7074

SEA SURFACE TEMPERATURE DISTRIBUTION

SEA SENSE - DATA DISPLAY

SEA SENSE - LIMIT

SEA SENSE - STANDARD DEVIATION

SEAMOUNT MAGNETIZATION

SEDIMENT SIZE

SHIPBOARD SURVEY -- ON-STATION MODE SHIPBOARD SURVEY -- ON-STATION PLOT

SIGMA-T VS DEPTH, SALINITY (PLOT)

SINGLE INTEGRATION

SOLAR RADIATION CONVERSION

SOUND SPEED EDIT

SOUND VELOCITY DEPTH PROFILES

SOUNDING PLOT

STANDARD-VECTOR DEVIATION ROSE

STATION DATA PARAMETER INVENTORY

STATION DATA PLOT - SIX VARIABLES

STATISTICAL ANALYSIS OF ICE DATA

IBM 7074

IBM 7074

IBM 7074

IBM 7074

IBM 7074

IBM 7074

IBM 7074

IBM 7074

IBM 7074

IBM 7074

IBM 7074

IBM 7074

IBM 7074

IBM 7074

IBM 7074

IBM 7074

IBM 7074

IBM 7074

TEMPERATURE AVG. SUMMARY BY I-DEG SQ. IBM 7074

TEMPERATURE DISTRIBUTION BY 1-DEG SQ.IBM 7074

THERMOM. CORR., THERMO. DEPTH

IBM 7074

2-DIMENSION POWER SPECTRUM (SWOP II) IBM 7074

VAM INTERPOLATION II

IBM 7074

VERTICAL SECTION PLOT - STATION DATA IBM 7074

VERTICAL SUMMARY HISTOGRAM PLOT

IBM 7074

VERTICAL TEMPERATURE GRADIENTS

WIND STRESS

VELOCITY, HORIZ. EDDY COEFFIFIENTS

IBM 7074

IBM 7074

IBM 709

FORTRAN

FORTRAN

25

FURTRAN

11

FORTRAN

FORTRAN 12

FORTRAN $\quad 78$

FURTRAN 78

FORTRAN $\quad 77$

FURTRAN 80

FORTRAN 80

FURTRAN 80

FORTRAN 27

FORTRAN 28

FURTRAN 87

FORTRAN $\quad 37$

FURTRAN $\quad 42$

FORTRAN $\quad 57$

FORTRAN 27

FORTRAN 22

FURTRAN 42

FORTRAN 35

FORTRAN 69

FORTRAN 79

FORTRAN 42

FORTRAN 75

FORTRAN $\quad 77$

FORTRAN $\quad 77$

FORTRAN 17

FORTRAN $\quad 67$

FORTRAN 27

FORTRAN 42

FORTRAN 41

FOURIER ANALYSIS

POWER SPECTRUM ANALYSIS

FORTRAN 77

IBM 7090, FORTRAN 55

TWO-DIMENSIONAL AUTOCORRELATION

IBM 704

IBM 7090, FORTRAN 56

CALCULATE AND PLOT TIME-TREND CURVES IBM7090/94FORTRAN, FAP 46

OCEANOGRAPHIC DATA PROGRAM F

WAVEIN AND DIFRAK

BOMM (TIME SERIES)

SPECIFIC CONDUCTIVITY

WAVES GENERATED BY TURBULENT WIND

DECCA HI-FIX

IBM 7094 FORTRAN

IBM 7094 FORTRAN

IBM O5/36OFORTRAN

IBM OS/36OFORTRAN

IBM 360/67FORTRAN

PDP $-5,85$ FORTRAN

INDUCT IVE SALINOMETER SALINITY CONV. NEAR-FIELD ARRAY TESTING

PDP-5, 85 FORTRAN

PDP-8 FORTRAN

87

RETRIEVAL OF GEOPHYSICAL DATA

SALINITY DISTRIBUTION IN ESTUARY

CORE INFORMATION

ASTRONOMIC LATITUDE

GRIDIT, REGRIDIT, AUTOMATED CONTOUR HYPERMAP

RADIATION TEMP. OF SEA SURFACE

RAY TRACING

SEDIMENT TEXTURAL ANALYSIS

SEQUENTIAL PLOTTING

SONOBUOY FIXING ERROR

WATERVEL (SOUND VELOCITY)

DATA REDUCTION FOR THE CDC 3100

ISALBP (SALINITY ANOMALY)

ISATBP (OXYGEN ANOMALY AND SAT.)

LEAST SQUARES CURVE FITTING

PLOT STATION POSITIONS

PLOT THETA-S CURVES

SVLIM (SOUND VELOCITY RETRIEVAL)

OCEANOGRAPHIC DATA COMPUTATION

NOT GIVEN FURTRAN

NOT GIVEN FORTRAN

NOT GIVEN FURTRAN

NOT GIVEN FORTRAN

NOT GIVEN FORTRAN

NOT GIVEN FORTRAN

NOT GIVEN FORTRAN

NOT GIVEN FORTRAN

NOT GIVEN FORTRAN

NOT GIVEN FORTRAN

NOT GIVEN FORTRAN

NOT GIVEN FORTRAN

50,110

52

11

106

64

11

99

112

70

112

60

34

64

68

97

32

44

99

CDC 3100 FORTRAN I 140

CDC 3100 FORTRAN I 14,83

CDC 3100 FORTRAN I I 10

CDC 3100 FORTRAN II 45

CDC 3100 FORTRAN II 36

CDC 3100 FORTRAN II 35

CDC 3100 FORTRAN II 101

CDC 6400 FORTRAN II 90

SEDIMENT DATA

$\operatorname{CDC} 6400$

FURTRAN II

29 
SYNOPTIC PROGRAM

STADAT 2

DYNHT (DYNAMIC HEIGHTS)

GRAIN SIZE

PEN (POTENTIAL ENERGY ANOMALY)

POTEMP (POTEN:T IAL TEMPERATURE)

VFREQ (VAISALA FREQUENCY COMP • )

DYNAMIC HEIGHT CALCULATION

MULTIVARIATE DISCRIMINANT ANALYSIS

OCEANO. DATA PLOTTING FOR ICES DATA

OCEANO. DATA PLOTTING FOR NODC DATA

STANDARD-SIZE ANALYSIS OF SEDIMENTS

TREND-SURFACE WITH UNRESTRICTED I/P

TRANSPORT COMP. FROM ATMOS. PRESSURE

CHLOROPHYLL AND CAROTENOID PIGMENT

PROCESSING OF OCEANOGRAPHIC OBS.

HARMONIC ANALYSIS OF TIDAL DATA

BOTTOM REFLECTIVITY

RAY TRACING

SOUND VELOCITY IN OCEAN WATER

PARAMETRIC MAP

POINT GENERATOR FOR DISTANCE-AZIMUTH

POINT GENERATOR FOR MAP PROJECTIONS

MULTIVARIATE NON-LINEAR REGRESSION

OCEANOGRAPHIC DATA COMPUTATION

SEDIMENT DATA

SEISMIC SLOPING LAYER

ACOUSTIC RAY TRACING

PROJECT COD LIVER

CHLORINITY - SALINITY

CONTINUOUS LINE SOURCE

CONTINUOUS SOURCE PER UNIT DEPTH

CONTINUOUS SOURCE, WITH COOLING TERM

DENSITY - THERMOSTERIC ANOMALY

LATERAL RELATIVE DISTRIBUTION

SURFACE WAVE RAYS

TOTAL CO(2)

MAGNETIC ANOMALIES AND GRADIENTS

SYNOPTIC PROGRAM

SEICHE ANALYSIS

DAILY SEAWATER OBSERVATIONS

CARBONATE-CARBON ANALYSIS OF SED.

CONSOLIDATION TESTS ON OCEAN SEDIMENT

DIRECT SHEAR TEST ON OCEAN SEDIMENT

ENG. INDEX PROP. OF CORE SAMPLES

GRAIN SIZE ANALYSIS - PLOT AND TAB

PERMEABILITY TEST ON OCEAN SED.

SETTLEMENT ANALYSIS

SUMMARY PLOTS OF SED. TEST RESULTS

TRIAXIAL COMPRESSION TEST

DAILY SEAWATER OBSERVATIONS

OCEANS CATALOGUE I AND II

STATISTICS I, II, III

THERMOCHECK - TEMP. CORRECTION

CIRCSTAT

BIOP (BIOLOGY PLOT)

CHLOR

PROFL

S.T.D. DATA PROCESSING

RAY TRACING

SOUND SPEED PROFILES - NORMAL MODES

CHLOROPHYLL AND PRODUCTIVITY

INTERPOLATION PROGRAM

MULTIVARIATE NON-LINEAR REGRESSION

SIMULATION OF TRANSGRESSION IN TIME HARMONIC ANALYSIS OF TIDAL DATA

TIDAL CURRENT PREDICTIION

ECOPROD

JOB (SPECIES DIVERSITY)
CDC 6400 FORTRAN I I 18,90

GE 200 SERFORTRAN I I 14

GE 225 FORTRAN I I 89

GE 225 FORTRAN II 28

GE 225 FORTRAN II 89

GE 225 FORTRAN II 91

GE 225 FORTRAN I I 89

IBM 1620 FORTRAN II 90

IBM 1620 FORTRAN II 55

IBM 1620 FORTRAN II 43

IBM 1620 FORTRAN II 43

IBM 1620 FORTRAN I I 29

IBM 1620 FORTRAN II 47

IBM 1620 FORTRAN I I 67

IBM 1620IIFURTRAN II 05

IBM 1620 I IFORTRAN II 70

IBM 7030 FORTRAN I I 103

IBM 704 FORTRAN II 99

IBM 704 FORTRAN II 99

IBM 704 FORTRAN II 102

IBM 7074 FORTRAN II 64

IBM 7074 FORTRAN I I 64

IBM 7074 FORTRAN I I 63

IBM 709 FORTRAN I I 47

IBM 709 FORTRAN II 90

IBM 709 FORTRAN II 29

IBM 709 FORTRAN II 27

IBM 7090 FORTRAN II 94

IBM 7090 FORTRAN II 50

IBM 7094 FORTRAN II 12

IBM 7094 FORTRAN II 71

IBM 7094 FORTRAN I I 71

IBM 7094 FORTRAN I I 71

IBM 7094 FORTRAN I I 90

IBM 7094 FORTRAN I I 70

IBM 7094 FORTRAN II 105

IBM 7094 FORTRAN I I 12

IBM 7094 FORTRAN I I 26

IBM7094-IIFORTRAN I I 18,90

17040 DCS

IBM 360/5OFORTRAN I I 107

IBM 1620 FORTRAN II-D 79

IBM 1620 IIFORTRAN II-D 29

IBM 1620 IIFURTRAN II-D 30

IBM 1620 IIFORTRAN II-D 30

IBM 1620 I IFORTRAN II-D 29

IBM 1620 I IFORTRAN II-D 29

IBM 1620 IIFORTRAN II-D 30

IBM 1620 IIFORTRAN II-D 31

IBM 1620 I IFORTRAN II-D 31

IBM 1620 IIFORTRAN II-D 30

CDC 3100 FORTRAN IV 79

CDC 3100 FORTRAN IV 113

CDC 3100 FORTRAN IV 56

CDC 3100 FORTRAN IV 17

CDC 3400 FORTRAN IV 52

CDC 3600 FORTRAN IV 33

CDC 3600 FORTRAN IV 08

CDC 3600 FORTRAN IV 38

CDC 3600 FORTRAN IV 17

CDC 3800 FORTRAN IV 96

CDC 3800 FORTRAN IV 100

CDC 6400 FORTRAN IV 05

CDC 6400 FORTRAN IV 90

CDC 6400 FORTRAN IV 47

CDC 6400 FORTRAN IV 54

CDC 6600 FORTRAN IV 103

CDC 6600 FORTRAN IV 104

CDC 6600 FORTRAN IV 05

CDC 6600 FORTRAN IV O6 
OXYGEN

POWER SPECTRUM OF GEOLOGICAL SURFACE TREND ANALYSIS USING FOURIER SERIES OXYGEN COMPUTATION

PHOSPHATE COMPUTATION

SALINITY CONVERSION

THERMOMETER CORRECTION

SEAKEEP ING

ALERT (SATELLITE TIMES)

ASORT (SORT O/P OF ALERT)

ANAL. OF NON-LINEAR RESPONSE SURFACES

HYDRO (COMPUTE FROM HYDRO DATA)

MULDA (MULTIPLE DISCRIMINANT ANAL.)

PLOG (PLOT HYDRO. DATA)

RYLD (FISH STOCK YIELD)

SPECIAL CHEMISTRY CALCULATIONS

S.T.D. CALCULATIONS

TRANSPORT COMP. FROM ATMOS. PRESSURE STPOI (PLOT S.T.D. DATA)

STPO2 (COMPUTE FROM S.T.D. DATA)

TREND-SURFACE WITH UNRESTRICTED I/P

BRAINCON DATA REDUCTION

CABLE CONFIGURATION

CURRENT METER ANALYSIS

CURRENT METER CONVERSION

HILO!'

HNAV (LORAN/DECCA COORDINATES CALC.)

HNVI (LORAN/DECCA FILE)

SBWRO (WAVE RECORDER ANALYSIS)

SDANO (INVERSE GEODETIC)

VAPW (SATURATION VAPOR PRESSURE)

CADS (CALC. DEPENDENT QUANTITIES) GO (POT. TEMP., SIGMA THETA, OXY.)

TWO FIVE (DATA REDUCTION)

TRANSPORT COMP. FROM ATMOS. PRESSURE POWER SPECTRUM OF GEOLOGICAL SURFACE TREND SURFACES DEGREES 1 TO 6

SIMULATION OF MARINE SEDIMENTATION 2-DIMENSIONAL REGRESSION

CROSS-ASSOCIATION OF SEQUENCES

DIGITAL POWER SPECTRUM ANALYSIS

LONG. STRENGTH OF SHIP HULL

PARTIAL AND ORDINARY COHERENCE

SAVED (BLAST TEST DATA REDUCTION)

STATISTICAL AND PEAK-TO-PEAK ANAL.

ASTRONOMICAL TIDE PREDICTION

REFRACTION OF WAVES

SIMULATION OF WIND-GENERATED WAVES

SEA ICE STUDIES

SIMULATION OF MARINE SEDIMENTATION VECTOR TREND ANAL. DIRECTIONAL DATA WAVE FORCE DISTRIBUTION

WAVE FORCES AND MOMENTS

PROFIL (TSUNAMI PROFILES)

OPTIMIZATION OF VTE WATER PLANTS

S.T.D. CORRECTION

TIME TERM, SEISMIC REFRACTION INTERP.

CONDU (THERMAL CONDUCTIVITY)

BKGEOL (SEDIMENT STATISTICS)

CONCENTRATIONS PER SQUARE METER

PHYTOPLANKTON NUMBERS, ETC.

SDGVEL (SOUNDING CORRECTION)

SEDIMENT GRANULOMETRIC ANALYSIS

WAVE STATISTICS
CDC 6600 FORTRAN IV

GE 625 FORTRAN IV

GE 625 FORTRAN IV

$\mathrm{H}-516$ FORTRAN IV

H-516 FORTRAN IV

$\mathrm{H}-516$ FORTRAN IV

H-5 16

IBM 1130

IBM 1130

IBM 1130

FORTRAN IV

FORTRAN IV

FORTRAN IV

FORTRAN IV

FORTRAN IV

FORTRAN IV

FORTRAN IV

FORTRAN IV

FORTRAN IV

FORTRAN IV

FORTRAN IV

FORTRAN IV

FORTRAN IV

FORTRAN IV

FORTRAN IV

FORTRAN IV

FORTRAN IV

FORTRAN IV

FORTRAN IV

FORTRAN IV

FORTRAN IV

FORTRAN IV

FORTRAN IV

FORTRAN IV

FORTRAN IV

FORTRAN IV

FORTRAN IV

FORTRAN IV

FORTRAN IV

FORTRAN IV

FORTRAN IV

$\begin{array}{lll}\text { IBM } 7040 & \text { FORTRAN IV } \\ \text { IBM } 7040 & \text { FORTRAN IV }\end{array}$

$\begin{array}{lll}\text { IBM } 7040 & \text { FORTRAN } & \text { IV } \\ \text { IBM } 7040 & \text { FORTRAN IV }\end{array}$

IBM7040/44FORTRAN IV

IBM 7090 FORTRAN IV

IBM 7090 FORTRAN IV

IBM 7090 FORTRAN IV

IBM 7090 FORTRAN IV

IBM 7090 FORTRAN IV

IBM $7090 / 94$ FORTRAN IV

IBM 7090/94FORTRAN IV

IBM7090/94FORTRAN IV

IBM $7090 / 94 F O R T R A N$ IV

IBM $7090 / 94 F O R T R A N$ IV

IBM7090/94FORTRAN IV

IBM7090/94FORTRAN IV

IBM7090/94FORTRAN IV

IBM 7094 FORTRAN IV

IBM 7094 FORTRAN IV

IBM 7094 FORTRAN IV

IBM 7094 FORTRAN IV

IBM7094-I IFORTRAN IV

17040 DCS

IBM7094-I IFORTRAN IV

17040 DCS

IBM7094-I IFORTRAN IV

17040 DCS

IBM7094-I IFORTRAN IV

17040 DCS

IBM7094-I IFORTRAN IV

17040 DCS

IBM7094-I IFORTRAN IV

17040 DCS

IBM OS/36OFORTRAN IV
06

54

55

11

11

11

16

109

58

58

52

84

53

36

05

09

18

67

37

84

47

15

73

73

73

48

63

63

48

63

66

84

85

17

67

54

47

33

45

54

48

110

49

49

49

104

110

111

75

33

34

109

109

107

12

19

27

31

31

07

07

102

110

PAGE 131 
BLACKY (TIME SERIES ANALYSIS) CURRENT

DETRND, ETC. (SPECTRA SUBROUT+NES)

LENGI (WAVE LENGTH AND SPEED)

PROF ILE

PROF 1 (WATER ELEV. OVER WAVE PERIOD)

REFL I (REFLECTED WAVE)

UMAXI, ETC. (MAX. FLOW VELOC.)

UOFT 1, ETC. (FLOW VELOCITIES)

INVENTORY PLOT

SUBROUTINE 'MAP'

RAYTR (RAY-TRACING)

AOU, ISAOU (CALC. OF OXYGEN, ETC.)

GDNP, GRAD (CALC. OF GRADIENTS)

GVPA, VPA (CALC. OF CURRENTS)

ISOS, OXOS, PHOS (ISENTROPIC PLOT)

LENGTH-WEIGHT FREQUENCY

LONG WAVE RADIATION

OCEANOGRAPHIC REPORT PREPARATION

OCEANOGRAPHIC SUMMARY (NOS. 1,2,3)

REVERSING THERMOMETER CORRECTION

TSIP, THOX, THOT (PLOT TIME HISTORY)

FLOW METER PLOTS

GENERAL MERCATOR PLOT

HORIZONTAL SECTIONS

IN SITU OCEANOGRAPHIC DATA

INTERPOLATION

MERCATOR STATION PLOT

OXYGEN, PHOSPHATE, DENSITY PLOTS

TEMPERATURE-SAL INITY CURVES

OCEANS II I

THERMOCHECK - TEMP. CORRECTION

WATER CHEMISTRY

Q-MODE CLUSTER ANALYSIS

OPTIMUM TRACK SHIP ROUTING

NEWFIT

PATTERN FUNCTION CALCULATIONS

RAY SORT

SONAR IN REFRACTIVE WATER

SPECTRAL ANALYSIS OF TIME SERIES

AZIZ (THERMOMETRIC DEPTH)

CARDS

DELINT

DEPTHS

HEIGHT

HYDRO

INTEST

LINT (LINEAR INTERPOLATION)

RDTHRM (READ THERMOMETER DATA)

SI GMA

SIGMAD

SIGMAT

TEMP

TSPLOT

UTEMP (UNPROTECTED THERMOMETER)

PERCENTAGE SATURATION OF OXYGEN

OBJECTIVE THERMOCLINE ANALYSIS

OBJECTIVE THERMOCLINE ANALYSIS

ASTRONOMIC POSITION

PROFILE CARD-TO-TAPE FOR GEOPAC

TALWANI 2-D GRAVITY

SIMULATION OF DELTAIC SEDIMENTATION ATG IADIABATIC TEMPERATURE GRADIENT BETA-MODEL WITH WHITE FORCING

DATA

DSTABF (STABILITY FREQUENCY)

HISTO (HISTOGRAM PLOT)

HYLOG (HYDRO. STA. DATA REDUCTION)

LISPLO (LIST AND PLOT)
IBM OS/36OFORTRAN IV

IBM OS/36OFORTRAN IV

IBM 360/40FORTRAN IV

IBM $360 / 4$ OFURTRAN IV

IBM 360/40FORTRAN IV

IBM 360/40FURTRAN IV

IBM $360 / 40 F O R T R A N$ IV

IBM $360 / 40 F O R T R A N$ IV

IBM $360 / 4$ OFORTRAN IV

IBM $360 / 40 F O R T R A N$ IV

IBM $360 / 40 F O R T R A N$ IV

IBM $360 / 44 F O R T R A N$ IV

IBM $360 / 65 F O R T R A N$ IV

IBM $360 / 65$ FORTRAN IV

IBM $360 / 65$ FORTRAN IV

IBM $360 / 65 F O R T R A N$ IV

IBM 360/65FORTRAN IV

IBM $360 / 65$ FORTRAN IV

IBM 360/65FORTRAN IV

IBM 360/65FORTRAN IV

IBM 360/65FORTRAN IV

IBM $360 / 65 F O R T R A N$ IV

IBM $360 / 65 F O R T R A N$ IV

IBM 360/65FORTRAN IV

IBM $360 / 65 F O R T R A N$ IV

IBM $360 / 65 F O R T R A N$ IV

IBM 360/65FORTRAN IV

IBM 360/65FORTRAN IV

IBM $360 / 65 F O R T R A N$ IV

IBM 360/65FORTRAN IV

IBM 360/65FORTRAN IV

IBM $360 / 65 F O R T R A N$ IV

IBM 360/65FORTRAN IV

IBM360/67, FORTRAN IV

IBM7090/94

UNIVACIIOTFORTRAN IV

UNIVACIIOBFORTRAN IV

UN IVACIIOBFORTRAN IV

UNIVACIIO8FORTRAN IV

UNIVACIIOBFORTRAN IV

UNIVACI 108 FORTRAN IV

IBM 360/5OFORTRAN IV-E

IBM 360/5OFORTRAN IV-E

IBM $360 / 5$ OFURTRAN IV-E

IBM $360 / 5$ OFORTRAN IV-E

IBM 360/5OFORTRAN IV-E

IBM $360 / 5$ OFORTRAN IV-E

IBM $360 / 5$ OFORTRAN IV-E

IBM 360/5OFORTRAN IV-E

IBM $360 / 50 F O R T R A N$ IV $-E$

IBM 360/5OFORTRAN IV-E

IBM $360 / 50 F O R T R A N$ IV-E

IBM $360 / 5$ OFORTRAN IV-E

IBM $360 / 5$ OFORTRAN IV-E

IBM $360 / 5$ OFORTRAN IV-E

IBM $360 / 5$ OFORTRAN IV-E

IBM $360 / 65 F O R T R A N$ I $V-G$

CDC 6500 FORTRAN IV-H

IBM OS/36OFORTRAN IV $\mathrm{VH}$

IBM 360/65FORTRAN IV-H

IBM 360/65FORTRAN IV-H

IBM 360/65FORTRAN IV $-\mathrm{H}$

IBM $360 / 67 F O R T R A N$ IV-H

SDS SIGMATFORTRAN I $V-H$

SDS SIGMATFORTRAN IV-H

SDS SIGMATFURTRAN IV-H

SDS SIGMATFORTRAN I $V-H$

SDS SIGMATFORTRAN I $V-H$

SDS SIGMATFORTRAN I $V-H$

SDS SIGMATFORTRAN IV-H
49

56

48

107

108

108

108

109

108

41

63

97

10

76

69

40

06

25

91

79

20

41

72

40

40

85

86

40

39

39

86

17

09

55

106

95

95

95

94

50

88

22

88

22

87

19

88

88

22

89

89

87

19

44

19

10

75

75

59

26

26

34

92

52

22

92

43

20

44 
NUSPEC (SPECTRUM ESTIMATION)

OCCOMP (OCEANOGRAPHIC COMPUTE)

POTEMP (POTENTIAL TEMPERATURE)

PRESS

PROVEC (PROGRESSIVE VECTORS)

SCRUB (DATA EDIT AND CORRECT)

SI GMAT

SONVEL (SOUND VELOCITY)

SPVOL

STATS (STATISTICAL QUANTITIES)

SVANOM (SPECIFIC VOLUME ANOMALY)

THISTO (TWO-DIMEN. FREQ. DISTRIB.)

THRCL (THERMOMETER CALIBRATION)

VECTAV (VECTOR AVERAGES)

VEL (GEOSTROPHIC VELOCITY)

VTR (VOLUME TRANSPORT)

Q FACTORS

RAYMOR

PSAL1 (PLOT TEMPERATURE-SALINITY)

TCHK 3 (THERMOMETER CORR •)

TIME SERIES PLOTTING

FILM DATA PROCESSING

ICEGRID MODIFIED

TIDES

SEA SURFACE TEMP. AND ANOMALY SUM.

SEA SURFACE TEMP. DATA SUMMARY

SYNOPTIC MARINE WEATHER DATA SUMMARY VACOTS (VERTICAL SECTION PLOT)

ACOUSTIC RAY TRACING

DATUBA (BUOY-CABLE DEFLECT •)

GENERAL VELOCITY FIELD

HORIZONTAL GRADIENT RAY TRACING

RAY TRACE PROCESSING

TWO FIVE (DATA REDUCTION)

ASTRONOMICAL TIDE PREDICTION
SDS SIGMA7FORTRAN I $\mathrm{V}-\mathrm{H}$

SDS SIGMATFORTRAN IV-H

SDS SIGMATFORTRAN I $V-H$

SDS SIGMATFORTRAN I $V-H$

SDS SIGMATFORTRAN IV-H

SDS SIGMATFORTRAN I V-H

SDS SIGMATFURTRAN I $V-H$

SDS SIGMA7FORTRAN IV-H IO

SDS SIGMATFORTRAN IV-H 92

SDS SIGMATFORTRAN IV-H 57

SDS SIGMA TFURTRAN IV-H 92

SDS SIGMATFORTRAN IV-H 74

SDS SIGMATFORTRAN IV-H 20

SDS SIGMA7FORTRAN IV-H 74

SDS SIGMATFORTRAN IV-H 73

SDS SIGMATFORTRAN IV-H 73

ATLAS I FORTRAN V 15

UNIVACIIOBFORTRAN V 95

IBM 1130 FORTRAN VI 37

IBM 1130 FORTRAN VI 16

CDC 3100 FORTRAN-32 36

CDC 1604 FURTRAN-60 72

CDC 1604 FORTRAN-60 74

NOT GIVEN FURTRAN-60 105

CDC 3600 FORTRAN-62 81

CDC 3600 FORTRAN-62 81

CDC 3600 FURTRAN-62 80

CDC 3600 FORTRAN-63 39

CDC 3800 FURTRAN-63 96

CDC 3800 FORTRAN-63 72

CDC 3800 FORTRAN-63 101

CDC 3800 FORTRAN-63 96

CDC 3800 FORTRAN-63 96

CDC 3600 FORTRAN-63 17

CDC 6600 FORTRAN-66 104

MAC

CURRENT METER DYNAMICS

CHLOROPHYLL CALCULATIONS

DELTA-ALPHA AND SIGMA-T

HARMONIC ANALYSIS

TIDAL PREDICTION

VELOCITY OF SOUND
IBM OS/36OMAC

ICT 1301 MAC

ICT 1301 MAC

ICT 1301 MAC

ICT 1301 MAC

ICT 1301 MAC
72

07

93

51

105

103

MAD

AVG. TEMPERATURES IN WATER COLUMN DYNAMIC HEIGHT AND CURRENT DYNAMICS GENERAL MAP PROJECTION MAP PROJECTION DISTORTIONS THEORETICAL RADIAL TIDAL FORCE TREND MAP, WITH RESIDUALS WIND CURRENTS
IBM 7090 MAD

IBM 7090 MAD

IBM 7090 MAD

IBM 7090 MAD

IBM 7090 MAD

IBM 7090 MAD

IBM 7090 MAD
81

93

65

65

104

47

68

PAL

DISSOLVED OXYGEN, POTENTIAL TEMP. OCEAN STATION ANALYSIS AND SUMMARY THERMOMETER CORR. AND THERMO. DEPTH DATA REDUCTION FOR THE PDP-8
PDP-5, 8S PAL I I I

93

PDP-5, 8S PAL III

PDP-5, 85 PAL III

PDP-8 PAL III
93

20

14

SCRAP WAVES

SCRAP

82

SCRAP

106 
SP 5

OCEANS II REPORT GENERATOR BATHYTHERMOGRAPH OUTPUT CONVERSION, NODC TO ICES OCEAN STATION DATA OUTPUT, NODC OCEAN STATION DEPTH SUMMARY STA. DATA CONVERSION, CODC TO NODC COMPUTE GEOGRAPHIC POSITIONS LORAN C

IBM 1401 SPS

IBM 1401 SPS

IBM 1401 SPS

IBM 1401 SPS

IBM 1401 SPS

IBM 1401 SPS

IBM 1620 SPS

IBM 1620 SPS
23

23

23

15

24

61

62

MISCELLANEOUS

\author{
S.T.D. CALCULATIONS \\ SATELLITE NAVIGATION \\ GENERAL REGRESSION \\ POWER SPECTRUM ANALYSIS \\ THERMOMETER CORRECTIONS \\ TIDAL ANALYSIS AND PREDICTION \\ BOMM (TIME SERIES) \\ LINE PRINTER PLOTS \\ BIOLOGICAL STATION FILE \\ STATION DATA (ATLAS) \\ AN/UYK-I SOUND VELOCITY
}

$\begin{array}{llr}\text { IBM } 1130 & \text { ASSEMBLER } & 18 \\ \text { IBM } 1801 & \text { ASSEMBLER } & 58 \\ \text { IBM } 360 / 65 \text { PL/1 } & 45 \\ \text { PB-250 } & \text { BASIC } & 51 \\ \text { MERCURY } & \text { CHLF } 3 / 4 & 15 \\ \text { MERCURY } & \text { CHLF } 3 / 4 & 104 \\ \text { CDC 3600 } & \text { COMPASS } & 52 \\ \text { CDC 3800 } & \text { COMPASS } & 35 \\ \text { ATLAS I } & \text { EMA } & 112 \\ \text { ATLAS 1 } & \text { EMA } & 83 \\ \text { AN/UYK-1 } & \text { LOGANDS } & 103\end{array}$


BURROUGHS

2-DIMENSIONAL REGRESSION

SPECTRAL ANALYSIS OF TIME SERIES

B5500

B5500

ALGOL

ALGOL 60

CONTROL DATA CORPORATION

FATHOMETER CORRECTION

MACHINE PLOTTING ON MERCATOR PROJ.

VC2AP3 SHIP ROUTING

FILM DATA PROCESSING

ICEGRID MODIFIED

DATA FIELD GRID EXPANSION

FORECASTING OF SURFACE CURRENTS

GG T SEA

POTENTIAL MIXED LAYER DEPTH

SEA SURFACE TEMPERATURE ANALYSIS

SUBSURFACE THERMAL STRUCTURE ANALYSIS

TWO DIMENSIONAL RAY TRACE

WAVES

NUTRIENT CHEMISTRY CONCENTRATION

OCEAN STATION COMPUTATIONS

PRIMARY PRODUCTIVITY

RADIATION ATTENUATION

ZOOPLANKTON VOLUME

DATA REDUCTION FOR THE CDC 3100

ISALBP (SALINITY ANOMALY)

ISATBP (OXYGEN ANOMALY AND SAT.)

LEAST SQUARES CURVE FITTING

PLOT STATION POSITIONS

PLOT THETA-S CURVES

SECTION PLOTTING

TEMPERATURE-SALINITY PLOT

SODANO INVERSE

SOUNDING PLOT

SVLIM (SOUND VELOCITY RETRIEVAL)

DAILY SEAWATER OBSERVATIONS

OCEANS CATALOGUE I AND I I

STATISTICS I, II, III

THERMOCHECK - TEMP. CORRECTION

TIME SERIES PLOTTING

DATA FIELD GRID EXPANSION

BECNAV (BEACON NAVIGATION)

SPANSIA (BEACON POSITION)

SPANSIB (BEACON POSITION)

INTERPOLATION FOR OCEANOGRAPHIC DATA

POWER SPECTRA ESTIMATION

SOUND VELOCITY

FORECASTING OF SURFACE CURRENTS

POTENTIAL MIXED LAYER DEPTH

TWO DIMENSIONAL RAY TRACE

HYDROGRAPHIC DATA PROGRAM

RADIONUCLIDE SPECTRUM ANALYSIS (2)

TEMPERATURE CORRECTIONS

CIRCSTAT

BOMM (TIME SERIES)

PROGRAM REGROUP

BIOP (BIOLOGY PLOT)

CHLOR

PROFL

S.T.D. DATA PROCESSING

SEA SURFACE TEMP. AND ANOMALY SUM.

SEA SURFACE TEMP. DATA SUMMARY

SYNOPTIC MARINE WEATHER DATA SUMMARY

VACOTS (VERTICAL SECTION PLOT)
CDC 1604

CDC 1604

$\operatorname{COC} 1604$

CDC 1604

CDC 1604

CDC 1604

CDC 1604

CDC 1604

CDC 1604

CDC 1604

CDC 1604

CDC 1604

CDC 1604

CDC 1604

CDC 1604

CDC 1604

CDC 1604

CDC 1604

CDC 3100

CDC 3100

CDC 3100

CDC 3100

CDC 3100

$\operatorname{CDC} 3100$

$\operatorname{CDC} 3100$

CDC 3100

CDC 3100

CDC 3100

CDC 3100

$\operatorname{CDC} 3100$

CDC 3100

CDC 3100

$\operatorname{CDC} 3100$

$\operatorname{CDC} 3100$

$\operatorname{CDC} 3100$

CDC 3200

CDC 3200

CDC 3200

CDC 3200

CDC 3200

CDC 3200

CDC 3200

CDC 3200

CDC 3200

$\operatorname{CDC} 3300$

CDC 3300

CDC 3300

CDC 3400

CDC 3600

CDC 3600

CDC 3600

CDC 3600

CDC 3600

CDC 3600

CDC 3600

CDC 3600

CDC 3600

CDC 3600
FORTRAN 101

FORTRAN 39

FURTRAN 106

FORTRAN-60 72

FURTRAN-60 $\quad 74$

MACHINE $\quad 44$

MACHINE 67

MACHINE 81

MACHINE 68

MACHINE 81

SCRAP 82

SCRAP, MAP 99

SCRAP $\quad 106$

(NOT GIVEN) 08

(NOT GIVEN) 93

(NOT GIVEN) 08

(NOT GIVEN) 94

(NOT GIVEN) 08

FORTRAN II 14,83

FORTRAN II 10

FURTRAN II 10

FORTRAN II 45

FORTRAN II 36

FORTRAN I I 35

FORTRAN 36

FORTRAN 39

FORTRAN 60

FORTRAN $\quad 35$

FORTRAN I I 101

FORTRAN IV 79

FORTRAN IV 113

FURTRAN IV 56

FORTRAN IV 17

FORTRAN-32 36

MACHINE $\quad 44$

FORTRAN 58

FORTRAN 58

FORTRAN 59

FORTRAN 83

FORTRAN 51

FORTRAN 100

MACHINE $\quad 48$

MACHINE 68

SCRAP, MAP 99

FORTRAN 56

FORTRAN 10

FORTRAN $1 I$

FORTRAN IV 52

COMPASS 52

FORTRAN 07

FORTRAN IV 33

FORTRAN IV 08

FORTRAN IV 38

FORTRAN IV 17

FORTRAN-62 81

FORTRAN-62 81

FORTRAN-62 80

FORTRAN-63 39 
TWO FIVE (DATA REDUCTION)

BLACKBODY RADIANCE

BLACKBODY SPECTRAL RADIANCE

DETERMINANT OF A SYMMETRIC MATRIX

DISTANCE BETWEEN TWO POINTS

EVALUATE BESSEL FUNCTIONS

FIND REAL ZEROS OF FUNCTION

GREAT CIRCLE PATHS FROM A POINT

GREAT CIRCLE RETRIEVAL

LINE PRINTER PLOTS

NELED I T

PROPAGATION LOSS - NORMAL MODES

SCAL ING SUBROUTINE

THREE-DIMENSIONAL SURFACE PLOTS

UTILITY

RAY TRACING

SOUND SPEED PROFILES - NORMAL MODES

ACOUSTIC RAY TRACING

DATUDA (BUOY-CABLE DEFLECT •)

GENERAL VELOCITY FIELD

HORIZONTAL GRADIENT RAY TRACING

RAY TRACE PROCESSING

WAVEIN AND DIFRAK

OCEANOGRAPHIC DATA COMPUTATION

SEDIMENT DATA

SYNOPTIC PROGRAM

CHLOROPHYLL AND PRODUCTIVITY

INTERPOLATION PROGRAM

MULTIVARIATE NON-LINEAR REGRESSION

SIMULATION OF TRANSGRESSION IN TIME

OBJECTIVE THERMOCLINE ANALYSIS

TRLOSS (TRANSMISSION LOSS)

HARMONIC ANALYSIS OF TIDAL DATA

TIDAL CURRENT PREDICTION

ECOPROD

JOB (SPECIES DIVERSITY)

OXYGEN

ASTRONOMICAL TIDE PREDICTION

$\begin{array}{lllr}\text { CDC } 3600 & \text { FURTRAN-63 } & 17 \\ \text { CDC } 3800 & \text { FORTRAN } & 25 \\ \text { CDC } 3800 & \text { FURTRAN } & 25 \\ \text { CDC } 3800 & \text { FORTRAN } & 53 \\ \text { CDC } 3800 & \text { FURTRAN } & ; 9 \\ \text { CDC } 3800 & \text { FURTRAN } & 53 \\ \text { CDC } 3800 & \text { FURTRAN } & 53 \\ \text { CDC } 3800 & \text { FORTRAN } & 59 \\ \text { CDC } 3800 & \text { FURTRAN } & 11 \\ \text { CDC } 3800 & \text { FORTRAN } & 35 \\ & & \text { COMPASS } & \\ \text { CDC } 3800 & \text { FORTRAN } & 21 \\ \text { CDC } 3800 & \text { FORTRAN } & 100 \\ \text { CDC } 3800 & \text { FORTRAN } & 53 \\ \text { CDC } 3800 & \text { FORTRAN } & 35 \\ \text { CDC } 3800 & \text { FURTRAN } & 21 \\ \text { CDC } 3800 & \text { FORTRAN IV } & 96 \\ \text { CDC } 3800 & \text { FORTRAN IV } & 100 \\ \text { CDC } 3800 & \text { FURTRAN-63 } & 96 \\ \text { CDC } 3800 & \text { FORTRAN-63 } & 72 \\ \text { CDC } 3800 & \text { FURTRAN-63 } & 101 \\ \text { CDC } 3800 & \text { FORTRAN-63 } & 96 \\ \text { CDC } 3800 & \text { FURTRAN-63 } & 96 \\ \text { CDC } 6400 & \text { FORTRAN } & 50,110 \\ \text { CDC } 6400 & \text { FORTRAN II } & 90 \\ \text { CDC } 6400 & \text { FORTRAN II } & 29 \\ \text { CDC } 6400 & \text { FORTRAN II } & 18,90 \\ \text { CDC } 6400 & \text { FORTRAN IV } & 05 \\ \text { CDC } 6400 & \text { FORTRAN IV } & 90 \\ \text { CDC } 6400 & \text { FURTRAN IV } & 47 \\ \text { CDC } 6400 & \text { FORTRAN IV } & 54 \\ \text { CDC } 6500 & \text { FURTRAN IV-H } & 75 \\ \text { CDC } 6600 & \text { FORTRAN } & 94 \\ \text { CDC } 6600 & \text { FORTRAN IV } & 103 \\ \text { CDC } 6600 & \text { FORTRAN IV } & 104 \\ \text { CDC } 6600 & \text { FORTRAN IV } & 05 \\ \text { CDC } 6600 & \text { FORTRAN IV } & 06 \\ \text { CDC } 6600 & \text { FORTRAN IV } & 06 \\ \text { CDC } 6600 & \text { FORTRAN-66 } & 104 \\ & & & \end{array}$

DIGITAL EQUIPMENT CORPORATION

\author{
DECCA HI-FIX \\ INDUCTIVE SALINOMETER SALINITY CONV. \\ DISSOLVED OXYGEN, POTENTIAL TEMP. \\ OCEAN STATION ANALYSIS AND SUMMARY \\ THERMOMETER CORR. AND THERMO. DEPTH \\ RICHARDSON CURRENT METER FILM READ. \\ THE VORTEX OCEAN MODEL \\ WORLD OCEANO. DATA DISPLAY \\ NEAR-FIELD ARRAY TESTING \\ DATA REDUCTION FOR THE PDP-8
}

$\begin{array}{lll}\text { PDP-5, 8S FORTRAN } & 64 \\ \text { PDP-5, 8S FURTRAN } & 11 \\ \text { PDP-5, 8S PAL I I I } & 93 \\ \text { PDP-5, 8S PAL III } & 93 \\ \text { PDP-5, 8S PAL III } & 20 \\ \text { PDP-7(9) } & \text { DECAL } & 15 \\ \text { PDP-7(9) } & \text { DECAL } & 38 \\ \text { PDP-7(9) } & \text { DECAL } & 38 \\ \text { PDP-8 } & \text { FURTRAN } & 99 \\ \text { PDP-8 } & \text { PAL I I } & 14\end{array}$

GENERAL ELECTRIC

$\begin{array}{lllrl}\text { STADAT } 2 & \text { GE } 200 & \text { SERFORTRAN II } & 14 \\ \text { CRVFT (LEAST SQUARES FIT) } & \text { GE } 225 & \text { FORTRAN } & 46 \\ \text { ORD } 1 \text { (OLMSTED RAY DIAGRAM NO. 1) } & \text { GE } 225 & \text { FORTRAN } & 97 \\ \text { ORD } 2 \text { (OLMSTED RAY DIAGRAM NO. 2) } & \text { GE } 225 & \text { FURTRAN } & 97 \\ \text { DYNHT (OYNAMIC HEIGHTS) } & \text { GE } 225 & \text { FURTRAN II } & 89 \\ \text { GRAIN SIZE } & \text { GE } 225 & \text { FORTRAN II } & 28 \\ \text { PEN (POTENTIAL ENERGY ANOMALY) } & \text { GE } 225 & \text { FURTRAN II } & 89 \\ \text { POTEMP (POTENTIAL TEMPERATURE) } & \text { GE } 225 & \text { FURTRAN II } & 91 \\ \text { VFREO (VAISALA FREQUENCY COMP.) } & \text { GE } 225 & \text { FURTRAN II } & 89 \\ \text { POWER SPECTRUM OF GEOLOGICAL SURFACE GE } 625 & \text { FORTRAN IV } & 54 \\ \text { TREND ANALYSIS USING FOURIER SERIES } & \text { GE } 625 & \text { FURTRAN IV } & 55\end{array}$


HONEYWELL

OXYGEN COMPUTATION

PHOSPHATE COMPUTATION

SALINITY CONVERSION

THERMOMETER CORRECTION
$H-516$

$\mathrm{H}-516$

$\mathrm{H}-516$

$\mathrm{H}-516$
FORTRAN IV

FORTRAN IV

FORTRAN IV

FORTRAN IV
11

11

11

I BM

REDUCTION, DISPLAY OF SEA DATA

S.T.D. CALCULATIONS

DEAD RECKONING NAVIGATION SYSTEM

S.T.D. EDIT AND INTERPOLATE

UNDERWAY DATA SYSTEM

SEAKEEPING

ALERT (SATELLITE TIMES)

ASORT (SORT O/P OF ALERT)

ANAL. OF NON-LINEAR RESPONSE SURFACESIBM

HYDRO (COMPUTE FROM HYDRO DATA)

MULDA (MULTIPLE DISCRIMINANT ANAL.)

PLOG (PLOT HYDRO. DATA)

RYLD (FISH STOCK YIELD)

STPO1 (PLOT S.T.D. DATA)

STPO2 (COMPUTE FROM S.T.D. DATA)

SPECIAL CHEMISTRY CALCULATIONS

S.T.D. CALCULATIONS

TRANSPORT COMP. FROM ATMOS. PRESSURE

PSALI (PLOT TEMPERATURE-SALINITY)

TCHK3 (THERMOMETER CORR .)

JOB EDIT FOR L-Z PROGRAM

OCEAN STA. CURVE PLOTTING FOR 1401

TEMPERATURE AND DEPTH CALCULATIONS COMPUTE ADVECTION

TWO-DIMENSIONAL AUTOCORRELATION

OCEANS I I REPORT GENERATOR

BATHYTHERMOGRAPH OUTPUT

CONVERSION, NODC TO ICES

OCEAN STATION DATA OUTPUT, NODC

OCEAN STATION DEPTH SUMMARY

STA. DATA CONVERSION, CODC TO NODC

ALKALINITY AND SPECIFIC ALKALINITY

INTERPOLATION FOR OCEANOGRAPHIC DATA SALINITY VALUE CALCULATION

TEMPERATURE AND DEPTH CALCULATIONS

THERMOCHECK II - TEMP. CORRECTION

VELOCITY OF SOUND

TRANSPORT COMP. FROM ATMOS. PRESSURE

DYNAMIC HEIGHT CALCULATION

MULTIVARIATE DISCRIMINANT ANALYSIS

OCEANO. DATA PLOTTING FOR ICES DATA

OCEANO. DATA PLOTTING FOR NODC DATA

STANDARD-SIZE ANALYSIS OF SEDIMENTS

TREND-SURFACE WITH UNRESTRICTED I/P

DAILY SEAWATER OBSERVATIONS

COMPUTE GEOGRAPHIC POSITIONS

LORAN C

CHLOROPHYLL AND CAROTENOID PIGMENT

PROCESSING OF OCEANOGRAPHIC OBS.

CARBONATE-CARBON ANALYSIS OF SED.

CONSOLIDATION TESTS ON OCEAN SEDIMENT

DIRECT SHEAR TEST ON OCEAN SEDIMENT

ENG. INDEX PROP. OF CORE SAMPLES

GRAIN SIZE ANALYSIS - PLOT AND TAB

PERMEABILITY TEST ON OCEAN SED.

SETTLEMENT ANALYSIS

SUMMARY PLOTS OF SED. TEST RESULTS

TRIAXIAL COMPRESSION TEST

ALPHA (SPECIFIC VOLUME)

\begin{tabular}{|c|c|c|c|c|}
\hline I BM & 1130 & FORTRAN & \multicolumn{2}{|c|}{$14,25,60$} \\
\hline I BM & 1130 & ASSEMBLE & $R$ & \\
\hline I BM & 1130 & FORTRAN & & \\
\hline I BM & 1130 & FORTRAN & & \\
\hline I BM & 1130 & FORTRAN & & \\
\hline & 1130 & FORTRAN & IV & \\
\hline & 1130 & FURTRAN & I V & \\
\hline & 1130 & FURTRAN & I V & \\
\hline $3 M$ & 1130 & FORTRAN & IV & \\
\hline & 1130 & FURTRAN & IV & \\
\hline & 1130 & FORTRAN & IV & \\
\hline & 1130 & FORTRAN & IV & \\
\hline & 1130 & FORTRAN & IV & \\
\hline & 1130 & FORTRAN & I V & \\
\hline & 1130 & FORTRAN & I V & \\
\hline M & 1130 & FORTRAN & IV & \\
\hline BM & 1130 & FORTRAN & IV & \\
\hline & 1130 & FURTRAN & IV & \\
\hline$B M$ & 1130 & FURTRAN & VI & \\
\hline M & 1130 & FORTRAN & V I & \\
\hline M & 1401 & AUTOCODE & & \\
\hline I BM & 1401 & AUTOCODE & & \\
\hline I BM & 1401 & AUTOCODE & & \\
\hline I $B M$ & 1401 & FORTRAN & & \\
\hline $3 M$ & 1401 & FORTRAN & & \\
\hline I BM & 1401 & SPS & & \\
\hline I BM & 1401 & SPS & & \\
\hline$B M$ & 1401 & SPS & & \\
\hline$B M$ & 1401 & SPS & & \\
\hline$B M$ & 1401 & SPS & & \\
\hline$B M$ & 1401 & SPS & & \\
\hline$B M$ & 1620 & FURTRAN & & \\
\hline I BM & 1620 & FORTRAN & & \\
\hline I BM & 1620 & FORTRAN & & \\
\hline I BM & 1620 & FORTRAN & & \\
\hline I BM & 1620 & FORTRAN & & \\
\hline$B M$ & 1620 & FORTRAN & & \\
\hline BM & 1620 & FORTRAN & I I & \\
\hline I BM & 1620 & FORTRAN & I I & \\
\hline I BM & 1620 & FORTRAN & I I & \\
\hline I BM & 1620 & FORTRAN & I 1 & \\
\hline$B M$ & 1620 & FORTRAN & I I & \\
\hline I BM & 1620 & FORTRAN & I I & \\
\hline I BM & 1620 & FORTRAN & I I, & \\
\hline & & I V, BALG & $\mathrm{OOL}$ & \\
\hline I BM & 1620 & FORTRAN & I I -D & \\
\hline$B M$ & 1620 & SPS & & \\
\hline I BM & 1620 & SPS & & \\
\hline I BM & 16201 & IFURTRAN & I I & \\
\hline I BM & $1620 \mathrm{I}$ & IFURTRAN & I I & \\
\hline I BM & $1620 \mathrm{I}$ & I FORTRAN & I I -D & \\
\hline I BM & 16201 & IFORTRAN & I I -D & \\
\hline$I B M$ & 16201 & IFORTRAN & I I $-D$ & \\
\hline I BM & $1620 \mathrm{I}$ & IFORTRAN & I I-D & \\
\hline I BM & $1620 \mathrm{I}$ & I FORTRAN & I I -D & \\
\hline & & IFURTRAN & II $-D$ & \\
\hline I BM & 16201 & IFORTRAN & I I -D & \\
\hline I BM & $1620 \mathrm{I}$ & IFORTRAN & I $I-D$ & \\
\hline I BM & $1620 \mathrm{I}$ & IFORTRAN & I I -D & \\
\hline I BM & 1800 & FORTRAN & & \\
\hline
\end{tabular}


BARTLETT IS CURVE FITTING

CLUSTER ANALYSIS

POTLT (POTENTIAL TEMPERATURE)

SATELLITE NAVIGATION

SDVEL

SIGMO

SIGMT

2D MAGNETIC ANOMALIES

BRAINCON DATA REDUCTION

CABLE CONFIGURATION

CURRENT METER ANALYSIS

CURRENT METER CONVERSION

HILOW

HNAV (LORAN/DECCA COORDINATES CALC.) HNV I (LORAN/DECCA FILE)

SBWRO (WAVE RECORDER ANALYSIS)

SDANO (INVERSE GEODETIC)

VAPW (SATURATION VAPOR PRESSURE)

CADS (CALC. DEPENDENT QUANTITIES)

GO (POT. TEMP., SIGMA THETA, OXY.)

TWO FIVE (DATA REDUCTION)

HARMONIC ANALYSIS OF TIDAL DATA

POWER SPECTRUM ANALYSIS

BOTTOM REFLECTIVITY

RAY TRACING

SOUND VELOCITY IN OCEAN WATER

WAVE SHOALING

POWER SPECTRUM OF GEOLOGICAL SURFACE

SIMULATION OF MARINE SEDIMENTATION

TREND SURFACES DEGREES 1 TO 6

2-DIMENSIONAL REGRESSION

TRANSPORT COMP. FROM ATMOS. PRESSURE

CROSS-ASSOCIATION OF SEQUENCES

BATHYTHERMOGRAPH DATA CONVERTER

BIODETER IORATION

DRIFT BOTTLE DATA COMPUTATION

MODIFIED SURFACE CURRENTS

BT ANALYSIS (S.E.R.C. DATA)

STATION DATA COMPUTE

STATION DATA VERTICAL ARRAY SUMMARY

STATISTICAL SURFACE CURRENT ROSE

SURFACE CURRENT SUMMARY

TAPE INPUT AND OUTPUT SUBROUTINE

THERMOCLINE AND MIXED LAYER DEPTHS

THERMOCLINE ONE-DEGREE

AIR-SEA

BATHYMETRIC DATA REDUCTION

BATHYTHERMOGRAM COMPOSITE PLOT

BOTTOM REFLECTION ANALYSIS

BOTTOM SEDIMENT DISTRIBUTION PLOT

BT TEMPERATURE GRADIENT DISTRIBUTION

CIRAZD (DISTANCE-AZIMUTH CALC.)

CIRCULAR CHARTING

$\begin{array}{lr}\text { CIRCULAR CHARTING } & \text { IBM } 7074 \\ \text { CLOUD COVER AND DAILY SEA TEMPERATUREIBM } 7074\end{array}$

CONVERGENCE ZONE RANGE

CRITICAL ACOUSTIC RATIO

CRUISE TRACK

CURRENT METER TURBULENCE

DENSITY GRADIENT BY I-DEGREE SQUARE

DENSITY-SALINITY LINEAR INTERPOL.

DENSITY-SALINITY MID PLOT

ERROR IN VERTICAL SOUND VELOCITY

FAA PLOT

GENERAL PURPOSE PLOT

GEODETIC DATUM CONVERSION

GEODETIC DATUM REDUCTION

GEODETIC POSITION COMP. AND PLOT
IBM 1800

IBM 1800

IBM 1800

I BM 1800

IBM 1800

IBM 1800

IBM 1800

IBM 1800

IBM 1800

IBM 1800

IBM 1800

IBM 1800

IBM 1800

BM 1800

BM 18

IBM 1800

I BM 1800

IBM 1800

I BM 1800

IBM 1800

IBM 7030

IBM 704

IBM 704

IBM 704

IBM 704

IBM 7040

IBM 7040

IBM 7040

IBM 7040

IBM 7040

IBM 7040

IBM70 40/44F

IBM 7074

IBM 7074

IBM 7074

IBM 7074

IBM 7074

IBM 7074

IBM 7074

IBM 7074

IBM 7074

I BM 7074

IBM 7074

IBM 7074

I BM 7074

IBM 7074

IBM 7074

IBM 7074

IBM 7074

IBM 7074

IBM 7074

IBM 7074

IBM 7074

IBM 7074

IBM 7074

IBM 7074

IBM 7074

IBM 7074

IBM 7074

IBM 7074

IBM 7074

IBM 7074

IBM 7074

IBM 7074
URTRAN

FORTRAN

FORTRAN

FORTRAN AND

ASSEMBLER

FORTRAN

FORTRAN

FORTRAN

FORTRAN

FORTRAN IV

FURTRAN IV

FORTRAN IV

FORTRAN IV

FURTRAN IV

FURTRAN IV

FURTRAN IV

FORTRAN IV

FURTRAN IV

FURTRAN IV

FORTRAN IV

FORTRAN IV

FORTRAN IV

FURTRAN II

FORTRAN

FURTRAN II

FORTRAN I I

FORTRAN II

FORTRAN

FORTRAN IV

FORTRAN IV

FORTRAN IV

FURTRAN IV

FORTRAN IV

4FORTRAN IV

AUTOCODER

AUTOCODER

AUTOCODER

AUTOCODER

AUTOCODER

AUTOCODER

AUTOCODER

AUTOCODER

AUTOCODER

AUTOCODER

AUTOCODER

AUTOCODER

AUTOCODER

AUTOCODER

FORTRAN

FURTRAN

FORTRAN

FORTRAN

FORTRAN

FURTRAN

FURTRAN

FURTRAN

FURTRAN

FORTRAN

FORTRAN

FORTRAN

FORTRAN

FORTRAN

FORTRAN

FORTRAN

FORTRAN

FORTRAN

FORTRAN

FURTRAN

FORTRAN

FORTRAN 
GEOLOGICAL SAMPLE CONVERSION

GEOLOGICAL SAMPLING INVENTORY PLOT

GULF STREAM PATH

ICE POTENTIAL

INTERPOLATION OF OCEAN STATION DATA

INTERPOLATION SPECIFIC VOL ANOMALY

LAYER DEPTH PLOT

LEAST SQUARES PLOT

LIGHT AND SOUND INSTRUCTION B

LIGHT AND SOUND INSTRUCTION D

LORAN A AND C SKYWAVE

LORAN - COORDINATE COMPUTATION

LORAN EDIT

LORAN TO GEOGRAPHIC CONVERSION

MARINE BIOLOG. ENVIRON. SUMMARIES

MARSDEN SQ. AVERAGES FROM GEOFILE

MASS PHYSICAL PROPERTIES

MONTHLY SONIC LAYER DEPTH

OBSERVATION DRAPING (GRAVITY)

OXYGEN SATURATION

PREDICTION OF VERTICAL TEMP. CHANGE

RAY PATH

SALINITY - CONDUCTIVITY FORMULA

SALINITY DEVIATION PROGPLOT

SALINITY GRADIENT BY 1-DEGREE SQUARE

SEA SURFACE TEMPERATURE DISTRIBUTION

SEA SENSE - DATA DISPLAY

SEA SENSE - LIMIT

SEA SENSE - STANDARD DEVIATION

SEAMOUNT MAGNETIZATION

SEDIMENT SIZE

SHIPBOARD SURVEY -- ON-STATION MODE

SHIPBOARD SURVEY -- ON-STATION PLOT

SIGMA-T VS DEPTH, SALINITY (PLOT)

SINGLE INTEGRATION

SOLAR RADIATION CONVERSION

SOUND SPEED EDIT

SOUND VELOCITY DEPTH PROFILES

SOUNDING PLOT

STANDARD-VECTOR DEVIATION ROSE

STATION DATA PARAMETER INVENTORY

STATION DATA PLOT - SIX VARIABLES

STATISTICAL ANALYSIS OF ICE DATA

TEMPERATURE AVG SUMMARY BY 1-DEG SO IBM 7074

TEMPERATURE DISTRIBUTION BY 1-DEG SQ. IBM 7074

THERMOM. CORR •, THERMO. DEPTH

2-DIMENSION POWER SPECTRUM (SWOP II) IBM 7074

VAM INTERPOLATION II

VERTICAL SECTION PLOT - STATION DATA

VERTICAL SUMMARY HISTOGRAM PLOT

VERTICAL TEMPERATURE GRADIENTS

WIND STRESS

PARAMETRIC MAP

POINT GENERATOR FOR DISTANCE-AZIMUTH IBM 7074

POINT GENERATOR FOR MAP PROJECTIONS

CHLOROPHYLL AND PRODUCTIVITY

VELOCITY, HORIZ. EODY COEFFIFIENTS

MULTIVARIATE NON-LINEAR REGRESSION

OCEANOGRAPHIC DATA COMPUTATION

SEDIMENT DATA

SEISMIC SLOPING LAYER

FOURIER ANALYSIS

POWER SPECTRUM ANALYSIS

TWO-DIMENSIONAL AUTOCORRELATION

ACOUSTIC RAY TRACING

PROJECT COD LIVER

DIGITAL POWER SPECTRUM ANALYSIS

LONG. STRENGTH OF SHIP HULL

PARTIAL AND ORDINARY COHERENCE
IBM 7074

IBM 7074

I BM 7074

IBM 7074

IBM 7074

IBM 7074

IBM 7074

IBM 7074

IBM 7074

I BM 7074

IBM 7074

IBM 7074

IBM 7074

IBM 7074

IBM 7074

IBM 7074

IBM 7074

IBM 7074

IBM 7074

I BM 7074

IBM 7074

IBM 7074

I BM 7074

IBM 7074

I BM 7074

IBM 7074

I BM 7074

IBM 7074

IBM 7074

IBM 7074

IBM 7074

IBM 7074

IBM 7074

IBM 7074

IBM 7074

IBM 7074

IBM 7074

IBM 7074

IBM 7074

IBM 7074

IBM 7074

I BM 7074

IBM 7074

IBM 7074

I BM 7074

IBM 7074

IBM 709

IBM 709

IBM 709

IBM 709

IBM 709

IBM 709

IBM 7090

IBM 7090

IBM 7090

IBM 7090

IBM 7090

IBM 7090

IBM 7090

IBM 7090
IBM 7074

IBM 7074

IBM 7074

IBM 7074
FORTRAN

FURTRAN

FORTRAN

FURTRAN

FURTRAN

FURTRAN

FORTRAN

FORTRAN

FORTRAN

FORTRAN

FURTRAN

FORTRAN

FORTRAN

FORTRAN

FÜRTRAN

FORTRAN

FORTRAN

FORTRAN

FURTRAN

FORTRAN

FORTRAN

FORTRAN

FORTRAN

FURTRAN

FORTRAN

FORTRAN

FORTRAN

FORTRAN

FORTRAN

FORTRAN

FORTRAN

FORTRAN

FURTRAN

FORTRAN

FORTRAN

FORTRAN

FORTRAN

FORTRAN

FORTRAN

FORTRAN

FORTRAN

FURTRAN

FORTRAN

FORTRAN

FORTRAN

FURTRAN

FORTRAN

FURTRAN

FORTRAN

FURTRAN

FORTRAN

FORTRAN

FORTRAN I

FORTRAN I

FORTRAN I I

FORTRAN

FORTRAN

FURTRAN I

FORTRAN II

FORTRAN II

FORTRAN II

FORTRAN

FORTRAN

FORTRAN

FURTRAN I

FORTRAN II

AND MAP

FORTRAN IV 48

FURTRAN IV 110

FORTRAN IV 49 


\section{SAVED (BLAST TEST DATA REDUCTION)}

\begin{tabular}{|c|c|c|c|c|}
\hline I BM & 7090 & $\begin{array}{l}\text { AND MAP } \\
\text { FORTRAN } \\
\text { AND MAP }\end{array}$ & I V & 49 \\
\hline$B M$ & 7090 & FURTRAN & IV & 49 \\
\hline I BM & 7090 & $\begin{array}{l}\text { AND MAP } \\
\text { MAD }\end{array}$ & & 81 \\
\hline $8 M$ & 7090 & MAD & & 93 \\
\hline I BM & 7090 & MAD & & 65 \\
\hline BM & 7090 & MAD & & 65 \\
\hline I BM & 7090 & MAD & & 47 \\
\hline I BM & 7090 & MAD & & 68 \\
\hline I BM & 7090 & MAD & & 104 \\
\hline I BM 7 & $1090 / 9$ & 4FORTRAN & IV & 33 \\
\hline IBM] & $1090 / 9$ & 4FORTRAN, & FAP & 46 \\
\hline I BM 7 & $1090 / 9$ & 4FORTRAN & I V & 104 \\
\hline IBM7 & $1090 / 9$ & 4FORTRAN & IV & 55 \\
\hline IBM 7 & $1090 / 9$ & 4FORTRAN & IV & 34 \\
\hline IBM 7 & $090 / 9$ & 4FORTRAN & I $V$ & 75 \\
\hline IBM] & $1090 / 9$ & 4FORTRAN & IV & 109 \\
\hline I BM 7 & $1090 / 9$ & 4 FORTRAN & I V & 109 \\
\hline $8 M 7$ & $1090 / 9$ & 4 FORTRAN & IV & 110 \\
\hline $8 M 7$ & $1090 / 9$ & 4FORTRAN & IV & 111 \\
\hline I BM & 7094 & FORTRAN & 50. & 110 \\
\hline I BM & 7094 & FORTRAN & I I & 12 \\
\hline I BM & 7094 & FORTRAN & I I & 71 \\
\hline I BM & 7094 & FORTRAN & I I & 71 \\
\hline I BM & 7094 & FORTRAN & II & 71 \\
\hline I BM & 7094 & FORTRAN & I I & 90 \\
\hline$B M$ & 7094 & FORTRAN & II & 70 \\
\hline$B M$ & 7094 & FORTRAN & II & 105 \\
\hline$B M$ & 7094 & FORTRAN & I I & 12 \\
\hline$B M$ & 7094 & FURTRAN & I I & 26 \\
\hline$B M$ & 7094 & FORTRAN & & 87 \\
\hline
\end{tabular}

STATISTICAL AND PEAK-TO-PEAK ANAL.

AVG. TEMPERATURES IN WATER COLUMN

DYNAMIC HEIGHT AND CURRENT DYNAMICS

GENERAL MAP PROJECTION

MAP PROJECTION DISTORTIONS

TREND MAP, WITH RESIDUALS

WIND CURRENTS

THEORETICAL RADIAL TIDAL FORCE

SIMULATION OF MARINE SEDIMENTATION

CALCULATE AND PLOT TIME-TREND CURVES

ASTRONOMICAL TIDE PREDICTION

Q-MODE CLUSTER ANALYSIS

VECTOR TREND ANAL. DIRECTIONAL DATA

SEA ICE STUDIES

WAVE FORCE DISTRIBUTION

WAVE FORCES AND MOMENTS

REFRACTION OF WAVES

SIMULATION OF WIND-GENERATED WAVES

WAVEIN AND DIFRAK

CHLORINITY - SALINITY

CONTINUOUS LINE SOURCE

CONTINUOUS SOURCE PER UNIT DEPTH

CONTINUOUS SOURCE, WITH COOLING TERM

DENSITY - THERMOSTERIC ANOMALY

LATERAL RELATIVE DISTRIBUTION

SURFACE WAVE RAYS

TOTAL CO(2)

MAGNETIC ANOMALIES AND GRADIENTS

OCEANOGRAPHIC DATA PROGRAM F

SYNOPTIC PROGRAM

PROFIL (TSUNAMI PROFILES)

SIMULATION OF MARINE SEDIMENTATION

OPTIMIZATION OF VTE WATER PLANTS

S.T.D. CORRECTION

IBM $7094-I$ IFURTRAN I I 18,90

17040 DCS

IBM 7094 FORTRAN IV 107

IBM 7094 FURTRAN IV 33

IBM 7094 FURTRAN IV 12

IBM 7094 FORTRAN IV 19

TIME TERM, SEISMIC REFRACTION INTERP. IBM 7094 FURTRAN IV 27

CONDU (THERMAL CONDUCTIVITY)

BKGEOL (SEDIMENT STATISTICS)

IBM7094-I IFURTRAN IV

17040 DCS

CONCENTRATIONS PER SQUARE METER

IBM7094-I IFORTRAN IV 31

PHYTOPLANKTON NUMBERS, ETC.

SDGVEL (SOUNDING CORRECTION)

SEDIMENT GRANULOMETRIC ANALYSIS

SYNOPTIC PROGRAM

CURRENT

BOMM (TIME SERIES)

SPECIFIC CONDUCTIVITY

WAVE STATISTICS

BLACKY (TIME SERIES ANALYSIS)

CURRENT

OBJECTIVE THERMOCLINE ANALYSIS

CURRENT METER DYNAMICS

INVENTORY PLOT

SUBROUTINE 'MAP'

DETRND, ETC. (SPECTRA SUBROUTINES)

LENG 1 (WAVE LENGTH AND SPEED)

PROFILE

PROF 1 (WATER ELEV. OVER WAVE PERIOD)

REFL 1 (REFLECTED WAVE)

UMAXI, ETC. (MAX. FLOW VELOC.)

17040 DCS

IBM7094-IIFURTRAN IV 07

17040 DCS

IBM7094-I IFORTRAN IV 07

17040 DCS

IBM7094-I IFORTRAN IV 102

17040 DCS

IBM7094-I IFORTRAN IV 32

17040 DCS

I BM7094-I IFORTRAN II 18,90

17040 DCS

IBM OS/36OFORTRAN IV 56

IBM OS/36OFORTRAN 52

IBM OS/36OFORTRAN 11

IBM OS/36OFORTRAN IV 110

IBM OS/36OFURTRAN IV 49

IBM OS/36OFORTRAN IV 56

IBM OS/36OFURTRAN IV-H 75

IBM OS/36OMAC 72

IBM 360/4OFORTRAN IV 41

IBM 360/4OFORTRAN IV 63

IBM $360 / 4$ OFORTRAN IV 48

IBM 360/4OFURTRAN IV 107

IBM $360 / 4$ OFORTRAN IV 108

IBM 360/4OFURTRAN IV 108

IBM 360/4OFORTRAN IV 108

IBM $360 / 40 F U R T R A N$ IV 109 
UOFT 1, ETC. (FLOW VELOCITIES) GRAPHIC SYSTEM FOR CURVE FITTING RAYTR (RAY-TRACING)

SEICHE ANALYSIS

\section{AZIZ (THERMOMETRIC DEPTH)}

CARDS

DELINT IDELTA CALC AND INTERPOLATION

DEPTHS

HE I GHT

HYDRO

INTEST

LINT (LINEAR INTERPOLATION)

RDTHRM (READ THERMOMETER DATA)

SI GMA

SI GMAD

SI GMAT

TEMP

TSPLOT

UTEMP (UNPROTECTED THERMOMETER)

AOU, ISAOU (CALC. OF OXYGEN, ETC.) GDNP, GRAD (CALC. OF GRADIENTS)

GVPA, VPA (CALC. OF CURRENTS)

ISOS, OXOS, PHOS (I SENTROPIC PLOT)

LENGTH-WEIGHT FREQUENCY

LONG WAVE RADIATION

OCEANOGRAPHIC REPORT PREPARATION

OCEANOGRAPHIC SUMMARY (NOS. $1,2,3$ )

REVERSING THERMOMETER CORRECTION

TSIP, THOX, THOT (PLOT TIME HISTORY)

FLOW METER PLOTS

GENERAL MERCATOR PLOT

HORIZONTAL SECTIONS

IN SITU OCEANOGRAPHIC DATA

INTERPOLATION

MERCATOR STATION PLOT

OXYGEN, PHOSPHATE, DENSITY PLOTS

TEMPERATURE-SALINITY CURVES

OCEANS II I

THERMOCHECK I I - TEMP. CORRECTION WATER CHEMISTRY

PERCENTAGE SATURATION OF OXYGEN

ASTRONOMIC POSITION

PROFILE CARD-TO-TAPE FOR GEOPAC

TALWANI 2-D GRAVITY

GENERAL REGRESSION

WAVES GENERATED BY TURBULENT WIND

Q-MODE CLUSTER ANALYSIS

SIMULATION OF DELTAIC SEDIMENTATION
IBM 360/4OFORTRAN IV 108

IBM 360/40 (NOT GIVEN) 45

IBM 360/44FORTRAN IV 97

IBM 360/50ALGOL, $\quad 107$

FORTRAN II

IBM 360/5OFURTRAN IV-E 88

IBM 360/50FORTRAN IV-E 22

88

22

87

19

88

88

22

89

89

87

19

44

19

10

76

69

40

06

25

91

79

20

41

72

40

40

85

86

40

39

39

86

17

09

10

59

26

26

45

IBM 360/67FORTRAN $\quad 106$

IBM 360/67FORTRAN IV 55

IBM 360/67FURTRAN IV-H 34

\section{XEROX DATA SYSTEMS}

ATG (ADIABATIC TEMPERATURE GRADIENT BETA-MODEL WITH WHITE FORCING

DATA

DSTABF (STABILITY FREQUENCY)

HISTO (HISTOGRAM PLOT)

HYLOG (HYDRO. STA. DATA REDUCTION)

LISPLO (LIST AND PLOT)

NUSPEC (SPECTRUM ESTIMATION)

OCCOMP (OCEANOGRAPHIC COMPUTE)

POTEMP (POTENTIAL TEMPERATURE)

PRESS

PROVEC (PROGRESSIVE VECTORS)

SCRUB (DATA EDIT AND CORRECT)

S I GMAT

SONVEL (SOUND VELOCITY)

SPVOL

STATS (STATISTICAL QUANTITIES)
SDS SIGMATFORTRAN IV-H SDS SIGMATFURTRAN IV-H SDS SIGMATFORTRAN IV-H SDS SIGMATFORTRAN IV-H SDS SIGMATFORTRAN IV-H SDS SIGMATFORTRAN IV-H SDS SIGMATFORTRAN IV $V H$ SDS SIGMATFORTRAN I $\mathrm{V}-\mathrm{H}$ SDS SIGMATFURTRAN I $V-H$ SDS SIGMATFORTRAN IV-H SDS SIGMATFORTRAN IV-H SOS SIGMATFORTRAN I $V-H$ SDS SIGMATFORTRAN IV-H 23 SDS SIGMATFORTRAN IV-H 91 SDS SIGMATFORTRAN IV-H 103 SDS SIGMATFORTRAN IV-H 92 SDS SIGMA7FORTRAN IV-H 57 
SVANOM (SPECIFIC VOLUME ANOMALY)

THISTO (TWO-DIMEN. FREQ. DISTRIB•)

THRCL (THERMOMETER (ALIBRATION)

VECTAV (VECTOR AVERAGES)

VEL (GEOSTROPHIC VELOCITY)

VTR (VOLUME TRANSPORT)

UNIVAC

OPTIMUM TRACK SHIP ROUTING

NEWFIT

PATTERN FUNCTION CALCULATIONS

RAY SORT

RAYMOR

SONAR IN REFRACTIVE WATER

SPECTRAL ANALYSIS OF TIME SERIES
SDS SIGMA7FORTRAN IV-H 92

SDS SIGMATFURTRAN IV-H 74

SDS SIGMA7FURTRAN I V-H 20

SDS SIGMATFURTRAN IV-H 74

SDS SIGMATFORTRAN IV-H 73

SDS SIGMATFORTRAN IV-H 73

UNIVACI107FORTRAN IV 106 UNIVACIIOBFORTRAN IV 95 UNIVACIIOSFORTRAN IV 95 UNIVACIIOBFORTRAN IV 95 UNIVACI108FORTRAN V 95 UNIVACIIOBFORTRAN IV 94 UNIVACIIOBFURTRAN IV 50

OTHERS

AN/UYK-1 SOUND VELOCITY BIOLOGICAL STATION FILE STATION DATA (ATLAS) Q FACTORS

CROSS-ASSOCIATION OF SEQUENCES

DEEP (S.T.D. DIGITIZING)

WET (S.T.D. DATA PROCESSING)

CHLOROPHYLL CALCULATIONS

DELTA-ALPHA AND SIGMA-T

HARMONIC ANALYSIS

TIDAL PREDICTION

VELOCITY OF SOUND

THERMOMETER CORRECTIONS

TIDAL ANALYSIS AND PREDICTION

PREDICTION OF HOURLY TIDE

POWER SPECTRUM ANALYSIS

OPTIMUM TRACK SHIP ROUTING

$\begin{array}{llr}\text { AN/UYK-1 } & \text { LOGANDS } & 103 \\ \text { ATLAS I } & \text { EMA } & 112 \\ \text { ATLAS } 1 & \text { EMA } & 83 \\ \text { ATLAS I } & \text { FORTRAN V } & 15 \\ \text { ELLIOTT803ALGOL 60 } & 54 \\ \text { HP 2115A } & \text { FORTRAN } & 16 \\ \text { HP 2115A } & \text { FORTRAN } & 84 \\ \text { ICT 1301 } & \text { MAC } & 07 \\ \text { ICT 1301 } & \text { MAC } & 93 \\ \text { ICT 1301 } & \text { MAC } & 51 \\ \text { ICT 1301 } & \text { MAC } & 105 \\ \text { ICT 1301 } & \text { MAC } & 103 \\ \text { MERCURY } & \text { CHLF 3/4 } & 15 \\ \text { MERCURY } & \text { CHLF 3/4 } & 104 \\ \text { MERCURY } & \text { NOT GIVEN } & 105 \\ \text { PB-250 } & \text { BASIC } & 51 \\ \text { PB-440 } & \text { MACHINE } & 106\end{array}$


This is a source sheet for the NODC publication Computer Programs in Oceanography. Please use a separate form for each program.

GENERAL INFORMATION

Title of program

Person to be contacted for further information concerning this program (NODC will refer all inquiries to this person).

Name

Institution

Address Telephone Number

Are you willing to make the source program available to the oceanographic community?

If yes, please forward a documented copy of the program to the NODC. Whenever the NODC acts as an intermediary in the transmittal of this program, you will be given full credit.

\section{PROGRAM DESCRIPTION}

Purpose of program

Input to program (type and format of data)

Output from program (form and content)

General procedure followed (i.e., mathematical methods or statistical techniques used, approximations, etc.)

Source language of program

Documentation available

HARDWARE REQUIREMENTS

Core storage necessary (number of characters or words, please specify)

Additional storage requirements

Number of tape units used

Special input-output requirements

Other requirements

Computer for which program has been written 


